Founder: Federal Scientific Center for Medical and Preventive Health Risk Management Technologies Federal Service for Surveillance on Consumer Rights Protection and Human Wellbeing

\section{Contact Information:}

82 Monastyrskaya St.,

Perm, 614045, Russia

Tel/Fax: + 7 (342) 237-25-34

E-mail: journal@ffrisk.ru

Site: journal.fcrisk.ru/eng

Editor and corrector-M.N. Afanaseva Technical Editor - A.A. Nizhegorodova Translators - N.V. Dubrovskaya

All rights reserved. No part of this publication may be stored in the computer's memory or reproduced in any way without the prior written permission of the publisher.

The publication 30.09.2019.

Format $90 \times 60 / 8$.

Order No. 160/2019.

Edition is 500 copies.

The price is free.

The Journal is registered by The Federal Service For Supervision Of Communications, Information Technology, And Mass Media (Roscomnadzor). Register certificate СМИ - ПИ N. ФС 77-52552 issued on January 21, 2013

Address of the publisher and printing house: 29 Komsomolsky ave., Perm, 614990, Russia, tel.: +7 (342) 219-80-33

Printed by the Publishing House of Perm National Research Polytechnic University (29 Komsomolsky ave., Perm, 614990, Russia, tel.: +7 (342) 219-80-33)

\section{Subscription number: catalog "Russian Post" annual subscription - 04153 semi-annual subscription - 83927}

ISSN (Print) 2308-1155

ISSN (Online) 2308-1163

ISSN (Eng-online) 2542-2308

The edition is granted the financial support by the Perm Regional Ministry for Educational and Science

\section{HEALTH RISK ANALYSIS}

Theoretical and practical journal. Start of publication: 2013.

EDITORIAL BOARD

$$
4 \text { issues per year }
$$

G.G. Onishchenko - Editor in Chief, Fellow of the Russian Academy of Sciences, DSc, Professor (Moscow, Russia)

N.V. Zaitseva - Deputy Chief Editor, Fellow of the Russian Academy of Sciences, DSc, Professor (Perm, Russia)

I.V. May - Executive Secretary, DSc, Professor (Perm, Russia)

\section{EDITORS}

S.L. Avaliani - DSc, Professor (Moscow, Russia)

A.B. Bakirov - DSc, Professor (Ufa, Russia)

E.N. Belyaev - corresponding member of RAS, DSc, Professor (Moscow, Russia)

V.M. Boev - DSc, Professor, (Orenburg, Russia)

I.V. Bragina-DSc (Moscow, Russia)

R.V. Buzinov - DSc (Arkhangelsk, Russia)

I.V. Bukhtiyarov - corresponding member of RAS, DSc,

Professor (Moscow, Russia)

V.B. Gurvich - DSc (Ekaterinburg, Russia)

I. Dardynskaia - DSc, Professor (Chicago, USA)

MA. Zemlyanova - DSc (Perm, Russia)

U.I. Kenesariev - DSc, Professor, corresponding member of the Academy of Medical Sciences of Kazakstan (Almaty, Kazakstan)

T. Cronberg - DSc in Ec., DSc in Tec., Member of the

European Parliament from Finland. (Ruveslahti, Finland)

S.V. Kuz'min - DSc, Professor (Ekaterinburg, Russia)

V.V. Kutyrev - Fellow of the Russian Academy of Sciences, DSc, Professor (Saratov, Russia)

V.R. Kuchma - corresponding member of RAS, DSc, Professor, (Moscow, Russia)

A.-M. Landtblom - MD PhD, Professor (Uppsala, Sweden)

Le Thi Hong Hao - Assoc., Professor (Hanoi, Vietnam)

A.G. Malysheva - DSc, Professor (Moscow, Russia).

A.V. Mel'tser - DSc, Professor (St.-Petersburg, Russia)

A.Ya. Perevalov - DSc, Professor (Perm, Russia)

Y.P. Pivovarov - Fellow of RAS, DSc, Professor (Moscow, Russia)

A.Yu. Popova - DSc, Professor (Moscow, Russia)

J. Reis - AEA Physiology, MD (Strasbourge, France)

V.N. Rakitskiy - Fellow of RAS, DSc, Professor, (Moscow, Russia)

Y.A. Revazova - DSc, Professor (Moscow, Russia)

V.S. Repin - DSc, Professor (St.-Petersburg, Russia)

A.V. Reshetnikov - Fellow of RAS, DSc, Professor (Moscow, Russia)

S.I. Savelyev - DSc, Professor (Lipetsk, Russia)

P. Spencer - PhD, FRCPath Professor Department of neurology

(Portland, USA)

V.F. Spirin - DSc, Professor (Saratov, Russia) Director

A.Tsakalof - Professor of Medical Chemistry (Larissa, Greece)

V.A. Tutelyan - Fellow ofRAS, DSc, Professor (Moscow, Russia)

H.H. Hamidulina - DSc, professor, (Moscow, Russia)

S.A. Hotimchenko - DSc, professor (Moscow, Russia)

L.M. Shevchuk - PhD (Minsk, Belarus)

N.V. Shestopalov - DSc, Professor (Moscow, Russia)

P.Z. Shur - DSc, professor (Perm, Russia)
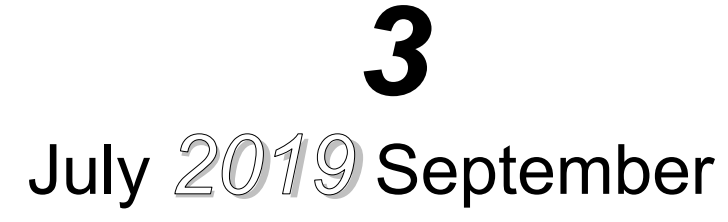


\section{PREVENTIVE HEALTHCARE:} TOPICAL ISSUES OF HEALTH RISK ANALYSIS

N.V. Zaitseva, I.V. May, S.V. Kleyn, D.V. Goryaev METHODICAL APPROACHES TO SELECTING OBSERVATION POINTS AND PROGRAMS FOR OBSERVATION OVER AMBIENT AIR QUALITY WITHIN SOCIAL AND HYGIENIC MONITORING AND “PURE AIR" FEDERAL PROJECT

\section{HEALTH RISK ANALYSIS IN HYGIENE}

A.N. Deryabin, T.N. Unguryanu, R.V. Buzinov POPULATION HEALTH RISK CAUSED BY EXPOSURE TO CHEMICALS IN SOILS

E.P. Tarutta, O.V. Proskurina, N.A. Tarasova, G.A. Markosyan ANALYSIS OF RISK FACTORS THAT CAUSE MYOPIA IN PRE-SCHOOL CHILDREN AND PRIMARY SCHOOL STUDENTS

K.S. Golokhvast, K.Yu. Kirichenko, P.F. Kiku, N.V. Efimova, M.F. Savchenkov, I.A. Vakhnyuk, D.Yu. Kosyanov, S.A. Medvedev, V.P. Soparev, V.A. Drozd NANO- AND MICRO-PARTICLES CONCENTRATIONS

IN WORKING AREA AIR AT GALVANIC PRODUCTION: PILOT RESEARCH

D.O. Gorbachev, O.V. Sazonova, L.M. Borodina, M.Y. Gavryushin ANALYZING HEALTH RISKS FOR EMPLOYABLE POPULATION CAUSED BY FOOD PRODUCTS CONTAMINATION (EXPERIENCE GAINED IN SAMARA REGION)

I.B. Perova, K.I. Eller, E.V. Tumol'skaya SCREENING RESULTS FOR NON-DECLARED SYNTHETIC PHOSPHODIESTERASE-5 INHIBITORS BEING ADDED DIETARY SUPPLEMENTS OF PLANT ORIGIN

I. Boström, T. Riise, K. Björnevik, K.-M. Myhr, M. Pugliatti, C. Wolfson, A.-M. Landtblom ENVIRONMENTAL FACTORS IN MULTIPLE SCLEROSIS, FOCUSING EXPOSURE TO ORGANIC SOLVENTS

\section{HEALTH RISK ANALYSIS IN EPIDEMIOLOGY} ASSESSING POTENTIAL THREAT OF HIV-INFECTION SPREAD IN RUSSIA BY MIGRANTS FROM ASIAN AND AFRICAN COUNTRIES

E.G. Simonova, A.A. Shabeikin, S.R. Raichich, M.N. Loktionova, S.A. Saburova, M.A. Patyashina, V.I. Ladnyi, A.M. Gulyukin GEOINFORMATION TECHNOLOGIES FOR ASSESSING EPIZOOTOLOGIC AND EPIDEMIOLOGIC SITUATION WITH ANTHRAX

MEDICAL AND BIOLOGICAL ASPECTS RELATED TO ASSESSMENT OF IMPACTS EXERTED BY RISK FACTORS

N.V. Shartova, D.A. Shaposhnikov, P.I. Konstantinov, B.A. Revich UNIVERSAL THERMAL CLIMATE INDEX (UTCI) APPLIED TO DETERMINE THRESHOLDS FOR TEMPERATURE-RELATED MORTALIT
ПРОФИЛАКТИЧЕСКАЯ МЕДИЦИНА: АКТУАЛЬНЫЕ АСПЕКТЫ АНАЛИЗА РИСКА ЗДОРОВЬЮ

4 Н.В. Зайчева, И.В. Май, С.В. Клейн, Д.В. Горяев МЕТОДИЧЕСКИЕ ПОДХОДЫ К ВЫБОРУ ТОЧЕК И ПРОГРАММ НАБЛЮДЕНИЯ ЗА КАЧЕСТВОМ АТМОСФЕРНОГО ВОЗДУХА В РАМКАХ СОЦИАЛЬНОГИГИЕНИЧЕСКОГО МОНИТОРИНГА ДЛЯ ЗАДАЧ ФЕДЕРАЛЬНОГО ПРОЕКТА «ЧИСТЫЙ ВОЗДУХ»

\section{АНАЛИЗ РИСКА ЗДОРОВЬЮ В ГИГИЕНЕ}

18 А.Н. Дерябин, Т.Н. Унгуряну, Р.В. Бузинов РИСК ЗДОРОВЬЮ НАСЕЛЕНИЯ, СВЯЗАННЫЙ С ЭКСПОЗИЦИЕЙ ХИМИЧЕСКИХ ВЕЩЕСТВ ПОЧВЫ

26 Е.П. Тарутта, О.В. Проскурина, Н.А. Тарасова, Г.А. Маркосян АНАЛИЗ ФАКТОРОВ РИСКА РАЗВИТИЯ БЛИЗОРУКОСТИ В ДОШКОЛЬНОМ И РАННЕМ ШКОЛЬНОМ ВОЗРАСТЕ

34 К.С. Голохваст, К.Ю. Кириченко, П.Ф. Кику, Н.В. Ефимова, М.Ф. Савченков, И.А. Вахнюк, Д.Ю. Косьянов, С.А. Медведев, В.П. Сопарев, В.А. Дрозд СОДЕРЖАНИЕ НАНО- И МИКРОЧАСТИЦ В ВОЗДУХЕ РАБОЧЕЙ ЗОНЫ ГАЛЬВАНИЧЕСКОГО ПРОИЗВОДСТВА: ПИЛОТНОЕ ИССЛЕДОВАНИЕ

42 Д.О. Горбачев, О.В. Сазонова, Л.М. Бородина, М.Ю. Гаврюшин АНАЛИЗ РИСКА ЗДОРОВЬЮ ТРУДОСПОСОБНОГО НАСЕЛЕНИЯ, ОБУСЛОВЛЕННОГО КОНТАМИНАЦИЕЙ ПИЩЕВЫХ ПРОДУКТОВ (ОПЫТ САМАРСКОЙ ОБЛАСТИ)

50 И.Б. Перова, К.И. Эллер, Е.В. Тумольская РЕЗУЛЬТАТЫ МОНИТОРИНГА НЕДЕКЛАРИРОВАННОГО ДОБАВЛЕНИЯ СИНТЕТИЧЕСКИХ ИНГИБИТОРОВ ФОСФОДИЭСТЕРАЗЫ-5 В БАД К ПИЩЕ РАСТИТЕЛЬНОГО ПРОИСХОЖДЕНИЯ

60 И. Бострум, Т. Ризе, К. Бьёрневик, К.-М. Мур, М. Паглиатти, К. Вольфзон, А.-М. Ландблом ВНЕШНИЕ ФАКТОРЫ РИСКА РАССЕЯННОГО СКЛЕРОЗА И ВОЗДЕЙСТВИЕ ОРГАНИЧЕСКИХ РАСТВОРИТЕЛЕЙ КАК ОДИН ИЗ НИХ

\section{АНАЛИЗ РИСКА ЗДОРОВЬЮ В ЭПИДЕМИОЛОГИИ}

66 Р.В. Дмитриев ОЦЕНКА ПОТЕНЦИАЛЬНОЙ УГРОЗЫ РАСПРОСТРАНЕНИЯ ВИЧ-ИНФЕКЦИИ В РОССИИ МИГРАНТАМИ ИЗ СТРАН АФРИКИ И АЗИИ

74 Е.Г. Симонова, А.А. Шабейкин, С.Р. Раичич, М.Н. Локтионова, С.А. Сабурова, М.А. Патяшина, В.И. Ладный, А.М. Гулюкин ПРИМЕНЕНИЕ ГЕОИНФОРМАЦИОННЫХ ТЕХНОЛОГИЙ ДЛЯ ОЦЕНКИ ЭПИЗООТОЛОГИЧЕСКОЙ И ЭПИДЕМИОЛОГИЧЕСКОЙ СИТУАЦИИ ПО СИБИРСКОЙ ЯЗВЕ

\section{МЕДИКО-БИОЛОГИЧЕСКИЕ АСПЕКТЫ ОЦЕНКИ ВОЗДЕЙСТВИЯ ФАКТОРОВ РИСКА}

83 Н.В. Шартова, Д.А. Шапошников,

П.И. Константинов, Б.А. Ревич

ОПРЕДЕЛЕНИЕ ПОРОГОВ ТЕМПЕРАТУРНО-ЗАВИСИМОЙ СМЕРТНОСТИ НА ОСНОВЕ УНИВЕРСАЛЬНОГО ИНДЕКСА ТЕПЛОВОГО КОМФОРТА - UТСІ 
S.Yu. Franovskii, V.V. Turbinskii, E.I. Oks, S.B. Bortnikova ELEMENTAL MARKERS OF EXPOSURE UNDER COMBINED ORAL INTRODUCTION OF CHEMICAL MIXTURES WITH PREVALENT ANTIMONY AND ARSENIC INTO WHITE WISTAR RATS

I.A. Umnyagina, T.V. Blinova, L.A. Strakhova, V.V. Troshin, S.A. Kolesov, O.V. Sherstobitova OXIDATIVE STRESS AND ANTIOXIDANT PROTECTION IN PEOPLE OF VARIOUS AGE UNDER CONTACT WITH ADVERSE OCCUPATIONAL FACTORS

A.V. Kharin, I.V. Aver yanova, S.I. Vdovenko ASSESSING MORPHOFUNCTIONAL STATE OF MICROCIRCULATION CHANNEL IN SMOKING YOUNG MALES

Vu Thi Trang, Le Hoang Duc, Nguyen Hoai Thu, Le Thi Hong Hao, Nguyen Xuan Trung MULTISEPARATION OF ANTHOCYANINS AND ANTHOCYANIDINS BY HIGH PERFORMANCE

LIQUID CHROMATOGRAPHY COMBINED WITH RESPONSE SURFACE METHODOLOGY

TOXICOLOGICAL RESEARCH IN HEALTH RISK ASSESSMENT

A.V. Voronkov, D.I. Pozdnyakov, V.M. Rukovitsyna, E.T. Oganesyan, M.P. Voronkova CARDIOTROPIC PROPERTIES OF CHROMONE-3ALDEHYDE DERIVATIVES UNDER AN EXPERIMENTAL CARDIAC INFARCTION COMPLICATED WITH HYPERCHOLESTEROLEMIA

HEALTH RISK ANALYSIS: SOCIAL, ECONOMIC FACTORS

O.Yu. Milushkina, N.A. Skoblina, S.V. Markelova, A.A. Tatarinchik, N.A. Bokareva, D.M. Fedotov ASSESSING HEALTH RISKS FOR SCHOOLCHILDREN AND STUDENTS CAUSED BY EXPOSURE

TO EDUCATIONAL AND ENTERTAINING INFORMATION TECHNOLOGIES

HEALTH RISK ANALYSIS RELATED TO ORGANIZATIONAL TASKS IN PUBLIC HEALTHCARE

A.V. Bogomolov, S.S. Chikova, T.V. Zueva INFORMATION TECHNOLOGIES FOR DATA COLLECTION AND PROCESSING WHEN ESTABLISHING DETERMINANTS OF EPIDEMIC PROCESSES

R.S. Rakhmanov, N.N. Potekhina, A.V. Tarasov, I.N. Koldunov RISK ASSESSMENT FOR INCIDENCE WITH COMMUNITY-ACQUIRED PNEUMONIA IN ORGANIZED COMMUNITIES AMONG THIER MEMBERS ADAPTING TO TRAINING AND ACCLIMATIZATION

ANALYTICAL REVIEWS

S.I. Dolomatov, T.P. Sataeva, W. Zukow MODERN ASPECTS OF REGULATORY, PATHOPHYSIOLOGICAL AND TOXIC EFFECTS OF COBALT IONS DURING ORAL INTAKE IN THE HUMAN BODY

NEW LEGAL, REGULATORY AND METHODOLOGICAL DOCUMENTS ISSUED IN THE RF IN THE SPHERE OF HEALTH RISK
94 С.Ю. Франовский, В.В. Турбинский, Е.И. Окс, С.Б. Бортникова ЭЛЕМЕНТНЫЕ МАРКЕРЫ ЭКСПОЗИЦИИ ПРИ КОМБИНИРОВАННОМ ПЕРОРАЛЬНОМ ДЕЙСТВИИ НА ОРГАНИЗМ БЕЛЫХ КРЫС ЛИНИИ ВИСТАР ХИМИЧЕСКИХ СМЕСЕЙ С ПРЕОБЛАДАНИЕМ СУРЬМЫ И МЫШЬЯКА

104 И.А. Умнягина, Т.В. Блинова, Л.А. Страхова, В.В. Трошин, С.А. Колесов, О.В. Шерстобитова ОКИСЛИТЕЛЬНЫЙ СТРЕСС И АНТИОКСИДАНТНАЯ ЗАЩИТА У ЛИЦ РАЗНОГО ВОЗРАСТА, ИМЕЮЩИХ КОНТАКТ С ВРЕДНЫМИ ПРОИЗВОДСТВЕННЫМИ ФАКТОРАМИ

112 А.В. Харин, И.В. Аверьянова, С.И. Вдовенко ОЦЕНКА МОРФОФУНКЦИОНАЛЬНОГО СОСТОЯНИЯ МИКРОЦИРКУЛЯТОРНОГО РУСЛА У КУРЯЩИХ ЮНОШЕЙ

118 Ву Ти Транг, Ли Хоанг Дук, Нгаен Хай Ти, Ле Ти Хонг Хао, Нгаен Сюан Чанг МУЛЬТИРАЗДЕЛЕНИЕ АНТОЦИАНОВ И АНТОЦИАНИДИНОВ МЕТОДОМ ВЫСОКОЭФФЕКТИВНОЙ ЖИДКОСТНОЙ ХРОМАТОГРАФИИ С ОДНОВРЕМЕННЫМ ПРИМЕНЕНИЕМ МЕТОДА ПОВЕРХНОСТИ ОТКЛИКА

\section{ТОКСИКОЛОГИЧЕСКИЕ ИССЛЕДОВАНИЯ} В ОЦЕНКЕ РИСКА ЗДОРОВЬЮ

128 А.В. Воронков, Д.И. Поздняков, В.М. Руковицина, Э.Т. Оганесян, М.П. Воронкова КАРДИОТРОПНЫЕ СВОЙСТВА ПРОИЗВОДНЫХ ХРОМОН-3-АЛЬДЕГИДА В УСЛОВИЯХ ЭКСПЕРИМЕНТАЛЬНОГО ИНФАРКТА МИОКАРДА, ОСЛОЖНЕННОГО ГИПЕРХОЛЕСТЕРИНЕМИЕЙ

АНАЛИЗ РИСКА ЗДОРОВЬЮ: СОЦИАЛЬНЫЕ, ЭКОНОМИЧЕСКИЕ ФАКТОРЫ

135 О.Ю. Милушкина, Н.А. Скоблина, С.В. Маркелова, А.А. Татаринчик, Н.А. Бокарева, Д.М. Федотов ОЦЕНКА РИСКОВ ЗДОРОВЬЮ ШКОЛЬНИКОВ И СТУДЕНТОВ ПРИ ВОЗДЕЙСТВИИ ОБУЧАЮЩИХ И ДОСУГОВЫХ ИНФОРМАЦИОННОКОММУНИКАЦИОННЫХ ТЕХНОЛОГИЙ

АНАЛИЗ РИСКА ЗДОРОВЬЮ В ЗАДАЧАХ ОРГАНИЗАЦИИ ЗДРАВООХРАНЕНИЯ

144 А.В. Богомолов, С.С. Чикова, Т.В. Зуева ИНФОРМАЦИОННЫЕ ТЕХНОЛОГИИ СБОРА И ОБРАБОТКИ ИНФОРМАЦИИ ПРИ УСТАНОВЛЕНИИ ДЕТЕРМИНАНТ ЭПИДЕМИЧЕСКИХ ПРОЦЕССОВ

154 Р.С. Рахманов, Н.Н. Потехина, А.В. Тарасов, И.Н. Колдунов ОЦЕНКА РИСКА ЗАБОЛЕВАЕМОСТИ ВНЕБОЛЬНИЧНОЙ ПНЕВМОНИЕЙ В ОРГАНИЗОВАННЫХ КОЛЛЕКТИВАХ ВЗРОСЛЫХ ПРИ АДАПТАЦИИ К УСЛОВИЯМ ОБУЧЕНИЯ И АККЛИМАТИЗАЦИИ

\section{АНАЛИТИЧЕСКИЕ ОБЗОРЫ}

161 С.И. Доломатов, Т.П. Сатаева, В. Жуков СОВРЕМЕННЫЕ АСПЕКТЫ РЕГУЛЯТОРНЫХ, ПАТОФИЗИОЛОГИЧЕСКИХ И ТОКСИЧЕСКИХ ЭФФЕКТОВ, ВЫЗЫВАЕМЫХ ИОНАМИ КОБАЛЬТА ПРИ ОРАЛЬНОМ ПОСТУПЛЕНИИ В ОРГАНИЗМ ЧЕЛОВЕКА

175 НОВЫЕ ЗАКОНОДАТЕЛЬНЫЕ, НОРМАТИВНЫЕ И МЕТОДИЧЕСКИЕ ДОКУМЕНТЫ РОССИЙСКОЙ ФЕДЕРАЦИИ В СФЕРЕ АНАЛИЗА РИСКА ЗДОРОВЬЮ 
PREVENTIVE HEALTHCARE: TOPICAL ISSUES OF HEALTH RISK ANALYSIS

UDC 504.064:614.7

DOI: $10.21668 /$ health.risk/2019.3.01.eng

\title{
METHODICAL APPROACHES TO SELECTING OBSERVATION POINTS AND PROGRAMS FOR OBSERVATION OVER AMBIENT AIR QUALITY WITHIN SOCIAL AND HYGIENIC MONITORING AND "PURE AIR" FEDERAL PROJECT
}

\author{
N.V. Zaitseva ${ }^{1}$, I.V. May ${ }^{1}$, S.V. Kleyn ${ }^{1}$, D.V. Goryaev ${ }^{2}$ \\ ${ }^{1}$ Federal Scientific Center for Medical and Preventive Health Risk Management Technologies, 82 Monastyrskaya \\ str., Perm, 614004, Russian Federation \\ ${ }^{2}$ Federal Service for Surveillance over Consumer Rights Protection and Human Wellbeing, Krasnoyarsk Region \\ office, 21 Karatanova Str., Krasnoyarsk, 660049, Russian Federation
}

The Federal project entitled "Pure air" is a part of "Ecology", the National project; its primary goal is to achieve a significant improvement in ambient air quality in cities where at present air contamination and population health risks related to it are the most significant. Activities aimed at improving the ecological situation in these cities are provided with the considerable state investment. Results of systemic instrumental measuring that is performed within state systems of ecological and social-hygienic monitoring are considered to be the most informative and reliable database to assess efficiency of air-protecting activities accomplished within the project. Our research goal was to develop and test methodical approaches to substantiating points and programs for observation over ambient air quality within social-hygienic monitoring. The said approaches were to be tested on concrete examples taking into account the existing ecologic monitoring system. We chose the following objects to test our approaches: two cities out of the priority list, namely Krasnoyarsk and Chita. Systemic observations are performed in both cities. There are data on the structure of emissions from all major contamination sources. In Krasnoyarsk there is an aggregated database that contains data on parameters of emission sources; there was no such database in Chita at the moment our research was accomplished. Given the availability of necessary initial data, we suggested algorithms for creating a system of points where observation posts were to be located and for monitoring programs development. We applied health hazards and health risks as our basic criterion for creating an observation system within social-hygienic monitoring. It was shown that data that were collected at ecologic monitoring posts without any changes in their location could be applied to solve tasks related to assessing and predicting health risks as well as analyzing efficiency of accomplished activities provided that research programs were supplemented with parameters that were priority ones as per health hazards and risks. We developed approaches to selecting points and programs for independent research within social-hygienic monitoring. These approaches involve dividing city territories into specific zones as per potential health hazards (when dispersal is not calculated) or health risk levels (when dispersal is calculated); substantiating a list of priority admixtures taking into account carcinogenic and/or non-carcinogenic hazards and risks as well as results of accomplished instrumental measuring and determining parameters of marker (indicator) enterprises with their emissions making the most significant contribution into air contamination.

Key words: ambient air quality, social-hygienic monitoring, observation posts and programs, health risk.

Air quality in industrial cities should years all over the world, including the Russian necessarily conform to hygienic standards; Federation [1-6]. achieving it has been a most significant social, The Federal project "Clean air" which is a ecological, and sanitary-hygienic task for many part of the National project "Ecology" outlines

(C) Zaitseva N.V., May I.V., Kleyn S.V., Goryaev D.V., 2019

Nina V. Zaitseva - Academician of the Russian Academy of Sciences, Doctor of Medical Sciences, Professor, Scientific Director (e-mail: znv@fcrisk.ru; tel.: +7 (342) 237-25-34; ORCID: https://orcid.org/0000-0003-2356-1145).

Irina V. May - Doctor of Biological Sciences, Professor, Deputy Director responsible for research work (e-mail: may@fcrisk.ru; tel.: +7 (342) 237-25-47; ORCID: https://orcid.org/0000-0003-0976-7016).

Svetlana V. Kleyn - Doctor of Medical Science, head of the department of methods for sanitary analysis and monitoring (e-mail: kleyn@fcrisk.ru; tel.: +7 (342) 236-32-64; ORCID: https://orcid.org/0000-0002-2534-5713).

Dmitrii V. Goryaev - Candidate of Medical Sciences, Head of the Administration of the Federal Service on Surveillance for Consumer rights protection and human well-being in Krasnoyarsk region (e-mail: goryaev_dv@24.rospotrebnadzor.ru; tel.: +7(391) 226-89-50; ORCID: http://orcid.org/0000-0001-6450-4599). 
priority territories where air contamination and potential population health risks are an acute problem $^{1}$. These territories are to become research objects where approaches to optimal planning and implementation of air-protecting activities are to be tested; ecological situation is to improve significantly; threats to population health and life that are related to aerogenic environmental factors are to be minimized. Should these approaches be considered efficient, they can be applied in other regions in the country and in long-term planning as well.

The Federal project "Clean air" is aimed at overall $20 \%$ decrease in gross emissions on priority territories. Undoubtedly, this value is in line with potential improvements in ecological and sanitary-epidemiological situation. But still, actual air quality improvement on a specific territory depends not only on a decrease in emission masses but also on spatial location of emission sources, housing, recreational, and other standardized zones, as well as on emission parameters (height, temperature, linear velocity, etc.). Component structure of emissions that are to be reduced is also extremely important.

Instrumental measurements performed within ecological monitoring, social and hygienic monitoring, and industrial control by economic entities themselves provide the most informative and reliable data for assessing efficiency of airprotecting activities accomplished within the project. Each of the above-mentioned monitoring types has its own tasks and procedures for selecting monitoring points and programs. Thus, ecologic monitoring primarily aims at observing over air pollution caused by economic activities and meteorological conditions and at predicting expected changes in air quality over a long-term period $^{2}$. Industrial control is to register whether an economic entity conforms to fixed safety requirements when performing its economic activities or violates them $[7,8]$. And only social and hygienic monitoring (SHM) has a primary goal that is to assess population health, detect any changes in it, and to predict a future situation under exposure to environmental factors ${ }^{3}$. That is, it focuses not on a simple concentration of this or that contaminant (admixture or substance) in the air but on a health parameter related to it.

Given that, air quality assessments within SHM should be oriented at those admixtures that are potentially the most hazardous for human life and health under short-term and/or long-term exposure; are registered in the air on a territory where population reside permanently; create risks that adverse effects on health can summate or enhance (become synergic) under simultaneous exposure to them combined with a whole set of any other admixtures [9-11]. The latter is especially significant for cities with developed industries due to a great list of substances contained in dust and gas air mixtures. Thus, for example, emissions from enterprises located in Nizhnekamsk (Republic of Tatarstan) contain approximately 320 specific substances and groups of admixtures; about 70, in Norilsk (Krasnoyarsk region); more than 60 admixtures, in Gubakha (Perm region); etc. It is also rather difficult to select sampling points as they should be representative taking into account city territories being large and significant number of population living under different exposure.

Therefore, selecting an optimal list of parameters to be measured and places to locate sampling points becomes a serious scientific task.

We should note that the state ecological monitoring system was created as far back as in the 60ties last century and it has a unified clear procedure that determines locations and number of monitoring stations as well as monitoring programs and periods. The procedure is fixed in the "Guide on control over air pollution" and is obeyed by all the structural divisions of the authorized federal body, Federal Service for Hydrometeorology and Environmental Monitoring of Russia (Rosgidromet). According to recommendations fixed by the said document (see section 2.2. "Location and number of monitoring

\footnotetext{
${ }^{1}$ The National project "Ecology" profile (approved by the RF Presidential Council on strategic development and national projects, the report dated December 24, 2018 No. 16). Available at: http://www.consultant.ru/document/cons_doc LAW 316096/ (date of visit August 12, 2019).

2 See section 1 in Guide P 52.04.186-89. Guide on control over air pollution. Moscow, 1991, 693 p.

${ }^{3}$ On sanitary-epidemiologic welfare of the population: the Federal Law issued on March 30, 1999 NO. 52-FZ (last edited on July 26, 2019). - Clause 45.Social and hygienic monitoring. Available at: http://www.consultant.ru/document/cons doc LAW 22481 (date of visit June 14, 2019).

${ }^{4}$ See sections 2.2-2.4 P 52.04.186-89. Guide on control over air pollution. Moscow, 1991, 693 p.
} 
stations") "...stations should be primarily located on housing territories where the most significant pollution can be expected, then, they should be located in an administrative center of a settlement, and on housing territories with different types of housing located there, as well as in parks and recreation zones...". Monitoring programs should include admixtures selected as per air consumption (AC) criteria (see section 2.4 "Determining a list of admixtures that are subject to control") taking into account a hazard category this or that substance may belong to. It is obligatory to determine prevailing and the most widely spread admixtures, namely dust, sulfur dioxide, carbon oxide, and nitrogen dioxide, at basic stations for ecological monitoring. Programs are assumed to provide not less than 200 observations over concentration of each admixture.

A choice on points at which instrumental research is to be accomplished within industrial control is determined by a boundary of a sanitary protection zone and/or the closest housing territory [12-14].

Any unified and clear procedures for selecting monitoring points and creating monitoring programs for air quality control are not fixed within SHM. There is a letter of guidance issued in $2006^{5}$ that determines basic principles for selecting measurement points and these instructions are similar to that given by the Federal Service for Hydrometeorology and Environmental Monitoring of Russia: “...stationary or mobile stations are to be located in places selected on the basis of preliminary examination of ambient air pollution in a settlement with industrial emissions, emissions from motor transport, from communal and other sources and conditions of their dispersion. Stationary and mobile stations are to be located on housing territories with different types of housing ... Location of stations is to be determined taking into account the highest population density and number... location of industrial zones, streets, and motorways... necessary data should be collected and databases created in order to estimate priority contaminants...”. Unfortunately, this letter of guidance doesn't give any recommendations on what should be included into pre- liminary research, or what data should be taken as grounds for assessing priorities.

Yet many researchers are trying to solve tasks related to scientific foundation for points and programs of monitoring over air quality. Since automated programs for calculating emission dispersion were introduced, spatial analysis of concentration fields has become one of the most significant tools for improving a system for selecting monitoring points and admixtures to be controlled $[15,16]$. Dispersion results have become even more relevant since geoinformation systems were implemented into practice $[17,18]$. However in some authors' opinion, dispersion calculations require validation of their results with data obtained from automated systems that provide uninterrupted control over emissions and/or instrumental research [19]; they can't be considered a single foundation for creating monitoring programs [20]. Health risk assessment methodology for assessing risks caused by exposure to chemicals that pollute the environment now covers such safety criteria as reference levels under short-term and chronic exposure, and it has resulted in understanding that monitoring programs can and should be developed taking into account potential threats for people [20-22]. And a mechanism aimed at selecting priorities in this case should be more complicated than a simple calculation of air consumption.

Having realized how complicated this problem was, a lot of researchers now believe it is vital to integrate various monitoring systems. Thus, Roslyakov et al. [23, 24] outlined certain approaches to combining results of industrial automated control over emissions from a thermal power station (TPS) with results obtained via monitoring over ambient air quality in a zone influenced by an emission source and calculated dispersion of emissions from TPS chimney. Darenskikh (2018) pointed out it was vital to create a unified complex approach when organizing state surveillance and industrial control related to ambient air protection [25]. Ochinnikova et al. (2018) stated it was necessary to combine social and hygienic monitoring and sanitaryepidemiologic control in the sphere of ambient air

\footnotetext{
${ }^{5}$ On organizing laboratory control within social and hygienic monitoring activities: The Letter by the Federal Service for Surveillance over Consumer Rights Protection and Human Well-being dated October 01, 2006 No. 0100/10460-06-32. Available at: http://50.rospotrebnadzor.ru/293/-/asset_publisher/U8Fg/content/письмо-от-02-10-2006-№-0100-10460-06-32 (date of visit August 01, 2019).
} 
protection [26]. A monograph issued and edited by G.G. Onishchenko contained certain postulates on how to combine ecological monitoring and social and hygienic monitoring systems [27].

However, normative and methodological foundation for such integration is rather scarce at the moment. Yet, all the tasks formulated within the federal project require such integration and create preconditions for its implementation on priority territories.

Our research goal was to suggest and test approaches to substantiating points and programs for monitoring over ambient air quality on concrete examples within social and hygienic monitoring activities taking into account existing ecological monitoring networks.

Data and methods. We chose two cities out of priority ones as our research objects; they were Krasnoyarsk and Chita, cities with different population, industries, and emissions structure but quite similar in terms of climatic and geographic conditions and poor sanitary-epidemiologic situations as per ambient air quality. Both territories are located in zones where the stable high-level Siberian anticyclone is localized; this anticyclone creates down flows that prevent pollutants from dispersing. There are few precipitations on both territories that can clean the atmosphere; heating season is long; energy is provided mostly by coal and boiler-oil and coal is predominantly high-ash brown one; both territories specialize in extracting and heavy industries [28].

1.09 thousand people live in Krasnoyarsk, and its area is equal to $353.9 \mathrm{~km}^{2}$. Major industries are metallurgy, machine building, metal processing, chemical industry, construction materials production etc. Gross emission into the atmosphere amounts to approximately 145 thousand tons per year. There are more than 270 chemicals (or summarily controlled groups of substances) in the admixtures list for the city. 19 admixtures are monitored at 8 stationary monitoring stations belonging to Rosgidromet' Regional Office for Hydrometeorology and Environmental Monitoring; approximately 25 admixtures are monitored at 11 mobile stations within SHM system (admixtures lists can be dif- ferent in different years). There are 5 monitoring stations within the regional monitoring system (21 admixtures under control). Economic entities in the city perform industrial control at 31 points $^{6}$. Single and/or average daily MPCs in the city that are higher than hygienic standards are detected for the following admixtures: dusts, sulfur oxide, nitrogen dioxide, hydrofluoride, chlorides, etc. In 2018 in Krasnoyarsk there were 23 registered cases of benzpyrene concentrations in the air that were higher than 10 MPC av.d. Air pollution index was considered to be very high as per criteria fixed by Rosgidromet (complex air pollution index IZA5 $>14$ ).

Population in Chita is approximately 350 thousand and the city area is $534 \mathrm{~km}^{2}$; its major industries are energy production, machine building, construction materials production, and food industry. This city is a large railroad junction. Total emissions into the atmosphere amount to approximately 53-60 thousand tons per year. 5 stationary monitoring stations that belong to the state Rosgidromet system perform systematic monitoring over 12 admixtures and register cases in which hygienic standards are violated as per concentrations of particulate matter (dust), hydrogen sulphide, and benzpyrene (up to $10 \mathrm{MPC}$ and higher).

There is a combined database on parameters of emission sources created in Krasnoyarsk; it includes emission sources related to households that don't have central heating and emissions from motor transport. There was no similar database in Chita at the moment our approaches were being developed. We considered these two territories to be test platforms where our approaches could be tested given different volumes of available initial data.

We used data and materials created in the regions by experts who had to substantiate complex plans aimed at reducing emissions of pollutants into the ambient air; we also took data provided by regional Rospotrebnadzor offices in Krasnoyarsk region and Transbaikalia region.

We analyzed data on actual emissions from industrial enterprises in Krasnoyarsk and Chita over 2014-2018 (statistical reports named "2-TP Air" for industrial enterprises), and data

\footnotetext{
${ }^{6}$ On ecological situation and environmental protection in Krasnoyarsk region in 2018: The State report. Available at: http://mpr.krskstate.ru/dat/File/3/svodnyuidoklad.pdf (date of visit August 01, 2019).
} 
on traffic intensity on major transport highways in the cities. We examined data on average annual concentrations of each admixture at each monitoring station, maximum single concentrations and single concentrations taken at 95\%frequency irrespective of a station belonging to this or that monitoring authority.

As regards results of combined calculation for a city as a whole, we took only those of them that were performed according to standardized procedures and unified software ("Ecolog" or "Ecolog-gorod" unified programs for air pollution calculation). Our procedure involved applying vector maps of the examined territories (we used ARCGIS 9.3.1 geoinformation system); each map had specific subject layers for housing areas, roads and streets, and industrial grounds. All monitoring points were given a geocode and put on relevant maps.

We took publicly available data on meteorological parameters, including average annual wind rose, that were typical for the examined territories ${ }^{7}$.

When creating our approaches, we adhered to an opinion that results of instrumental research on ambient air quality should provide a possibility to solve basic tasks that were given to the social and hygienic monitoring system at the moment ${ }^{8}$ including:

- information support for hygienic assessment (diagnostics) of the environment;

- revealing cause and effect relations between population health and exposure to environmental factors basing on system analysis and health risk assessment;

- working out recommendations on necessary actions aimed at eliminating detected adverse effects produced by environmental factors;

- detecting risk indicators implying that obligatory requirements can be violated; such indicators are usually revealed during control procedures without any interaction with juridical persons or private entrepreneurs?

We were guided by WHO postulates on how to solve tasks related to hygienic assessment, in- cluding risk assessment; some recommendations were given on locating sampling points (monitoring stations) both in housing areas with the highest contamination and in zones with the most typical concentrations of admixtures in the air (average for a city). Revealing cause and effect relations requires additional points located in zones with the lowest concentrations as data collected at such points are necessary for correct building of models for "concentrations (dose) - response (effect)" correlations $[29,30]$. Tasks related to substantiating and assessing efficiency of air-protecting activities and social and hygienic monitoring as control measures performed without any interactions with juridical persons or private entrepreneurs require monitoring points that are fully oriented at zones exposed to specific contamination sources where such activities take place.

Multi-dimensional tasks, expensive instrumental research, and limited personnel, financial, and other resources called for integration of all the systems for monitoring over air quality, including ecological monitoring, social and hygienic monitoring, and industrial control, population life and health remaining the top priority in the process. Dispersion calculations were treated as a component in the overall system for priority selection.

We assumed that a system for selecting monitoring points and programs should be dynamic; it should be revised and developed basing on both calculated data and research results obtained during a certain period.

Basic results. In case there are no results of consolidated calculations for a specific territory we suggest the following algorithm for substantiating selected points where monitoring stations and programs for monitoring over ambient air quality should be located.

1. The first task is to create a vector map of a city with industrial grounds, housing areas and all the existing points for monitoring over ambient air quality being put on it. Attribute database on industrial grounds should contain data on actual and permissible emissions of

\footnotetext{
${ }^{7}$ Open geodata catalogue. Available at: http://opengeodata.ru (date of visit August 10, 2019).

${ }^{8}$ On Approval of the Provisions on social and hygienic monitoring: The RF Government Order dated February 2, 2006 No. 60, Moscow. Available at: https://rg.ru/2006/02/17/monitoring-dok.html (date of visit August 10, 2019).

${ }^{9}$ On protecting rights of juridical persons and private entrepreneurs when state control (surveillance) and municipal control is performed: the Federal Law issued on December 26, 2008 No. 294-FL (last edited on August 02, 2019). - Clause 8.3. Available at: www.consultant.ru/document/cons_doc_LAW_83079 (date of visit August 05, 2019).
} 
contaminants into the atmosphere. A layer with data on housing should have information on population density in various parts of a city.

2. All housing areas are to be covered with a regular grid. A pitch in this grid is to be determined by the overall area of an examined territory and computational capabilities of developers. When testing our approaches, we took grids with pitches equal to $200 \times 200 \mathrm{~m}$ and $400 \times 400$ $\mathrm{m}$. A thicker grid provides the most validated conclusions; however, a grid with its pitch being equal to $400 \times 400 \mathrm{~m}$ also yielded satisfactory results that suited our analysis. A larger regular grid seems unadvisable as ground concentrations detected in zones influenced by low and average-high emissions sources tend to change considerably as a distance from a source grows and a large grid may fail to "capture" high concentrations of an admixture.

3. According to section 4.7. in Guide No. 2.1.10.1920-04 "Guide on assessing health risks under exposure to chemicals that pollute the environment" indexes showing comparative carcinogenic and non-carcinogenic hazards are to be calculated for each economic entity that is a source of pollutants-containing emissions; such calculations should be made for each substance.

3.1. Total index of carcinogenic $\left(K_{i}^{\mathrm{K}}\right)$ and non-carcinogenic $\left(\left(K_{i}^{\mathrm{H}}\right)\right.$ hazard is calculated for an enterprise (an economic entity) as per the following formula (1)

$$
K_{i}=\sum_{n=1}^{N} E_{j} \cdot T W_{j},
$$

where

$E_{j}$ is a conditional exposure to a $j$-th admixture, tons per year

$\mathrm{TW}_{\mathrm{j}}$ is a weight coefficient for influence on health that is included into calculating carcinogenic or non-carcinogenic hazard quotients according to Tables 4.7. and 4.8. P 2.1.10.1920-04 $4^{10,11}$.

$\mathrm{T}$ is a number of admixtures emitted by an economic entity.

3.2. Each enterprise is characterized with a quotient; this is a standardized "hazard" quotient $\left(K_{i}\right)$ that takes into account both carcinogenic and non-carcinogenic hazard quotients.

$$
K_{i}^{\mathrm{H}}=\frac{K_{i}}{K^{\max }}, K_{i}^{\mathrm{K}}=\frac{K_{i}}{K^{\max }}, K_{i}=K_{i}^{\mathrm{H}}+K_{i}^{\mathrm{K}},
$$

where $i$ is a number of an enterprise.

4. The geometric center of each industrial ground is linked to the central point of each square in an estimated grid with a straight line (vector $L$ ) (vectors are not designed when a point is located more than $20 \mathrm{~km}$ away from an economic entity).

5. Direction of each vector correlates with vectors in a wind rose. Each vector has its own quotient that characterizes repeatability of a wind in neighboring points of a wind rose. Vector direction is calculated as per the following formula (3):

$$
V=\frac{\left(g-g_{1}\right)}{\left(g_{2}-g_{1}\right)}\left(v_{2}-v_{1}\right)-v_{1},
$$

where $g$ is wind direction, grades;

$\mathrm{g}_{1}, \mathrm{~g}_{2}$ are vector directions in neighboring points, grades;

$v_{1}, \quad v_{2}$ is repeatability of a wind in neighboring points.

The quotient is $-L_{i m}=\frac{1}{R_{i m}} V_{i m}$,

where $m$ is a number of a square in an estimated grid.

6. Each square in an estimated gird is characterized with total hazard quotient $\left(S_{j}\right)$ that takes into account potential impacts exerted by economic entities located on a given territory:

$$
S_{m}=\sum_{i} K_{i} \cdot L_{i m} .
$$

7. It is necessary to assess whether locations of already existing monitoring stations are relevant to those of hazardous zones that can be found on a given territory and to chemical factors that create hazards in the said zones; existing monitoring programs should also be relevant to hazardous factors.

8 . The next stage is working out recommendations on how to optimize a system of monitoring over ambient air quality; this system should be based on results of the analysis and take into account the following aspects:

\footnotetext{
${ }^{10}$ See section 4.7. Guide No. 2.1.10.1920-04 Guide on assessing health risks under exposure to chemicals that pollute the environment. The RF Public Healthcare Ministry, The Federal Center for State Sanitary and Epidemiologic Surveillance. Moscow, 2004, 143 p.

${ }^{11}$ We neglected population number taking into account that any enterprise could influence a city as a whole; weakening of any influence was taken into account via a vector showing remoteness of an object from a calculated cell in a grid.
} 
- a monitoring points network should allow assessing risks for not less than $95 \%$ of population living on a given territory;

- this network should have optimal density and be distributed over a given territory allowing for instrumental research becoming less and less representative the greater is a distance form a monitoring point ${ }^{12}$;

- a monitoring program should include all the admixtures that can potentially create unacceptable health risks or make a considerable contribution into them (from 10 to $100 \%$ );

- this program may include substances that are marker ones (indicators) for enterprises with maximum emissions and greatest hazards as per calculated criterion $\mathrm{K}_{\mathrm{i}}$.

The approach was tested on the example of Chita; the test results were as follows:

- potential hazards for the city population that occur due to emissions from industrial enterprises are not homogenous (Figure 1);

- monitoring stations that belong to Rosgidromet monitoring system can be considered an integral part of the total monitoring network without any changes in their location;

- there should be at least two additional monitroing points (in north-western and eastern parts of housing area, in squares numbered 925 and 434), and it is well-grounded taking into account health risks and consequent assessment whether activities performed within "Clean air" project are efficient or not.

- emissions that contain sulfur dioxide, dusts, nitrogen oxides, manganese compounds, carbon oxide, benzpyrene, soot, fluorides, and hydrocarbons are priority ones in terms of health risks caused by them (Table 1).

Practically all the priority admixtures, except from manganese, are covered by already existing monitoring programs. Manganese is recommended to be included as an additional component. Besides, it is recommended to measure not only a sum of dusts at all the monitoring stations but also fine-dispersed fractions PM10 and PM2.5 as they are the most hazardous for human health $[31,32]$.

In case there are some consolidated calculations of emissions dispersion for a city as a whole we can suggest the following algorithm for substantiating selected points where monitoring stations are to be located and programs for monitoring over ambient air quality.

1. The first step is to create a database where each estimated point on a given territory is characterized with aggregate concentrations of $\mathrm{N}$ ingredients. This database is a matrix built on a database containing output files with calculation results.

2. The next step is calculating carcinogenic and acute and chronic non-carcinogenic risks

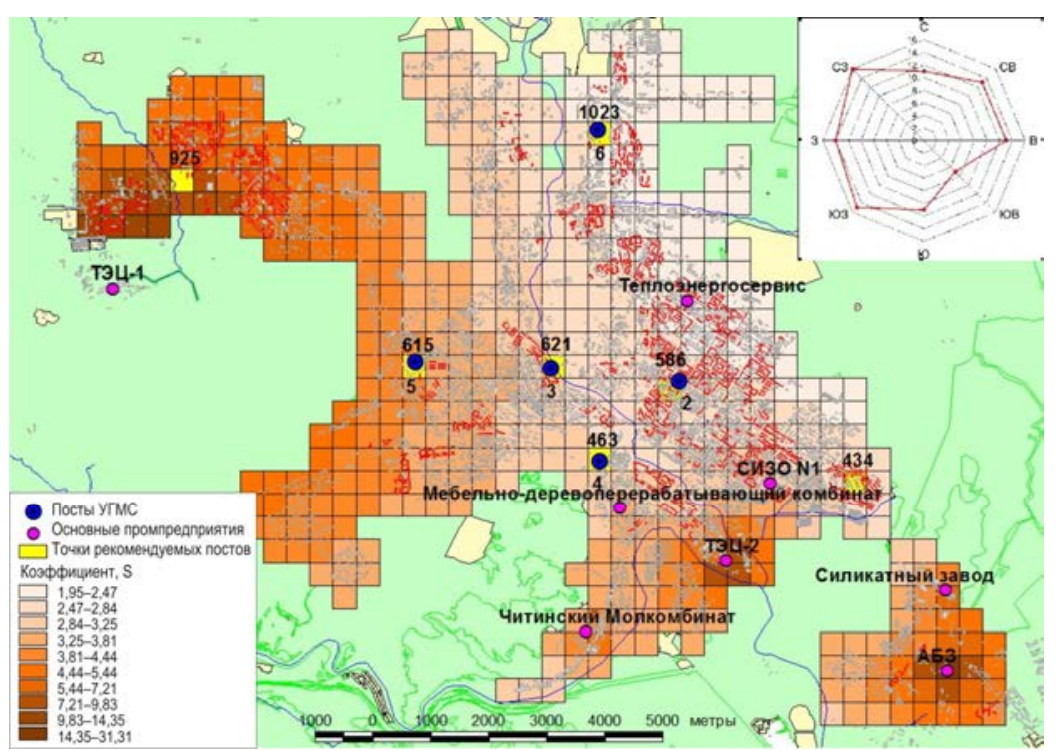

Figure 1. A map showing spatial distribution of comparative hazard index in Chita; hazards for population health are created by emissions from satitonary sources

\footnotetext{
${ }^{12}$ See section 3.4.2 Guide 52.04.186-89. Guide on control over air pollution. Moscow, 1991, 693 p.
} 
A fragment of a table that ranks admixtures as per their total hazards caused by all the chemical admixtures contained in emissions from industrial enetrprises

located in Chita (as per data collected in 2018)

\begin{tabular}{|l|c|c|}
\hline \multicolumn{1}{|c|}{ Chemical } & \multicolumn{2}{c|}{ Total hazard quotient of an admixture } \\
\cline { 2 - 3 } & Non-carcinogenic & Carcinogenic \\
\hline Sulfur dioxide (Sulfury anhydride) & $1,274,408.2$ & \\
\hline Boiled oil ash (recalculated as per vanadium) & $824,033.1$ & \\
\hline Dust (as a sum of dusts with various chemical structure) & $756,791.7$ & \\
\hline Carbon (soot) & $461,279.6$ & $461,307.1$ \\
\hline Nitrogen dioxide & $457,863.2$ & \\
\hline Nitrogen (II) oxide & $75,592.5$ & \\
\hline Manganese and its compounds & $3,902.57$ & \\
\hline Carbon oxide & $2,397.23$ & \\
\hline Dimethylbenzene (Xylene) (a mixture of o-, m-, and p-isomers) & $1,026.51$ & \\
\hline Benzpyrene (3,4-Benzpyrene) & 220.00 & 22.0 \\
\hline White-spirit & 40.58 & \\
\hline Poorly soluble fluorides & 31.01 & \\
\hline Gaseous fluorides & 18.68 & \\
\hline Saturated hydrocarbons C12-C19 & 18.49 & \\
\hline Sulfuric acid (as per H2SO4 molecule) & 14.98 & \\
\hline Dihydrosulfide (Hydrogen sulfide) & 3.73 & \\
\hline Formaldehyde & 2.72 & 0.272 \\
\hline
\end{tabular}

basing on all the obtained data; calculations are to be made for each estimated point in a grid according to conventional procedures ${ }^{13}$ :

- hazard quotients for acute non-carcinogenic effects (HQac) calculated for priority chemicals that have scientifically grounded potential ability to exert acute negative influence on a human body; maximum single concentrations of examined chemicals are to be applied in this calculation;

- hazard quotients for chronic non-carcinogenic effects (HQcr) calculated for priority chemicals that have scientifically grounded potential ability to exert chronic negative influence on a human body; average annual concentrations of examined chemicals are to be applied in this calculation;

- individual carcinogenic risk (CR) for priority chemicals that have carcinogenic effects;

4. In order to divide a city territory into specific zones as per health risks, it is necessary to perform cluster analysis as per conventional procedures that allow dividing an examined selection of estimated points into clusters with "similar" parameters.
As parameters of carcinogenic and noncarcinogenic risks have different dimensions, it is necessary to standardize objects (parameters) prior to clusterization (5):

$$
Y=\frac{X-\bar{X}}{S}
$$

where

$X$ is an initial vales of a parameter;

$Y$ is a standardized value of a parameter;

$\bar{X}$ is an average value of a parameter;

$S$ is a standard deviation.

5 . When selecting a point where a station for monitoring over ambient air quality is to be located, the following requirements should be taken into account:

- a station in a selected zone (cluster) should be located at a point with the highest or typical parameters of a risk that occurs in a given zone,

- a station should be located in a zone with the highest density of exposed population.

In order to spot out a relevant point where a station for monitoring over ambient air quality is to be located within SHM system, a layer of clusters intersects with a layer that shows population

${ }^{13}$ Guide. 2.1.10.1920-04 Guide on assessing health risks under exposure to chemicals that pollute the environment. The RF Public Healthcare Ministry, The Federal Center for State Sanitary and Epidemiologic Surveillance. Moscow, 2004, 143 p. 
density, the latter being a grid covering the overall housing area. As a result, each cell in a grid contains data on a number of population living on a given territory and parameters of occurring carcinogenic and non-carcinogenic risks. Due to layers intersection one can choose reference points within cluster boundaries where population density is higher than $75 \%$ of the maximum population density in a given cluster $\left(>75 \% \mathrm{P}^{\mathrm{N}}\right.$ max $)$.

6. A list of contaminants that are to be measured at a selected point is determined via ranking health risk factors as well as with ranking tables taking into account material and normative resources available for a test laboratory.

We tested our approach on the example of Krasnoyarsk together with preliminary assessment of hazards caused by emissions as per the first algorithm.

The results were satisfactory similar as regards substantiating zones (points) where monitoring stations should be located. Monitoring stations network is sufficiently thick and it is advisable to only slightly relocate mobile stations used within a system of social and hygienic monitoring (Figure 2).

Priorities fixed as per potential hazards caused by admixtures (Table 2), results of dispersion calculation, and field observations results didn't coincide completely.

Thus, as per data on calculated dispersion in housing areas in the city (where monitoring sta- tions are located) ground concentrations that were higher than MPC were detected for nitrogen dioxide (1.4 $\mathrm{MPS}_{\mathrm{M} . \mathrm{s} .}$ and $3.9 \mathrm{MPC}_{\text {av.d.), acrolein (up to }}$ 1.1 $\mathrm{MPS}_{\mathrm{M} . \mathrm{S}}$ ), non-organic dusts (up to $2.2 \mathrm{MPS}_{\mathrm{M} . \mathrm{s}}$ at $0.06 \mathrm{MPC}_{\mathrm{av} . \mathrm{d}}$ ), hydrocarbons (up to $3 \mathrm{MPC}$ ). These data are partially confirmed by field observation results as nitrogen dioxide in concentrations higher than MPC is registered at many stations within Rosgidromet monitoring system and SHM system located in the region (1.1-1.9 $\mathrm{MPS}_{\mathrm{M} . \mathrm{s}}$; 1.1-1.8 $\mathrm{MPC}_{\mathrm{av.d} .}$.). There were also excessive concentrations of particulate matter (up to $\left.5 \mathrm{MPS}_{\mathrm{M} . \mathrm{S}}\right)$. Acrolein and hydrocarbons were not measured at monitoring stations and it is rather complicated to verify all the calculation results.

We detected substantial discrepancies between calculated and instrumental data as regards aromatic hydrocarbons: calculations performed on the basis of combined databases didn't reveal any "alarming" levels practically for any substance from this group (that is, there were no detected concentrations close to MPC or higher than it). But at the same time, there were excessive concentrations of certain chemicals measured at monitoring stations within Rosgidromet system; thus, benzene was detected in concentrations up to 5.2 MPC; xylene, up to 3.2 MPC; toluene, up to 1.5 MPC; ethylbenzene, up to $5 \mathrm{MPC}$. We also detected that hygienic standards were violated for such substances as fluorides (excessive concentrations detected at

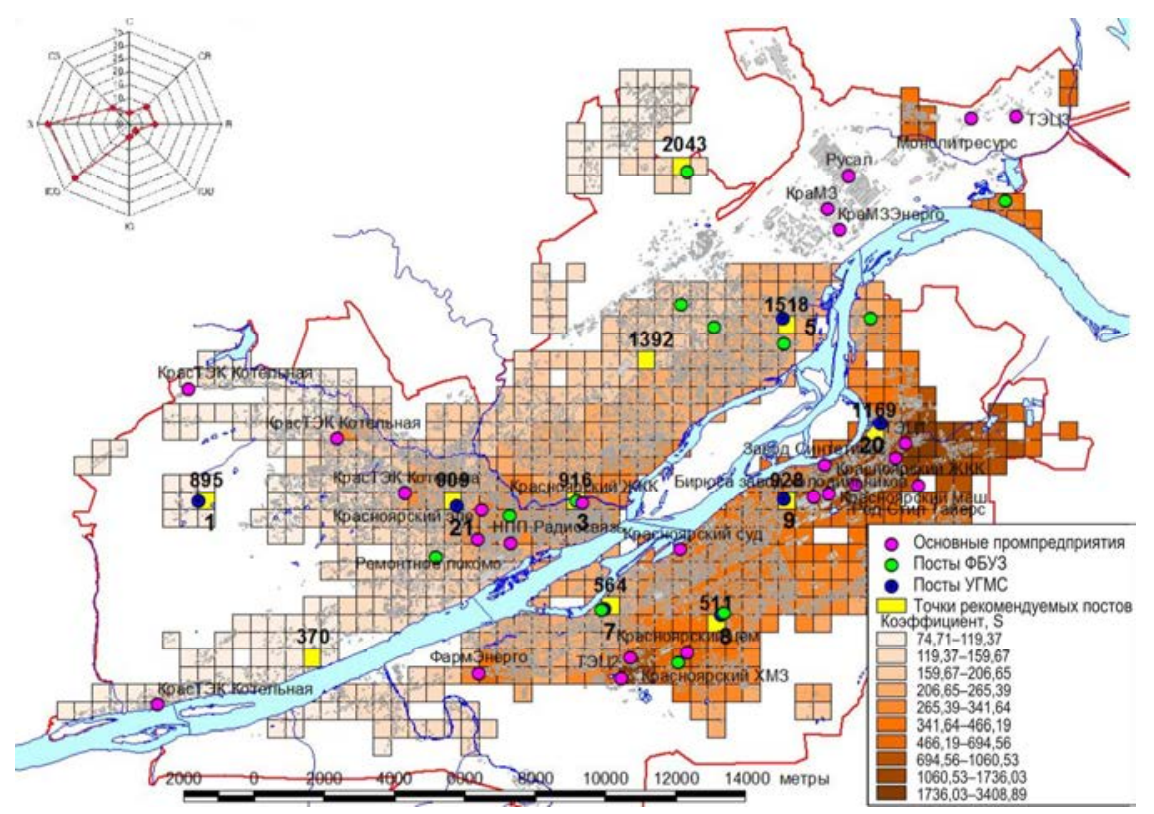

Figure 2. A map showing spatial distribution of comparative hazard index in Krasnoyarsk; hazards for population health are caused by emissions from stationary sources 
A fragment of a table that ranks admixtures as per their total hazards caused by all the chemical admixtures contained in emissions from industrial enetrprises located in Krasnoyarsk (as per data collected in 2018)

\begin{tabular}{|l|c|c|}
\hline \multirow{2}{*}{ Chemical } & \multicolumn{2}{c|}{ Total hazard quotient of an admixture } \\
\cline { 2 - 3 } & Non-carcinogenic & Carcinogenic \\
\hline Sulfur dioxide (Sulfury anhydride) & $2,632,501.3$ & \\
\hline Nitrogen dioxide (Nitrogen (IV) oxide) & $1,893,227.7$ & \\
\hline Dusts & $1,854,052.3$ & \\
\hline Gaseous fluorides & $495,105.4$ & \\
\hline Poorly soluble fluorides & $410,583.1$ & \\
\hline Nitrogen (II) oxide (Nitrogen oxide) & $235,589.1$ & \\
\hline Carbon (soot) & $116,760.8$ & $116,764.0$ \\
\hline Benzpyrene (3,4-Benzpyrene) & $113,814.7$ & $11,381.5$ \\
\hline Buta-1,3-dien (1,3-Butadien, divinyl) & $95,961.1$ & 95,961 \\
\hline Aluminum trioxide (recalculated as per aluminum) & $68,480.8$ & \\
\hline Chlorine & $65,277.9$ & \\
\hline Carbon oxide & $54,542.9$ & \\
\hline Epichlorohydrine & $33,726.6$ & \\
\hline Manganese and its compounds & $28,133.4$ & \\
\hline Prop-2-ennitrile (Acrylonitrile) & $14,450.6$ & $14,450.6$ \\
\hline Chromium (Hexavalent chromium) & $14,251.4$ & $14,251.4$ \\
\hline Copper oxide (recalculated as per copper) & $10,025.1$ & \\
\hline Hydrochloride acid & $5,102.7$ & \\
\hline Sulfuric acid (as per H2SO4 molecule) & $4,404.6$ & \\
\hline Xylene (mixture of o-, m-, p-isomers) & $3,726.8$ & \\
\hline Ammonia & $2,773.2$ & \\
\hline Vanadium (V) oxide & $1,713.6$ & \\
\hline Ethenylbenzene (Vinilbenzene, Styrene) & $1,325.4$ & \\
\hline Hydrogen cyanide & $1,225.2$ & \\
\hline Prop-2-en-1-al (Acrolein) & 254.0 & \\
\hline Trichloroethylene & 244.3 & \\
\hline 1,2,4-Trimethylbenzene (Pseudocumene) & 177.1 & \\
\hline Methylbenzene (Toluene) & 138.8 & \\
\hline Saturated hydrocarbons C12-C19 & 127.3 & \\
\hline 2-Chlorobutadien-1,3-dien (Chloroprene) & 123.2 & \\
\hline Ethene (Ethylene) & 100.0 & \\
\hline Lead and its non-organic compounds & 70.7 & \\
\hline Hydroxibenzene (Phenol) & 64.2 & \\
\hline Butyl acetate & 62.3 & \\
\hline Tetrachloroethylene (Perchloroethylene) & 57.6 & \\
\hline Formaldehyde & 42.0 & \\
\hline Benzene & 1.70 & \\
\hline & & \\
\hline
\end{tabular}

6 monitoring stations within Rosgidromet system out of 8); such concentrations were not predicted by dispersion calculations. That is, hazardous concentrations of fluorides can occur on a considerable part of the city area and exert negative influence on population health.

Calculated ground concentrations of such admixtures as metals (aluminum, copper, manga- nese, nickel, and cobalt) were equal to hundredths and thousandths of MPC and it allowed us to neglect them when creating monitoring programs, even taking into account health risks. In retrospect there were no monitoring, screening, or reconnaissance instrumental measurements of such admixtures performed on a territory. It was impossible to verify results of dispersion calculation. 
Given that, we were guided by the following system of criteria when making recommendations on including an admixture (a substance) into a monitoring program:

- as per data collected via previous instrumental research, concentrations of an admixture that were higher than hygienic standards were registered directly at this monitoring point or at the closes monitoring station;

- as per results of combined dispersion calculations ground concentrations of a substance are predicted to be higher than MPC, but there have been no instrumental measurements of ground concentrations as regards this substance (admixture);

- as per data obtained via preliminary calculations of hazard quotients an admixture is among priority ones for a territory, but there have been no instrumental measurements of ground concentrations as regards this admixture;

- an admixture is an indicator (a marker one) for emissions from the largest enterprise on a territory, but there have been no instrumental measurements of ground concentrations as regards this substance (admixture);

- an admixture is detected in concentrations that allow predicting a substantial contribution into total carcinogenic or non-carcinogenic risk for population health as per data obtained via dispersion calculation or filed data.

Model recommendations on monitoring programs within SHM are given in Table 3.

We took into account a possibility that a program could be adjusted in future as per results of systematic examinations; for example, experts can exclude admixtures registered in concentrations that don't create unacceptable health risks, as well as admixtures that don't substantially increase health risks when they are combined with other substances with one-direction effects.

Conclusion. Our research proved that it was vital and well-timed to combined efforts taken by authorities and organizations that are responsible for assessing and managing ambient air quality on various territories. Should a combined monitoring network that includes both stationary and mobile stations of Rosgidromet, Rospotrebnadzor, and regional monitoring stations, be created, it would allow saving as many resources as possible and simultaneously create optimally thick and representative infrastructure for collecting data on actual ambient air quality. Measurement programs within existing Rosgidromet monitoring system that solves its own tasks could include admixtures that are priority ones as per health risks criteria. These measurements could be supplemented with examinations performed on the basis of monitoring networks within social and hygienic monitoring. Combined programs for sampling procedures and measurement techniques would allow taking into account all the data arrays both for Rosgidromet's and Rospotrebnadzor's authorities and organizations.

Data obtained via combined dispersion calculation at the moment should be treated as an additional information source that provides a better insight into specific spatial distribution of contamination. And here it seems to be ungrounded to rely only on calculation results due to substantial discrepancies between calculated data and field ones. But still, these detected discrepancies can give grounds for greater attention paid by surveillance authorities to certain economic entities and standards of permissible emissions fixed for them; they can also substantiate certain measures taken by control and surveillance authorities to identify contamination sources that are not included into combined databases and that are not taken into account when permissible exposure levels are fixed.

We have tested and suggested applying methodical approaches to substantiating points and programs for monitoring over ambient air quality within social and hygienic monitoring taking into account the existing ecological monitoring networks. At present these approaches can be implemented on any territory, both included into priority lists within the Federal project "Clean air" and those which are not in these lists. There is only one condition for their implementation to be efficient and it is decision-makers taking a genuine interest in receiving as complete and valid data on ambient air quality as it is only possible. These decision-makers should really be keen on providing safety and sanitary-epidemiologic welfare of the population.

Gratitude. The authors are deeply grateful to S.E. Lape, the Chief Sanitary Inspector of Transbaikalia Rospotrebnadzor Regional Office and D.V. Goryaev, the Chief Sanitary Inspector in Krasnoyarsk region, 
Methodical approaches to selecting observation points and programs for observation over ambient air quality...

Table 3

Recommendations on a program for monitoring over ambient air quality within social and hygienic monitoring activities for Krasnoyarsk (a fragment)

\begin{tabular}{|c|c|}
\hline & ed into a program \\
\hline \multicolumn{2}{|c|}{$\begin{array}{l}\text { A mobile monitoring station belonging to Krasnoyarsk Regional Center for Hygiene } \\
\text { and Epidemiology, Parkovaya str., 19. (coordinates: } \text { n.l. } 56.02002 \text { e.l. 092.97704) }\end{array}$} \\
\hline Chemical & Criteria for an admixture to be included into a program \\
\hline Nitrogen (II) oxide & $\begin{array}{l}\text { Concentrations deviate from hygienic standards } \\
\text { Creates unacceptable acute and chronic health risks }\end{array}$ \\
\hline Nitrogen dioxide & $\begin{array}{l}\text { Concentrations deviate from hygienic standards } \\
\text { Creates unacceptable acute and chronic health risks }\end{array}$ \\
\hline Sulfur dioxide & $\begin{array}{l}\text { Considerable contribution into chronic health risk (respiratory organs diseases, addi- } \\
\text { tional population mortality) }\end{array}$ \\
\hline Carbon oxide & $\begin{array}{l}\text { Considerable contribution into chronic health risk (cardiovascular system diseases, } \\
\text { blood diseases) }\end{array}$ \\
\hline $\begin{array}{l}\begin{array}{l}\text { Particulate matter } \\
\text { (sum of dusts) }\end{array} \\
\end{array}$ & $\begin{array}{l}\text { Considerable contribution into chronic health risk (respiratory organs diseases, car- } \\
\text { diovascular system diseases, additional population mortality) }\end{array}$ \\
\hline Particulate matter PM10 & $\begin{array}{l}\text { Considerable contribution into chronic health risk (respiratory organs diseases, car- } \\
\text { diovascular system diseases, additional population mortality) }\end{array}$ \\
\hline Particulate matter PM2,5 & $\begin{array}{l}\text { Considerable contribution into chronic health risk (respiratory organs diseases, car- } \\
\text { diovascular system diseases, additional population mortality) }\end{array}$ \\
\hline Ammonia & Considerable contribution into chronic health risk (respiratory organs diseases) \\
\hline Fluorides & $\begin{array}{l}\text { Considerable contribution into chronic health risk (respiratory organs diseases, } \\
\text { musculoskeletal system diseases). }\end{array}$ \\
\hline Formaldehyde & Considerable contribution into carcinogenic health risk \\
\hline Benzpyrene & $\begin{array}{l}\text { Concentrations deviate from hygienic standards. Considerable contribution into car- } \\
\text { cinogenic health risk }\end{array}$ \\
\hline Dihydrosulphide & Examined within reconnaissance, makes a living environment uncomfortable \\
\hline Acetaldehyde & Examined within reconnaissance. Carcinogen \\
\hline Prop-2-en-1-al (Acrolein) & Potentially considerable contribution into health risk (respiratory organs diseases) \\
\hline \multicolumn{2}{|c|}{$\begin{array}{l}\text { A mobile monitoring station belonging to Krasnoyarsk Regional Center for Hygiene } \\
\text { and Epidemiology, Partizana Zheleznyaka str., } 36 \text { A (coordinates n.l. 56.03596 e.l. 92.92622) }\end{array}$} \\
\hline Nitrogen dioxide & $\begin{array}{l}\text { Concentrations deviate from hygienic standards. Creates unacceptable acute and } \\
\text { chronic health risks }\end{array}$ \\
\hline Sulfur dioxide & $\begin{array}{l}\text { Considerable contribution into chronic health risk (respiratory organs diseases, addi- } \\
\text { tional population mortality) }\end{array}$ \\
\hline Carbon oxide & $\begin{array}{l}\text { Considerable contribution into chronic health risk (cardiovascular system diseases, } \\
\text { blood diseases) }\end{array}$ \\
\hline $\begin{array}{l}\text { Particulate matter (a sum } \\
\text { of dusts) }\end{array}$ & $\begin{array}{l}\text { Considerable contribution into chronic health risk (respiratory organs disease, car- } \\
\text { diovascular system diseases, additional population mortality) }\end{array}$ \\
\hline Particulate matter PM10 & $\begin{array}{l}\text { Considerable contribution into chronic health risk (respiratory organs diseases, car- } \\
\text { diovascular system diseases, additional population mortality) }\end{array}$ \\
\hline Particulate matter PM2,5 & $\begin{array}{l}\text { Considerable contribution into chronic health risk (respiratory organs diseases, car- } \\
\text { diovascular system diseases, additional population mortality) }\end{array}$ \\
\hline Benzpyrene & Concentrations are higher than MPC. Considerable contribution into carcinogenic health risk \\
\hline Aluminum & $\begin{array}{l}\text { A marker of emissions from a large air contamination sources. Potentially } \\
\text { considerable contribution into chronic health risk (respiratory organs disease, } \\
\text { central nervous system diseases, musculoskeletal system diseases) }\end{array}$ \\
\hline Fluorides & $\begin{array}{l}\text { Considerable contribution into chronic health risk (respiratory organs disease, mus- } \\
\text { culoskeletal system diseases) }\end{array}$ \\
\hline Nickel and its compounds & $\begin{array}{l}\text { A marker of emissions from a large air contamination sources. Potentially consider- } \\
\text { able contribution into carcinogenic health risk }\end{array}$ \\
\hline Cobalt & $\begin{array}{l}\text { A marker of emissions from a large air contamination sources. Potentially consider- } \\
\text { able contribution into carcinogenic health risk }\end{array}$ \\
\hline Acetaldehyde & Examined within reconnaissance. Carcinogen \\
\hline
\end{tabular}


for providing timely and complete access to initial data that were necessary for our analysis. The authors are also grateful to $\mathrm{S} . \mathrm{Yu}$. Balashov, S.Yu. Zagorodnov, E.V. Popova, D.M. Kiryanov, and V.M. Chigvintsev (all are members of the Federal Scientific Center for Medical and Preventive Health Risk Manage- ment Technologies stuff) for the assistance they rendered in accomplishing this paper.

Funding. The research was not granted any sponsor support.

Conflict of interests. The authors state there is no any conflict of interests.

\section{References}

1. Popova A.Yu. Strategic priorities of the Russian Federation in the field of ecology from the position of preservation of health of the nation. Zdorov'e naseleniya i sreda obitaniya, 2014, no. 2 (251), pp. 4-7 (in Russian).

2. Azarov V.N., Sidyakin P.A., Lopatina T.N., Nikolenko D.A. Technogenic pollution of the atmosphere air and its influence on social and ecological wellbeing of the resort towns of the caucasian spas. Sotsiologiya goroda, 2014, no. 1, pp. 28-37 (in Russian).

3. Badmaeva S.E., Tsimmerman V.I. Anthropogenic pollution of the atmosphericair in the Krasnoyarsk territory cities. Vestnik Krasnoyarskogo gosudarstvennogo agrarnogo universiteta, 2015, no. 2 (101), pp. 27-32 (in Russian).

4. Daulbaeva A.N. the analysis of pollution of atmospheric air in Khazakhstan. Novaya nauka: Problemy i perspektivy, 2016, vol. 10, no. 2, pp. 20-23 (in Russian).

5. Scoggins, A., Kjellstrom, T., Fisher, G., Connor, J., Gimson, N. Spatial analysis of annual air pollution exposure and mortality. Science of the Total Environment, 2004, vol. 321, no. 1-3, pp. 71-85. DOI: $10.1016 /$ j.scitotenv.2003.09.020

6. Chernyaeva V.A., Wang D.H. Regional Environmental Features and Health Indicators Dynamics. Pollution of the Earth's Atmosphere and International Air Quality Standards. IOP Conference Series: Earth and Environmental Science, 2019, 6 p.

7. Fablov S.A. Proizvodstvennyi ekologicheskii kontrol' v oblasti okhrany atmosfernogo vozdukha [Industrial ecological control in ambient air protection]. Alleya nauki, 2018, vol. 5, no. 10 (26), pp. 13-18 (in Russian).

8. Kostyuchenko M.N., Volokhova L.T., Stepanyuk V.D., Volokhova M.N. Productive Ecological Control on Bakery Enterprises in Area of Guard of Atmospheric Air. Khlebopechenie Rossii, 2018, no. 4, pp. 12-16 (in Russian).

9. Ovchinnikova E.L., Fridman K.B., Novikova Yu.A. Problems of social and hygienic monitoring in new legal conditions. Zdorov'e - osnova chelovecheskogo potentsiala: problem i puti ikh resheniya, 2018, vol. 13, no. 2, pp. 939-949 (in Russian).

10. Iskhakova M.K., Danilova K.A., Popov A.V., Mal'kova I.L. The analysis of relation between the pollution of atmospheric air and health of children's population in system of social and hygienic monitoring. Sotsial'nye, gumanitarnye, mediko-biologicheskienauki, 2014, vol. 16, no. 5-2, pp. 874-877 (in Russian).

11. Rzaev R.P. Sotsial'no-gigienicheskii monitoring kachestva atmosfernogo vozdukha dlya otsenki vozdeistviya na zdorov'e cheloveka [Social-hygienic monitoring over ambient air quality aimed at assessing exposure on human health]. Bezopasnost' i okhrana truda, 2011, no. 2 (47), pp. 61-62 (in Russian).

12. Prosviryakova I.A. Methodological approaches to the organization of analytical (laboratory) monitoring of pollutants in ambient air at the border of sanitary-protective and residential area. Zdorov'e $i$ okruzhayushchaya sreda, 2014, vol. 1, no. 24, pp. 18-20 (in Russian).

13. Kirsanov V.V., Smolko A.A. Monitoring prirodookhrannoi deyatel'nosti predpriyatii neftekhimicheskogo kompleksa [Monitoring over environmental activities accomplished at petrochemical enterprises]. Ekologiya i promyshlennost' Rossii, 2007, no. 12, pp. 10-13 (in Russian).

14. Astapenko E.O. O nekotorykh aspektakh primeneniya skhemy sistemnogo ekologicheskogo monitoringa v zone vliyaniya neftekhimicheskikh predpriyatii Khanty-mansiiskogo Avtonomnogo okruga Yugry [On certain aspects related to application of systemic environmental monitoring in zones influenced by petrochemical enterprises located in Khanty-Mansi Autonomous Area]. Innovatsii i investitsii, 2015, no. 7, pp. 8-12 (in Russian).

15. Vinokurova M.V., Vinokurov M.V., Gurvich V.B., Kuzmin S.V., Malykh O.L. Assessment of ambient air quality in the localities by the calculation method in the sociohygienic monitoring. Gigiena $i$ sanitariya, 2004, no. 5, pp. 25-26 (in Russian).

16. Kiselev A.V., Grigor'eva Ya.V. Primenenie rezul'tatov rascheta zagryazneniya atmosfernogo vozdukha dlya sotsial'no-gigienicheskogo monitoringa [Application of results obtained via calculating ambient air contamination within social-hygienic monitoring activities]. Gigiena i sanitariya, 2017, vol. 96, no. 4, pp. 306-309 (in Russian). 
17. Volkodaeva M.V. Ispol'zovanie geoinformatsionnykh tekhnologii dlya zadach optimizatsii razmeshcheniya stantsii monitoring kachestva atmosfernogo vozdukha [Geoinformation technologies applied to choose the most optimal locations for stations where ambient air quality is monitored]. Zapiski Gornogo instituta, 2015, vol. 215, pp. 107-114 (in Russian).

18. Zaitseva N.V., May I.V., Kleyn S.V. Optimizatsiya program nablyudeniya za kachestvom atmosfernogo vozdukha selitebnykh territorii $\mathrm{v}$ sisteme sotsial'no-gigienicheskogo monitoring na baze prostranstvennogo analiza i otsenki riska dlya zdorov'ya naseleniya [Optimizations of programs aimed at ambient air quality monitoring in settlements within social-hygienic monitoring activities based on spatial analysis and health risk assessment]. Permskii meditsinskii zhurnal, 2010, vol. 27, no. 2, pp. 130-138 (in Russian).

19. Igonin E.I., Shlychkov A.P., Shagidullin A.R., Shagidullin R.R. Optimization of the regional atmospheric air monitoring system on the example of Nizhnekamsk. Rossiiskii zhurnal prikladnoi ekologii, 2016, no. 3 (7), pp. 33-39 (in Russian).

20. Kiku P.V., Anan'ev V.U., Sigaev D.S., Sitter N.S., Bogdanova V.D., Zavyalova Y.S. Assessment of health risks of the population of Vladivostok when exposed to atmospheric air. Zametki uchenogo, 2015, no. 3, pp. 157-160 (in Russian).

21. Soares, P.H., Monteiro, J.P., Freitas, H.F., Zenko Sakiyama R., Andrade, C.M. Platformformonitoringandanalysisofairquality in environments with large circulation of people. Environmental Progress and Sustainable Energy, vol. 37, no. 6, 2018, pp. 2050-2057.

22. Gayer A., Adamkiewicz Ł., Mucha D., Badyda A. Air quality health indices -Review. Fire and Environmental Safety Engineering, Lviv; Ukraine, 2018. Available at: https://www.matec-conferences.org/articles/matecconf/abs/2018/106/matecconf_fese2018_00002/matecconf_fese2018_00002.html (26.09.2019).

23. Roslyakov P.V., Morozov I.V., Ionkin I.L., Kondrat'eva O.E., Seregin V.A., Nikiforov L.V. Opyt ekspluatatsii sistemy nepreryvnogo kontrolya i regulirovaniya vrednykh vybrosov na TETs MEI [Experience in operating a continuous control system and regulation over hazardous emissions at the heating plant of Moscow Institute of High-Power Engineering]. Promyshlennaya energetika, 2015, no. 12, pp. 46-56 (in Russian).

24. Roslyakov P.V., Ionkin I.L., Kondrateva O.E., Borovkova A.M., Seregin V.A., Morozov I.V. Continuous emission monitoring and accounting automated systems at an HPP. Teploenergetika, 2015, no. 3, pp. 67-74 (in Russian).

25. Darenskikh V.A. The problems of states upervision and production control in the field of legal protection of atmospheric air. Sovremennye issledovaniya, 2018, no. 2 (06), pp. 16-17 (in Russian).

26.Ovchinnikova E.L., Fridman K.B., Novikova Yu.A. Zadachi sotsial'no-gigienicheskogo monitoringa v novykh pravovykh usloviyakh [Issues related to social and hygienic monitoring under the new legislation]. Zdorov'eosnova chelovecheskogo potentsiala: problemy i puti ikh resheniya, 2018, vol. 13, no. 2, pp. 939-949 (in Russian).

27. Analiz riska zdorov'yu v strategii gosudarstvennogo sotsial'no-ekonomicheskogo razvitiya [Health risk analysis in the state strategy for social and economic development]. In: G.G. Onishchenko, N.V. Zaitseva eds. Perm, 2014, 738 p. (in Russian).

28. Klyuev N.N., Yakovenko L.M. «Dirty» cities in Russia: factors determining air pollution. Vestnik rossiiskogo universiteta druzhby narodov. Seriya: ekologiya i bezopasnost' zhiznedeyatel'nosti, 2018, vol. 26, no. 2, pp. 237-250 (in Russian). DOI: 10.22363/2313-2310-2018-26-2-237-250

29. Air Quality Guidelines for Europe, Second Edition. WHO Regional Publication. European Series, 2000, Copenhagen, no. 91, 288 p.

30. Monitoring kachestva atmosfernogo vozdukha dlya otsenki vozdeistviya na zdorov'e cheloveka [Monitoring over ambient air quality aimed at assessing exposure on human health]. WHO Regional Publication. European Series, 2001, Copenhagen, no. 85, 2001, 316 p. (in Russian).

31. Miri M., Alahabadi A., Ehrampush M.H., Rad A., Lotfi M.H., Sheikhha M.H., Sakhvidi M.J.Z. Mortality and morbidity due to exposure to ambient particulate matter. Ecotoxicology and Environmental Safety, no. 165, pp. 307-313. DOI: 10.1016/j.ecoenv.2018.09.012

32. Kim H.-B., Shim J.-Y., Park B., LeeY.-J. Long-Term Exposure to Air Pollutants and Cancer Mortality: A Meta-Analysis of Cohort Studies.International journal of environmental research and public health, 2018, vol. 15, no. 11, pp. 2608. DOI: 10.3390/ijerph15112608

Zaitseva N.V., May I.V., Kleyn S.V., Goryaev D.V. Methodical approaches to selecting observation points and programs for observation over ambient air quality within social and hygienic monitoring and "pure air" federal project. Health Risk Analysis, 2019, no. 3, pp. 4-17. DOI: 10.21668/health.risk/2019.3.01.eng

Received: 20.07.2019

Accepted: 15.09 .2019

Published: 30.09.2019 
UDC 614.7

DOI: $10.21668 /$ health.risk/2019.3.02.eng

\title{
POPULATION HEALTH RISK CAUSED BY EXPOSURE TO CHEMICALS IN SOILS
}

\author{
A.N. Deryabin ${ }^{1,2}$, T.N. Unguryanu ${ }^{1,2}$, R.V. Buzinov ${ }^{1,2}$ \\ ${ }^{1}$ Federal Service for Surveillance over Consumer Rights Protection and Human Wellbeing, Arkhangelsk Region \\ office, 24 Gaidara Str., Arkhangelsk, 163000, Russian Federation \\ ${ }^{2}$ Northern State Medical University, 51 Troitskiy Ave., Arkhangelsk, 163000, Russian Federation
}

Our research goal was to comparatively analyze soils contamination with chemicals in cities located in the Arctic zone of Arkhangelsk region and to assess population health risk caused by soils in settlements contaminated with chemicals. The research has practical significance due to Arkhangelsk region being among the RF regions with the highest share of soils samples taken in settlements that deviate from hygienic standards as per sanitary-chemical and microbiological parameters.

The assessment was based on monitoring data on chemical contamination of soils in cities located in the Arctic zone of Arkhangelsk region (Severodvinsk, Arkhangelsk, and Novodvinsk) collected in 2007-2017. We assessed population exposure to contaminants in soils at their oral and subcutaneous introduction and determined risk levels for children's and adults' health. To examine non-carcinogenic effects, we applied reference doses and calculated hazard coefficients and indexes. We revealed that soils were contaminated with metals substantially greater in Severodvinsk than in two other cities. Aggregated hazard indexes calculated for combined introduction of contaminants from soils didn't exceed 1.0. Contaminants from soils primarily enter a body via oral introduction. A contribution made by oral introduction into a total dose for examined toxicants amounted to 68-79\% at the median level among children and adults. Overall individual carcinogenic risk in Severodvinsk was higher than in two other cities and amounted to $9.1 \cdot 10^{-4}$ and $2.3 \cdot 10^{-3}$ at the median level and 90\%-percentile one accordingly. Non-carcinogenic and carcinogenic risks caused by exposure to contaminants in soils are acceptable when taken in their median concentrations.

Key words: soil contamination, chemicals, soils in settlements, deviation from hygienic standards, risk assessment, risk level.

Soil is a most significant component in the environment; it accumulates chemicals and causes secondary contamination of ambient air and water [1, 2]. Chemicals occur in soil mostly due to discharges and emissions from industrial enterprises, motor transport, communal and industrial wastes [3-7].

Chemical contaminants in soil can exert their influence on population health both via direct contacts with soils (handworks with soils, walking barefoot, children playing in sandboxes etc.) and via chemicals penetrating a body indirectly via media that contact soils (ambient air or water) [3, 8]. Heavy metals are the most hazardous toxicants for human health [9-11] as they produce toxic, allergenic, carcinogenic, and mutagenic effects [12, 13]. Copper, zinc, nickel, lead, and cadmium are among priority chemical soil contaminants $[3,14-16]$.

Arkhangelsk region is one of RF regions with the highest share of soil samples taken in settlements that deviate from hygienic standards as per sanitary-chemical and microbi-

(C) Deryabin A.N., Unguryanu T.N., Buzinov R.V., 2019

Aleksey N. Deryabin - Chief Expert at the Sanitary Surveillance Department; a post-graduate student (e-mail: deryabinan@mail.ru; tel.: +7 (8182) 65-27-93; ORCID: https://orcid.org/0000-0002-1853-8947).

Tatiana N. Unguryanu - Doctor of Medical Sciences, Associate professor, Chief Expert at the Organization and Maintenance Department; Professor at the Department for Hygiene and Medical Ecology (e-mail: unguryanu_tn@mail.ru; tel.: +7(8182) 21-04-61; ORCID: https://orcid.org/0000-0001-8936-7324).

Roman V. Buzinov - Doctor of Medical Sciences, Associate professor, Supervisor; Professor at the Department for Hygiene and Medical Ecology (e-mail: arkh@29.rospotrebnadzor.ru; tel.: +7(8182) 20-05-69; ORCID: https:// orcid.org/0000-0002-8624-6452). 
ological parameters. In 2015-2017 a specific share of soils samples taken in settlements in the region that didn't conform to hygienic standards as per sanitary-chemical parameters amounted to $6.5 \%$ and it was 1.3 times higher than on average in the country $(5.1 \%)^{1,2}$.

The present research was performed in three big industrial cities in Arkhangelsk region (Arkhangelsk, Severodvinsk, and Novodvinsk) located in arctic zones ${ }^{3}$, namely in the northern taiga sub-zone. Arctic air makes for cold and dry weather on these territories. Average temperature in January is $-14.7^{\circ} \mathrm{C}$; in July, $+14.8^{\circ} \mathrm{C}$ [17]. Cold climate, little precipitation, and short growing season result in metals accumulation in soils [18]. Given that, it is vital to examine soil contamination with chemicals in cities located in arctic zones and impacts exerted by it on population health.

Our research goal was to comparatively analyze soil contamination with chemicals in cities located in arctic zones of Arkhangelsk region and assess population health risks caused by exposure to contaminants in soils.

Data and methods. We performed a descriptive examination of soil quality in Arkhangelsk, Severodvinsk, and Novodvinsk. Emissions from industrial enterprises were analyzed as per data collected over 2010-2015 and taken from statistic reports "2-TP Air". Soil contamination with chemicals was examined as per monitoring data collected over 2007-2017 and provided by the Center for Hygiene and Epidemiology in Arkhangelsk region. We assessed population health risks caused by exposure to chemical contaminants in soils for 10 metals: copper $(\mathrm{Cu})$, chromium
$(\mathrm{Cr})$, zinc $(\mathrm{Zn})$, nickel $(\mathrm{Ni})$, manganese $(\mathrm{Mn})$, lead $(\mathrm{Pb})$, mercury $(\mathrm{Hg})$, cadmium $(\mathrm{Cd})$, cobalt (Co), and arsenic (As). All soil samples were taken in settlements, near housing, and at children playgrounds and sport grounds.

We used median (Me) and 90-th percentile $\left(\mathrm{P}_{90}\right)$ to describe concentrations of the examined chemicals in soils and to calculate risk levels. Since distribution of chemicals concentrations statistically significantly differed from normal one, we applied Kruskal-Wallis test to compare median values and Wilcoxon twosample test to make pairwise comparison between groups. Critical level of statistical significance was taken as equal to 0.05 . We used growth rate to examine dynamics of chemicals concentrations in soils. Statistical analysis was performed with STATA 14.0.

We studied overall toxic and carcinogenic effects produced by soil contaminants on population health according to overall principles of risk assessment methodology 4 . We took the following regional values for exposure factors: body mass $(\mathrm{kg})$, duration of exposure (days per year), time spent in the open air (hours per day), duration of a contact with soil (hours per day) [19]. We assessed exposure to soil contaminants for oral and subcutaneous introduction. Risk levels were determined separately for children (age groups were 1-6 and 7-17), and adults 5,6 .

We applied reference doses to examine non-carcinogenic effects. Toxicity of contaminants was characterized basing on chronic daily introduction of a substance $(\mathrm{mg} / \mathrm{kg}$ of body mass), hazard quotients (HQ) for specific contaminants and total hazard quotients (THQ)

\footnotetext{
${ }^{1}$ On sanitary-epidemiologic welfare of the population in Russia in 2017: State report. Moscow, Federal Service for Surveillance over Consumer Rights Protection and Human Well-being Publ., 2018, 268 p.

${ }^{2}$ On sanitary-epidemiologic welfare of the population in in Arkhangelsk region in 2017: State report. Arkhangelsk, Federal Service for Surveillance over Consumer Rights Protection and Human Well-being, Arkhangelsk regional office Publ., 2018,149 p.

${ }^{3}$ Land territories in the RF Arctic zones: The RF President Order no. 296 dated May 02, 2014. KonsultantPlus. Available at: http://www.consultant.ru/document/cons doc LAW_162553/(date of visit December 10, 2018).

${ }^{4} \mathrm{P}$ 2.1.10.1920-04. Guide on assessing population health risks under exposure to chemicals that pollute the environment. Moscow, The Federal Center for State Sanitary and Epidemiologic Surveillance of RF Public Healthcare Ministry, 2004,143 p.

${ }^{5}$ Public Health Assessment Guidance Manual (Update). Atlanta, U.S. Department of Health and Human Services Public Health Service Agency for Toxic Substances and Disease Registry, 2005. Available at: http://www.atsdr.cdc.gov/ hac/phamanual/pdfs/phagm_final1-27-05.pdf (date of visit December 10, 2018).

${ }^{6}$ Supplemental guidance for developing soil screening levels for superfund sites. Washington DC: Office of Emergency and Remedial Response U.S. EPA, 2002. Available at: https://www.epa.gov/superfund/superfund-soil-screening-guidance (date of visit December 10, 2018).
} 
for specific contaminants and for all ways of introduction. We calculated hazard indexes (HI) and total hazard indexes (THI) for substances with similar effects as such indexes allowed us to assess how susceptible critical systems and organs were to these effects.

Carcinogenic effects were assessed basing on an average daily dose calculated for a lifetime $(\mathrm{mg} / \mathrm{kg} \times$ day $)$ and slope factor. We calculated the following carcinogenic risks: individual carcinogenic risk (CR) for each separate carcinogen; summary carcinogenic risk $\left(\mathrm{CR}_{\text {sum }}\right)$ for all substances for each way of introduction and for specific carcinogens introduced via all ways; total carcinogenic risk (TCR) for all the substances and ways of introduction and population carcinogenic risk (PCR) taking into account children and adult population in the examined cities.

HQ, HI, and THI values lower than 1.0 were considered to be acceptable; for carcinogenic effects, $\mathrm{CR}$ value within $1.0 \times 10^{-6}$ $1.0 \times 10^{-4}$ according to the Guide ${ }^{4}$.

Results and discussion. Soils are examined at 13 monitoring points within social and hygienic monitoring activities performed in Severodvinsk; at 17 monitoring points in Arkhangelsk; and at 9 monitoring points in Novodvinsk. On January 01, 2018 population in Archangelsk amounted to 356.9 thousand; in Severodvinsk, 184.3 thousand; in Novodvinsk, 38.4 thousand.

Over 2007-2017 23,200 soil samples were examined in all three cities and chemicals concentrations were determined in them; 1,362 samples out of them didn't conform to hygienic standards $(5.9 \%)$. The greatest specific share of samples that deviated from hygienic standards as per contaminants in them was determined in Severodvinsk during that time period $(83 \%)$. A share of soil samples taken in Severodvinsk that didn't conform to hygienic standards as per copper, chromium, zinc, nickel, lead, and arsenic, amounted to $40 \% ; 3,2 \% ; 19,1 \% ; 43 \% ; 25 \%$, and $8 \%$ respectively; as per cadmium and manganese contents, less than $1 \%$. Mercury and cobalt were detected in soils in concentrations conforming to hygienic standards.
Median concentrations of copper, zinc, nickel, and lead didn't exceed MPC in examined soil samples in Severodvinsk, but concentrations of these chemicals were higher than permissible ones at the upper exposure limit. Soil contamination with zinc, nickel, lead, and copper, taken at $\mathrm{P}_{90}$ turned out to be 1.7-4 times higher than MPC. We analyzed long-term dynamics of nickel, zinc, lead, and copper concentrations in soils taken at $\mathrm{P}_{90}$ and revealed that contamination level was growing. From 2007 to 2017 an average growth rate taken at $\mathrm{P}_{90}$ amounted to $2.3 \% ; 24.6 \%$; $25.5 \%$, and $66.3 \%$ respectively. Chromium, manganese, mercury, cadmium, cobalt, and arsenic concentrations in examined soils samples taken both at $\mathrm{Me}$ and $\mathrm{P}_{90}$ didn't deviate from permissible levels.

In Arkhangelsk a share of soil samples that contained zinc and lead in concentrations higher than MPC amounted to $7 \%$ and $6 \%$ respectively. Soil quality as per these two chemicals has deteriorated over the examined period with average growth rate at $\mathrm{P}_{90}$ level being equal to $14.7 \%$ for zinc and $0.4 \%$ for lead. A share of soil samples that contained copper, nickel, and manganese in quantities higher than MPC was lower than $1 \%$. There were no soil samples deviating from hygienic standards as per concentrations of other examined chemicals.

In Novodvinsk the highest specific weight of samples not conforming to hygienic standards was detected for copper, zinc, and lead $(1.3 \% ; 8 \%$, and $1.5 \%$ respectively). We analyzed long-term dynamics as regards concentrations of these chemicals in soils and revealed that contamination tended to increase. An average growth rate over the examined period at $\mathrm{P}_{90}$ level amounted to $41.7 \%$ for copper; $19 \%$, zinc; $4.2 \%$, lead. We didn't detect any soil samples that didn't conform to hygienic standards as per concentrations of chromium, nickel, manganese, mercury, cadmium, and cobalt. Contents of copper, chromium, zinc, nickel, manganese, lead, mercury, cobalt, and cadmium in soils taken at $\mathrm{Me}$ and $\mathrm{P}_{90}$ didn't exceed permissible levels in Arkhangelsk and Novodvinsk. 
We comparatively analyzed contents of contaminants in soils in cities located in arctic zones of Arkhangelsk region; data on contamination taken at median level revealed that soil was statistically significantly more contaminated with metals in Severodvinsk $(\mathrm{p}<0.001)$ than in tow other examined cities. Average concentrations of zinc, lead, cadmium, manganese, and mercury in soil samples taken in Severodvinsk were 5-23 times higher than contents of these metals in soils in Arkhangelsk and 3.-13 times higher than in soil in Novodvinsk. Median cobalt concentration in soil in Severodvinsk was 80 times higher than its contents in Arkhangelsk and Novodvinsk. Median copper, chromium, and nickel concentrations in soil in Severodvinsk were 7, 30, and 47 times higher than in Arkhangelsk and Novodvinsk (Table 1).

Increased metals concentrations in soil in Severodvinsk occur sue to high density of these substances contained in emissions from industrial enterprises and motor transport. Shipbuilding and machine building are the leading industries in Severodvinsk; wood processing and food industry, in Arkhangelsk; pulp and paper production, in Novodvinsk. According to data taken from "2-TP Air" report form, density of manganese, copper, and lead emissions per $1 \mathrm{~km}^{2}$ amounted to $19,3.1$ and $0.08 \mathrm{~kg}$ respectively in Severodvinsk; $0.7,0.06$, and $0.003 \mathrm{~kg}$ respectively, in Arkhangelsk; 1.2, 0.01, and $0.00006 \mathrm{~kg}$ respectively, in Novodvinsk. Zink, nickel, and chromium occurred only in emissions from industrial enterprises in Severodvinsk $(0.68,3.61$, and $0.003 \mathrm{~kg}$ respectively). As per data obtained from The Northern Office for Hydrometeorology and Environmental Monitoring, a contribution made by motor transport into ambient air contamination amounted to $57 \%$ in Arkhangelsk; 24\%, in Severodvinsk; 6\%, in Novodvinsk.

Total hazard quotients for each metal taken as a sum for oral and subcutaneous exposure didn't exceed 1.0 in all the examined cities.

We comparatively analyzed total introduced doses of chemicals that contaminated soils in Cities located in Arkhangelsk-
Severodvinsk agglomeration and revealed that dose burden for children aged 1-6 was 1.6 and 4.8 times higher respectively than doses of chemicals received by children aged 7-17 and by adults. Children aged 7-17 were exposed to 3 times higher doses of chemical toxicants in soil that adult population.

Table 1

Contents of contaminants in soils in cities located in arctic zones of Arkhangelsk region over 2007-2017

\begin{tabular}{|c|c|c|c|c|}
\hline Substance & \begin{tabular}{|c|} 
Number \\
of samples
\end{tabular} & $\mathrm{Me}^{*}$ & $\mathrm{P}_{90}$ & $\begin{array}{c}\text { MPC } \\
(\mathrm{mg} / \mathrm{kg})\end{array}$ \\
\hline \multicolumn{5}{|c|}{ Severodvinsk } \\
\hline Copper & 852 & 2.4 & 12.4 & 3.0 \\
\hline Chromium & 533 & 3.0 & 5.8 & 6.0 \\
\hline Zinc & 852 & 10.0 & 38.0 & 23.0 \\
\hline Nickel & 774 & 4.0 & 10.0 & 4.0 \\
\hline Manganese & 764 & 54.0 & 93.0 & 140.0 \\
\hline Lead & 852 & 3.1 & 10.0 & 6.0 \\
\hline Mercury & 852 & 0.05 & 0.25 & 2.1 \\
\hline Cadmium & 852 & 0.1 & 0.1 & $2.0 * *$ \\
\hline Cobalt & 764 & 2.0 & 4.0 & 5.0 \\
\hline Arsenic & 813 & 0.8 & 2.0 & 2.0 \\
\hline \multicolumn{5}{|c|}{ Arkhangelsk } \\
\hline Copper & 1109 & 0.3 & 1.01 & 3.0 \\
\hline Chromium & 1107 & 0.1 & 0.1 & 6.0 \\
\hline Zinc & 1109 & 1.9 & 18.4 & 23.0 \\
\hline Nickel & 1109 & 0.09 & 0.6 & 4.0 \\
\hline Manganese & 1109 & 2.8 & 16.2 & 140.0 \\
\hline Lead & 1109 & 0.4 & 4.4 & 6.0 \\
\hline Mercury & 1109 & 0.002 & 0.12 & 2.1 \\
\hline Cadmium & 1107 & 0.008 & 0.06 & $2.0 * *$ \\
\hline Cobalt & 1109 & 0.03 & 0.3 & 5.0 \\
\hline \multicolumn{5}{|c|}{ Novodvinsk } \\
\hline Copper & 594 & 0.3 & 1.1 & 3.0 \\
\hline Chromium & 594 & 0.1 & 0.1 & 6.0 \\
\hline Zinc & 594 & 2.9 & 21.2 & 23.0 \\
\hline Nickel & 594 & 0.09 & 0.4 & 4.0 \\
\hline Manganese & 593 & 4.1 & 16.8 & 140.0 \\
\hline Lead & 594 & 0.5 & 2.2 & 6.0 \\
\hline Mercury & 585 & 0.01 & 0.2 & 2.1 \\
\hline Cadmium & 594 & 0.01 & 0.06 & $2.0 * *$ \\
\hline Cobalt & 594 & 0.03 & 0.3 & 5.0 \\
\hline
\end{tabular}

Note:

p* means median values are compared as per Wilcoxon test $(\mathrm{p}<0.001$ for all chemicals);

$* *$ is ODC value for cadmium. 
Oral exposure is a basic one for contaminants in soil. A contribution made by oral exposure into the total dose for the examined toxicants, taken at its median level, on average amounted to $79 \%$ for children aged $1-6 ; 73 \%$, for children aged $7-17$; and $68 \%$, for adults.

Circulatory organs, blood system, central nervous system, and kidneys are organs exposed to the highest risks of overall toxic effects that are produced on population living in arctic zones under exposure to chemi- cal contaminants in soil. The liver, skin, digestive organs, reproductive and immune system occupy the second rank place in terms of exposure. We should note that a risk of non-carcinogenic effects for all the critical organs and systems didn't exceed permissible level $(\mathrm{THI}=1)$ either for children or adults (Table 2). Differences in noncarcinogenic risk levels among children and adults are due to different duration and time of exposure, body mass and body surface area [20].

Table 2

Critical organs and systems ranked as per total hazard quotients (THI) under exposure to complex introduction of chemical contaminants in soils occurring in cities located in Arkhangelsk region

\begin{tabular}{|c|c|c|c|c|c|c|}
\hline \multirow{2}{*}{ Critical organs and systems } & \multicolumn{2}{|c|}{$\begin{array}{c}\text { Children aged } \\
1-6\end{array}$} & \multicolumn{2}{|c|}{$\begin{array}{c}\text { Children aged } \\
7-17\end{array}$} & \multicolumn{2}{|c|}{ Adults } \\
\hline & $\mathrm{P}_{50}$ & $\mathrm{P}_{90}$ & $\mathrm{P}_{50}$ & $\mathrm{P}_{90}$ & $\mathrm{P}_{50}$ & $\mathrm{P}_{90}$ \\
\hline \multicolumn{7}{|c|}{ Severodvinsk } \\
\hline Circulatory organs & 0.035 & 0.064 & 0.025 & 0.045 & 0.009 & 0.016 \\
\hline Blood system & 0.033 & 0.059 & 0.023 & 0.041 & 0.008 & 0.015 \\
\hline Nervous system & 0.023 & 0.041 & 0.017 & 0.030 & 0.006 & 0.011 \\
\hline Kidneys & 0.023 & 0.041 & 0.017 & 0.030 & 0.006 & 0.011 \\
\hline Liver & 0.017 & 0.029 & 0.013 & 0.022 & 0.005 & 0.008 \\
\hline Skin & 0.013 & 0.028 & 0.009 & 0.018 & 0.003 & 0.006 \\
\hline Digestive organs & 0.006 & 0.013 & 0.004 & 0.009 & 0.002 & 0.003 \\
\hline Reproductive system & 0.006 & 0.012 & 0.004 & 0.008 & 0.002 & 0.003 \\
\hline Immune system & 0.003 & 0.009 & 0.002 & 0.007 & 0.001 & 0.003 \\
\hline \multicolumn{7}{|c|}{ Arkhangelsk } \\
\hline Circulatory organs & 0.0015 & 0.011 & 0.001 & 0.008 & 0.0004 & 0.0028 \\
\hline Blood system & 0.0015 & 0.011 & 0.001 & 0.007 & 0.0004 & 0.0027 \\
\hline Nervous system & 0.0014 & 0.011 & 0.001 & 0.008 & 0.0004 & 0.003 \\
\hline Kidneys & 0.0014 & 0.011 & 0.001 & 0.008 & 0.0004 & 0.003 \\
\hline Liver & 0.0009 & 0.005 & 0.0006 & 0.004 & 0.0002 & 0.0014 \\
\hline Digestive organs & 0.0005 & 0.006 & 0.0004 & 0.005 & 0.0001 & 0.0017 \\
\hline Reproductive system & 0.0005 & 0.006 & 0.0004 & 0.004 & 0.0001 & 0.0016 \\
\hline Skin & 0.0002 & 0.002 & 0.0001 & 0.001 & 0.0001 & 0.0004 \\
\hline Immune system & 0.0001 & 0.003 & 0.0001 & 0.002 & 0.00003 & 0.0008 \\
\hline \multicolumn{7}{|c|}{ Novodvinsk } \\
\hline Nervous system & 0.002 & 0.012 & 0.0015 & 0.0089 & 0.0006 & 0.0034 \\
\hline Kidneys & 0.002 & 0.012 & 0.0015 & 0.0089 & 0.0006 & 0.0034 \\
\hline Circulatory organs & 0.002 & 0.0095 & 0.0015 & 0.0068 & 0.0005 & 0.0025 \\
\hline Blood system & 0.002 & 0.0093 & 0.0014 & 0.0067 & 0.0005 & 0.0025 \\
\hline Liver & 0.0012 & 0.005 & 0.0009 & 0.004 & 0.0004 & 0.0015 \\
\hline Digestive organs & 0.0009 & 0.007 & 0.0006 & 0.005 & 0.0002 & 0.002 \\
\hline Reproductive system & 0.0008 & 0.007 & 0.0006 & 0.005 & 0.0002 & 0.0019 \\
\hline Immune system & 0.0003 & 0.004 & 0.0002 & 0.003 & 0.0001 & 0.0013 \\
\hline \begin{tabular}{|l|} 
Skin \\
\end{tabular} & 0.0002 & 0.002 & 0.0001 & 0.001 & 0.0001 & 0.0004 \\
\hline
\end{tabular}


Table 3

Individual, total and summary total carcinogenic risks under exposure to soil contaminants in cities located in Arkhangelsk region

\begin{tabular}{|c|c|c|c|c|c|c|}
\hline \multirow{3}{*}{ Carcinogens } & \multicolumn{4}{|c|}{ Introduction } & \multirow{2}{*}{\multicolumn{2}{|c|}{$\mathrm{CR}_{\text {sum }}$}} \\
\hline & \multicolumn{2}{|c|}{ Oral } & \multicolumn{2}{|c|}{ Subcutaneous } & & \\
\hline & $\mathrm{P}_{50}$ & $\mathrm{P}_{90}$ & $\mathrm{P}_{50}$ & $\mathrm{P}_{90}$ & $\mathrm{P}_{50}$ & $\mathrm{P}_{90}$ \\
\hline \multicolumn{7}{|c|}{ Severodvinsk } \\
\hline Nickel & $9.4 \times 10^{-5}$ & $2.4 \times 10^{-4}$ & $7.4 \times 10^{-4}$ & $1.8 \times 10^{-3}$ & $8.3 \times 10^{-4}$ & $2.1 \times 10^{-3}$ \\
\hline Lead & $4.1 \times 10^{-7}$ & $1.3 \times 10^{-6}$ & $1.3 \times 10^{-7}$ & $4.2 \times 10^{-7}$ & $5.4 \times 10^{-7}$ & $1.8 \times 10^{-6}$ \\
\hline Arsenic & $1.9 \times 10^{-5}$ & $4.7 \times 10^{-5}$ & $6.0 \times 10^{-5}$ & $1.5 \times 10^{-4}$ & $7.9 \times 10^{-5}$ & $2.0 \times 10^{-4}$ \\
\hline Cobalt & $6.3 \times 10^{-7}$ & $1.3 \times 10^{-6}$ & $2.0 \times 10^{-7}$ & $3.9 \times 10^{-7}$ & $8.3 \times 10^{-7}$ & $1.7 \times 10^{-6}$ \\
\hline $\mathrm{CR}_{\text {sum }}$ & $1.1 \times 10^{-4}$ & $2.9 \times 10^{-4}$ & $8.0 \times 10^{-4}$ & $2.0 \times 10^{-3}$ & $9.1 \times 10^{-4}$ & $2.3 \times 10^{-3}$ \\
\hline \multicolumn{7}{|c|}{ Arkhangelsk } \\
\hline Nickel & $2.0 \times 10^{-6}$ & $1.3 \times 10^{-5}$ & $1.6 \times 10^{-5}$ & $1.0 \times 10^{-4}$ & $1.8 \times 10^{-5}$ & $1.1 \times 10^{-4}$ \\
\hline Lead & $5.8 \times 10^{-8}$ & $5.9 \times 10^{-7}$ & $1.8 \times 10^{-8}$ & $1.9 \times 10^{-7}$ & $7.6 \times 10^{-8}$ & $7.8 \times 10^{-7}$ \\
\hline Cobalt & $7.9 \times 10^{-9}$ & $9.4 \times 10^{-8}$ & $2.5 \times 10^{-9}$ & $3.0 \times 10^{-8}$ & $1.0 \times 10^{-8}$ & $1.2 \times 10^{-7}$ \\
\hline $\mathrm{CR}_{\text {sum }}$ & $2.1 \times 10^{-6}$ & $1.4 \times 10^{-5}$ & $1.6 \times 10^{-5}$ & $1.0 \times 10^{-4}$ & $1.8 \times 10^{-5}$ & $1.2 \times 10^{-4}$ \\
\hline \multicolumn{7}{|c|}{ Novodvinsk } \\
\hline Nickel & $2.0 \times 10^{-6}$ & $1.0 \times 10^{-5}$ & $1.6 \times 10^{-5}$ & $8.1 \times 10^{-5}$ & $1.8 \times 10^{-5}$ & $9.2 \times 10^{-5}$ \\
\hline Lead & $6.7 \times 10^{-8}$ & $2.9 \times 10^{-7}$ & $2.1 \times 10^{-8}$ & $9.1 \times 10^{-8}$ & $8.8 \times 10^{-8}$ & $3.8 \times 10^{-7}$ \\
\hline Cobalt & $7.9 \times 10^{-9}$ & $7.9 \times 10^{-8}$ & $2.5 \times 10^{-9}$ & $2.5 \times 10^{-8}$ & $1.0 \times 10^{-8}$ & $1.0 \times 10^{-7}$ \\
\hline $\mathrm{CR}_{\text {sum }}$ & $2.1 \times 10^{-6}$ & $1.1 \times 10^{-5}$ & $1.6 \times 10^{-5}$ & $8.1 \times 10^{-5}$ & $1.8 \times 10^{-5}$ & $9.2 \times 10^{-5}$ \\
\hline
\end{tabular}

Considering median concentrations of the examined metals, in all three cities the greatest contribution into adverse effects produced on circulatory organs, blood system, nervous system, kidneys, and liver was made by manganese (48-99\%); by cadmium (39-60\%) and lead $(20-42 \%)$, on the digestive and reproductive systems; by cobalt (64-84\%), on skin; nickel $(15-65 \%)$ and mercury (33-86\%), on the immune system.

In Severodvinsk total individual carcinogenic risk for the overall population amounted to $9.1 \times 10^{-4}$ under exposure to median concentrations of carcinogens; to $2.3 \times 10^{-3}$ at 90 -th percentile. In Arkhangelsk and Novodvinsk total carcinogenic risks for the overall population were the same at median level and amounted to $1.8 \times 10^{-5}$; at 90 -th percentile, they amounted to $1.2 \times 10^{-4}$ and $9.2 \times 10^{-5}$ respectively (Table 3 ).

Total carcinogenic risk in Severodvinsk was 51 times higher at median level, and 2025 times higher at 90-th percentile level, than in Arkhangelsk and Novodvinsk. Oral introduction made the major contribution (69-70\%) into carcinogenic risks occurrence in the examined cities. The greatest contribution into summary total carcinogenic risk was made by nickel (from 91 to 99\%). Population carcinogenic risk taken over 70 years under exposure to carcinogens in soil amounted to 2.4 at median level in Severodvinsk; to 0.09 , in Arkhangelsk; to 0.001 , in Novodvinsk. There were 0.03 annual additional cases of malignant neoplasms among population in Severodvinsk caused by carcinogens in soils.

Conclusion. Soil in housing areas in Severodvinsk contains the highest concentrations of metals in comparison with other cities located in arctic zones of Arkhangelsk region. It is due to emissions from industrial enterprises dealing with shipbuilding and machine building.

Carcinogenic and non-carcinogenic risks under exposure to chemical contaminants in soil are higher in Severodvinsk than in two other examined cities; they are permissible when taken at median concentrations. Carcinogenic risk taken at 90-th percentile is higher than permissible values; it is subject 
to permanent control and requires developing a set of activities aimed at reducing soil contamination with chemicals. These activities should include improved production technologies that can ensure smaller emissions and discharges of adverse substances into the environment; new enterprises on wastes recycling and processing; construc- tion and reconstruction of sewage disposal plants; detection and lamination of contamination sources.

Funding. The research was not granted any financial support.

Conflict of interests. The authors declare there is no any conflict of interests.

\section{References}

1. Tafeeva E.A., Ivanov A.V., Titova A.A., Petrov I.V. Content of heavy metals and petroleum products in the soil on the territory of oil-producing areas of the Republic of Tatarstan. Gigiena i sanitariya, 2016, vol. 95, no. 10, pp. 939-941 (in Russian).

2. Deryabin A.N., Unguryanu T.N. Assessment of biological pollution of soil in the Arkhangelsk Region. Zdorov'e naseleniya i sreda obitaniya, 2017, vol. 292, no. 7, pp. 18-21(in Russian).

3. Vodyanova M.A., Kriatov I.A., Donerian L.G., Evseeva I.S., Ushakov D.I., Sbitnev A.V. Ecological hygienic assessment of soils quality in urban areas. Gigiena i sanitariya, 2016, vol. 95, no. 10, pp. 913-916 (in Russian).

4. Ivanov S.A., Dmitrieva O.F., Kulmakova N.I., Dimitriev Yu. O. Soil pollution from toxins of the Volga river shoreland in the area of Cheboksary hydropower station. Ekologiya cheloveka, 2016, no. 5, pp. 3-8 (in Russian).

5. Benhaddya M., Boukhelkhal A., Halis Y., Hadjel M. Human health risks associated with metals from urban soil and road dust in an oilfield area of Southeastern Algeria. Archives of Environmental Contamination and Toxicology, 2016, vol. 70, no. 3, pp. 556-571. DOI:10.1007/s00244-015-0244-6

6. Sardar K., Sadaf M., Muhammad S., Gang L. Urban park soil contamination by potentially harmful elements and human health risk in Peshawar City, Khyber Pakhtunkhwa, Pakistan. Journal of Geochemical Exploration, 2016, vol. 165, pp. 102-110. DOI: 10.1016/j.gexplo.2016.03.007

7. Tilekova Z.T., Tonkopii M.S., Tastanova B.E. Evaluation of soil pollution by heavy metals in Balkhash region. Fundamental'nye issledovaniya, 2015, no. 2, pp. 3723-3726 (in Russian).

8. Kolnet I.V., Studenikina E.M. Organization of monitoring of soil pollution level for risk assessment to child health. Nauchno-meditsinskii vestnik Tsentral'nogo Chernozem'ya, 2017, no. 70, pp. 100-105 (in Russian).

9. Kazantsev I.V., Matveeva T.B. Contents of heavy metals in the soil cover in the conditions of technogenesis. Samarskii nauchnyi vestnik, 2016, vol. 14, no. 1, pp. 34-37 (in Russian).

10. Sintsov A.V., Barmin A.N., Valov M.V. Dynamics of heavy metals in urboecosystems' soils. Geologiya, geografiya i global'naya energiya, 2014, vol. 55, no. 4, pp. 148-156 (in Russian).

11. Cai L.M., Xu Z.C., Qi J.Y., Feng Z.Z., Xiang T.S. Assessment of exposure to heavy metals and health risks among residents near Tonglushan mine in Hubei, China. Chemosphere, 2015, vol. 127, pp. 127-135. DOI: 10.1016/j.chemosphere.2015.01.027

12. Shcherbakov A.V., Shcherbakova V.N. Vliyanie na zdorov'e cheloveka zagryazneniya pochv. [Impacts exerted on human health by soil contamination]. Aktual'nye problem estestvenno-nauchnogo obrazovaniya, zashchity okruzhayushchei sredy i zdorov'ya cheloveka: materialy IV Mezhdunarodnoi ochnoi nauchno-prakticheskoi konferentsii. Orel, Izdatel'stvo Orlovskogo gosudarstvennogo universiteta im. I.S. Turgeneva Publ., 2016, vol. 4, no. 4, pp. 424-426 (in Russian).

13. Teplaya G.A. Heavy metals as a factor of environmental pollution (review). Astrakhanskii vestnik ekologicheskogo obrazovaniya, 2013, vol. 23, no. 1, pp. 182-192 (in Russian).

14. Sardar K., Hameed S., Afzal S., Fatima S., Shakoor M., Bharwana S., Tauqeer H. Heavy Metals Contamination and what are the Impacts on Living Organisms. Greener Journal of Environmental Management and Public Safety, 2013, vol. 2 no. 4, pp. 172-179.

15. Ermolaeva S.V., Lavrushina E.E., Kurgaeva A.V. Assessment of soils pollution by heavy metals at territories of Ulyanovsk oblast. Izvestiya Samarskogo nauchnogo tsentra Rossiiskoi akademii nauk, 2013, vol. 15, no. 3 (3), pp. 978-980 (in Russian). 
16. Nikolaeva A.D. Ekologicheskie aspekty zagryazneniya pochv tyazhelymi metallami [Ecological aspects related to soil contamination with heavy metals]. Tatishchevskie chteniya. Aktual'nye problemy nauki i praktiki: materialy XIV mezhdunarodnoi nauchno-prakticheskoi konferentsii. Tol'yatti, Volzhskii universitet imeni V.N. Tatishcheva, 2017, vol. 1, pp. 231-235 (in Russian).

17. Buzinov R.V., Kiku P.F., Unguryanu T.N., Yarygina M.V., Gudkov A.B. Ot Pomor'ya do Primor'ya: sotsial'no-gigienicheskie i ekologicheskie problem zdorov'ya naseleniya: monografiya [From the Pomorye to the Prymorye: social-hygienic and ecological issues related to human health: a monograph]. Arkhangelsk, Izdatelstvo Severnogo gosudarstvennogo meditsinskogo universiteta Publ., 2016, 397 p. (in Russian).

18. Krasnoshchekov Yu.N. Microelements in the soils of the central Khangay pseudo-taiga larch forests in Mongolia. Sbornik materialov Vserossiiskoi nauchnoi konferentsii s mezhdunarodnym uchastiem, posvyashchennoi 50-letiyu Instituta pochvovedeniya i agrokhimii Sibirskogo otdeleniya RAN. In: A.I. Syso ed. Tomsk, 2018, pp. 47-51(in Russian).

19. Unguryanu T.N., Novikov S.M. Approaches to assessing the health risk under exposure to chemicals with account of age peculiarities. Gigiena i sanitariya, 2012, vol. 91, no. 5, pp. 98-101 (in Russian).

20. Unguryanu T.N., Gudkov A.B., Nikanov A.N. Health risk assessment of soil contaminants for health of urban population. Profilakticheskaya i klinicheskaya meditsina, 2012, no. 1, pp. 101-105 (in Russian).

Deryabin A.N., Unguryanu T.N., Buzinov R.V. Population health risk caused by exposure to chemicals in soils. Health Risk Analysis, 2019, no. 3, pp. 18-25. DOI: 10.21668/health.risk/2019.3.02.eng

Received: 27.03.2019

Accepted: 26.07 .2019

Published: 30.09.2019 
UDC 617.753.2

DOI: $10.21668 /$ health.risk/2019.3.03.eng

\title{
ANALYSIS OF RISK FACTORS THAT CAUSE MYOPIA IN PRE-SCHOOL CHILDREN AND PRIMARY SCHOOL STUDENTS
}

\author{
E.P. Tarutta, O.V. Proskurina, N.A. Tarasova, G.A. Markosyan
}

Helmholtz's National Medical Research Center of Eye Diseases, 14/19 Sadovaya-Chernogryazskaya Str., Moscow, 105062, Russian Federation

The article summarizes literature data on significant risk factors that cause myopia in children; it also dwells on an algorithm that can be applied by ophthalmologists, pediatricians, family doctors, and medical optometrists to determine risk groups as per myopia, to accomplish dynamic observation, and to implement medical and prophylaxis activities aimed at its prevention. A hereditary factor in myopia development is considered to be the most significant one. There are also several other significant factors such as refraction being greater than +0.75 diopter at an age 6-10; an anterior-posterior axis of the eye being longer than $23.5 \mathrm{~mm}$; pseudo-myopia; relative accommodation resources being lower than 1.0 diopter; axial length over cornea radius ratio $(A L / C R)$ being higher than 3; accommodative convergence over accommodation ratio (AC/A) being higher than 4 pr.diopter / diopter; relative peripheral hypermetropia and off-axis refraction asymmetry when the nasal side of the eye is higher than the temporal one. We paid special attention to influences exerted by the environment and urbanization. High educational and social status of a family results in elevated risks of myopia. We also spotted out several risk factors that could be eliminated; they were hypodynamia under great visual loads and a period of time spent outdoors being shorter than 10 hours a week. Reliable preventive measures include parents' control over visual activities of a child; imposing limits on visual loads; outdoor activities for not less than 10-14 hours a week; physical exercises and doing some sports; home training to improve accommodation; correction aimed at compensating peripheral hypermetropia and lor inducing myopic defocus; local medical treatment. Early detection of risk factors and direct or indirect influence on them allow preventing myopia or postponing its development for an older age; it results in lower frequency of significant myopia and reduces a number of complicated and severe myopia cases.

Key words: myopia in children, risk factors, myopia development, myopia prevention, myopia predictors, refraction disorders, peripheral refraction.

Myopia is the most common type of disproportionate refraction; it is more frequently an acquired disorder. Myopia usually develops when a child starts school but its earlier occurrence in children - during preschool years - becomes more and more frequent $[1,2]$. Frequency of myopia differs substantially across the world. This type of refraction is most frequently detected in countries located in South-Eastern Asia where prevalence of myopia exceeds $90 \%$ as per data taken from several sources $[3,4]$. In Europe myopia is not so widely spread but still its prevalence among population is greater than 35\% [5]. In some regions in Russia $2.4 \%$ children are already near-sighted when they just start school. By the fifth grade a number of near-sighted children grows by 8 times (!) reaching 19.7\%. By the last school year prevalence of myopia among schoolchildren is close to average European level and amounts to $36.8 \%$ [2]. There is even a

(C) Tarutta E.P., Proskurina O.V., Tarasova N.A., Markosyan G.A., 2019

Elena P. Tarutta - Doctor of Medical Sciences, Professor, Head of the Department for Refraction Pathologies, Binocular Eyesight, and Ophthalmologic Ergonomics (e-mail: kanc@igb.ru; tel.: +7 (495) 608-42-00; ORCID: https://orcid.org/0000-0002-8864-4518).

OI ga V. Proskurina - Doctor of Medical Sciences, Leading Researcher at the Department for Refraction Pathologies, Binocular Eyesight, and Ophthalmologic Ergonomics (e-mail: proskourina@mail.ru; tel.: +7 (916) 169-11-14; ORCID: https://orcid.org/00000002-2496-2533).

Natalya A. Tarasova - Candidate of Medical Sciences, Senior Researcher at the Department for Refraction Pathologies, Binocular Eyesight, and Ophthalmologic Ergonomics (e-mail: kanc@igb.ru;tel.: +7 (495) 608-42-00; ORCID: https://orcid.org/0000-0002-3164-4306).

Gayane A. Markosyan - Doctor of Medical Sciences, Leading Researcher at the Department for Refraction Pathologies, Binocular Eyesight, and Ophthalmologic Ergonomics (e-mail: kanc@igb.ru; tel.: +7 (495) 608-42-00; ORCID: https://orcid.org/0000-0002-2841-6396). 
concept stating that there is "epidemic of myopia" $[3,4]$. The WHO program 'Control and prevention of blindness and deafness by 2020 " determines myopia as one of five priority diseases that require active prevention of eliminable blindness.

Meta-analysis performed by Brien Holden Vision Institute on 2.1 million participants revealed that there should be a significant rise in a number of short-sighted people all over the world from 2000 to 2050. As predicted, by 2050 there will be 4.8 billion short-sighted people in the world or, in other words, $49.8 \%$ of the overall world population. And almost 1 billion people will suffer from high myopia [6]. Myopia causes 3 times higher risks of early acquired cataract; 8 times higher risks of retina rapture; 18 times higher risks of glaucoma [7]. And if myopia develops at an early age, it is the most established factor for consequent occurrence of high myopia $[1,8]$.

Although all contemporary techniques aimed at controlling myopia are quite efficient, a greater attention should be paid to detecting risk factors that cause myopia in preschool and junior school children if we want to prevent its spread. It is also very important to prevent its development, especially at early stages of the disease.

This paper focuses on generalizing all the available literature data on risk factors that cause myopia and their ranking; there is an algorithm which we recommend to ophthalmologists, pediatricians, family doctors, and medical optometrists as they can apply it to create risk groups as per myopia, to perform dynamic observation, and to implement relevant treatment and prophylaxis aimed at preventing myopia.

There are a lot of scientific works, especially by foreign authors, that concentrate on determining risks of myopia occurrence in children. We thoroughly analyzed these works and it allowed us to reveal the most significant and convincing factors that cause risks of myopia.

Heredity. It is quite possible that a child becomes near-sighted even if he or she doesn't have any relatives (parents or more remote ones) who suffer from myopia. Chances that such children might have myopia are equal to 0.28 ; but if both parents of a child are nearsighted, chances grow to 0.85 and continue to increase with each subsequent generation [9]. Obviously, the reverse situation is also possible when near-sighted parents have children with normal vision but it is rather rare. A simple calculation shows that chances for it are equal to not more than 0.12 . It is heredity that makes a significant contribution into probability of myopia occurrence. Thus, a child who has at least one near-sighted parent runs 2-3 times higher risks of myopia than a child whose parents have normal vision. Most researchers confirm that having two near-sighted parents causes 1.5-2 times higher risk of myopia for their children [1,8,9, and 10].

Sex. We haven't found any convincing data on a sex being a factor that can cause elevated risks of myopia.

Ethnic groups. Multiple research works prove that prevalence of myopia is significantly higher among people coming from Eastern Asia, notably Chinese, than among Europeans (Caucasians) and other ethnic groups [1, 3, 4, 5, and 11].

The environment, education, and urbanization. There are a lot of convincing evidences that there is a tight correlation between genetic factors and impacts exerted by the environment [1, 3, and 10]. Experts comparatively analyzed refraction of Sherpa children who lived in rural areas and children from Tibet who lived in Katmandu (the capital of Nepal); those children had the same ancestors but lived in drastically different educational and ecological conditions. The analysis revealed that myopia was considerably less frequent among Sherpa children $(2.9 \%)$ than among their counterparts living in a city $(21.7 \%)$ [12]. We may state that high prevalence of myopia results from adaptation to impacts exerted by ecological changes, better education that is indirectly linked to a higher social and economic status, and urbanization $[1,3,13]$. The latter 
in its turn is linked to many environmental factors that produce direct or indirect effects on prevalence of myopia. Researchers examined factors that caused myopia among Chinese children and revealed that multi-factor and polygenic models prevailed in the process and genetic factors remained constant in them whereas influence exerted by the environment had been growing during lives of the last three generations [10]. Myopia prevalence remained the same in different ethnic groups exposed to the same environmental conditions in spite of significant genetic differences.

Time a child spends outdoors, duration of work at a short distance, sight hygiene, and family. Recent research confirms the result obtained via previous one performed by E.S. Avetisov [14]: if children spend sufficient amount of time outdoors, it reduces risks of myopia. The most significant factor here is a balance between time a child spends on working at a short distance from objects and time he or she spends outdoors [3, 15]. Thus, 12-year old children who spend less than 1.6 hours outdoors a day and have additional 3 hours of educational loads beyond school acquire myopia 2-3 times more frequently than children of the same age who spend more than 2.8 hours outdoors and with additional educational loads being less than 2 hours [16]. A simple change in a day schedule - children spending their breaks outdoors - leads to a more than a 2-time reduction in risks of myopia among children aged $7-11$ as calculated risks of myopia amounted to $8.41 \%$ among children who spent their school breaks outdoors and to $17.65 \%$ among those who didn't do it [17]. To sum up, increased amount of time spent outdoors leads to a 2-time reduction in risks of myopia as well as makes for slower development of already existing myopia [18]. Some authors state that physical activities and doing sports outdoors during 7-14 hours a week is quite a reliable factor that can prevent myopia occurrence $[19,20]$. Children aged 7-9 who read two or more books a week run a three times higher risk of myopia as compared to those children who read two or fewer books a week [21, 22]. Children aged 12-13 who hold a book at a distance equal to $29 \mathrm{~cm}$ or less when reading run 2.5 times higher risk of myopia; uninterrupted reading that lasts for longer than 30 minutes results in 1.5 times higher risks of myopia [21]; 6-year old children who work at a short distance from objects for more than 1 hour a day run 1.26 times higher risk of myopia [23]. However, if we take into account other significant factors (such as belonging to a specific ethnic group, for example), we should specify that intensity is a leading factor and not a period of time spent working at a short distance from objects. Children who suffered from myopia were compared with children who had normal vision; it turned out that near-sighted children more frequently had near-sighted parents; they spent much more time on educational tasks, more time on reading, and less time on doing sports; they tended to have higher scores in reading ITBS tests and overall language sub-tests [24]; they attended grammar schools; they watched TV or played computer games, videogames or games on their smartphones for more than 2 hours a day; their families had higher social status [19]. Our previous research also revealed that myopia was much more frequent among children who attended specialized grammar schools as compared to those who attended "ordinary" comprehensive schools [2].

Greater attention paid by parents to visual activities of their children can substantially reduce risks of myopia occurrence. Control over use of electronic devices resulted in more than 2-rtime decrease in risks of myopia. Other significant factors were control over a child getting sufficient amount of sleep, a posture he or she took when doing homework, and amount of time a child spent outdoors. The earlier parents started to pay attention to those factors the lower was risk of myopia for their children at an early age and the better were refraction and functional results at an older age [13]. 
Axial refraction. Data collected via observation cohort study revealed that cycloplegic sphere equivalent of refraction that is stronger than 0.75 diopter hypermetropia in children younger than 6 is the most authentic predictor that myopia will occur in future, the probability being 95\%. Refraction that is stronger than 0.5 diopter hypermetropia is a myopia predictor for 6-year old children; emmetropia is a predictor for children aged 7-8 [25]. According to some other data, hypermetropia that is lower than 0.75 diopter is a real risk factor that causes myopia in children up to 11 years of age $[8,11]$. Refractometry data in case there is cycloplegia can be a sufficient ground for including a child into a risk group as per myopia.

Axial length of an eye and refracting power of the cornea. Axial length that is greater than $23.5 \mathrm{~mm}$ correlates with high risks of myopia among 6-year old children with normal vision regardless of their genetic background [11]. Anterior-posterior axis length that is greater than $24.33 \mathrm{~mm}$ can be a risk factor that causes myopia among children aged 10-14 [26]. Axial length (mm) over cornea radius $(\mathrm{mm})$ ratio $(\mathrm{AL} / \mathrm{CR})$ that is higher than 3 can be a more reliable predictor of myopia occurrence among children aged 6-12 [27]. Radius of horizontal meridian curvature is more informative in such calculations.

Off-axis refraction (peripheral refraction) and length of an eye. Initial form of an eye can be a risk factor that causes myopia. Relative peripheral hypermetropic refraction is considered a reliable myopia predictor as children who acquired myopia tended to have more significant relative peripheral hypermetropia $2-5$ years prior to becoming nearsighted that those who preserved normal vision $[11,25]$. There was a study that concentrated on contours of the retina via determining a discrepancy between axial and off-axis length of an eye in a $20^{\circ}$ zone; 140 children aged from 7 to 11 were examined twice with a 30-month interval between two checkups. The study revealed a significant correlation between myopia occurrence and initially steeper contour of the retina from the temporal side. Steeper contour of the retina from the temporal side implies there is relative peripheral long sight in this part of the retina or weaker refraction in the temporal zone as compared with the nasal one [28]. A difference in an extent to which the nasal and temporal parts of an eye contribute into myopia occurrence is confirmed by measurement of off-axis refraction during accommodation. Off-axis refraction in $40^{\circ}$ zone in the retina of a short-sighted eye changes weaker than in an eye with normal vision by 1.1 diopter in the nasal zone and by 1.7-2.0 diopter in the temporal one during accommodation tasks that are performed at $25 \mathrm{~cm}$ distance. Risks of myopia are assumed to grow if an eye doesn't change retina curvature when performing its tasks [29].

Accommodation. Weaker accommodation response can be treated as an independent myopia predictor [30, 31, and 32]. Special attention is paid to a low-bent head when any task is performed at a close distance $[14,21]$ and a decrease in relative accommodation resources: children who later acquired myopia had lower relative accommodation resources (1.46 diopter) than those who preserved their normal vision (2.04 diopter) [32].

Pseudomyopia is a symptom that is considered to be a specific myopia predictor by mostly Russian researchers. The Expert Council on Accommodation and Refraction (ECAR) determines pseudomyopia as a state when manifest refraction is emmetropic, and cycloplegic refraction is either emmetropic or even hypermetropic. A.I. Dashevskiy (1988) believed that pseudomyopia always preceded actual near-sightedness [33]. Pseudomyopia occurrence leads to 3.03 times higher risks of myopia and it preceded axial myopia in $77.8 \%$ of children who had it [26].

Heterophoria and $\mathrm{AC} / \mathrm{A}$ ratio. Heterophoria which is higher than 3 prism diopter (pr.diopetr) is an obvious risk factor that can cause myopia in children; greater attention here is paid to esophoria $[32,34]$. Accom- 
modative convergence over accommodation $(\mathrm{AC} / \mathrm{A})$ ratio is more informative in this respect. An increase in AC/A ratio can be detected 4 years prior to myopia occurrence and is equal to 7 pr.diopter/diopter in children who run high risks of myopia occurrence. This ratio is authentically lower in children who will potentially preserve their normal vision and remains equal to 4 pr.diopter/ diopter; it is probably due to a greater lag in accommodation in children who can become near-sighted [34]. Previous research revealed that risk of myopia occurrence grew by 22.5 times during 1 year for children with $\mathrm{AC} / \mathrm{A}$ ratio being equal to 5.84 pr.diopter/ diopter and higher; if they also had their axial refraction being equal to +0.75 and even more, risks additionally increased by 3.21 times [35]. Increased AC/A ratio as a risk factor that caused myopia was also mentioned during the following 1-4 years in other research works.

Intraocular pressure. We haven't found any convincing facts that intraocular pressure exerts any influence on myopia occurrence.

There are some other factors mentioned in scientific literature that can cause myopia; they are thickness and refracting power of the lens [25], size and type of astigmatism $[25,26]$, spherical aberration sign and some others.

If myopia is prevented or at least its occurrence is postponed, it can reduce risks of high myopia occurrence $[1,8]$. As is known, the later myopia develops the smaller its ultimate value is $[26,36]$, and any impacts exerted on myopic process with 33\% efficiency reduce frequency of high myopia by $73 \%$; $50 \%$ efficiency will result in a $90 \%$ decrease in frequency of high myopia [36].

Obviously, myopia among children should be dealt with; it is necessary to start from detecting and analyzing risk factors that cause its development among pre-school and junior school children. Certain risk factors that cause myopia such as heredity and anterior-posterior axis length can't be changed or eliminated. Others, such as too little time spent outdoors or considerably long and intense visual loads when working at a close distance can be removed. Prolonging time spent by children outdoors up to 10-14 hours per week, doing sports, additional educational loads being limited to 2 hours a day or less are efficient measures that can prevent myopia $[16,17,19$, and 20]. They are especially relevant for children whose parents have myopia in their case histories. Parents should control visual activities of their children, how their children use gadgets, how much time they spend watching TV, what postures they take when working at a close distance, how long their sleep is or whether they get enough rest; all these measures allow achieving more than a 2-times reduction in risks of myopia occurrence [13].

Central and peripheral refraction, accommodation, convergence and their interrelations as well as some other factors can be influenced via perifocal optical correction that corrects relative peripheral long sight [37]; via correction that compensates for insufficient accommodation and induces a myopic defocus in an eye [38]; training accommodation including special training glasses that can be used at home [39]; applying local drug therapy with $\alpha$-adrenoceptor antagonists, M-cholinergic antagonists and their combinations [40].

Conclusion. Myopia becomes more and more frequent with each subsequent generation. Overall trend is that a number of people with myopia is growing all over the world including those suffering from high myopia.

The most significant factors that cause myopia are heredity (especially if both parents are short-sighted or one of them suffers from high myopia), pseudomyopia, refraction that is stronger than 0.75 diopter hypermetropia, greater anterior-posterior axis length, and high AC/A ratio. Significant influence is also exerted by environmental factors, education, and urbanization. There are a lot of convincing evidences that there is a tight correlation between genetic factors and impacts exerted by the environment. Behav- 
ioral factors are also very important; they include time spent actively outdoors, length and intensity of visual loads when working at a close distance.

It is vital to early detect risk factors and influence them directly or indirectly as it allows preventing myopia occurrence or postpone it for an older age. It, in its turn, will lead to high myopia becoming less frequent, reducing cases in which myopia gets complicated or turns into a grave form.

Funding. The research was not granted any sponsor support.

Conflict of interests. The authors state there is no any conflict of interests.

\section{References}

1. Wojciechowski R. Nature and nurture: the complex genetics of myopia and refractive error. Clin. Genet, 2011, vol. 79, no. 4, pp. 301-320. DOI: 10.1111/j.1399-0004.2010.01592.x

2. Proskurina O.V., Markova E.Y., Brzheskij V.V., Efimova E.L., Efimova M.N., Chvatova N.N., Slychalova N.N., Egorova A.V. Prevalence of Myopia in Schoolchildren in Some Regions of Russia. The Ophthalmology in Russia, 2018, vol. 15, no. 3, pp. 348-353 (in Russian). DOI: 10.18008/1816-5095-2018-3-348-353

3. Foster P.J., Jiang Y. Epidemiology of myopia. Eye (Lond), 2014, vol. 28, no. 2, pp. 202-208. DOI: $10.1038 /$ eye.2013.280

4. Morgan I.G., French A.N., Ashby R.S., Guo X., Ding X., He M., Rose K.A. The epidemics of myopia: Aetiology and prevention. Prog. Retin. Eye Res, 2018, vol. 62, no. 1, pp. 134-149. DOI: 10.1016/j.preteyeres.2017.09.004

5. Wolfram C., Höhn R., Kottler U., Wild P., Blettner M., Bühren J., Pfeiffer N., Mirshahi A. Prevalence of refractive errors in the European adult population: the Gutenberg Health Study (GHS). Br. J.Ophthalmol, 2014, vol. 98, no. 7, pp. 857-861. DOI: 10.1136/bjophthalmol-2013-304228

6. Holden B.A., Fricke T.R., Wilson D.A., Jong M., Naidoo K.S., Sankaridurg P., Wong T.Y., Naduvilath T.J., Resnikoff S. Global prevalence of myopia and high myopia and temporal trends from 2000 through 2050. Ophthalmology, 2016, vol. 123, no. 5, pp. 1036-1042. DOI: 10.1016/j.ophtha.2016.01.006

7. Tano Y. Pathologic myopia: where are we now? Am. J. Ophthalmol, 2002, vol. 134, no. 5, pp. 645-660. DOI: 10.1016/S0002-9394(02)01883-4

8. Jones-Jordan L.A., Sinnott L.T., Manny R.E., Cotter S.A., Kleinstein R.N., Mutti D.O, Twelker J.D., Zadnik K. [et al.]. Early childhood refractive error and parental history of myopia as predictors of myopia. Invest. Ophthalmol. Vis. Sci, 2010, vol. 51, no. 1, pp. 115-121. DOI: 10.1167/iovs.08-3210

9. Wu M.M., EdwardsM.H. The effect of having myopic parents: an analysis of myopia in three generations. Optom. Vis Sci, 1999, vol. 76, no. 6, pp. 387-392.

10. Zadnik K., Satariano W.A., Mutti D.O., Sholtz R.I., Adams A.J. The effect of parental history of myopia on children's eye size. JAMA, 1994, vol. 271, no. 17, pp. 1323-1327.

11. Mutti D.O., Hayes J.R., Mitchell G.L., Jones L.A., Moeschberger M.L., Cotter S.A., Kleinstein R.N., Manny R.E., Twelker J.D., Zadnik K. [et al.]. Refractive error, axial length, and relative peripheral refractive error before and after the onset of myopia. Invest. Ophthalmol. Vis. Sci, 2007, vol. 48, no. 6, pp. 2510-2519. DOI: 10.1167/iovs.06-0562

12. Garner L.F., Owens H., Kinnear R.F., Frith M.J. Prevalence of myopia in Sherpa and Tibetan children in Nepal. Optom. Vis. Sci, 1999, vol. 76, no. 5, pp. 282-285.

13. Zhou S., Yang L., Lu B., Wang H., Xu_T., Du D., Wu S., Li X., Lu M. Association between parents' attitudes and behaviors toward children's visual care and myopia risk in school-aged children (meta-analis). Medicine, 2017, vol. 96, no. 52, pp. e9270. DOI: 10.1097/MD.0000000000009270

14. Avetisov E.S. Blizorukost': monografiya [Myopia: a monograph]. Moscow, Meditsina Publ., 1999,186 p. (in Russian).

15. Gray C., Gibbons R., Larouche R., Sandseter E.B.,Bienenstock A., Brussoni M., Chabot G., Herrington S. [et al.]. What is the relationship between outdoor time and physical activity, sedentary behaviour, and physical fitness in children? A systematic review. Int. J. Environ Res. Public Health, 2015, vol. 12, no. 6, pp. 6455-6474. DOI: 10.3390/ijerph120606455 
16. Rose K.A., Morgan I.G., Ip_J., Kifley_A., Huynh S., Smith W., Mitchell P. Outdoor activity reduces the prevalence of myopia in children. Ophthalmogy, 2008, vol. 115, no. 8, pp. 1279-1285. DOI: $10.1016 /$ j.ophtha.2007.12.019

17. Wu P.C., Tsai C.L., Wu H.L., Yang Y.H., Kuo H.K. Outdoor activity during class recess reduces myopia onset and progression in school children. Ophthalmology, 2013, vol. 120, no. 5, pp. 1080-1085. DOI: 10.1016/j.ophtha.2012.11.009

18. Deng L., Pang Y. Effect of outdoor activities in myopia control: meta-analysis of clinical studies. Optom. Vis Sci,_2019, vol. 96, no. 4, pp. 276-282. DOI: 10.1097/OPX.0000000000001357

19. Saxena R., Vashist_P., Tandon_R., Pandey R.M., Bhardawaj A., Menon V., Mani K. Prevalence of myopia and its risk factors in urban school children in Delhi: the North India Myopia Study (NIM Study). PLoS One, 2015, vol.10, no. 2, pp. e0117349. DOI: 10.1371/journal.pone.0117349

20. Rose K.A., Morgan I.G., Smith W., Burlutsky_G., Mitchell P., Saw S.M. Myopia lifestyle and schooling in students of Chinese ethnicity in Singapore and Sydney. Arch. Ophthalmol, 2008, vol. 126, no. 4, pp. 527-530. DOI: 10.1001/archopht.126.4.527

21. Huang H.M., Chang D.S.T., Wu P.C. The Association between near work activities and myopia in children - a systematic review and meta-analysis. PLOS ONE, 2015, vol. 10, no. 10, pp. e0140419. DOI: 10.1371 journal.pone.0140419

22. Saw S.M., Chua W.H., Hong C.Y., Wu H.M., Chan W.Y., Chia K.S., Stone R.A., Tan D. Nearwork in early-onset myopia. Invest. Ophthalmol. Vis. Sci, 2002, vol. 43, no. 2, pp.332-339.

23. Holton V., Hinterlong_J.E., Tsai C.Y., Tsai J.C., Wu J.S., Liou_Y.M. A nationwide study of myopia in taiwanese school children: family, activity, and school-related factors. J. Sch. Nurs, 2019, vol. 13, p. 1059840519850619 . DOI: $10.1177 / 1059840519850619$

24. Mutti D.O., Mitchell G.L., Moeschberger M.L., Jones L.A., Zadnik K. Parental myopia, near work, school achievement, and children's refractive error. Invest. Ophthalmol. Vis. Sci., 2002, vol. 43 , no. 12 , pp. $3633-3640$.

25. Zadnik K., Sinnott L.T., Cotter S.A., Jones-Jordan L.A., Kleinstein R.N., Manny R.E., Twelker J.D., Mutti D.O. [et al.]. Prediction of juvenile-onset myopia. JAMA Ophthalmol, 2015, vol. 133, no. 6, pp. 683-689. DOI: 10.1001/jamaophthalmol.2015.0471

26. Onufriychuk O.N., Rozenblum Yu.Z. Regularities of the refractive genesis of school myopathy and criteria for its prediction. Vestnik oftal'mologii, 2007, no. 6, pp. 22-24.

27. He X., Zou H., Lu L., Zhao R., Zhao H., Li Q., Zhu J. Axial length/corneal radius ratio: association with refractive state and role on myopia detection combined with visual acuity in Chinese schoolchildren. PLoS One, 2015, vol. 10, no. 2, pp. e0111766. DOI: 10.1371/journal.pone.0111766

28. Schmid G.F. Association between retinal steepness and central myopic shift in children. Opt. Vis. Sci, 2011, vol. 88, no. 6, pp. 684-690. DOI: 10.1097/OPX.0b013e3182152646

29. Lundström L., Mira-Agudelo A., Artal P. Peripheral optical errors and their change with accommodation differ between emmetropic and myopic eyes. Journal of vision, 2009, vol. 9, no. 6, pp. 1-11. DOI: 10.1167/9.6.17

30. Mutti D.O., Mitchell G.L., Hayes J.R., Jones L.A., Moeschberger M.L., Cotter S.A., Kleinstein R.N., Manny R.E. [et al.]. Accommodative lag before and after the onset of myopia. Invest. Ophthalmol Vis Sci, 2006, vol. 47, pp. 837-846. DOI: 10.1167/iovs.05-0888

31. Charman W.N. Near vision, lags of accommodation and myopia. Ophthalmic Physiol. Opt., 1999, vol. 19, no. 2, pp. 126-133.

32. Goss D.A., Jackson T.W.Clinical findings before the onset of myopia in youth: 2. Zone of clear single binocular vision. Optom. Vis. Sci, 1996, vol. 73, no. 4, pp. 263-268.

33. Dashevskii A.I. Razvitie psevdomiopii i miopii i ikh profilaktika [Myopia and pseudomyopia: development and prevention]. Vestnik oftal'mologii, 1988, no. 3, pp. 132-136 (in Russian).

34. Sreenivasan V., Irving E.L., Bobier W.R. Effect of heterophoria type and myopia on accommodative and vergence responses during sustained near activity in children. Vision Research, 2012, vol. 57, pp. 9-17. DOI: 10.1016/j.visres.2012.01.011

35. Mutti D.O., Mitchell G.L., Jones-Jordan L.A., Cotter S.A., Kleinstein R.N., Manny R.E., Twelker J.D., Zadnik K. [et al.]. The response AC/A ratio before and after the onset of myopia. Invest. Ophthalmol. Vis. Sci, 2017, vol. 58, no. 3, pp. 1594-1602. DOI: 10.1167/iovs.16-19093 
36. Brennan N.A. Predicted reduction in high myopia for various degrees of myopia control. Cont. Lens Anterior Eye, 2012, vol. 35, no. 1, pp. 14-15. DOI: 10.1016/j.clae.2012.08.046

37. Ibatulin R.A., Proskurina O.V., Tarutta E.P. Multi-Factoral Mechanisms of Therapeutic Effect of Perifocal Spectacles (Perifocal-M) on Progressive Myopia in Children. Oftal'mologiya, 2018, vol. 15, no. 44, pp. 433-438 (in Russian). DOI: 10.18008/1816-5095-2018-4-433-438

38. Filinova O.B. Filinova O.B. Dynamics of refraction and muscular balance in children on the background of permanent mild-myopic defocusing in binocular and monocular alternating format. Rossiiskaya pediatricheskaya oftal'mologiya, 2009, no. 1, pp. 31-33 (in Russian).

39. Proskurina O.V., Tarasova N.A., Tarutta E.P., Proskurina O.V., Tarasova N.A., Tarutta E.P. Accommodation disorders often precede the development and progression of myopia in children. Modern optometry, 2018, vol. 118, no. 8, pp. 25-29 (in Russian).

40. Vorontsova T.N. Results of medication therapy of habitually excessive tension of accommodation in children and higher-school students. Rossiiskii Oftal'mologicheskii Zhurnal, 2016, vol. 9, no. 2, pp. 18-21 (in Russian). DOI: 10.21516/2072-0076-2016-9-2-18-21

Tarutta E.P., Proskurina O.V., Tarasova N.A., Markosyan G.A. Analysis of risk factors that cause myopia in pre-school children and primary school students. Health Risk Analysis, 2019, no. 3, pp. 26-33. DOI: 10.21668/health.risk/2019.3.03.eng

Received: 12.07 .2019

Accepted: 08.08.2019

Published: 30.09 .2019 
UDC 504.5

DOI: 10.21668/health.risk/2019.3.04.eng

\title{
NANO- AND MICRO-PARTICLES CONCENTRATIONS IN WORKING AREA AIR AT GALVANIC PRODUCTION: PILOT RESEARCH
}

\author{
K.S. Golokhvast ${ }^{1}$, K.Yu. Kirichenko ${ }^{1}$, P.F. Kiku ${ }^{1}$, N.V. Efimova ${ }^{2}$, M.F. Savchenkov ${ }^{3}$, \\ I.A. Vakhnyuk ${ }^{1}$, D.Yu. Kosyanov', S.A. Medvedev ${ }^{4}$, V.P. Soparev', V.A. Drozd ${ }^{1}$ \\ ${ }^{1}$ Far Eastern Federal University, 8 Sukhanova Str., Vladivostok, 690091, Russian Federation \\ ${ }^{2}$ East-Siberian Institute of Medical and Environmental Research, 3A, 12A Mikroraion Str., Angarsk, 665827, \\ Russian Federation \\ ${ }^{3}$ Irkutsk State Medical University, 2 Krasnogo Vosstania Str., Irkutsk, 664003, Russian Federation \\ 4“Izumrud” joint-stock company, 65 Russkaya Str., Vladivostok, 690105, Russian Federation \\ 5“Dalpribor" PLC, 46/50 Borodinskaya Str., Vladivostok, 690105, Russian Federation
}

Electrochemical processes that involve making protective coats at contemporary galvanic productions are widely spread in various industries. As chemically active solutions and heavy metals are usually applied in galvanic production, it can be ranked among hazardous ones. Our research goal was to examine morphometric parameters of nano- and micro-particles that were detected in working area air at enterprises where galvanic baths and electrochemical processes were applied.

To perform a complex examination of particle-size distribution and concentration of a galvanic aerosol (GA) in working area air, we applied a combined procedure that included:

1) measuring qualitative structure of particulate matter $\left(\mathrm{mg} / \mathrm{m}^{3}\right)$ according to ISO 21501-4 in order to determine concentrations of $P M_{0.3}, P M_{0.5}, P M_{1}, P M_{3}, P M_{5}$, and $P M_{10}$ with a portable laser meter;

2) measuring mass concentrations of $P M_{10}$ according to the European Standard for determining particulate matter EN 12341:2014;

3) measuring particle-size structure of particulate matter via deposition with laser granulometry.

Quantities of particles that belonged to $P M_{0,3}$ fraction were more than 10,000 times higher in working area air inside a galvanic workshop that quantities of those belonging to $P M_{10}$ fraction. Maximum quantities of particles were detected near a nickel-plating bath. Mass concentration of $P M_{10}$ fraction amounted to $0.04 \pm 0.0001 \mathrm{mg} / \mathrm{m}^{3}$. Contents of particles with their size exceeding $700 \mu \mathrm{m}$ accounted for 30-90\% of the overall quantities of particles at most examined points; particles with their size being less than $10 \mu \mathrm{m}$ were detected only in an area where aluminum was being hardened.

Quality of working area air at galvanic production doesn't fully provide safe working conditions due to ultra-thin fractions prevalence in industrial aerosols; it can result in so called "sub-threshold effects" causing bronchopulmonary diseases.

Key words: working area, galvanic production, working conditions, air quality, industrial aerosols, nano-and microparticles.

(c) Golokhvast K.S., Kirichenko K.Yu., Kiku P.F., Efimova N.V., Savchenkov M.F., Vakhnyuk I.A., Kosyanov D.Yu., Medvedev S.A., Soparev V.P., Drozd V.A., 2019

Kirill S. Golokhvast - Doctor of Biological Sciences, Corresponding Member of the Russian Academy of Education, Professor of the Russian Academy of Sciences Professor at the Department of Life Safety in the Technosphere (e-mail: droopy@mail.ru; tel.: +7 (924) 126-13-13; ORCID: https://orcid.org/0000-0002-4873-2281).

Konstantin Yu. Kirichenko - Candidate of Biological Sciences, Researcher at the Research and Educational Center for Nanotechnologies (e-mail:Kirichenko2012@gmail.com; tel.: +7 (950) 285-76-57; ORCID: https://orcid.org/0000-0002-2715-3758).

Pavel F. Kiku - Doctor of Medical Sciences, Candidate of Technical Sciences, Professor, Head of the Department for Public Health and Preventive Medicine (e-mail: lme@list.ru; tel.: +7 (902) 555-48-91; ORCID: https://orcid.org/my-orcid/00000003-3536-8617).

Nataliya V. Efimova - Doctor of Medical Sciences, Professor, Leading Researcher at the Laboratory of Ecological and Hygienic Research (e-mail: medecolab@inbox.ru; tel.: +7 (914) 892-19-47; ORCID: http://orcid.org/0000-0001-7218-2147).

Mikhail F. Savchenkov - Doctor of Medical Sciences, Academician of the Russian Academy of Sciences, Professor, Professor of the Common Hygiene Department (e-mail: smf36@mail.ru; tel.: +7 (395) 224-38-43; ORCID: http://orcid.org/0000-0002-1246-8327).

Igor A. Vakhnuk - Postgraduate Student (e-mail: vahnuk86@mail.ru; tel.: +7 (904) 628-10-88).

Denis Y. Kosyanov - Candidate of Technical Sciences, Senior Researcher at the Laboratory of Electronic Structure and Quantum-Chemical Modeling, Department of General and Experimental Physics (e-mail: kosianov.diu@dvfu.ru; tel.: +7 (984) 156-64-80).

Stanislav A. Medvedev - Deputy Director responsible security at «Izumrud» Stock Company (e-mail: MedvedevStanislav-79@mail.ru; tel.: +7 (908) 448-85-35).

Viktor P. Soparev - Deputy Chief Technologist at «Dalpribor» Public Stock Company (e-mail: soparev@mail.ru; tel.: +7 (914) 7959870).

Vladimir A. Drozd - Radiation Safety Engineer at the Research and Educational Center for Nanotechnologies (e-mail: v_drozd@mail.ru; tel.: +7 (924) 733-12-7). 
Electrochemical processes at contemporary galvanic production are applied to make protective coats and can be met in various branches including defense and aerospace industries. Galvanic production is considered to be hazardous due to chemically active solutions and heavy metals being widely used in it. As per data provided by Rosstat a specific weight of workers employed at adverse and (or) hazardous productions grows annually $[1,2]$. As is well known, hazardous substances penetrate a worker's body not only through the respiratory tracts but also through the skin, ears, eyes, and other unprotected parts of a body [3]. Permanent exposure to negative factors existing at galvanic production causes occupational diseases, mostly in the respiratory organs and upper respiratory tracts, circulatory system, and the musculoskeletal system when working experience at such a production is from 10 to 15 years. Suspensions rich with nano- and micro-particles of heavy metals essentially occur in the air in a workshop where electrochemical processes take place; it is a significant factor for creating programs aimed at protecting workers' health. It is necessary to implement efficient prevention activities and apply protection means for workers employed at hazardous productions and workers with allied occupations if we want to reduce a number of disease cases and risks of lethal outcomes. The task can be solved only after assessing morphometric parameters of nano- and micro-particles as well as properties of particles in an industrial aerosol that occurs in a galvanic workshop.

Nano- and micro-sized suspensions in the atmosphere are detected at points that are quite remote from industrial buildings [4-6], they exert considerable influence on climate in industrial centers [7], and technogenic particles account for $45 \%$ out of overall aerosol particles [8]; nevertheless, contamination of working area air at galvanic production and adjoining territories with nano- and micro-sized suspensions hasn't been given relevant attention. If we fail to assess significance and hazards caused by nanotechnological contamination, it can cre- ate health risks for population and makes certain areas less socially and economically attractive [9]. Working conditions have a key role in protecting population health and health of welders in particular. Microclimate at a working place matters a lot as a person consumes $15 \mathrm{~kg}$ of air per day. Unsatisfactory microclimatic parameters cause occupational diseases. Particles with their size being up to $10 \mu \mathrm{m}$ are the most hazardous for human health due to their ability to cause respiratory diseases [10-12].

Previously we detected nano- and microparticles within sanitary protection zones around industrial enterprises that had galvanic workshops in their structure [5]. In particular, we'd like to mention suspended $\mathrm{Fe}$ and $\mathrm{Cr}$ particles with their diameter being equal to $10-120 \mathrm{~nm}$ and their share accounting for up to $76 \%$; however, we couldn't detect a source and a mechanism of their occurrence.

Issues related to nano-particles penetrating working area air remain outstanding. In particular, there are no criteria for assessing exposure to nanoparticles; as the chemical structure of particulate matter is usually a multi-component one, there are not enough data on potential toxicological effects produced by exposure to them and it creates significant difficulties for experts who try to substantiate hygienic standards in the sphere.

Our research goal was to perform complex analysis of nano- and micro-particles contents in working area air as a factor causing health risks for workers employed at enterprises where electroplating baths and electrochemical processes were applied.

Data and methods. We performed our research in a galvanic workshop where basic technological processes were aluminum clarification and pickling; sulfuric anodic treatment; chemical and electric aluminum degreasing; removal of sludges after pickling; non-ferrous metals pickling; chrome and nickel plating. To perform a complex examination of particle-size distribution and concentration of a galvanic aerosol (GA) in working area air, we applied a combined procedure that included: 
1) measuring quantitative structure of particulate matter $(\mathrm{mg} / \mathrm{m} 3)$ according to ISO 21501-4 in order to determine concentrations of PM0.3, PM0.5, PM1, PM3, PM5, and PM10 with a portable laser meter;

2) measuring mass concentrations of PM10 according to the European Standard for determining particulate matter EN 12341:2014;

3) measuring particle-size structure of particulate matter via deposition with laser granulometry.

1. Measuring quantitative structure of particulate matter. To quantitatively analyze and determine particles concentrations in working area air we applied a hand laser Aero Trak Handheld Particle Counter 9306 (the USA). The model 9306 conforms to all the requirements fixed in ISO 21501-4. Samples at each point were taken during 1 minute. Overall air volume that passed through the device amounted to $2.83 \mathrm{1} / \mathrm{min}$ and it was within its recommended functioning modes. Samples were taken at 1.5 meters height as it corresponded to a height at which a person usually breathes; all sampling points were located directly above an open electrolyte of an electroplating bath. Overall, we examined 11 electroplating baths in our experiment which were included into technological processes at three production lines: a line where aluminum was being prepared; a line where non-ferrous metals were being prepared; and a line where protection covers were being made. The list of sampling points and electrolytes applied in production processes is given in Table 1.

We performed 5 measurements for each type of an electroplating bath $(\mathrm{N}=60)$ in our experiment.

2. Measuring mass concentrations of particulate matter. To determine concentrations of aerosol particles $\left(\mathrm{mg} / \mathrm{m}^{3}\right)$ in working area air in a galvanic workshop, we took a series of samples near stationary electroplating baths. We chose a gravimetric procedure to measure concentrations of GA particles and used an aspiratory LVS 3.1 type sampler (Ingeniero Nobert Derenda, Germany). This sampler has a nozzle for sampling $\mathrm{PM}_{10}$ fraction and is also equipped with $47 \mathrm{~mm}$ nylonbased filters Nylon 66 Membranes without connections and their working surface diameter being $47 \mathrm{~mm}$ (SUPERLCOUSA). Flowing capacity of the filters amounted to $0.45 \mu \mathrm{m}$. Thereby, an examined range of particulate matter varied from $0.45 \mu \mathrm{m}$ to $10 \mu \mathrm{m}$. We chose $10 \mu \mathrm{m}\left(\mathrm{PM}_{10}\right)$ as an upper limit of the particles fraction as it is well in line with modern trends in control over particulate matter in the atmosphere [13-16].

Table 1

Technological processes at a galvanic workshop

\begin{tabular}{|c|l|c|c|}
\hline No. & \multicolumn{1}{|c|}{ A technological processes } & Electrolyte structure & $\begin{array}{c}\text { Production line } \\
\text { for preparing }\end{array}$ \\
\hline 1 & Background territory (offices) & - & - \\
\hline 2 & Aluminum clarification & $\mathrm{HNO}_{3}$ & Aluminum \\
\hline 3 & Aluminum pickling & $\mathrm{NaOH}$ & Aluminum \\
\hline 4 & Sulfuric anodic treatment & $\mathrm{H}_{2} \mathrm{SO}_{4}$ & Aluminum \\
\hline 5 & Aluminum degreasing & $\mathrm{Na}_{2} \mathrm{CO}_{3} ; \mathrm{Na}_{3} \mathrm{PO}_{4}$ & Aluminum \\
\hline 6 & Chemical degreasing & $\mathrm{Ja}_{0} \mathrm{Mu}_{2} 203$ & Non-ferrous metals \\
\hline 7 & Electrical degreasing & $\mathrm{Na}_{2} \mathrm{CO}_{3} ; \mathrm{Na}_{3} \mathrm{PO}_{4}$ & Non-ferrous metals \\
\hline 8 & Removal of sludges after pickling & $\mathrm{Cr}_{2} \mathrm{O}_{3} ; \mathrm{H}_{2} \mathrm{SO}_{4} ; \mathrm{NaCl}$ & Non-ferrous metals \\
\hline 9 & Non-ferrous metals pickling & $\mathrm{HNO}_{3} ; \mathrm{H}_{2} \mathrm{SO}_{4} ; \mathrm{HCl}$ & Non-ferrous metals \\
\hline 10 & Chrome plating & $\mathrm{H}_{2} \mathrm{CrO}_{4} ; \mathrm{H}_{2} \mathrm{SO}_{4}$ & Non-ferrous metals \\
\hline 11 & Nickel plating & $\mathrm{NiSO}_{4} ; \mathrm{MgSO}_{4} ; \mathrm{Na}_{2} \mathrm{SO}_{4} ; \mathrm{NaCl} ; \mathrm{H}_{3} \mathrm{BO}_{3}$ & Non-ferrous metals \\
\hline 12 & Chemical nickel plating & $\mathrm{NiSO}_{4} ; \mathrm{MgSO}_{4} ; \mathrm{Na}_{2} \mathrm{SO}_{4} ; \mathrm{NaCl} ; \mathrm{H}_{3} \mathrm{BO}_{3}$ & Non-ferrous metals \\
\hline
\end{tabular}


Table 2

Particle size distribution for an industrial aerosol in a galvanic workshop, units $/ 100 \mathrm{~cm}^{3}$

\begin{tabular}{|c|l|c|c|c|c|c|c|}
\hline № & \multicolumn{1}{|c|}{ Sampling point } & $\mathrm{PM}_{0,3}$ & $\mathrm{PM}_{0,5}$ & $\mathrm{PM}_{1}$ & $\mathrm{PM}_{3}$ & $\mathrm{PM}_{5}$ & $\mathrm{PM}_{10}$ \\
\hline 0 & Background territories (offices) & 159,643 & 29,317 & 2,318 & 196 & 74 & 10 \\
\hline 1 & Aluminum clarification & $19,247,204$ & $3,126,713$ & 269,112 & 42,071 & 18,171 & 2,282 \\
\hline 2 & Aluminum pickling & $18,774,926$ & $2,858,021$ & 234,399 & 34,086 & 13,895 & 1,711 \\
\hline 3 & Sulfuric anodic treatment & $18,758,289$ & $3,134,410$ & 286,763 & 48,169 & 20,977 & 2,938 \\
\hline 4 & Aluminum degreasing & $28,703,393$ & $6,005,978$ & 338,080 & 35,892 & 14,768 & 1,766 \\
\hline 5 & Chemical degreasing & $16,610,093$ & $4,995,215$ & $1,119,675$ & 459,242 & 273,288 & 44,287 \\
\hline 6 & Electrical degreasing & $23,821,193$ & $4,836,159$ & 290,667 & 36,512 & 15,388 & 2,186 \\
\hline 7 & Removal of sludges after pickling & $19,961,226$ & $3,427,211$ & 250,587 & 33,378 & 13,710 & 1,666 \\
\hline 8 & Non-ferrous metals pickling & $20,526,593$ & $3,053,826$ & 237,555 & 30,997 & 12,420 & 1,600 \\
\hline 9 & Chrome plating & $10,932,963$ & $1,671,387$ & 181,983 & 24,534 & 9,946 & 1,150 \\
\hline 10 & Nickel plating & $20,245,996$ & $3,689,208$ & 337,626 & 33,953 & 12,332 & 1,180 \\
\hline 11 & Chemical nickel plating & $31,279,133$ & $10,266,759$ & 715,403 & 22,772 & 6,628 & 406 \\
\hline
\end{tabular}

Prior to sampling the filters had been dried in TC-1/20 thermostat (Russia) for 24 hours at $40{ }^{\circ} \mathrm{C}$; after that each filter was weighted 5 times with an electronic balance Sartorius (Germany) and a mean value for a weight was determined. Readings were taken at 5 points in a galvanic workshop; those points were located at a distance from 1 to 5 meters away from stationary nickel plating baths as such baths were sources of the most toxic particles. The nozzle was fixed at 1.5 meters height as it corresponded to a height at which a person usually breathes. We obtained 10 sets of data for each type of an electroplating bath $(\mathrm{N}=50)$ in our experiment.

3. Measuring particle-size structure of particulate matter via deposition. To perform particle-size analysis for particles contained in working area air, we took samples via the following procedure: we placed sterile plastic containers on the workshop floor where workers performed their tasks in a workshop; a volume of each container amounted to 2.7 liters and they were all filled with distilled water (this water treatment procedure completely removes any particulate matter from water) obtained with DE-4-02-EMO water distillation device ("Electromedoborudovanye" LLC, Saint Petersburg, Russia). Particles settled into open containers. The procedure was chosen due to a possibility to collect the whole range of nano- and micro-particles as it is not the case with any other alternative method (any applied filter has a minimal size equal to 430 $\mathrm{nm}$ and it means that smaller particles pass through it freely). Prior to the experiment all the containers had been thoroughly washed, firstly with running water, and then twice with distilled water; after it the containers were filled with $600-800 \mathrm{ml}$ of distilled water which amounted to $1 / 3$ of their overall volume. We wrote down a denomination of an electroplating bath for each sample as well as a date and time at which it was taken.

Our experiment lasted for 8 hours as it was equal to working shift duration in the chosen workshop. The containers were placed close to operating stationary electroplating baths and were open at 8 a.m. just as a working shift started. As the shift ended at 17 p.m., the containers were tightly closed, marked and transported to a laboratory for further research.

Results were statistically processed with "Statistica 10.0" software package; we assessed statistical significance of parameters and discrepancies between examined samplings as per Student's t-test taking into account a type of values distribution.

Results and discussion. Having examined particle-size distribution, we detected that the smallest particles prevailed absolutely (Table 2).

A quantity of $\mathrm{PM}_{0,3}$ (particles smaller than $0.3 \mu \mathrm{m}$ ) was more than 10,000 times 
higher than a quantity of $\mathrm{PM}_{10}$. Maximum particles concentrations were detected near a nickel plating bath, a stationary one with treatment temperature being $15-25{ }^{\circ} \mathrm{C}$. The bath was applied for electrochemical treatment of metals and was equipped with ventilation systems; it was heated by a direct current source. As samples were taken directly above contents of stationary electroplating baths, the results we obtained prove that primary particles in industrial aerosols which occur during electrochemical processes tend to have very small sizes. Basically, primary particles tend to be smaller than $0.3 \mu \mathrm{m}$.

We measured concentrations of particulate matter with particles sizes being less than $10 \mu \mathrm{m}$ at a distance $1-3$ meters away from stationary baths for chemical nickel plating, nickel plating, and an aluminum preparation line; our measuring revealed that particles concentrations were within $0.0417 \pm 0.0001$ $0.0438 \pm 0.0002 \mathrm{mg} / \mathrm{m}^{3}$ range and didn't change significantly at an examined distance.

At present, both in the RF and worldwide, there are no standards for assessing nano- and micro-particles contents in working area air at galvanic production. But still, some research works $[1,4,5$, and 17] indicate that particles with different sizes occur in the air inside galvanic workshops. Our particle size analysis revealed that particles with their size being less than $10 \mu \mathrm{m}$ prevailed in working area air; among them the most frequent particles were ultrathin ones or $\mathrm{PM}_{0,3}$. The smallest particles of heavy metals in industrial aerosols are able to penetrate deep into the respiratory organs and spread further all over a body [11] causing chronic diseases in the respiratory tracts and overall decrease in working capacity.

As there are no data on elemental structure of GA mixture in electroplating production, it is impossible to hygienically assess the results we have obtained in our experiments. We should note that standards for permissible nano-particles contents differ greatly for their types; thus, for example, the standard for single-shell carbon nanotubes is
$0.007 \mathrm{mg} / \mathrm{m}^{3}$, and that for titanium oxide nanoparticles is $0,3 \mathrm{mg} / \mathrm{m}^{3}$. Given that, it is necessary to perform further research and standardize contents of nanoparticles with various chemical structures.

The results of particle size analysis performed on particulate matter via deposition indicate that there are two types of suspension occurring at electroplating production. The Figures show typical graphs of particles distribution as per their sizes: first, prevailing particles with their size being less than $10 \mu \mathrm{m}$ (Figure 1) and, secondly, with prevailing particles sized more than $700 \mu \mathrm{m}$ (Figure 2). The first variant occurs only at an aluminum hardening line (2 samples out of 12). We should note that the greatest specific weight of particles smaller than $10 \mu \mathrm{m}(88.2 \%)$ was detected in a sample taken at an aluminum hardening line near a stationary bath for aluminum degreasing. Samples taken at other points contained from $30 \%$ to $90 \%$ particles which were bigger than $700 \mu \mathrm{m}$. We should also note that there were practically no particles with their sizes ranging from $50 \mu \mathrm{m}$ to $400 \mu \mathrm{m}$ in the examined samples.

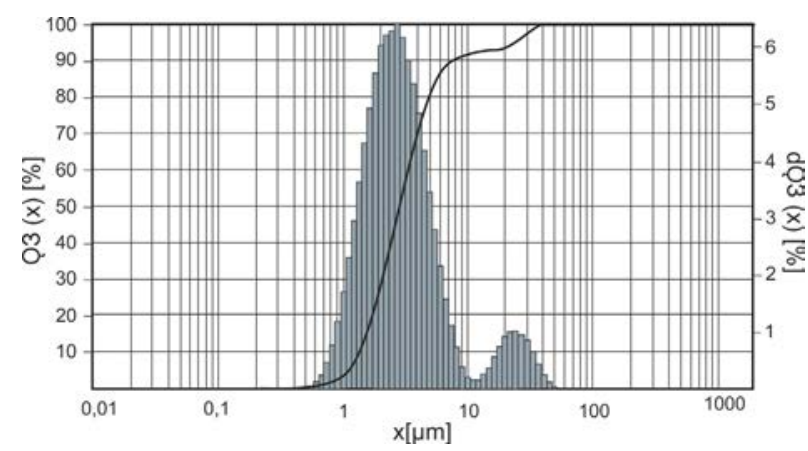

Figure 1. Particle size distribution in Sample No. 4 (aluminum degreasing)

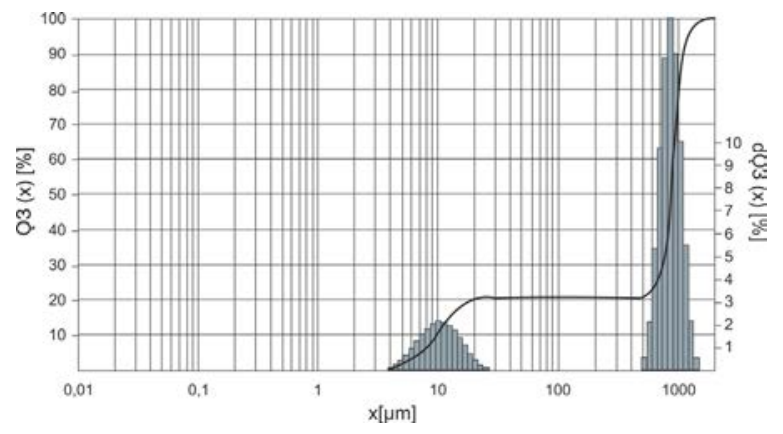

Figure 2. Particle size distribution in Sample No. 12 
Data obtained via analysis of particle size distribution indicate that there is quantitative prevalence of large particles. The detected discrepancy between results of two different procedures which we applied is due to both different sampling techniques and particles behavior in the air. When samples are taken directly above electroplating baths, $\mathrm{PM}_{0,3}$ are detected most frequently. Primary particles with their size being smaller than $0.3 \mu \mathrm{m}$ occur above stationary baths during a working shift, turn into suspended state, stick together, and form large aggregates and clusters; as such aggregates and clusters grows bigger than $700 \mu \mathrm{m}$, they settle. We should note that measuring itself was limited by flow capacity of chosen filters which was $0.45 \mu \mathrm{m}$; that is, particulate matter that were smaller flew through the aspirator freely and didn't settle on the filter. Therefore, we should assume that if filters with lower flow capacity are applied in an experiment, obtained values can be higher than ours. However, it is a common thinking that ultrathin particles, despite their significant quantity, make a very small contribution into the overall weight of particulate matter in the air [18].

Our pilot research proves there is a high quantitative concentration of particulate matter in a galvanic workshop with predominant particles sized up to $0.3 \mu \mathrm{m}$; such particles are the most hazardous for human health as they can cause bronchopulmonary diseases, including industrially induced and occupational pathologies. Workers should be well aware of the risks as it will allow better control over exposure to such particles.
But at the same time, the obtained results have some uncertainties. As PM properties depend not only on sizes but also on chemical structure, we can't compare obtained concentrations with any standard at the moment. There should be further research; in particular, it is necessary to determine chemical and qualitative structure of GA. When the task is solved, it will allow performing a toxicological experiment and developing hygienic standards for nano- and micro-particles contents in working area air [19-21].

Conclusion. We examined stationary nickel plating and aluminum preparation lines and showed that high $\mathrm{PM}_{10}$ mass quantity in working are air was caused by occurrence of large aggregates made of primary finest particles suspended in working are air in a galvanic workshop. Absolute prevalence of finest $\mathrm{PM}_{0,3}$ (data obtained with a portable particle counter) and a consequent decrease in their quantity (as per measuring particles size distribution) was caused by aggregation of particles in the air during a working shift and a prevailing gas component in an industrial aerosol. The results of our research, together with those obtained in further one, can be applied for consequent correct assessment of exposure to particulate matter distributed in working area air. The results can also be applied in epidemiologic research on workers' health.

Funding. The RF President Grant for young scientists MK-2461.2019.5.

Conflict of interests. The authors declare there is no any conflict of interests.

\section{References}

1. Trushkova E.A., Gorbatkova A.V., Vel'chenko A.A. Gigienicheskaya otsenka uslovii truda gal'vanikov [Hygienic assessment of working conditions for galvanizers]. Aktual'nye napravleniya innovatsionnogo razvitiya zhivotnovodstva i sovremennye tekhnologii proizvodstva produktov pitaniya: sbornik materialov mezhdunarodnoi nauchno-prakticheskoi konferentsii. Moscow, 2016, pp. 306-309 (in Russian).

2. Omelchenko E.V., Trushkova E.A., Sidelnikov M.V., Pushenko S.L., Staseva E.V. Algorithm Research Exposure Dust Emissions Enterprises of Building Production on the Environment. IOP Conference Series: Earth and Environmental Science, 2017, vol. 50, no. 1, 6 p. DOI: 10.1088/1755$1315 / 50 / 1 / 012018$

3. Halliday-Bell J., Palmer K., Crane G. Health and safety behaviour and compliance in electroplating workshops. Occup. Med. (Lond), 1997, vol. 47, no. 4, pp. 237-240. DOI: 10.1093/occmed/47.4.237 
4. Kiryushina N.Yu. Osobennosti ochistki stochnykh vod gal'vanicheskikh proizvodstv of ionov tyazhelykh metallov shlakom elektrostaleplavil'nogo proizvodstva [Peculiarities related to removing heavy metals ions from sewage of galvanic productions with slag from electrical steel-smelting production]. Vodoochistka, 2013, no. 6, pp. 44-58 (in Russian).

5. Golokhvast K.S., Shvedova A.A. Galvanic Manufacturing in the cities of Russia: Potential source of ambient nanoparticles. PLOS One, 2014, vol. 9, no. 10, pp. e110573. DOI: 10.1371/journal.pone.0110573

6. Guo P.R., Lei Y.Q., Zhou Q.L., Wang C., Pan J.C. Distribution Characteristics of Heavy Metals in Environmental Samples Around Electroplating Factories and the Health Risk Assessment. Huan Jing Ke Xue, 2015, vol. 36, no. 9, pp. 3447-3456.

7. Belan B.D., Simonenkov D.V., Tolmachev G.N. Chemical composition of industrial aerosol in some regions. Chemical Engineering Transactions, 2010, vol. 22, pp. 197-202. DOI: 10.3303/CET1022032

8. Drozd V.A., Kholodov A.S., Agoshkov A.I., Petukhov V.I., Blinovskaya Ya.Yu., Lushpey V.P., Vasyanovich Yu.A., Solomennik S.F. [et al.]. Potentional toxic risk from the nano- and microparticles in the atmospheric suspension of Russky Island (Vladivostok). Der Pharma Chemica, 2016, vol. 8, no. 11, pp. 231-235.

9. Baracchini E., Bianco C., Crosera M., Filon F.L., Belluso E., Capella S., Maina G., Adami G. Nano- and Submicron Particles Emission during Gas Tungsten Arc Welding (GTAW) of Steel: Differences between Automatic and Manual Process. Aerosol and Air Quality Research, 2018, vol. 18, no. 3, pp. 579-589. DOI: 10.4209/aaqr.2017.07.0226

10. Penttinen P., Timonen K.L., Tiittanen P., Mirme A., Ruuskanen J.,Pekkanen J. Ultrafine particles in urban air and respiratory health among adult asthmatics. European Respiratory Journal, 2001, vol. 17, no. 3, pp. 428-435. DOI: 10.1183/09031936.01.17304280

11. Simonova I.N., Antonyuk M.V., Vitkina T.I. The influence of nanoparticles from the air on the state of bronchopulmonary system. Byulleten' fiziologii i patologii dykhaniya, 2013, no. 49, pp. 115-120 (in Russian).

12. Zheng W., Antonini J.M., Lin Y.C., Roberts J.R., Kashon M.L., Castranova V., Kan H. Cardiovascular effects in rats after intratracheal instillation of metal welding particles. Inhal Toxicol, 2015, vol. 27, no. 1, pp. 45-53. DOI: 10.3109/08958378.2014.982309

13. Achilleos S., Evans J.S., Yiallouros P.K., Kleanthous S., Schwartz J., Koutrakis P. PM10 concentration levels at an urban and background site in Cyprus: the impact of urban sources and dust storms. J. Air Waste Manag. Assoc, 2014, vol. 64, no. 12, pp. 1352-1360. DOI: 10.1080/10962247.2014.923061

14. Zhang X.-X., Chen X., Wang Z.-F., Guo Y.-H., Li J., Chen H.-S., Yang W.-Y., Sharratt B., Liu L.-Y. Dust deposition and ambient PM10 concentration in Northwest China: spatial and temporal variability. Atmospheric Chemistry and Physics, 2017, vol. 17, no. 3, pp. 1699-1711. DOI: 10.5194/acp-17-1699-2017

15. Prosviryakova I.A., Shevchuk L.M. Hygienic assessment of pm10 and pm2.5 contents in the atmosphere and population health risk in zones infleunced by emissions from stationary sources located at industrial enterprises. Health Risk Analysis, 2018, no. 2, pp. 14-22. DOI: 10.21668/health.risk/2018.2.02.eng (in Russian).

16. Osnovy otsenki riska dlya zdorov'ya naseleniya pri vozdeistvii khimicheskikh veshchestv, zagryaznyayushchikh okruzhayushchuyu sredu [Guidelines on assessment of population health risk under exposure to chemicals which pollute environment]. In: Yu.A. Rakhmanin, G.G. Onishchenko eds. Moscow, Nauchno-issledovatel'skii institute ekologii cheloveka i gigieny okruzhayushchei sredy imeni A.N. Sysina Publ., 2002, 408 p. (in Russian).

17. EH40/2005 Workplace exposure limits. Health and Safety Executive, 2018, vol.3.Available at: http://www.hse.gov.uk/pUbns/priced/eh40.pdf (10.03.2019).

18. Oberdörster G. Pulmonary effects of inhaled ultrafine particles. International Archives of Occupational and Environmental Health, 2001, vol. 74, no. 1, pp. 1-8. 
19. Beattie H., Keen Ch., Coldwell M., Tan E., Morton J., McAlinden J., Smith P. The use of bio-monitoring to assess exposure in the electroplating industry. J. Expo. Sci. Environ. Epidemiol., 2017, vol. 27, no. 1, pp. 47-55. DOI: 10.1038/jes.2015.67

20. Pan C.H., Jeng H.A., Lai C.H. Biomarkers of oxidative stress in electroplating workers exposed to hexavalent chromium. J. Expo. Sci. Environ. Epidemiol., 2018, vol. 28, no. 1, pp. 76-83. DOI: $10.1038 /$ jes.2016.85

21. Guo S., Hu M., Zamora M.L., Peng J., Shang D., Zheng J., Du Zh., Wu Zh. [et al.] Elucidating severe urban haze formation in China. Proceedings of the National Academy of Sciences of the United States of America, 2014, vol. 111, no. 49, pp. 17373-17378. DOI: 10.1073/pnas.1419604111

Golokhvast K.S., Kirichenko K.Yu., Kiku P.F., Efimova N.V., Savchenkov M.F., Vakhnyuk I.A., Kosyanov D.Yu., Medvedev S.A., Soparev V.P., Drozd V.A. Nano- and micro-particles concentrations in working area air at galvanic production: pilot research. Health Risk Analysis, 2019, no. 3, pp. 34-41. DOI: 10.21668/health.risk/2019.3.04.eng

Received: 01.04.2019

Accepted: 08.08.2019

Published: 30.09.2019 
UDC 613.26; 614.31

DOI: $10.21668 /$ health.risk/2019.3.05.eng

\title{
ANALYZING HEALTH RISKS FOR EMPLOYABLE POPULATION CAUSED BY FOOD PRODUCTS CONTAMINATION (EXPERIENCE GAINED IN SAMARA REGION)
}

\author{
D.O. Gorbachev, O.V. Sazonova, L.M. Borodina, M.Y. Gavryushin
}

Samara State Medical University, 89 Chapayevskaya Str., Samara, 443099, Russian Federation

Nowadays it is essential to provide safe nutrition for population via activities aimed at reducing risks related to adverse effects produced by contaminants on people's health; such activities include those accomplished within the state sanitary-epidemiologic surveillance. As per data provided by Samara Regional Center for Hygiene and Epidemiology, 71,204 food products samples were analyzed; analysis focused on contents of heavy metals (cadmium, mercury, lead, and arsenic), pesticides (hexachlorocyclohexane or HCCH, Dichlorodiphenyltrichloroethane or DDT,) nitrates, nitrites, aflatoxin B1, and benzpyrene. Next, exposure was assessed and risks of carcinogenic and non-carcinogenic effects were calculated. Analysis of an aggregated hazard index created as per median values of contaminants contents revealed that arsenic made a substantial contribution into risks which was equal to $48 \%$. The second rank place belonged to cadmium that accounted for $14 \%$; the third one was occupied with nitrates, $12 \%$. The following food products groups contributed into the aggregated hazard index: melons and vegetables (23\%), bread and grocery (22\%), milk and milk products (12\%), meat and meat products (11\%), fruit and berries (9\%). It was shown that simultaneous introduction of the examined contaminants taking into account the highest non-carcinogenic risks exerted the most adverse impacts on the hormonal system due to combined exposure to cadmium, mercury, lead, arsenic, and DDT. We assessed carcinogenic risks caused by combined introduction of the contaminants taking into account their median concentrations and revealed that the risks were within the third range. We designed evolution models for carcinogenic risks basing on calculated consumption of various food products both as per median concentrations and 90\%-percentile; it allowed us to assess these risks as being "negligible". It was shown that the state sanitary-epidemiologic surveillance in Samara region accomplished all the necessary activities as regards monitoring over quality and safety of food products, both domestic and imported.

Key words: contamination, heavy metals, pesticides, food products, non-carcinogenic risks, carcinogenic risks, evolution models, food security.

Nutrition plays a key role in protecting and preserving people's health $[1,2]$. Components in nutrition provide a body with all the necessary macro- and microelements; food is a source of energy; nutrients that are contained in a ration exert their influence on body growth and development and protect it from adverse effects produced by environmental factors [3-7]. But still, alien components that occur in food raw materials and food products can exert negative impacts on human health via reducing adaptation potential of a body; in its turn, it can result in carcinogenic and non-carcinogenic effects [8-13]. Food products contamination primarily occurs due to anthropogenic reasons as it is closely connected with economic activities performed by people [14-19]. At present there are certain activities that are being accomplished within implementation of such documents as

(C) Gorbachev D.O., Sazonova O.V., Borodina L.M., Gavryushin M.Y., 2019

Dmitry O. Gorbachev - Candidate of Medical Sciences, Associate professor at the Nutrition Hygiene Department with a course in hygiene for children and teenagers (e-mail: Dmitriy-426@rambler.ru; tel.: +7(846) 332-70-89; ORCID: https:// orcid.org/0000-0002-8044-9806).

Olga V. Sazonova - Doctor of Medical Sciences, head of the Nutrition Hygiene Department with a course in hygiene for children and teenagers (e-mail: ov_2004@mail.ru; tel.: +7(846) 332-70-89; ORCID: https://orcid.org/0000-0002-4130-492X).

Lyubov M. Borodina - Candidate of Medical Sciences, Associate professor at the Nutrition Hygiene Department with a course in hygiene for children and teenagers, Leading Researcher (e-mail: smlm@mail.ru; tel.: +7(846) 332-70-89; ORCID: https://orcid.org/0000-0002-5165-8254).

Mikhail Yu. Gavryushin - Candidate of Medical Sciences, Senior Lecturer at the Nutrition Hygiene Department with a course in hygiene for children and teenagers, Leading Researcher (e-mail: muiltex555@yandex.ru; tel.: +7(846) 332-70-89; ORCID: https://orcid.org/0000-0002-0897-7700). 
"The Doctrine of Food Security in the Russian Federation"1, "The Basics of the state policy as regards providing healthy nutrition to population up to 2020 "2, "The Strategy for improving quality of food products in the Russian Federation up to $2030{ }^{3}$; ; these activities are aimed at reducing risks of adverse effects produced by contaminants in food on human health and they are accomplished, among other things, via the state system for sanitary-epidemiologic surveillance [20]. Monitoring over quality and safety of food products, both produced domestically and imported from abroad, is an efficient tool that allows achieving the above-mentioned goals. This monitoring is performed within the social-hygienic monitoring system due to the Federal Information Fund (FIF) functioning. All the data that are accumulated due to monitoring give grounds for taking administrative measures that can include products being withdrawn from distribution, ban on food products imports, or imposing limitations on their application. Besides, monitoring activities also involve assessing health risks caused by contamination of food products and food raw materials. Monitoring results are applied to make managerial decisions and to provide customers with information on food products $[21,22]$. Nowadays experts in Russia apply methodic approaches based on unified risk assessment criteria and consisting of several stages; these stages are hazard identification, assessment of "exposure - response" relationship, assessment of exposure, and risk characteristics. Mathematical modeling of risks evolution over time is a promising trend in risk assessment. This approach allows the most precise estimation of probable impacts exerted by alimentary contaminants on various organs and systems in living objects [23].

So, we should consider influence exerted by nutrition on a human body not only in terms of its ability to satisfy its physiological needs in nutrients and energy but also in terms of potential risks caused by anthropogenic contaminants contained in food raw materials and products. We should note that adverse effects produced by the said contamination are aggravated when people work under hazardous conditions and/or when they don't adhere to the principles of rational and healthy nutrition. All the above-mentioned issues determined our research goal and methodology; our research object was Samara region, an average statistical one in the RF.

Our research goal was to assess health risks for employable population in Samara region caused by food products contamination.

Data and methods. We assessed admixtures in food products as per data collected over 11 years and provided by the laboratory of the Samara Regional Center for Hygiene and Epidemiology. We analyzed 71,204 samples during our research and made a data array that was applied to create a database entitled "the Database on food products contamination" that allowed collecting, storage, and dynamic processing of data on food products contamination. We applied median and 90-th percentile of contaminant contents in food products in order to calculate exposure. We examined food products that were both produced locally and brought to the region from other territories, including imports. We determined contents of heavy metals (cadmium,

\footnotetext{
${ }^{1}$ On Approval of the Doctrine of Food Security in the Russian Federation: The RF President Order dated January 30, 2010 No. 120. Rossiyskaya gazeta, 2010, the Federal issue No. 21 (5100). Available at: https://rg.ru/2010/02/03/proddok.html (date of visit May 10, 2019).

${ }^{2}$ The Basics of the state policy as regard providing healthy nutrition to population up to 2020: The RF Government Order dated October 25, 2010 No. 1873-r. KonsultantPlus. Available at: http://www.consultant.ru/document/cons_doc_LAW_106196/abb337778165250dae206cadc6dc91e21308f022/(date of visit May 10, 2019).

${ }^{3}$ On Approval of the Strategy for improving quality of food products in the Russian Federation up to 2030: The RF Government Order dated June 29, 2016 No.1364-r. The official web-site of the RF Government. Available at: http://government.ru/docs/23604/ (date of visit May 10, 2019).

${ }^{4}$ Baturin A.K., Martinchik A.N., Gorbachyov D.O., Sazonova O.V., Mikhailov N.A. The Certificate of the state registration of a PC program 2018616624 RF. "Nutri-prof" software package for assessing actual nutrition. The Federal Research Center for Nutrition and Biotechnology, Samara State Medical University of the RF Public Healthcare Ministry. No. 2018613172. Bulletin No. 6, 1 p.
} 
mercury, lead, and arsenic), pesticides (hexachlorocyclohexane $(\mathrm{HCCH}), \mathrm{DDT})$, nitrates, nitrites, aflatoxin $\mathrm{B} 1$, and benzpyrene in all examined food products. Exposure was assessed and risks of carcinogenic and noncarcinogenic effects were calculated automatically according to "the Guidelines on assessment of population health risks under exposure to chemicals that pollute the environment", Total hazard index (HI) was calculated for a single-time introduction and long-term exposure to several contaminants as per median values of exposure and its 90-th percentile.

We assessed carcinogenic risks basing on calculated values of exposure to contaminants as per median and the 90-th percentile taking into account factors of carcinogenic potential (slope factors). In addition we calculated population carcinogenic risk (per 10,000 people).

Workers employed at industrial enterprises, educational establishments, medical organizations, agricultural companies, and office personnel took part in our research; they all permanently lived in Samara region. Our sampling included 1,736 people. Unlike a methodology for exposure calculation based on the data on average annual food products consumption per capita (applied by the Federal Statistics Service), we applied data on individual average annual food products consumption obtained via assessing actual nutrition consumed by employable population. The assessment was based on a methodology that involved 24-hour reproduction of a ration with "Nutri-prof" software package.

To assess health risks caused by food products contamination, we additionally used calculation forms of evolution models. They were based on recurrence relations for different responses to exposure that became apparent via health disorders [24].

Results and discussion. We analyzed distribution of the examined samples and revealed that fruit and vegetables accounted for the greatest share of samples $(28 \%)$; all the other food product groups on average accounted for $12-14 \%$. The greatest number of samples was local food products, and only $18.2 \%$ were products brought to the region from other territories.

We analyzed contaminants contents in food products and revealed the greatest cadmium concentrations as per median values in milk and milk products, sugar and confectionary (mostly in cacao beans), fish and fish products, bread and groceries; the smallest cadmium concentrations were detected in eggs and potatoes (the median value spread was $0.04-0.0125 \mathrm{mg} / \mathrm{kg}$ ). The greatest quantities of mercury were detected in fish and fish products; as for the other food products, they had mercury in almost identical concentrations, the median value spread being $0.0161-0.0013 \mathrm{mg} / \mathrm{kg}$.

Analysis of lead contents in food products revealed its maximum median concentrations in fish and fish products, potatoes, bread and groceries, the median value spread being $0.076-0.02 \mathrm{mg} / \mathrm{kg}$.

We ranked food products as per median concentrations of arsenic and revealed that fish and fish products, potatoes, bread and groceries contained this metal in the greatest quantities, the value spread being $0.0691-0.0122 \mathrm{mg} / \mathrm{kg}$.

The maximum $\mathrm{HCCH}$ median concentrations were detected in eggs, vegetable oil, and other fats. The lowest concentrations were detected in vegetable products such as vegetables, fruits, and potatoes, the value spread being $0.0163-0.0032 \mathrm{mg} / \mathrm{kg}$. DDT was detected in the greatest concentrations in meat and meat products, vegetable oil, and other fats, the value spread being $0.0143-0.0044 \mathrm{mg} / \mathrm{kg}$.

The greatest median nitrates concentrations were detected in potatoes, vegetables, and melons, the value spread being 56.48-87.3 $\mathrm{mg} / \mathrm{kg}$. Median nitrates concentration in berries amounted to $26.456 \mathrm{mg} / \mathrm{kg}$. The maximum nitrates concentration was detected in meat

\footnotetext{
${ }^{5}$ G 2.1.10.1920-04. The Guidelines on assessment of population health risks under exposure to chemicals that pollute the environment. Moscow, The Federal Center for State Sanitary-Epidemiologic Surveillance of the RF Public Healthcare Ministry Publ., 2004, 143 p.
} 
and meat products (sausages, boiled sausage, and smoked sausage).

We ranked food products as per median concentrations of aflatoxin $\mathrm{B} 1$ and revealed its greatest concentrations in vegetable oil and other fats, bread and groceries, sugar and confectionary, the value spread being $0.0002-0.00019 \mathrm{mg} / \mathrm{kg}$. The greatest benzpyrene concentrations as per median values were detected in fish and fish products, meat and meat products, the value spread being $0.0002-0.0004 \mathrm{mg} / \mathrm{kg}$.

The data we obtained on admixtures contents in food products together with data on individual average annual consumption obtained via assessing actual nutrition consumed by employable population, allowed us to calculate exposure and hazard quotients for noncarcinogenic effects produced by exposure to anthropogenic contaminants (Table 1).

\section{Table 1}

Exposure (EXP, $\mathrm{mg} / \mathrm{kg} /$ day) and hazard quotients (HQ) for non-carcinogenic effects produced by exposure to anthropogenic contaminants as per median and 90-the percentile

\begin{tabular}{|l|c|c|c|c|}
\hline $\begin{array}{c}\text { Contami- } \\
\text { nants }\end{array}$ & $\mathrm{EXP}_{\text {ме }}$ & $\mathrm{EXP}_{90}$ & $\mathrm{HQ}_{\text {ме }}$ & $\mathrm{HQ}_{90}$ \\
\hline Cadmium & 0.00013 & 0.00028 & 0.27 & 0.56 \\
\hline Mercury & $4.28097 \mathrm{E}-05$ & 0.00014 & 0.14 & 0.48 \\
\hline Lead & 0.00061 & 0.0017 & 0.17 & 0.50 \\
\hline Arsenic & 0.00027 & 0.00057 & 0.89 & 1.9 \\
\hline HCCH & $7.55513 \mathrm{E}-05$ & 0.000601 & 0.0075 & 0.0604 \\
\hline DDT & $8.79349 \mathrm{E}-05$ & 0.00022 & 0.175 & 0.45 \\
\hline Nitrates & 0.3462 & 1.0085 & 0.22 & 0.63 \\
\hline Nitrites & $2.40469 \mathrm{E}-05$ & 0.028 & 0.00024 & 0.28 \\
\hline $\begin{array}{l}\text { Aflatoxin } \\
\text { B1 }\end{array}$ & $9.23169 \mathrm{E}-07$ & $1.08517 \mathrm{E}-05$ & 0.0185 & 0.217 \\
\hline $\begin{array}{l}\text { Ben- } \\
\text { zpyrene }\end{array}$ & $2.03296 \mathrm{E}-07$ & $1.50772 \mathrm{E}-06$ & 0.00041 & 0.003 \\
\hline
\end{tabular}

Total hazard index as per median amounted to 1.9; as per 90-th percentile, to 5 . We detected substantial contributions made by the following contaminants into the total hazard index calculated as per median contaminants concentrations: arsenic, $48 \%$; the second rank place belonged to cadmium, $14 \%$; the third place was taken by nitrates, $12 \%$. Contri- butions made by contaminants into total hazard index as per 90-th percentile were distributed as follows: the first rank place belonged to arsenic (37\%); the second one, nitrates $(13 \%)$; the third one, cadmium $(11 \%)$. Basic product groups that made the most substantial contribution into the total hazard index were vegetables and melons (23\%), bread and groceries $(22 \%)$, milk and milk products $(12 \%)$, meat and meat products $(11 \%)$, fruit and berries $(9 \%)$.

We considered a scenario when all the examined contaminants were introduced simultaneously taking into account maximum non-carcinogenic risks and revealed the highest risks of probable adverse effects for the hormonal system due to combined exposure to cadmium, mercury, lead, arsenic, and DDT (Table 2).

Table 2

Total hazard index (HI) under combined effects produced by contaminants on critical organs and systems (90-th percentile)

\begin{tabular}{|l|c|}
\hline Critical organs and systems/contaminants & HI \\
\hline $\begin{array}{l}\text { Hormonal system (cadmium, mercury, lead, } \\
\text { arsenic, and DDT) }\end{array}$ & 3.6 \\
\hline Nervous system (mercury, lead, and arsenic) & 2.7 \\
\hline Immune system (mercury and arsenic) & 2.2 \\
\hline Cardiovascular system (arsenic and nitrates) & 2.4 \\
\hline Reproductive system (mercury and lead) & 0.9 \\
\hline Skin (arsenic) & 1.8 \\
\hline Kidneys (cadmium and mercury) & 0.9 \\
\hline Gastrointestinal tract (arsenic) & 1.8 \\
\hline Blood (lead, nitrates, and nitrites) & 0.9 \\
\hline Liver (DDT) & 0.4 \\
\hline
\end{tabular}

We detected that maximum individual and population carcinogenic risks were caused by exposure to arsenic taking into account median values of exposure to contaminants; if we took exposure values as per 90-th percentile, the maximum risks were caused by exposure to $\mathrm{HCCH}$ and arsenic (Table 3).

We assessed carcinogenic risks caused by combined exposure to contaminants taking into account their median concentrations and revealed that the risk level corresponded to the third range (individual lifelong risk was within a range from $1 \mathrm{E}-04$ to $1 \mathrm{E}-03$ ) which was ac- 
ceptable for occupational groups and unacceptable for population in general. We also assessed carcinogenic risks under combined lifelong exposure to contaminants as per 90-th percentile and revealed that the risk was within the fourth range and was characterized as unacceptable (individual lifelong risk was equal to or higher than 0.001 ); it called for immediate organizational activities aimed at reducing the said risk.

Table 3

Individual and population carcinogenic risks caused by exposure to contaminants

(as per median and 90-th percentile)

\begin{tabular}{|l|c|c|c|c|}
\hline Contaminants & $\mathrm{CR}_{\mathrm{Me}}$ & $\mathrm{PCR}_{\mathrm{Me}}$ & $\mathrm{CR}_{90}$ & $\mathrm{PCR}_{90}$ \\
\hline Cadmium & $5.15 \mathrm{E}-05$ & 0.5 & 0.000107 & 1.07 \\
\hline Lead & $2.8 \mathrm{E}-05$ & 0.28 & $7.9 \mathrm{E}-05$ & 0.79 \\
\hline Arsenic & 0.00040 & 4 & 0.00086 & 8.6 \\
\hline DDT & $2.9 \mathrm{E}-05$ & 0.29 & $7.6 \mathrm{E}-05$ & 0.76 \\
\hline Benzpyrene & $1.4 \mathrm{E}-06$ & 0.01 & $1.1 \mathrm{E}-05$ & 0.11 \\
\hline HCCH & 0.000135 & 1.35 & 0.00108 & 10.8 \\
\hline$\sum$ & $6.45 \mathrm{E}-04$ & 6.43 & 0.00221 & 22.13 \\
\hline
\end{tabular}

We built evolution models for combined introduction of contaminants taking into account individual average annual consumption; it allowed us to determine groups of products that caused the highest risks as well as organs and systems that were the most susceptible to adverse effects produced by contaminants. Our calculations revealed that the earliest transition of a risk from being "negligible" to being "moderate" happened at an age equal to 58.2 years when bread and groceries were con- sumed and then the risk caused by this product group turned into "high" at an age of 74.8; when milk and milk products were consumed, the risk became "high" at 74.9; the risk caused by bread and groceries became "extremely high" at 76 (Figure 1).

When we applied concentrations as per 90th percentile to assess combined introduction of contaminants ("pessimistic scenario of consumption"), the youngest age at which risk became "moderate" was also detected for bread and groceries and was equal to 41.2 years; the risk became "high" at 66.1 for this product group and "extremely high" at 70.4.

Our assessment of effects produced by contaminants on a body revealed that the most significant adverse effects were produced by cadmium, arsenic, and $\mathrm{HCCH}$; effects were primarily produced on the endocrine system (Figure 2).

We built evolution models for noncarcinogenic risks caused by exposure to contaminants for other organs and systems (the cardiovascular system, urogenital system, hematopoietic system, and immune system) and assessed them to be "negligible".

We also created evolution models for carcinogenic risks taking into account calculated consumption of bread and groceries; the risks were caused by adverse effects produced by cadmium, arsenic, $\mathrm{HCCH}$, and DDT and were calculated as per median concentrations and 90-th percentile. Both calculations allowed us to assess risks caused by the said contaminants to be "negligible".

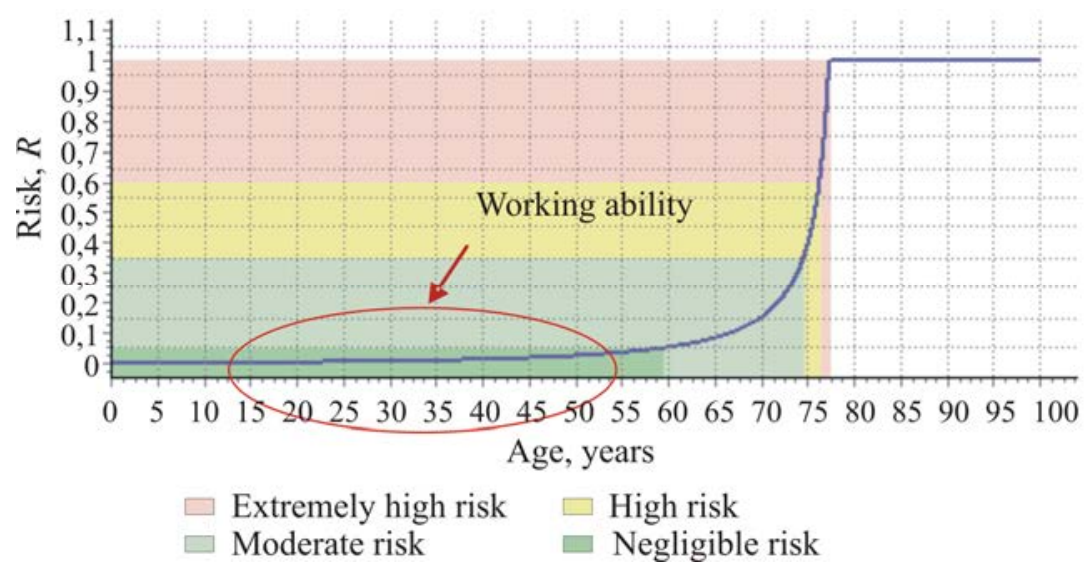

Figure 1. Reduced non-carcinogenic risk index for calculated consumption of bread and groceries 


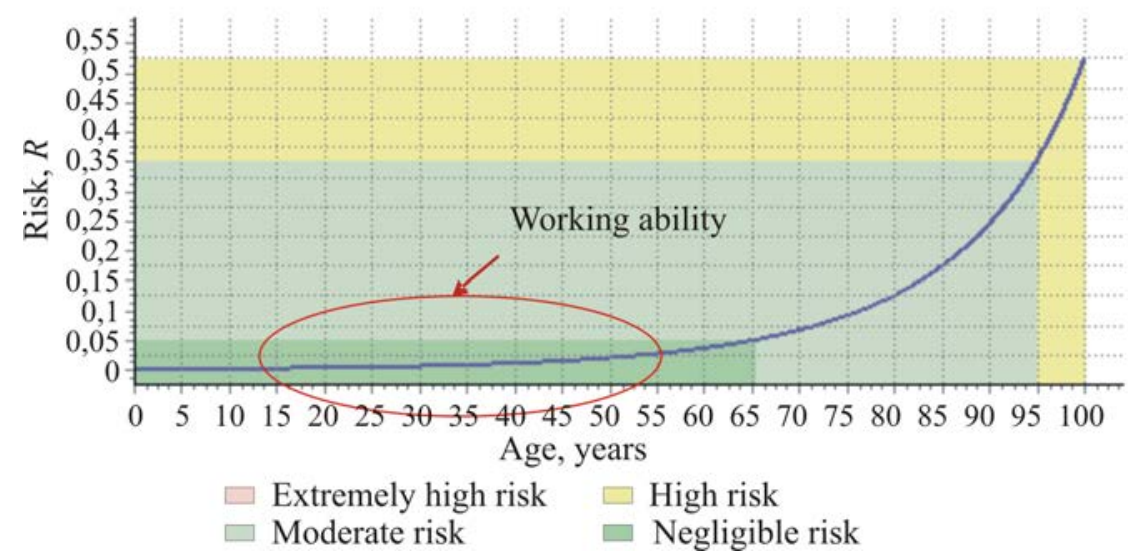

Figure 2. Reduced non-carcinogenic risk index (the endocrine system) for calculated consumption of bread and groceries

Conclusions. In order to assess risks in our research, we took data on individual average annual consumption of food products obtained via assessing actual nutrition consumed by employable population basing on a technique that reproduced a 24-hour nutrition scheme. The procedure that we propose allows maximum possible precision in determining impacts exerted by alimentary contaminants as it is not based on statistical data on average annual food products consumption per capita.

We revealed in our research that the maximum hazard quotient for non-carcinogenic effects was caused by arsenic being introduced with food. Total hazard index under combined exposure to the examined contaminants, both in their median and 90-th percentile concentrations, was predominantly caused by introduction of arsenic, cadmium, and nitrates contained in vegetables and melons, bread and groceries, milk and milk products, meat and meat products, fruits and berries. We detected that the endocrine system was the most susceptible to adverse effects produced by combined exposure to cadmium, mercury, lead, arsenic, and DDT, and it was also con- firmed by evolution models. We assessed carcinogenic risks caused by combined exposure to contaminants taking into account their median concentrations; the assessment revealed that risk level was within the third range; when 90-th percentile concentrations were considered, the risk was within the fourth range. We built evolution models for carcinogenic risks basing on calculated food products consumption and resulting contaminants contents both in their median concentrations and 90-th percentile and it allowed us to assess risks caused by the said effects as being "negligible".

Therefore, application of various methodical approaches to assessing risks caused by food products contamination revealed that the state system of sanitary-epidemiologic surveillance in Samara region provided all the necessary monitoring over safety and quality of food products, both domestically produced and imported ones, and made for preservation of population health.

Funding. The research was not granted any sponsor support.

Conflict of interests. The authors declare there is no any conflict of interests.

\section{References}

1. Frolova O.A., Tafeeva E.A., Frolov D.N., Bocharov E.P. Alimentary-dependent diseases of the population and the hygienic characteristic of the factors of the risk of their development in the territory of the republic of Tatarstan. Gigiena i sanitariya, 2018, vol. 97, no. 5, pp. 470-473 (in Russian).

2. Pastushkova E.V., Mysakov D.S., Chugunova O.V. Some aspects of nutrition and health. Zdorov'e i obrazovanie v XXI veke, 2016, no. 4, pp. 67-72 (in Russian). 
3. Lebedeva S.N., Zhamsaranova S.D., Chukaev S.A., Dymsheeva L.D. Assesment of the nutrition and antioxidant activity of biological liquids in students. Voprosy pitaniya, 2018, no. 1, pp. 35-43 (in Russian).

4. Mazhaeva T.V., Dubenko S.E., Pogozheva A.V., Khotimchenko S.A. Characteristics of the diet and nutritional status of workers at various industrial enterprises of the Sverdlovsk Region. Voprosy pitaniya, 2018, no. 1, pp. 72-78 (in Russian).

5. Evstratova V.S., Radzhabkadiev R.M., Khanfer'yan R.A. The structure of macronutrient consumption by the population of various regions of Russian Federation. Voprosy pitaniya, 2018, no. 2, pp. 34-38 (in Russian).

6. Boyarskaya L.A., Vil'ms E.A., Turchaninov D.V. Hygienic substantiation of application of functional dairy products in the prevention of macro- and micronutrient deficiency. Gigiena i sanitariya, 2016, vol. 95, no. 11, pp. 1095-1099 (in Russian).

7. Zhminchenko V.M., Gapparov M.M.G. Modern trends of research in nutritiology and nutrition hygiene. Voprosy pitaniya, 2015, no. 1, pp. 4-14 (in Russian).

8. Khotimchenko S.A., Bessonov V.V., Bagryantseva O.V., Gmoshinskii I.V. Safety of food products: new problems and ways of solution. Meditsina truda i ekologiya cheloveka, 2015, no.4, pp. 7-14 (in Russian).

9. Klepikov O.V., Khatuaev R.O., Istomin A.V., Rumyantseva L.A. Regional features of food standards and health risks associated with chemical contamination of food. Gigiena i sanitariya, 2016, vol. 95, no. 11, pp. 1086-1091 (in Russian).

10. Al-Saleh I., Abduljabbar M. Heavy metals (lead, cadmium, methylmercury, arsenic) in commonly imported rice grains (Oryza sativa) sold in Saudi Arabia and their potential health risk. Int. J. Hyg. Environ Health, 2017, vol. 220, no. 7, pp. 1168-1178. DOI: 10.1016/j.ijheh.2017.07.007

11. Fang Y., Sun X., Yang W., Ma N., Xin Z., Fu J., Liu X., Liu M. [et al.]. Concentrations and health risks of lead, cadmium, arsenic, and mercury in rice and edible mushrooms in China. Food Chem., 2014, vol. 15, no. 147, pp. 147-151. DOI: 10.1016/j.foodchem.2013.09.116

12. Jiang Y., Zeng X., Fan X., Chao S., Zhu M., Cao H. Levels of arsenic pollution in daily foodstuffs and soils and its associated human health risk in a town in Jiangsu Province, China. Ecotoxicol. Environ. Saf, 2015, no. 122, pp. 198-204. DOI: 10.1016/j.ecoenv.2015.07.018

13. Sadeghi F., Nasseri S., Yunesian M., Nabizadeh R., Mosaferi M., Mesdaghinia A. Carcinogenic and non-carcinogenic risk assessments of arsenic contamination in drinking water of Ardabil city in the Northwest of Iran. J. Environ. Sci. Health. A. Tox. Hazard Subst. Environ., 2018, vol. 53, no. 5, pp. 421-429. DOI: 10.1080/10934529.2017.1410421

14. Lamteva T.V., Velikaya L.V., Gaidukova E.P., Platunin A.V. About contamination by nitrates of crop production. Prikladnye informatsionnye aspekty meditsiny, 2018, no. 4, pp. 111-117 (in Russian).

15. Tutelyan V.A., Nikityuk D.B., Khotimchenko S.A. Normative base for food quality and safety assessment. Rossiiskii zhurnal vosstanovitel'noi meditsiny, 2017, no. 2, pp. 74-120 (in Russian).

16. Liu J., Zhuo Z., Sun S., Ning X., Zhao S., Xie W., Wang Y., Zheng L. [et al.]. Concentrations of heavy metals in six municipal sludges from Guangzhou and their potential ecological risk assessment for agricultural land use. Pol. J. Environ. Stud, 2015, vol. 24, no. 1, pp. 165-174. DOI: $10.15244 /$ pjoes $/ 28348$

17. Perez-Vazquez F.J., Flores-Ramirez R., Ochoa-Martínez A.C., Carrizales-Yanez L., Ilizaliturri-Hernandez C.A., Moctezuma-Gonzalez J., Pruneda-Alvarez L.G., Ruiz-Vera T. [et al.] Human health risks associated with heavy metals in soil in different areas of San Luis Potosi, Мехісою Hum. Ecol. Risk Assess, 2016, vol. 22, no. 2, pp. 323-336. DOI: 10.1080/10807039.2015.1064760

18. Kendir E., Kentel E., Sanin F.D. Evaluation of heavy metals and associated health risks in a metropolitan wastewater treatment plant's sludge for its land application. Hum. Ecol. Risk Assess. Int, 2015, vol. 21, no. 6, pp. 1631-1643. DOI: 10.1080/10807039.2014.966590

19. Chen T.B., Huang Q.F., Gao D. [et al.]. Heavy metal concentrations and their decreasing trends in sewage sludges of China. Acta Sci. Circumstantiate, 2003, no. 23, pp. 561-569.

20. Popova A.Yu. Risk analysis as a strategic sphere in providing food products safety. Health Risk Analysis, 2018, no. 4, pp. 4-12. DOI: 10.21668/health.risk/2018.4.01.eng 
21. Zaitseva N.V., Tutelyan V.A., Shur P.Z., Khotimchenko S.A., Sheveleva S.A. Experience of justification of hygienic standards of food safety with the use of criteria for the risk for population health. Gigiena i sanitariya, 2014, no. 5, pp. 70-74 (in Russian).

22. Zaitseva N.V., Popova A.Yu., May I.V., Shur P.Z. Methods and technologies of health risk analysis in the system of state management under assurance of the sanitation and epidemiological welfare of population. Gigiena i sanitariya, 2015, no. 2, pp. 93-98 (in Russian).

23. Zaitseva N.V. Analysis of population health risks in the Russian Federation caused by food products contamination. Health Risk Analysis, 2018, no. 4, pp. 13-23. DOI: 10.21668/health.risk/2018.4.02.eng

24. Zaitseva N.V., Shur P.Z., Kiryanov D.A., Kamaltdinov M.R., Tsinker M.Yu. Methodical approaches for health population risk estimation based evolution models. Zdorov'e naseleniya i sreda obitaniya, 2013, no. 1, pp. 4-6 (in Russian).

Gorbachev D.O., Sazonova O.V., Borodina L.M., Gavryushin M.Y. Analyzing health risks for employable population caused by food products contamination (experience gained in Samara region). Health Risk Analysis, 2019, no. 3, pp. 42-49. DOI: 10.21668/health.risk/2019.3.05.eng

Received: 25.06 .2019

Accepted: 26.07.2019

Published: 30.09.2019 
UDC 614.31.613.292.614.35.615.31.543.51.543.54.544.1.547.7.547.8

DOI: $10.21668 /$ health.risk/2019.3.06.eng

\section{SCREENING RESULTS FOR NON-DECLARED SYNTHETIC PHOSPHODIESTERASE-5 INHIBITORS BEING ADDED TO DIETARY SUPPLEMENTS OF PLANT ORIGIN}

\section{I.B. Perova, K.I. Eller, E.V. Tumol`skaya}

Federal research centre of nutrition and biotechnology, 2/14 Ustinskiy Proezd, Moscow, 109240, Russian Federation

Non-declared addition of synthetic phosphodiesterase-5 inhibitors (PDE-5 inhibitors) to dietary supplements (DS) of plant origin in order to stimulate potency is a serios problem. Such counterfeiting strengthens therapeutic effects produced by a product; similar effects can't occur only due to components of DS of plant origin. Synthetic PDE-5 inhibitors are both substances of official medications and their structural analogues. When synthetic PDE-5 inhibitors are consumed as components in DS in order to increase potency, it can be hazardous for consumers' health due to unpredictable or even lethal side effects.

Our research goal was to reveal concentrations of non-declared synthetic PDE-5 inhibitors in DS consumed by males. Our research objects were 175 DS selected by Rospotrebnadzor in different Russian regions. Synthetic PDE-5 inhibitors were detected in samples by HPLC with diode array spectrophotometric detection and MS-detection as per guidelines developed by us and approved on by Rospotrebnadzor (MG 4.1.3331-16).

Our research revealed that $36 \%$ of DS that were consumed to increase potency contained non-declared synthetic PDE-5 inhibitors with Tadalafil and Sildenafil being the most widely spread ones $42.9 \%$ and $28.6 \%$ of all counterfeit cases). Their combination or analogues of PDE-5 inhibitors were detected significantly less frequently; complicated mixtures containing three or more components were also rather rare. Contents of Tadalafil, Sildenafil, or Vardenafil in DS varied from trace quantities to concentrations that corresponded to recommended daily doses for these medications or even higher than such doses. We identified derivatives of Sildenafil and Tadalafil among PDE-5 inhibitors; their quantities varied from $1.2 \mathrm{mg} /$ capsule to $24.3 \mathrm{mg} / \mathrm{capsule}$.

The developed procedure allowed detecting counterfeited DS with not only Tadalafil, Sildenafil, or Vardenafil being added to them, but also analogues of synthetic PDE-5 inhibitors.

Key words: DS, safety, health risk, Synthetic phosphdiesterase-5 inhibitors, Tadalafil, Vardenafil, Sildenafil, HPLC-DAD-MS.

Vegetable biologically active additives (BAAs) to food that are used to stimulate potency are widely spread all over the world and considered to be safe. But it is such additives that are the most frequently falsified as they contain non-declared drug substances that are added to raise their stated efficiency. These additives are applied to stimulate potency in case there is overall weakening of a body but they are non-efficient in case of erective dysfunction (ED) which occurs due to diseases in the urogenital system. BAAs to food aimed at stimulating potency usually contain certain aphrodisiacs (extracts of barrenwort, ginseng, magnolia-vine, eleutherococcus, yohimbe, damiana, etc.), prostate protectors (extracts of cinquefoil, pumpkin seeds, palmetto, yam, licorice, ground burnuts, etc.), antioxidants (coenzyme $\mathrm{Q}_{10}$, extracts of maidenhair tree, tomatoes, Acai

(C) Perova I.B., Eller K.I., Tumol'skaya E.V., 2019

Irina B. Perova - Candidate of Pharmaceutical Sciences, Researcher at the Laboratory for Metabolomic and Proteome Analysis (e-mail: Erin.Feather@yandex.ru; tel.: +7 (495) 698-53-92; ORCID: https://orcid.org/0000-00015975-1376).

Konstantin I. Eller - Doctor of Chemical Sciences, Head of the Laboratory for Metabolomic and Proteome Analysis (e-mail: eller@ion.ru; tel.: +7 (495) 698-54-07;ORCID: https://orcid.org/0000-0003-1046-4442).

Elena V. Tumolskaya - Junior researcher at the Laboratory for Metabolomic and Proteome Analysis (e-mail: tum.elena@mail.ru; tel.: +7 (495) 698-53-92; ORCID: https://orcid.org/0000-0002-3913-0799). 
palm, etc.), vitamins (especially A, E, and $\mathrm{PP}$ ), and microelements (selenium, zinc and some others). At the same time accomplished research revealed that potencystimulating BAAs to food contained not only declared vegetable components but also synthetic phosphodiesterase-5 inhibitors (PDA-5 inhibitors).

These drugs are selective inhibitors of $\mathrm{c}-$ GMP-specific phosphodiesterase-5 (PDE-5) that metabolizes c-GMP into 5'-GMP in smooth muscles cells of blood vessels that supply blood to cavernous bodies of the penis (and artery walls in the lungs). PDE-5 blocking is accompanied with c-GMP accumulation and stronger and longer erection when sexual arousal occurs. So, PDE-5 inhibitors are applied to treat ED and pulmonary hypertension. At present there are four drugs belonging to PDE-5 inhibitors group that are registered in the RF: Sildenafil (Viagra $^{\circledR}$, Pfizer), Tadalafil (Sialis ${ }^{\circledR}$, ElliLilly), Vardenafil (Levitra ${ }^{\circledR}$, Bayer), and Udenafil
(Zidena $^{\circledR}$, Dong-A Pharmaceutical Co. Ltd) ${ }^{1}$. The latter is also registered in South Korea and Malaysia [1]. In the USA and EU there is another allowed drug in this group in addition to Tadalafil, Vardenafil, and Udenafil, namely Avanafil (Stendra ${ }^{\circledR}$, Vivus; Spedra ${ }^{\circledR}$, Mitsubishi Tanabe Pharma) [2]. There is another PDE-5 inhibitor allowed in South Korea; it is called Mirodenafil (Mvix ${ }^{\circledR}$, SK ChemicalsLifeScience) [1]. Lodenafil carbonate is applied in Brazil to treat ED $\left(\right.$ Helleva $^{\circledR}$, Cristália Produtos Quími-cose Farmacêuticos) [3]. Chemical structures of all the drugs from PDE-5 inhibitors group are shown in Figure 1.

In some cases falsified BAAs to food contained structural analogs of PDE-5 inhibitors that were not registered as pharmaceutical substances but produced the same pharmacological effects. Since 2003 a lot of research work has been accomplished with its focus on discovering and identifying various analogs of Sildenafil, Tadalafil, and

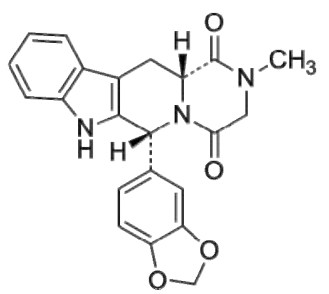

Tadalafil

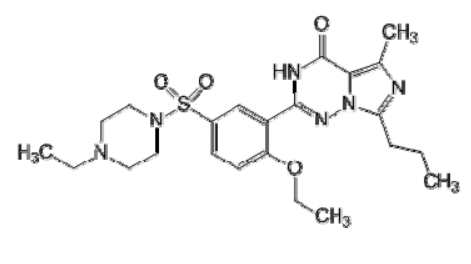

Vardenafil

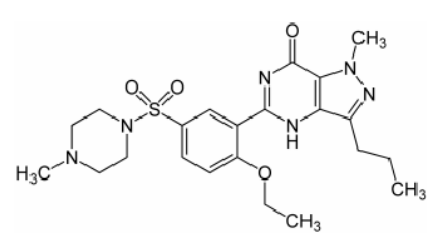

Sildenafil

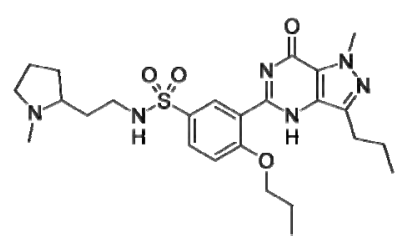

Udenafil

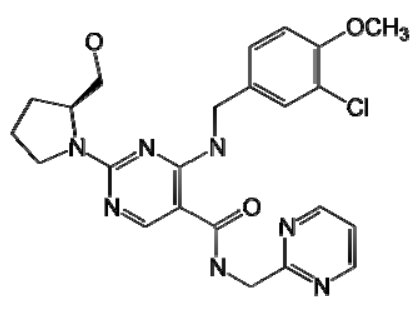

Avanafil

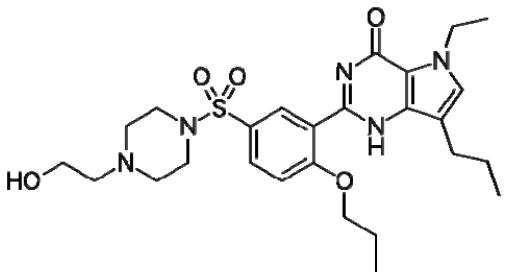

Mirodenafil

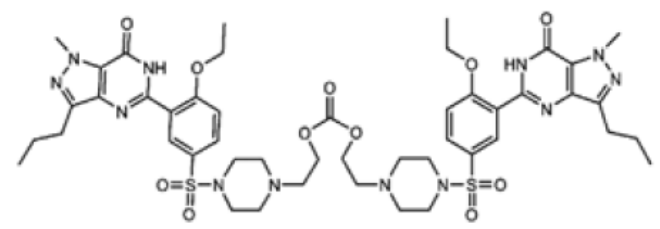

Lodenafil carbonate

Figure 1. Chemical structures of PDE-5 inhibitors

${ }^{1}$ The State Register of Medications. Available at: https://grls.rosminzdrav.ru/Default.aspx (date of visit March 23, 2019). 
Vardenafil via high-performance liquid chromatography (HPLC) with diode-array detector (DAD) and mass-spectrometric detectors with high and low resolution as well as infra-red spectroscopy and nuclearmagnetic resonance spectroscopy [4-32]. So, by 2018 approximately 80 synthetic PDE-5 inhibitors have been discovered in potencystimulating BAAs to food, Sildenafil analogs prevailing among them [33].

Synthetic substances that are illegally included into BAAs to food create substantial hazards for consumers' health. While there is available information on toxicity, counter-indications, side effects, and maximum single or daily dose for PDE-5 inhibitors allowed to be used in medical practices, there is practically no such information for most their analogs. Hypersensitivity to PDE5 inhibitors and simultaneous intake of nitrates or other nitrogen oxide donators are counter-indications to intake of these drugs. Safety precautions and limitations imposed on taking these drugs mostly concern men with cardiovascular diseases, diabetes, those who are older than 71 , men suffering from hereditary degenerative diseases of the eye retina, and those prone to priapism. Besides, quality, efficiency, and safety of PDE-5 inhibitors that are allowed to be used in medical practices are controlled by public healthcare authorities while there are no such procedures for illegally manufactured substances. Therefore, taking non-declared substances contained in BAAs to food can result in grave side effects, especially when it comes to analogs that have not been registered as pharmaceutical substances as their safety has never been examined and their interaction with other drugs can be unpredictable or even lethal.
Our research goal was to detect contents of non-declared synthetic PDE-5 inhibitors in potency-stimulating BAAs to food.

In order to protect population health and provide safety and quality of BAAs to food consumed by men, in 2015 Rospotrebnadzor started examining possible BAAs falsifications with synthetic PDE-5 inhibitors. Analytical tasks that are to be solved by test laboratories in order to perform control over potency-stimulating BAAs to food are rather complicated due to a great number of synthetic PDE-5 inhibitors (there are approximately 100 known substances and 80 of them have been detected in BAAs to food), standard substances being available, unfair manufacturers being too creative (they add exotic analogues and their mixtures into BAAs or include PDE-5 inhibitors into a cover of a capsule), and a great variety of BAAs matrixes. Given that, it has become necessary to develop a new methodology that would allow detecting synthetic PDE-5 inhibitors in a multi-component matrix of a BAA to food; it was the main task of our research.

Data and methods. We accomplished our research on Agilent 1100 liquid chromatographer with degasser, binary pump, column thermostat, constant-temperature autosampler, diode-array spectrophotometric detector (DAD), and time-of-flight Agilent 6210 LC/MS-TOF mass-spectrometric detector (Agilent Technologies, the USA); we also applied Ultimate 3000 system for liquid chromatography equipped with degasser, two three-channel pumps, column thermostat, constant-temperature autosampler, DAD, and TSQ Endura triple quadruple mass-spectrometric detector (Thermo Fisher Scientific, the USA).

\footnotetext{
${ }^{2}$ MUK 4.1.3331-16. The procedure for measuring a mass fraction of synthetic PDE-5 inhibitors (Tadalafil, Vardenafil, and Sildenafil) in biologically active additives to food via high-performance liquid chromatography with ultraviolet and mass-spectrometric detecting: Methodical guidelines. Available at: http://www.rospotrebnadzor.ru/documents/details.php?ELEMENT_ID=6314 (date of visit March 23, 2019).
} 
Our research objects were BAAs to food consumed by men including those applied to stimulate potency; BAAs were selected by Rospotrebnadzor experts in different RF regions. Overall, we analyzed 175 samples.

In order to solve tasks formulated by Rospotrebnadzor, we developed and metrologically tested a procedure for measuring a mass fraction of synthetic PDE-5 inhibitors (Tadalafil, Vardenafil, and Sildenafil) in biologically active additives via high-performance liquid chromatography with ultraviolet and mass-spectrometric detecting; in 2016 the procedure was granted a status of being the Methodical guidelines MUK 4.1.3331-16².

Results and discussion. Our research revealed that $36 \%$ of BAAs to food consumed by men contained non-declared synthetic PDE-5 inhibitors. We should note that we applied the fixed procedure for measuring a mass fraction of synthetic PDE-5 inhibitors and it allowed us to determine not only Tadalafil, Vardenafil, and Sildenafil in BAAs to food but also some analogs of drugs from PDE-5 inhibitors group with various chemical structures.

Detected BAAs falsifications with synthetic PDE-5 inhibitors are given in Figure 2.

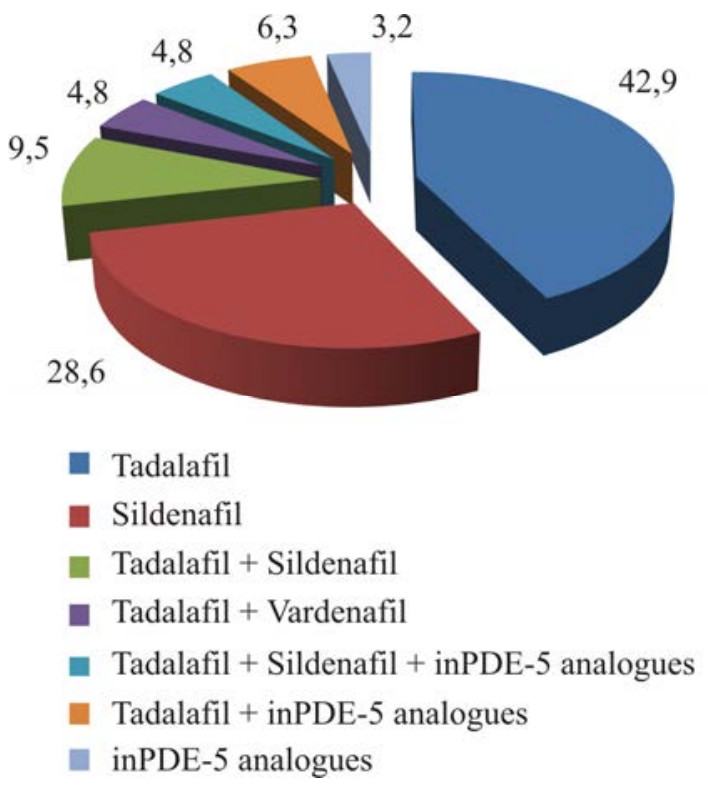

Figure 2. Distribution of BAAs falsifications with synthetic PDE-5 inhibitors (\%)
As we can see from Figure 2, Tadalafil and Sildenafil prevailed among non-declared PDE-5 inhibitors in BAAs to food $(42.9 \%$ and $28.6 \%$ of all falsifications respectively). Typical chromatograms of extractions from BAAs containing Tadalafil are given in Figure 3.

Tadalafil and Sildenafil combinations were less frequent $(9.5 \%)$; they were followed by combinations of Tadalafil with other synthetic PDE-5 inhibitors (6.3\%); combinations of Tadalafil and Vardenafil (4.8\%); and combinations of Tadalafil, Sildenafil, and other synthetic PDE-5 inhibitors $(4.8 \%)$. The rarest falsifications were those with structural analogs of drugs from PDE-5 inhibitors group as they accounted for only 3.2\%.

Quantity of non-declared synthetic PDE-5 inhibitors in BAAs to food varied greatly starting from trace concentrations $(0.004-1.0 \mathrm{mg} /$ capsule (pill, etc.)) that couldn't produce any pharmacological effects to concentrations comparable with recommended daily doses for respective drugs or being even higher than them (Table 1).

We identified derivatives of Sildenafil (Homosildenafil, Tiosildenafil, Hydroxyhomotiosildenafil), Tadalafil (Aminotadalafil), and Acetyldenafil (Metoxyacetyldenafil) among structural analogs of drugs from PDE-5 inhibitors group detected in BAAs to food.

Table 2 contains data on chemical structures of these substances, wave lengths of maximum absorptions in UV-part of a spectrum, molecular masses and protonated ion masses.

Hiomosildenafil was detected in BAAs to food in a quantity equal to $1.2-1.8 \mathrm{mg} / \mathrm{capsule}$ (pill) and it was combined with Tadalafil or Tadalafil and Sildenafil. A typical chromatogram for such a combination of PDE-5 inhibitors is shown in Figure 4.

Another falsification was a combination of Hydroxytiohomosildenafil in a concentration equal to $15.3 \mathrm{mg} /$ capsule and a derivative of Acetyldenafil with Tadalafil. The rarest falsification (only $3.2 \%$ of all falsification cases) was only one PDE-5 inhibitor analog added to a BAA to food; such analogs were either Tiosildenafil or Aminotadalafil and 
they were detected in concentrations equal to $24.3 \mathrm{mg} / \mathrm{capsule}$ and $12.2 \mathrm{mg} / \mathrm{capsule}$ respectively. As analogs of PDE-5 inhibitors have not been properly examined we don't have any available data on their single and daily pharmacological doses and it complicates assessment of risks caused by their contents in consumed BAAs to food.
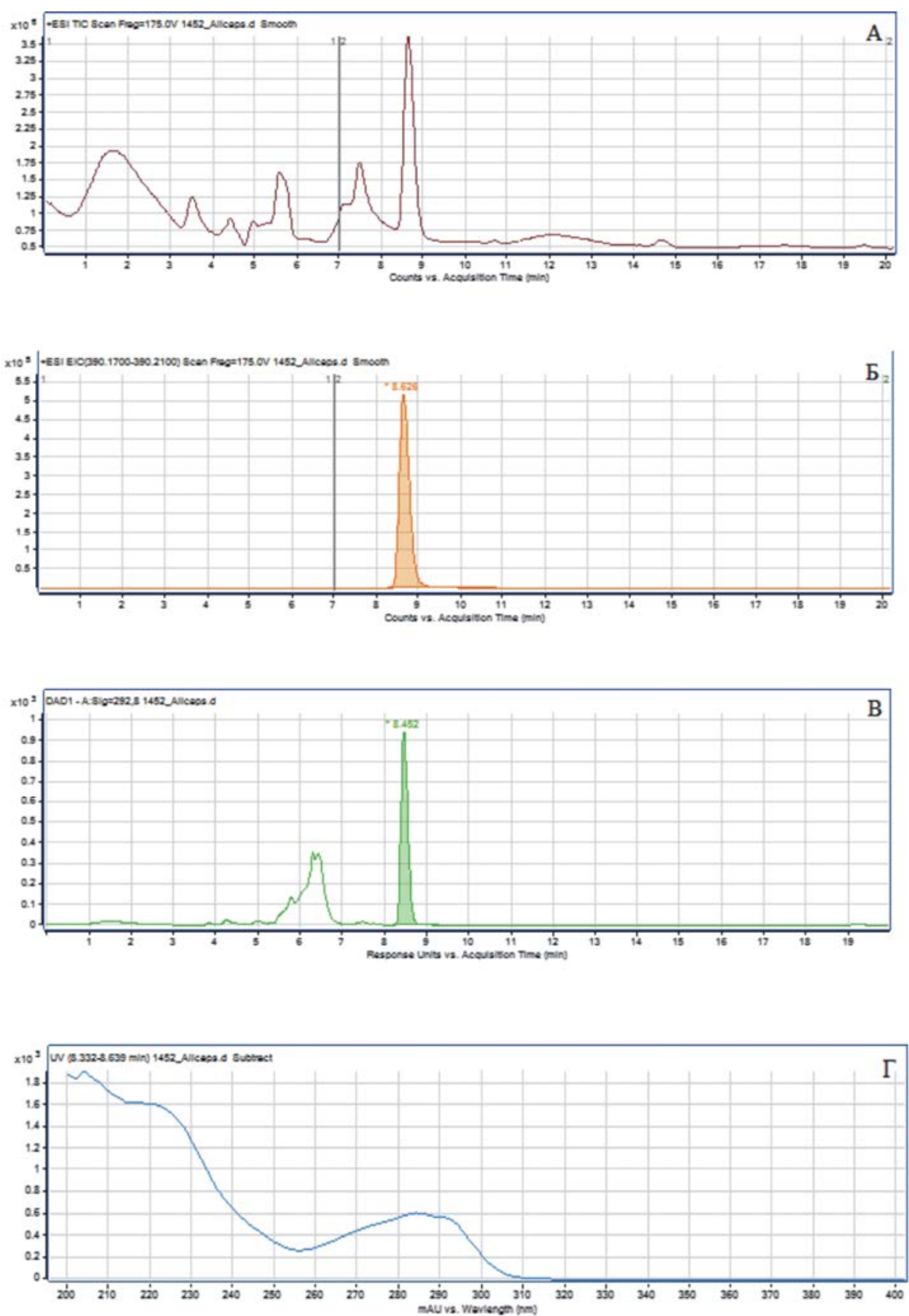

Figure 3. Chromatograms showing extractions from BAAs to food that contained Tadalafil. $A$ is total ion current (TIC). $\mathrm{B}$ is extracted ion chromatogram (EIC) of Tadalafil with $\mathrm{m} / \mathrm{z} 390$. $\mathrm{B}$ is a chromatogram showing extraction form a BAA to food at $\lambda=292 \mathrm{~nm}$. $\Gamma$ is an UV-spectrum of Tadalafil in a BAA to food 
Table 1

Recommended daily doses of Tadalafil, Sildenafil, and Vardenafil, and their quantities detected in examined BAAs to food

\begin{tabular}{|c|c|c|}
\hline $\begin{array}{c}\text { Substances from PDE-5 } \\
\text { inhibitors group }\end{array}$ & Recommended daily dose, mg & $\begin{array}{c}\text { Detected in a BAA to food, } \\
\text { mg/capsule (pill) }\end{array}$ \\
\hline Tadalafil & $5-20$ & $0.004-26.7$ \\
\hline Sildenafil & $25-100$ & $0.001-115.8$ \\
\hline Vardenafil & $5-20$ & $0.1-14.0$ \\
\hline
\end{tabular}

Table 2

Structure formulas, UV maximum absorptions, molecular masses, and protonated ion masses $[\mathrm{M}+\mathrm{H}]^{+}$of PDE-5 inhibitors analogs detected in BAAs to food

\begin{tabular}{|c|c|c|c|c|}
\hline $\begin{array}{c}\text { Analog of PDE-5 } \\
\text { inhibitor }\end{array}$ & Structure formula & $\lambda_{\max }, \mathrm{nm}$ & $\mathrm{M}, \mathrm{gr} / \mathrm{mol}$ & {$[\mathrm{M}+\mathrm{H}]^{+}$} \\
\hline Homosildenafil & & 294 & 488.6 & 489 \\
\hline Tiosildenafil & & 295,355 & 490.6 & 491 \\
\hline $\begin{array}{l}\text { Hydroxyhomotio- } \\
\text { sildenafil }\end{array}$ & & 295,355 & 520.6 & 521 \\
\hline Aminotadalafil & & $\begin{array}{l}270 \text { arm, } \\
284,292\end{array}$ & 390.39 & 391 \\
\hline Metoxyacetyldenafil & & $\begin{array}{l}230, \\
280\end{array}$ & 496.6 & 497 \\
\hline
\end{tabular}



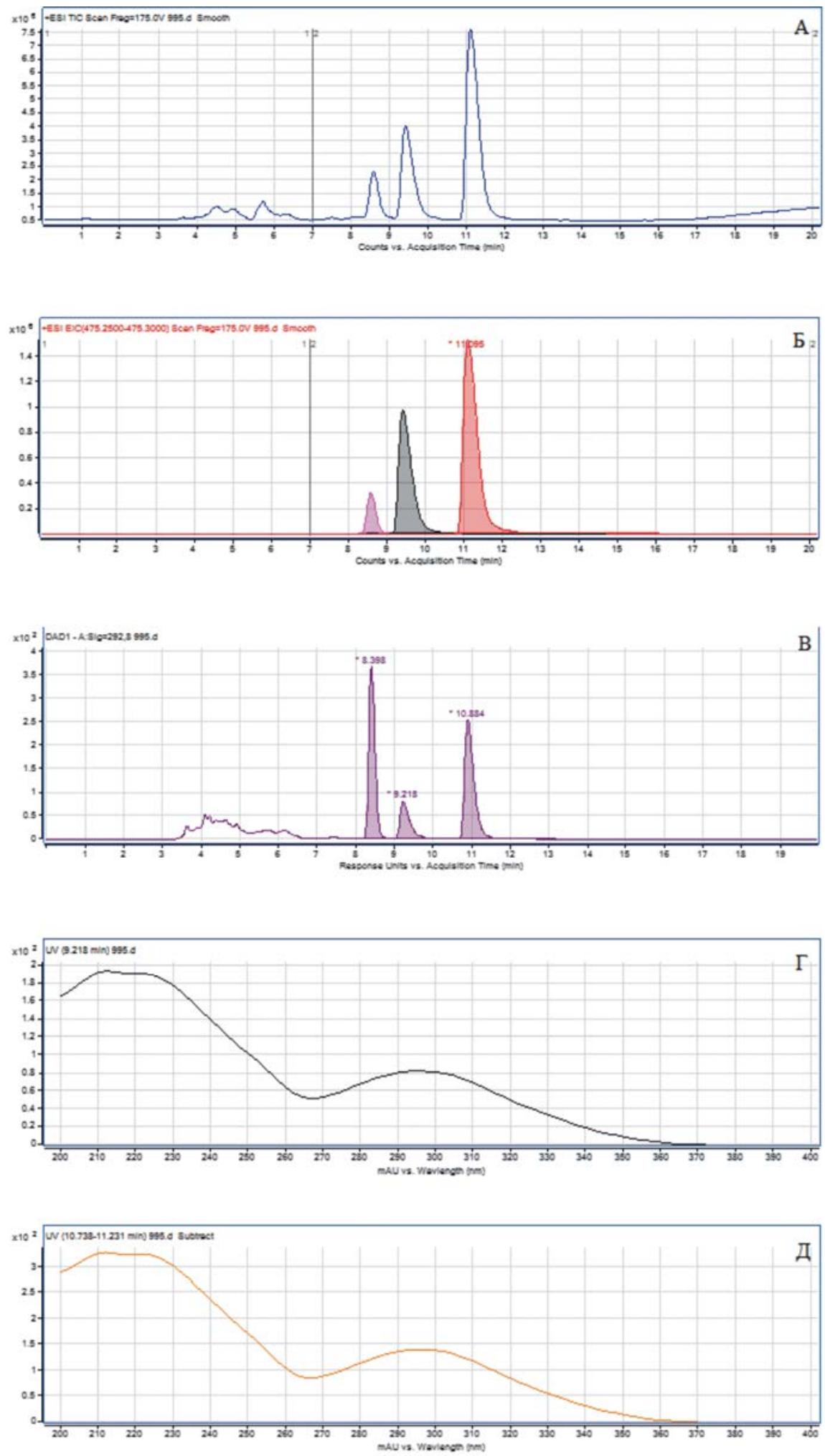

Figure 4. Chromatograms showing an extraction from a BAA to food that contained Tadalafil, Sildenafil, and Homosildenafil. A is total ion current (TIC). Б is extracted ions chromatogram (EIC) showing Tadalafil ions with $\mathrm{m} / \mathrm{z} 390$ (8.6 minutes), Homosildenafil ions with $\mathrm{m} / \mathrm{z} 489$ (9.4 minutes), and Sildenafil ions with $\mathrm{m} / \mathrm{z} 475$ (11.1 minutes). B is a chromatogram of extraction from a BAA to food at $\lambda=292 \mathrm{~nm}$.

Retention time amounts to 8.4 minutes for Tadalafil; 9.2 minutes, for Homosildenafil; and 10.9 minutes, for Sildenafil. $\Gamma$ is an UV-spectrum of Homosildenafil in a BAA to food. Д is an UV-spectrum of Sildenafil in a BAA to food 
Conclusions. Our research revealed that the fixed procedure allowed detecting concentrations of not only Tadalafil, Vardenafil, and Sildenafil, but also some structural analogs of drugs from PDE-5 inhibitors group. Obtained data are applied when a BAA to food is certified by state authorities. In particular, a sanitary-epidemiologic inspection of a potencystimulating BAA to food obligatorily includes checking whether a BAA to food contains non-declared synthetic PDE-5 inhibitors. Research results can be considered a database necessary for assessing potential health risks.

Funding. The research was not granted any financial support.

Conflict of interests. The authors declare there is no any conflict of interests.

\section{References}

1. Moon D.G. Evolution of PDE5 inhibitors in Korea. Transl. Androl. Urol., 2015, vol. 4, no. 1, pp. AB041. DOI: 10.3978/j.issn.2223-4683.2015.s041

2. Huang S.A., Lie J.D. Phosphodiesterase-5 (PDE-5) inhibitors in the management of erectile dysfunction. Pharmacy and Therapeutics, 2013, vol. 38, no. 7, pp. 414-419.

3. Peak T.C., Yafi F.A., Sangkum P., Hellstrom W.J.G. Emerging drugs for the treatment of erectile dysfunction. Expert Opinion on Emerging Drugs, 2015, vol. 20, pp. 263-275.

4. Shin M.H., Hong M.K., Kim W.S., Lee Y.J., Jeong Y.C. Identification of a new analogue of sildenafil added illegally to a functional food marketed for penile erectile dysfunction. Food Addit. Contam., 2003, vol. 20, no. 9, pp. 793-796.

5. Blok-Tip L., Zomer B., Bakker F., Hartog K.D., Hamzink M., Ten Hove J., Vredenbregt M., De Kaste D. Structure elucidation of sildenafil analogues in herbal products. Food Addit. Contam., 2004, vol. 21, no. 8, pp. 737-748. DOI: 10.1080/02652030412331272467

6. Zou P., Oh S.S., Hou P., Low M.Y., Koh H.L. Simultaneous determination of synthetic phosphodiesterase- 5 inhibitors found in a dietary supplement and pre-mixed bulk powders for dietary supplements using high-performance liquid chromatography with diode array detection and liquid chromatography-electrospray ionization tandem mass spectrometry. J. Chromatogr. A, 2006, vol. 1104, no. 1-2, pp. 113-122. DOI: 10.1016/j.chroma.2005.11.103

7. Park H.J., Jeong H.K., Chang M.I., Im M.H., Jeong J.Y., Choi D.M., Park K., Hong M.K. [et al.]. Structure determination of new analogues of vardenafil and sildenafil in dietary supplements. Food Addit. Contam., 2007, vol. 24, no. 2, pp. 122-129. DOI: 10.1080/02652030600983625

8. Lam Y.H., Poon W.T., Lai C.K., Chan A.Y., Mak T.W. Identification of a novel vardenafil analogue in herbal product. J. Pharm. Biomed. Anal., 2008, vol. 46, no. 4, pp. 804-807. DOI: 10.1016/j.jpba.2007.12.004

9. Zou P., Hou P., Oh S.S.Y., Ge X., Bloodworth B.C., Low M.Y., Koh H.L. Identification of benzamidenafil, a new class of phosphodiesterase- 5 inhibitor, as an adulterant in a dietary supplement. J. Pharm. Biomed. Anal., 2008, vol. 47, no. 2, pp. 255-259. DOI: 10.1016/j.jpba.2008.01.004

10. Reepmeyer J.C., d'Avignon D.A. Structure elucidation of thioketone analogues of sildenafil detected as adulterants in herbal aphrodisiacs. J. Pharm. Biomed. Anal., 2009, vol. 49, no. 1, pp. 145-150. DOI: $10.1016 /$ j.jpba.2008.10.007

11. Balayassac S., Trefi S., Gilard V., Malet-Martino M., Martino R., Delsuk M.A. 2D and 3D DOSY 1H-NMR, a useful tool for analysis of complex mixtures: application to herbal drugs or dietary supplements for erectile dysfunction. J. Biomed. Anal., 2009, vol. 50, no. 4, pp. 602-612. DOI: 10.1016/j.jpba.2008.10.034

12. Lee H.M., Kim C.S., Yang Y.M., Kwon S.W., Lee B.J. Separation and structural elucidation of a novel analogue of vardenafil included as an adulterant in a dietary supplement by liquid chromatography-electrospray ionization mass spectrometry, infrared spectroscopy and nuclear magnetic resonance spectroscopy. J. Pharm. Biomed. Anal., 2011, vol. 54, no. 3, pp. 491-496. DOI: 10.1016/j.jpba.2010.09.022

13. Venhuis B.J., Zomer G., Hamzink M., Meiring H.D., Aubin Y., De Kaste D. The identification of a nitrosatedprodrug of the PDE-5 inhibitor aildenafil in a dietary supplement: A Viagra with a pop. J. Pharm. Biomed. Anal., 2011, vol. 54, no. 4, pp. 735-741. DOI: 10.1016/j.jpba.2010.11.020 
14. Lee H.M., Lee B.J. A novel approach to simultaneous screening and confirmation of regulated pharmaceutical compounds in dietary supplements by LC/MS/MS with an informationdependent acquisition method. Food Addit. Contam. Part. A. Chem. Anal. Control Expo. Risk assess, 2011, vol. 28, no. 4, pp. 396-407. DOI:10.1080/19440049.2011.551947

15. Sacré P.Y., Deconinck E., Chiap P., Crommen J., Mansion F., Rozet E., Courselle P., De Beer J.O. Development and validation of a ultra-high-performance liquid chromatography-UV method for detection and quantification of erectile dysfunction drugs and some of their analogues found in counterfeit medicines. J. Chromarogr. A, 2011, vol. 1218, no. 37, pp. 6439-6447. DOI: 10.1016/j.chroma.2011.07.029

16. Balayssac S., Gilard V., Zedde C., Martino R., Malet-Martino M. Analysis of herbal dietary supplements for sexual performance enhancement: first characterization of propoxyphenyl-thiohydroxyhomosildenafil and identification of sildenafil, thiosildenafil, phentolamine and tetrahydropalmatine as adulterants. J. Pharm. Biomed. Anal., 2012, vol. 63, pp. 135-150. DOI: 10.1016/j.jpba.2012.01.035

17. Vaysse J., Gilard V., Balayssac S., Zedde C., Martino R., Malet-Martino M. Identification of a novel sildenafil analogue in an adulterated herbal supplement. J. Pharm. Biomed. Anal., 2012, vol. 59, pp. 58-66. DOI:10.1016/j.jpba.2011.10.001

18. Sakamoto M., Moriyasu T., Minowa K., Kishimoto K., Kadoi H., Hamano T., Fukaya H. Structure elucidation of a novel analog of sildenafil detected as an adulterant in a dietary supplement using LC-UV and LC/MS. Journal of AOAC International, 2012, vol.95, no. 4, pp. 1048-1052.

19. Liao Y.-C., Lai K.-C., Lee C., Liu Y.-C., Lin Y.-L., Shin D.Y.-C. Isolation and identification of new sildenafil analodues from dietary supplements. Journal of Food and Drug Analysis, 2013, vol. 21, no. 1, pp. 40-49. DOI:10.6227/jfda.2013210105

20. Campbell N., Clark J.P., Stecher V.J., Thomas J.W., Callanan A.C., Donnelly B.F., Goldstein I., Kaminetsky J.C. Adulteration of purported herbal and natural sexual performance enhancement dietary supplements with synthetic phosphodiesterase type 5 inhibitors. J. Sex. Med., 2013, vol. 10, no.7, pp. 1842-1849. DOI:10.1111/jsm.12172

21. Silva L.M., Filho E.G., Thomasi S.S., Silva B.F., Ferreira A.G., Venancio T. Use of diffusion-ordered NMR spectroscopy and HPLC-UV-SPE-NMR to identify undeclared synthetic drugs in medicines illegally sold as phytotherapies. Magn. Reson. Chem., 2013, vol. 51, no. 9, pp. 541-548. DOI:10.1002/mrc.3984

22. Lee E.S., Lee J.H., Kim J.W., Hwang I.S., Cho S., Han S.Y., Kim J. Simultaneous determination of 38 phosphodiesterase-5 inhibitors in illicit erectile dysfunction products by liquid chromatography-electrospray ionization-tandem mass spectrometry. J. Pharm. Biomed. Anal., 2013, vol. 83, pp. 171-178. DOI: 10.1016/j.jpba.2013.05.009

23. Reeuwijk N.M., Venhuis B.J., De Kaste D., Hoogenboom L.A.P., Rietjens I.M.C.M., Martena M.J. Sildenafil and analogous phosphodiesterase type 5 (PDE 5) inhibitors in herbal food supplements sampled on the Dutch market. Food Additives and Contaminants: Part A, 2013, vol. 30, no. 12, pp. 2027-2034. DOI:10.1080/19440049.2013.848294

24. Mustazza C., Borioni A., Rodomonte A.L., Bartolomei M., Antoniella E., Di Martino P., Valvo L., Sestili I. [et al.]. Characterization of sildenafil analogs by MS/MS and NMR: a guidance for detection and structure elucidation of phosphodiesterase-5 inhibitors. Journal of Pharmaceutical and Biomedical Analysis, 2014, vol. 96, pp. 170-186. DOI: 10.1016/j.jpba.2014.03.038

25. Patel D.N., Li L., Ge X.W., Low M.-Y., Koh H.-L. Screening of synthetic PDE-5 inhibitors and their analogues as adulterants: analytical techniques and challenges. J. Pharm. Biomed. Anal., 2014, vol. 87, pp. 176-190. DOI:10.1016/j.jpba.2013.04.037

26. Shi F., Guo C., Gong L., Li J., Dong P., Zhang J. Application of a high resolution benchtopquadrupole-Orbitrap mass spectrometry for the rapid screening, confirmation and quantification of illegal adulterated phosphodiesterase- 5 inhibitors in herbal medicines and dietary supplements. Journal of Chromatography A, 2014, vol. 1344, pp. 91-98. DOI: 10.1016/j.chroma.2013.12.030

27. Ulloa J., Sambrotta L., Redko F., Mazza O.N., Garrido G., Becher E.F., Muschietti L. Detection of a tadalafil analogue as an adulterant in a dietary supplement for erectile dysfunction. The Journal of Sexual Medicine, 2015, vol. 12, no. 1, pp. 152-157. DOI:10.1111/jsm.12759 
28. Rocha T., Amaral J.S., Oliveira P.B.P.P. Adulteration of dietary supplements by the illegal addition of synthetic drugs: A review. Compr. Rev. Food Sci. F, 2016, vol. 15, pp. 43-62.

29. Redko F., Flor S., Lucangioli S., Ulloa J., Ricco R., Fernandez C., Sambrotta L., Muschietti L. Identification and quantification of an adulterant in a dietary supplement marketed for sexual enhancement. Journal of Advanced Pharmaceutical Science and Technology, 2018, vol. 1, no. 4, pp. 25-33. DOI: 10.14302/issn.2328-0182.japst-18-2344

30. Tucker J., Fisher T., Upjohn L., Mazzera D., Kumar M. Unapproved pharmaceutical ingredients included in dietary supplements associated with US Food and Drug Administration warnings. JAMA Network Open, 2018, vol. 1, no. 6, pp. e183337. DOI: 10.1001/jamanetworkopen.2018.3337

31. Wang X.-B., Zheng J., Li J.-J., Yu H.-Y., Li Q.-Y., Xu L.-H., Liu M.-J., Xian R.-Q. [et al.]. Simultaneous analysis of 23 illegal adulterated aphrodisiac chemical ingredients in health foods and Chinese traditional patent medicines by ultrahigh performance liquid chromatography coupled with quadrupole time-of-flight mass spectrometry. Journal of Food and Drug Analysis, 2018, vol. 26, no. 3, pp. 1138-1153. DOI: 10.1016/j.jfda.2018.02.003

32. Vanhee C., Tuenter E., Kamugisha A., Canfyn M., Moens G., Courselle P., Pieters L., Deconinck E., V.Exarchou. Identification and quantification methodology for the analysis of suspected illegal dietary supplements: reference standard or no reference standard, that's the question. J. Forensic. Toxicol. Pharmacol., 2018, vol. 7, no. 1, pp. 7. DOI:10.4172/2325-9841.1000156

33. Kee C.L., Ge X., Gilard V., Malet-Martino M., Low M.Y. A review of synthetic phosphodiesterase type 5 inhibitors (PDE-5i) found as adulterants in dietary supplements. J. Pharm. Biomed. Anal., 2018, vol. 147, pp. 250-277. DOI:10.1016/j.jpba.2017.07.031

Perova I.B., Eller K.I., Tumol skaya E.V. Screening results for non-declared synthetic phosphodiesterase-5 inhibitors being added to dietary supplements of plant origin. Health Risk Analysis, 2019, no. 3, pp. 50-59. DOI: 10.21668/health.risk/2019.3.06.eng

Received: 29.08 .2019

Accepted: 02.09.2019

Published: 30.09 .2019 
UDC 577.161.2:616.832-004.2

DOI: $10.21668 /$ health.risk/2019.3.07.eng

\title{
ENVIRONMENTAL FACTORS IN MULTIPLE SCLEROSIS, FOCUSING EXPOSURE TO ORGANIC SOLVENTS
}

\author{
I. Boström ${ }^{1}$, T. Riise ${ }^{2,3}$, K. Björnevik ${ }^{2,3}$, K.-M. Myhr ${ }^{2,3}$, \\ M. Pugliatti ${ }^{2,4}$, C. Wolfson ${ }^{5}$, A.-M. Landtblom ${ }^{1,6}$ \\ ${ }^{1}$ University of Linköping, Linköping, SE-581 83, Sweden \\ ${ }^{2}$ University of Bergen, 31, Kalfarveien, 5020, Bergen, Norway \\ ${ }^{3}$ The Norwegian Multiple Sclerosis Competence Center, Haukeland University Hospital, 5020, Bergen, 7804, Norway \\ ${ }^{4}$ University of Ferrara, Via Ludovico Ariosto 35, 44121 Ferrara, Italy \\ ${ }^{5}$ Research Institute of the McGill University Health Centre, Purvis Hall, 1020 Pine Avenue West Montreal, QC, Canada \\ ${ }^{6}$ Uppsala University, 75185 Uppsala, Sweden
}

Results obtained in previous studies on the relationship between exposure to organic solvents and risk of multiple sclerosis are not entirely consistent.

The aim of this study was to investigate the relationship between exposure to organic solvents and risk of multiple sclerosis and possible interactions between exposure to solvents and smoking; exposure to solvents and infectious mononucleosis; exposure to solvents and D-vitamin.

The case-control study on Evironmental Factors In Multiple Sclerosis (EnvIMS) was used. We examined two samples, the first one made up of 1.197 MS patients, and the second one, 2.361 healthy controls from Sweden and Norway; both group were matching in terms of their sex and age. We examined their exposure to organic solvents prior to the study; we also examined whether they had suffered from infectious mononucleosis, their outdoor activity (D-vitamin) and smoking status. The relationships between exposure to solvents and other risk factors were estimated as odds ratios (ORs) with $95 \%$ confidence interval (95\% CI) using logistic regression.

Exposure to organic solvents was found to be associated with an increased MS risk, OR 1.51 (95\% confidence interval (CI): 1.19-1.90; $p=0.001$ ), adjusted OR was 1.36 (95\% CI: 1.05-1.75; $p=0.020$ ). Adjusted ORs for different combinations including exposure to solvents and other risk factors such as smoking, infectious mononucleosis and D-vitamin showed an increased risk of MS. Among those who reported infectious mononucleosis there was no increased risk associated with exposure to solvents, OR 1.03 (95\% CI: 0.48-2.19).

The increased risk seems to be present only in individuals with unfavorable smoking status and low D-vitamin status.

Keywords: multiple sclerosis, risk factors, organic solvent, smoking, infectious mononucleosis, D-vitamin.

Several environmental factors have been demonstrated to increase the risk of developing multiple sclerosis (MS), such as Epstein Barr infection (EBV), smoking [1], low levels of vitamin D [2] and sun exposure, and obesity [3]. Landtblom et al also investigated if there were any appears to be an exposure time window of vulnerability for example regarding Epstein Barr infection after childhood and obesity in adolescence. For some risk factors there appears to exposure time window of vulnerability for example regarding Epstein

(C) Boström I., Riise T., Björnevik K., Myhr K.-M., Pugliatti M., Wolfson C., Landtblom A.-M., 2019

Inger Boström - PhD, Post doc, Division of Neurology, Department of Clinical and Experimental Medicine (e-mail: inger.bostrom@liu.se).

Trond Riise - Prof, Department of Global Public Health and Primary Care (e-mail: trond.riise@uib.no).

Kjetil Björnevik - PhD, Department of Global Public Health and Primary Care (e-mail: kjetil.bjornevik@uib.no).

Kjell-Morten Myhr - Prof, The Kristian Gerhard Jebsen Centre for MS-research, Department of Clinical Medicine (e-mail: kjell-morten.myhr@uib.no).

Maura Pugliatti - Ass Prof, Department of Biomedical and Specialty Surgical Science, Section of Clinical Neurology (e-mail: maura.pugliatti@unife.it).

Christina Wolfson - Prof, Department of Epidemiology and Biostatistics and Occupational Health (e-mail: christina.wolfson@mcgill.ca).

Anne-Marie Landtblom - Prof, Department of Neuroscience/Neurology (e-mail: anne-marie.landtblom@neuro.uu.se). 
Barr infection after childhood and obesity in adolescence [4].

Studies regarding solvents started early on with the observations of Amaducci in shoemakers in Florence. Eventually series of case control studies were performed, many of which seemed to suggest an odd ratio of about 2. Flodin [et al.] [5] and Landtblom [et al.] [6] saw an increased risk for MS in men due to occupational exposure to solvents, particularly in combination with welding in case-control studies.

An early meta-analysis of thirteen small studies in 1996 showed an association between organic solvents and MS in ten of them with about a two-folded risk of MS in exposed individuals [7]. They found no clinical differences between the two groups but there was a significant higher proportion of the exposed MS-patients who had hypointensity in basal ganglia on MRI compared to unexposed, although some of the unexposed MS-patients also had hypointensity in their basal ganglia [8].

Lantblom [et al.] compered MS-patients exposed to organic solvents with unexposed MS-patients to see if there was a difference in their metabolization of organic solvents. They investigated the occurrence of patients with GSTM1null and CYP2D6 poor metabolizers in the two groups but saw no difference between the exposed and unexposed group [9]. A big register study on occupational exposure in men between 1970 to 1980 saw no association between MS and occupational exposure [10]. A recent casecontrol study found no association between exposure to organic solvents and MS [11].

A review by Barragán-Martínez [et al.] in 2012 investigated the association between organic solvents and autoimmune diseases and saw an association between organic exposure and primary systemic vasculitis, systemic sclerosis and multiple sclerosis. Fifteen studies on MS and exposure to various organic solvents were included [12], about half of them was also included in the review by Landtblom et al in 1996. BarragánMartínez [et al.] found a slight but significantly increased risk of developing MS after exposure to organic solvents, the odds ratio calculated to $1,53(95 \% \mathrm{Cl}: 1,03-2,29)$ [12].

Since many anesthetics are related to organic solvents and trichloroethylene (TCE) previously have been used as an anesthetic [13] some groups have investigated if there is an association between exposure to anesthetics and an increased risk of MS. In 1988 Noseworthy reported two patients with TCE poisoning initially diagnosed as MS due to their fluctuation of symptoms. Both patients had normal MRI and clinic did not fully support MS [14]. A big study of marines exposed to mainly TCE and tetrachloroethylene in drinking water between 1975 and 1985 showed no association to MS. The levels of TCE were lower than the estimated exposure in industry at the same period and the time of exposure was relatively short [15]. Landtblom [et al.] noted a trend towards a higher cumulative incidence of MS in anesthetic nurses compered to teachers, only significant in the 1990-2000 strata and an almost two-fold non-significant risk compared to other nurses [16]. On the other hand, Stenager et al could not find an increased risk of MS among anesthetic nurses compared to the expected incidence in a matched population [17]. Nor did Hedström [et al.] in a later study where they also looked at anesthetic nurses exposed before 1985 as a separate group [18].

In a recently presented article by Hedström [et al.], a significantly increased risk of MS was shown after exposure of organic solvents, OR 1.5 (95\% CI 1.2-1.8). They have also analysed ORs for different combinations of genetic risk factors (DRB $1 * 15$ and

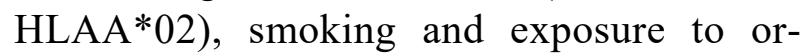
ganic solvents. An OR of 30.3 was seen when participants, carrying HLA-DRB $1 * 15$ and lacking HLA-A*02, were exposed to organic solvents and smoking in combination. However, it can be pointed out that the num- 
ber of cases and controls was quite little 40 respective 5 [19].

The purpose of this study was to analyze the risk for MS after exposure to organic solvents and possible interactions between solvent exposure and smoking; solvent exposure and EBV; solvent exposure and D-vitamin.

Methods. Study design. Our study is a part of the International multicenter casecontrol study of Environmental Factors in Multiple Sclerosis (EnvIMS). The EnvIMS aims to investigate the effects of self-reported exposure of risks, environmental issues and lifestyle in early stages of life to disease outbreaks in MS and to reveal possible risk differences between distinct populations using a common method. It has been carried out in well-defined geographic areas in Europe (Norway, Italy, Serbia and Sweden) and in Canada. Details of study design and methodology in EnvIMS have previously been reported by Magalhaes [et al.] [20].

Study population and area. The current study includes participants from Sweden and Norway aged 18 years or older at the time of selection. The cases were recruited from population-based MS registries. Four times as many age and sex frequency-matched controls were randomly selected from the population registries of each region under study. The response rates among the cases were $68 \%$ and $70 \%$ for Sweden and Norway respectively. The response rates among the controls were similar in Sweden and Norway (37\% and $36 \%$ ).

Exposure. Exposure information was collected through a novel, self-administered questionnaire. Ten questions about occupational exposure: engine oil, cutting oil, form oil, hydraulic oil, turbine oil, asphalt, drilling mud, crude oil, anesthetic gases and organic solvents (e.g. thinner, tri, trichloroethylene, lacquer naphtha, toluene, styrene, xylene or the like) were reported as «no», «don't know» and «yes». They reported age when exposure started, during how many years they were exposed and in what kind of work.
Smoking habits were reported as «ever» and «never» smoker, age at smoking initiation, total years of smoking and number of cigarettes per day in different age groups between 11 to 30 years.

EBV infection was measured as a positive history of infectious mononucleosis (IM) answered as «yes», «no» and «don't remember». They also reported which age period the disease was contracted.

As an indication of D-vitamin status there were questions about outdoor activity rated as «little (1)», «medium (2)», «pretty much (3)», «out almost all the time (4)», in age groups.

Statistical analysis. The association between disease and exposure was estimated as OR with $95 \%$ confidence interval $(95 \% \mathrm{CI})$ using logistic regression. All controls were randomly assigned an index age based on the distribution of age of disease onset in the cases. Events or reported behavior occurring after the age of MS onset or index age were not considered as exposure. The exposure time for solvents, smoking and IM must have occurred before onset of MS. All analyses were adjusted for age and sex.

To account for outdoor activity throughout adolescence the age periods «16-18» were used, which in previous studies from EnvIMS has shown been the most relevant MS risk. The values in the original variables (ranging from 14) were added and the new variable took value «Low D-vitamin» (rate 1-2) and «High D-vitamin» (rate 3-4).

Results. A total of 3558 people's answers are involved this study, 1197 cases and 2361 controls. The occupational questions about organic solvents were answered in total by 3457 individuals (97.2\%). «Yes» by 408 persons «No» by 2926, «Don't know» by 123 and there were 101 missing. Higher proportion of men than women has reported that they have been exposed of organic solvent.

In total the question about smoking was answered by 3461 persons (97.3\%). «Yes» 
by 1879 persons «No» by 1582 and there were 97 missing.

A total of 3447 (96.9\%) answered the question of IM, «Yes» by 403, «No» by 2872 and «Don't remember»172, missing 111. Outdoor activity answered by 3463 persons (97.3\%).

Exposure to organic solvents was found to be associated with MS in the pooled data from Sweden and Norway. The OR for risk of MS was 1.51 (95\% CI: 1.19-1.90, $\mathrm{p}=0.001)$, adjusted to IM, smoking and outdoor activity (vitamin D-level) the OR was 1.36 (95\% CI: $1.05-1.75, \mathrm{p}=0.020)$. In men the OR was 1.42 (95\% CI: 1.002.02, $\mathrm{p}=0.050$ ), in women 1.24 (95\% CI: 0.85-1.82, $\mathrm{p}=0.267$ ).

A calculation of the ORs associated with different combinations of solvent exposure and smoking, solvent exposure and IM; solvent exposure and D-vitamin showed an increased risk of MS. Cases with expo- sure to organic solvents and smoking the OR was $3.2(95 \% \mathrm{CI}: 2.36-4.36, \mathrm{p}=0.000)$; organic solvents and low D-vitamin had an OR 2.87 (95\% CI: 2.02-4.10, p = 0.000), Table 1.

Table 2 shows the effect of interaction providing the effect estimates for each of the three exposures variables (smoking, infectious mononucleosis (IM), D-vitamin level) stratified on exposure of organic solvents. The estimates for smokers and low D-vitamin show a significantly increased risk. In those who reported no history of IM there was a significantly increased risk.

Discussion. It is interesting to consider possible mechanisms that may be related to the effect of solvent exposure in MS. An effect on the blood brain barrier has been proposed as a cause of the increased risk, possibly opening for immunocompetent cells to enter the central

Table 1

Adjusted odd ratios of risk for multiple sclerosis with different combinations of exposure to organic solvents, smoking, infectious mononucleosis (IM) and D-vitamin

\begin{tabular}{|l|c|c|c|c|}
\hline \multicolumn{1}{|c|}{ Parameter } & Cases, $\mathrm{n}(\%)$ & Controls, $\mathrm{n}(\%)$ & OR $(95 \% \mathrm{CI})$ & $p$ \\
\hline Both countries & & & & \\
\hline No Solvents, No Smoking & $356(33,5)$ & $1041(48,7)$ & $1,00($ reference) & \\
\hline Yes Solvents, No Smoking & $38(3,6)$ & $98(4,6)$ & $1,12(0,75-1,67)$ & 0,582 \\
\hline No Solvents, Yes Smoking & $560(52,6)$ & $896(41,9)$ & $1,91(1,63-2,25)$ & 0,000 \\
\hline Yes Solvents, Yes Smoking & $110(10,3)$ & $103(4,8)$ & $3,21(2,36-4,36)$ & 0,000 \\
\hline No Solvents, No IM & $725(72,1)$ & $1689(83,7)$ & $1,00($ reference) & \\
\hline Yes Solvents, No IM & $116(11,5)$ & $172(8,5)$ & $1,49(1,15-1,94)$ & 0,003 \\
\hline No Solvents, Yes IM & $149(14,8)$ & $142(6,0)$ & $2,35(1,83-3,02)$ & 0,000 \\
\hline Yes Solvent, Yes IM & $16(1,6)$ & $16(0,7)$ & $2,17(1,08-4,39)$ & 0,030 \\
\hline No Solvents, High D-vitamin & $432(39,5)$ & $987(46,0)$ & $1,00($ reference) & \\
\hline Yes Solvents, High D-vitamin & $72(6,6)$ & $140(6,5)$ & $1,12(0,82-1,53)$ & 0,486 \\
\hline No Solvents, Low D-vitamin & $511(46,7)$ & $955(44,5)$ & $1,26(1,07-1,47)$ & 0,005 \\
\hline Yes Solvents, Low D-vitamin & $79(7,2)$ & $62(2,9)$ & $2,87(2,02-4,10)$ & 0,000 \\
\hline
\end{tabular}

Table 2

The association between smoking, infectious mononucleosis, D-vitamin level and risk of multiple sclerosis and cases exposed by solvents

\begin{tabular}{|c|c|c|c|c|c|c|}
\hline \multirow{2}{*}{ Data } & \multicolumn{7}{|c|}{ OR (95\% CI) for MS with history of solvents exposure } \\
\cline { 2 - 7 } & No Smoking & Yes Smoking & No IM & Yes IM & High D-vitamin & Low D-vitamin \\
\hline \multirow{2}{*}{$p$} & 1,17 & 1,62 & 1,48 & 1,03 & 1,11 & 2,31 \\
\cline { 2 - 7 } & 0,453 & 0,002 & 0,004 & 0,945 & 0,526 & 0,000 \\
\hline
\end{tabular}


nervous system. Since solvent exposure only seems noxious in smokers, one also must to consider the local inflammation caused by cigarette smoking as a mandatory variable for increasing the risk further.

In the Nordic countries, exposure to solvents is nowadays rather rare, because of hygienic regulations. Our finding is concerning a previous time period, and the participants are to certain extent, older people.
However, in other parts of the world, solvent exposure is still a valid health problem. In addition, our findings can say something about the mechanisms of MS pathogenesis.

Funding. The research was not granted any sponsor support.

Conflict of interests. The authors state there is no any conflict of interests.

\section{References}

1. Bjørnevik K., Riise T., Bostrom I., Casetta I., Cortese M., Granieri E., Holmøy T., Kampman M.T. [et al.]. Negative interaction between smoking and EBV in the risk of multiple sclerosis: The EnvIMS study. Mult. Scler., 2017, vol. 23, no. 7, pp. 1018-1024. DOI: 10.1177/1352458516671028

2. Bjørnevik K., Riise T., Casetta I., Drulovic J., Granieri E., Holmøy T., Kampman M.T., Landtblom A.M. [et al.]. Sun exposure and multiple sclerosis risk in Norway and Italy: The EnvIMS study. Mult. Scler., 2014, vol. 20, no. 8, pp. 1042-1049. DOI: 10.1177/1352458513513968

3. Wesnes K., Riise T., Casetta I., Drulovic J., Granieri E., Holmøy T., Kampman M.T., Landtblom A.M. [et al.]. Body size and the risk of multiple sclerosis in Norway and Italy: The EnvIMS study. Mult. Scler., 2015, vol. 21, no. 4, pp. 388-395. DOI: 10.1177/1352458514546785

4. Olsson T., Barcellos L.F., Alfredsson L. Interactions between genetic, lifestyle and environmental risk factors for multiple sclerosis. Nature, 2017, vol. 13, no. 1, pp. 25-36. DOI: 10.1038/nrneurol.2016.187

5. Flodin U., Soderfeldt B., Noorlind-Brage H., Fredriksson M., Axelson O. Multiple sclerosis, solvents and pets. Arch Neurol., 1988, vol. 45, no. 6, pp. 620-623. DOI: 10.1001/archneur.1988.00520300038015

6. Landtblom A.M., Flodin U., Karlsson M., Palhagen S., Axelson O., Soderfeldt B. Multiple sclerosis and exposure to solvent, ionizing radiation and animals. Scand J. Work Envion Health, 1993, vol. 19 , no. 6, pp. 399-404.

7. Landtblom A.-M., Flodin U., Soderfeldt B., Wolfson C., Axelson O. Organic solvents and multiple sclerosis: a synthesis of the current evidence. Epidemiology, 1996, vol. 7, no. 4, pp. 429-433.

8. Landtblom A.M., Thuomas K.A., Sjoqvist L., Flodin U., Nyland F.H., Soderfeldt B. Hypointensity in T2-weighted images of the basal ganglia in solvent-exposed patients with multiple sclerosis: clinical, MRI and CSF characteristics. Neurol. Sci., 2003, vol. 24, no. 1, pp. 2-9. DOI: 10.1007/s100720300014

9. Landtblom A.-M., Wastenson M., Ahmadi A., Soderkvist P. Multiple sclerosis and exposure to organic solvents, investigated by genetic polymorphisms of the GSTM1 and CYP2D6 enzyme systems. Neurol. Sci., 2003, vol. 24, no. 4, pp. 248-251. DOI: 10.1007/s10072-003-0148-5

10. Mortensen J.T., Bronnum-Hansen H., Rasmussen K. Multiple sclerosis and organic solvents. Epidemiology, 1998, vol. 9, no. 2, pp. 168-171.

11. Napier M.D., Poole C., Statten G.A., Ashley-Koch A., Marrie R.A., Williamson D.M. Heavy metals, organic solvents and multiple sclerosis: an exploratory look at gene-enviroment interactions. Arch. Environ. Occup. Health, 2016, vol. 71, no. 1, pp. 26-34. DOI: 10.1080/19338244.2014.937381

12. Barragan-Martinez C., Speck-Hernandez C.A., Montoya-Ortiz G., Mantilla R.D., Anaya J.-M., Rojas-Villarraga A. Organic solvents as risk factor for autoimmune diseases: A systematic review and meta-analysis. PLoS ONE, vol. 7, no. 12, pp. e51506. DOI: 10.1371/journal.pone.0051506

13. Flodin U., Landtblom A.-M., Axelson O. Multiple sclerosis in nurse anesthetics. Occup. Environ. Med., 2003, vol. 60, no. 1, pp. 66-68. DOI: 10.1136/oem.60.1.66

14. Noseworthy J.H. Trichloretylene poisoning mimicking multiple sclerosis. Le journal Canadien des sciences neurologiques, 1988, vol. 15, no. 1, pp. 87-88.

15. Bove F.J., Ruckart P.Z., Maslia M., Larson T.C. Evaluation of mortality among marines and navy personnel exposed to contaminated drinking water at USMC base Camp Lejeune: a retrospective cohort study. Environmental Health, 2014, vol. 13, 10 p. Available at: http://www.ehjournal.net/content/13/1/10 (03.05.2019) DOI: 10.1186/1476-069X-13-10 
16. Lantblom A.-M., Tondel M., Hjalmarsson P., Flodin U., Axelson O. The risk for multiple sclerosis in female nurse anaesthetisit: a register based study. Occup. Environ. Med., 2006, vol. 63, pp. 387-389. DOI: 10.1136/oem.2005.024604

17. Stenager E., Bronnum-Hansen H., Koch-Henriksen N. Risk of multiple sclerosis in nurse anaesthetists. Multiple sclerosis, 2003, vol. 9, no. 4, pp. 427-428. DOI: 10.1191/1352458503ms941xx

18. Hedstrom A.K., Hillert J., Olsson T., Alfredsson L. Exposure to anaesthetic agents does not affect multiple sclerosis risk. European Journal of Neurology, 2013, vol. 20, no. 5, pp. 735-739. DOI: 10.1111/ene.12098

19. Hedstrom A.K., Hossjer O., Katsoulis M., Kockum I., Olsson T., Alfredsson L. Organic solvents and MS susceptibility, Interaction with MS risk HLA genes. Neurology, 2018, vol. 91, no. 5, pp. e455-e462. DOI: $10.1212 /$ WNL.0000000000005906

20. Magalhaes S., Pugliatti M., Casetta I., Drulovic J., Granieri E., Holmøy T., Kampman M.T., Landtblom A.M. [et al.]. The EnvIMS study: Design and methodology of an international case-control study of environmental risk factors in multiple sclerosis. Neuroepidemiology, 2015, vol. 44, no. 3, pp. 173-181. DOI: $10.1159 / 000381779$

Boström I., Riise T., Björnevik K., Myhr K.-M., Pugliatti M., Wolfson C., Landtblom A.-M. Environmental factors in multiple sclerosis, focusing exposure to organic solvents. Health Risk Analysis, 2019, no. 3, pp. 60-65. DOI: 10.21668/health.risk/2019.3.07.eng

Received: 17.06 .2019

Accepted: 26.07.2019

Published: 30.09.2019 
UDC [325.14+616.97] $(470+571)$

DOI: $10.21668 /$ health.risk/2019.3.08.eng

\title{
ASSESSING POTENTIAL THREAT OF HIV-INFECTION SPREAD IN RUSSIA BY MIGRANTS FROM ASIAN AND AFRICAN COUNTRIES
}

\author{
R.V. Dmitriev ${ }^{1,2}$ \\ ${ }^{1}$ Institute for African Studies of the Russian Academy of Sciences, 30/1 Spiridonovka Str., Moscow, 123001, \\ Russian Federation \\ ${ }^{2}$ Institute of Geography of the Russian Academy of Sciences, 29 Staromonetnyi lane, Moscow, 119017, Russian Federation
}

Recently there has been a growth in number of HIV-infected people among migrants in Russia. Migrants from Asian and African countries are especially dangerous in this respect. An initial stage of HIV epidemic is observed in 13 countries out of total 97 in these two macro-regions (without the Democratic People's Republic of Korea). A generalized stage in the process when HIV spreads beyond common risk groups is detected on the Seychelles and in continental African countries south from Sahara, excluding countries located in the Horn of Africa and several Western African countries. All the other countries in the examined macro-regions are somewhere in-between as regards HIV territorial diffusion as a concentrated stage in the epidemic process is observed there and the disease is predominantly spreading within several risk groups; however, it is highly likely to spread beyond them in the nearest future.

Hierarchical cluster analysis was accomplished as per four aggregated groups of parameters (the current situation in these countries as regards HIV spreading; inflow of migrants from them into Russia; migrant inflow differentiation as per its chronological and chorologic parameters). It allowed assigning all Asian and African countries into four groups as per a size of threat they imposed for Russia concerning HIV-infection spread. The first group included countries with the highest threat (Uzbekistan, Kazakhstan, and Tajikistan). The second group meant a high threat (most North African countries and Middle-East countries, South and Eastern Asian countries, and Nigeria as well). The third group meant an average threat (most African countries located to the south from Sahara and South-Eastern Asian countries as well as some countries excluded from the second group such as Libya, Saudi Arabia, Qatar, Kuwait, Nepal, Bangladesh, Sri Lanka, Laos, Cambodia, and the Philippines). The fourth group included countries that imposed a low threat (all the rest, but there were only few of them, Gambia, Liberia, Niger, Burkina Faso, Gabon, Democratic Republic of Congo, Malawi, Botswana, Eswatini, Lesotho, Eritrea, Djibouti, Oman, Brunei, Butane, and Myanmar). Nevertheless, overall contribution made into HIV spread in Russia by migration is still insignificant. Return migration of people from Russia into a country of their origin is a much greater threat within cross-border HIV diffusion.

Key words: HIV-infection, spread, territorial diffusion, risk groups, cluster analysis, international migration.

HIV-infection was first detected in Russia in 1987 among Russian citizens who had had some sexual contacts with infected foreigners, "mostly, from African countries" [1]. HIV in Russia, just as all over the world, was probably first detected among homosexual men [2]. Obviously it was the case with other former Soviet Republics. Thus, for example, first HIV cases in Tajikistan were registered in 1991 among helicopter pilots who had previously worked in Africa and "got infected due to homosexual contacts with locals" [3].
However, by now the virus has spread beyond HIV risk groups that are usually determined by epidemiologists in many countries all over the world, Russia included. Although migrants are not conventionally assigned into such groups, it was migration that gave way for spatial diffusion of HIV infection between regions and countries in the past (and it still remains a pathway for this infection on multiple territories) $[4,5]$.

Recently in the RF there has been permanent, although uneven, growth in a share of

(C) Dmitriev R.V., 2019

Ruslan V. Dmitriev - Candidate of Geographical Sciences, Senior Researcher (e-mail: dmitrievrv@yandex.ru; tel.: +7 (495) 691-00-61; ORCID: https://orcid.org/0000-0003-4018-9832). 
foreign citizens among people who are "patients with primarily detected antibodies to HIV"; this share went up from $2.9 \%$ in 2011 to $4.3 \%$ in $2015^{1}$. The consequent period was an exception as the parameter dropped to $1.2 \%$ in $2016^{2}$ and to $0.8 \%$ in $2017^{3}$ due to an introduction of a new statistical report form which differed from previously used ones. In Moscow, for example, it resulted in a decrease in "morbidity with HIV-infection" from 60.5 cases in 2015 to 19.5 cases per 100 thousand people in 2016; but an ascending trend still occurred in 2017 as this parameter grew by $23.3 \%$.

Our research goal was to determine potential threats of HIV-infection being spread in Russia by migrants from African and Asian countries.

Data and methods. Some experts state that "there are no grounds to believe that nowadays foreigners exert considerable impacts on HIV spread in Russia" [6]. But at the same time, a growth in relative and absolute number of migrants with detected HIVinfection in Russia (primarily due to greater number of them being examined by medical personnel) has naturally attracted a lot of experts' attention to the issue and resulted in greater number of scientific works on the subject.

Most such works dwell on analyzing regional distribution of migrants with HIV over administrative territories in the RF. Thus, data collected in the Far East [7] and North Caucasian [8] Federal Districts and distributed as per countries of migrants' origin allowed exploring detection of HIV-infection among examined foreign migrants. Research performed on migrants in Saint Petersburg led to a very remarkable conclusion on HIV subtype A1 prevailing in the city; that is, on migration processes being "secluded" between this RF region and Central
Asia [9]. But still, it was shown that in Russia as a whole over the last years there has been a growth in a share of migrants from Ukraine among those with primarily detected HIV infection and a decline in a share of those who came from other CIS states [10]. Experts took data collected in Omsk region and showed [11] that, on one hand, HIV-infection spread was rather low among labor migrants but, on the other hand, "they had a very irresponsible attitude towards medical examinations and tended to practice unsafe sex" and it could result in "deteriorated epidemiologic situation, both in a region where they temporarily resided and in a country of their origin" [12]. Also migrants from former Central Asian USSR republics were usually not so well aware about HIV/AIDS prevention [13] than their counterparts from the Eastern Europe [14].

It is interesting to note that most papers focusing on a role played by migration in HIV infection spread (including abovementioned ones) usually dwell on analyzing the current situation and developing applied aspects of the matter. They are frequently based on quantitative data that are not so easily available for collection, but nevertheless, their predictive potential is rather low. Given that, mathematical and statistical modeling seems to be quite useful for obtaining new knowledge on potential trends in migration of HIV-infected people, current demographic situation as per HIV and ways to regulate it. The present research, in no way being comprehensive and complete, is just a tentative step into this direction.

Our process of data collection and generalization, as regards its contents, consisted of three stages. The first one focused on migration from Asian and African countries to Russia. To assess its scales, we took data provided

\footnotetext{
${ }^{1}$ The situation with HIV-infection in Russia (in 2015). Available at: http://mednet.ru/ru/czentr-monitoringa-tuberkuleza/produkcziya-czentra/analiticheskie-obzory.html (date of visit January 12, 2018).

${ }^{2} \mathrm{HIV}$-infection in Russia in 2016. Available at: http://mednet.ru/images/stories/files/CMT/2016vich.pdf (date of visit December 22, 2017).

${ }^{3}$ The situation with HIV-infection in Russia in 2017. Available at: http://mednet.ru/images/stories/files/miac/2017_vich.pdf (date of visit August 25, 2018).
} 
by the Russian Federal State Statistic Service (Rosstat) $^{4}$ on migration flows from all countries in the world into each RF region over a period from 1993 to 2015 inclusive. Still, there was no consistency in determining this notion, "a migrant", by statistical authorities (and not only them) in the RF over the whole examined period. Given that, we examined four time periods in our analysis as data on migration into $\mathrm{RF}$ available for each of them were comparable. These periods were 1997-2000, 2003-2006, 2007-2010, and 2011-2015. Although certain changes in migration accounting appeared at boundary periods of 2006-2007 and 2010-2011, they had some effects on calculating a number of migrants and not on determining countries of their origin.

So, we obtained ultimate data on intensity of migration flows from Asian and African countries into each RF region and analyzed them. Data on countries from which migrants moved to each RF region in each year of the examined time period gave grounds for preliminary distribution of all the countries into four groups as per scales of their "migration" activity. These four groups were "local" countries (migrants from them moved to less than $1 / 4$ of all the RF regions); "regional" ones (from $1 / 4$ to $1 / 2$ ), "macro-regional" ones (from $1 / 2$ to $3 / 4$ ), and "federal" ones (more than $3 / 4$ ).

The only exception here is Crimea and Sevastopol and they are not considered in our research as they became $\mathrm{RF}$ regions only at the end of the examined time period and statistical data on these two RF regions are scarce; they can't give grounds for any valid conclusions on migration-related "threats". As for foreign countries, we didn't consider some of them (such as South Ossetia or Abkhazia) as they have only recently become independent states.

In this relation the second stage involved work with sources, collection, and systemati- zation of data on HIV spread in Asian and African countries and their analysis for a period from 1993 to 2015. Our primary data sources were two databases that integrated national data on all the world countries, namely UNAIDS, the United Nations AIDS program [15] and the WHO database [16].

To assess rate of HIV spread, we took dynamics of expected number of people in each risk group as our basic parameter (risk groups included sex workers; men who had homosexual contacts; drug addicted people who took injection drugs; transgenders; people in prisons) and HIV prevalence in each of them. UNAIDS and the WHO give recommendations on how to distinguish between different stages in HIV epidemics: the initial stage means HIV has been present in a country for a long time but its prevalence in each risk group stably doesn't exceed 5\%; the concentrated stage means that HIV primarily spreads among people from risk groups and incidence in at least one of them exceeds $5 \%$ while incidence among population in general ${ }^{5}$ doesn't exceed $1 \%$; the generalized stage means HIV spread beyond risk groups and incidence among a country population in general exceeds $1 \%$ [17]. Basing on the said recommendations, we distributed all the Asian and African countries into three groups according to a stage in HIV epidemics that occurred in each of them.

Therefore, if migration from a country into Russia is insignificant in its scales but HIV prevalence in it can be considered the generalized stage in the epidemic process, than, obviously, this country is more dangerous in comparison with another one that "provides" more migrants but the epidemics in it is only at its initial stage.

The third stage was classifying countries as per threats they caused for the RF in general and RF regions in particular as regards HIV spread by migrants. At this stage we analyzed four groups of parameters:

\footnotetext{
${ }^{4}$ The Central Statistical Database of the RF Federal state Statistics Service (Rosstat). Available at: http://cbsd.gks.ru/ (date of visit January 12, 2018).

${ }^{5}$ According to UNAIDS and the WHO recommendations, when concentrated and generalized stages are concerned, it means HIV spreads among pregnant women. Due to lack of such statistical data on all the Asian and African countries over the examined time period, we considered it practicable to take all the population in general as a basis.
} 
1) migration flows from Asian and African countries into Russia, their scales having been identified at the first stage. We primarily paid our attention here to migration flows in 2015 taking into account the current threats. But at the same time migration flows by themselves can' be a "sufficient" parameter for analysis; given that, the overall number of migrants that came to Russia was multiplied by HIV prevalence in countries where migrants came from (\%). The obtained values showed a potential volume of HIV-infected migrants that came to Russia. Data as per countries were summed up, and after that we calculated a share of each country in the overall number of potential HIV-infected migrants. This parameter was given in the first column of the data array which we applied to perform our cluster analysis;

2) it is important to note that the threat of HIV spread in Russia exists not only at the country level, but at the regional one as well. We took a ratio of RF regions where migrants from Asian and African countries came to in 2015 to the overall number of RF regions as our second parameter;

3 ) but at the same time it is obvious that not only the last year out of the examined ones (2015) makes its contribution into occurring threats of HIV spread in the country. Probably, migrants from certain countries come to Russia persistently and every year, and as for other countries, it could be a single migration inflow in 2015. In order to level off the effect produced by the last year, we calculated a ratio of non-zero years for each country as per a number of migrants that came to Russia from it to the overall number of the examined years over the time periods which we had spotted out at the first stage, namely 1997-2000, 2003-2006, 2007-2010, and 2011-2016. This was the third parameter applied within the cluster analysis;

4) threats caused by each country are obviously determined not only by a share of HIV-infected people among its population. We determined a ratio between a number of those risk groups with more than $5 \%$ of people included into them being infected and the overall number of risks groups according to stages in epidemics development in each country. This was our fourth and final parameter.

We performed hierarchical cluster analysis as per Ward's method and four abovementioned parameters with SPSS Statistics 17.0 software; it allowed us to distribute 98 examined Asian and African countries into four groups as per a potential threat they caused for Russia in terms of HIV-infection spread. The threat could be extremely high, high, average, and low. The only exception was The Democratic People's Republic of Korea as there were no necessary data available for that country.

Results and discussion. We analyzed HIV spread among risk groups in Asian and African countries; our analysis revealed that at least one risk group existed in 84 out of 97 countries where more than $5 \%$ of its representatives were infected. It means that the initial stage in HIV epidemics is registered only in each eighth country in these two macro-regions. It is only natural that such countries are predominantly Muslim states in the Middle East and North Africa taking into account an existing inverse dependence between a share of Muslims in a country and HIV spread among population [18]. On the other hand, an effect produced by only one factor related to a religion can't provide a comprehensive explanation for HIV spread: thus, Indonesia is a world leader as per Muslim population [19] but this country has the highest ratio of risk groups with more than $5 \%$ of their representatives being $\mathrm{HIV}$-infected to the overall number of risk groups (4 out of 5). Still, the generalized stage in epidemics with HIV spreading beyond risk groups occurs only on the Seychelles and in continental African states south from Sahara excluding states located on the Horn of Africa and several Western African states. All the remaining countries (most of them are non-Muslim Asian countries) are somewhere in between in terms of HIV diffusion: there is the concentrated stage in epidemics and the infection spreads 
predominantly within several risk groups; however, it can spread beyond them in the nearest future.

At the same time, if we take a threat for our country related to HIV being spread by migrants, we can't state it is obvious that it is African states located to the south form Sahara that create the greatest migration inflows into our country. Indeed, recently more than a half of all migrants to Russia have been coming from three countries, namely Uzbekistan, Kazakhstan, and Tajikistan [20]. And only $0.2 \%$ of the relative number of migrants come from Nigeria that takes the leading place as per a number of migrants to Russia among African countries located to the south from Sahara.

We analyzed a potential threat of HIV spread for Russia caused by migrants coming from Asian and African countries; to do that, we multiplied a number of migrants coming to Russia by a share of HIV-infected people in these countries. It allowed us to detect that it was the first multiplier that made the main contribution. Thus, Uzbekistan, Kazakhstan, and Tajikistan could account for $52 \%$ of potentially HIV-infected migrants. At the same time two African countries, Namibia and Zambia, were also among top ten countries as per this parameter.

However, these quantitative values mostly describe the situation that existed in 20112015, and this period is the most significant but not the only one. Obviously, previous years in the examined time period can also make their contribution into the overall picture. Our analysis of those years during which this or that country "sent" migrants to Russia revealed that existing migration flows are extremely stable. Thus, over the examined period migrants from each of 98 Asian and African countries came to Russia at least once (that is, during at least one year). Besides, more than one third of such countries created annual migration flows to Russia, and all post-USSR states were among these countries, as well as most Northern African and Middle East states. And migrants from only 15 states came to Russia rarer that during each second year; these 15 states include Botswana, Eswatini, and the Seychelles which are dangerous in terms of HIV spread.

At the same time, migrants from some countries come to a lot of Russian regions while migrants from other countries come strictly to just several of them; that is, not only migration flows themselves are quite stable (including those with HIV-infected migrants) but also places where they go to. We analyzed distribution of migrants depending on a country of their origin and a region in the RF as a place where they came to stay and it allowed us to distribute all the flows into four groups (federal, macro-regional, regional and local ones). The greatest role in the process belongs to the flows from the first group coming from countries which "send" migrants to more than $3 / 4$ of the RF regions, namely all the post-USSR Asian states, as well as China, India, Turkey, Iran, and some other countries; there is only one African country among them and it is Egypt.

All the Asian and African countries were distributed into four groups as per potential threats for Russia related to HIV-infection spread; the threshold values for each group are given in Table 1:

1) countries that cause the maximum threats: Uzbekistan, Kazakhstan, and Tajikistan are among them;

2) countries that cause high threats: most North African and Middle East countries, South and East Asian countries, as well as Nigeria;

3) countries that cause average threats: most African countries located to the south from Sahara, Southeast Asian countries, as well as "exceptions" from the second group Libya, Saudi Arabia, Qatar, Kuwait, Nepal, Bangladesh, Sri-Lanka, Laos, Cambodia, and the Philippines;

4) countries that cause low threats: all the remaining countries but there are very few of them; this group includes Gambia, Liberia, Niger, Burkina Faso, Gabon, Congo, Malawi, Botswana, Eswatini, Lesotho, Eritrea, Djibouti, Oman, Brunei, Bhutan, and Myanmar. 
Threshold values of the examined parameters for Asian and African countries distributed into four groups as per threats for Russia caused by HIV-infection spread by migrants

\begin{tabular}{|l|c|c|c|c|}
\hline $\begin{array}{c}\text { Groups as } \\
\text { per a level } \\
\text { of threat }\end{array}$ & $\begin{array}{c}\text { A share of each } \\
\text { country in the } \\
\text { overall quantity of } \\
\text { potential HIV- } \\
\text { infected migrants } \\
\text { from all countries } \\
\text { to the RF }\end{array}$ & $\begin{array}{c}\text { A ratio of a number of } \\
\text { RF regions to which } \\
\text { migrants from each } \\
\text { country in a group came } \\
\text { to in 2015 to the overall } \\
\text { number of regions in } \\
\text { the RF }\end{array}$ & $\begin{array}{c}\text { A ratio of years that were } \\
\text { non-zero in terms of mi- } \\
\text { grants during which each } \\
\text { country from a group "sent" } \\
\text { migrants to the RF to the } \\
\text { overall number of years in } \\
\text { the examined time period }\end{array}$ & $\begin{array}{c}\text { A ratio of a number of } \\
\text { risk groups as per HIV } \\
\text { with more than 5\% of } \\
\text { their representatives } \\
\text { being HIV-infected to } \\
\text { the overall number of } \\
\text { risk groups }\end{array}$ \\
\hline $\begin{array}{l}\text { extremely } \\
\text { high }\end{array}$ & $0.142-0.206$ & 1.000 & 1.000 & 0.200 \\
\hline high & $0.000-0.096$ & $0.617-1.000$ & $0.938-1.000$ & $0.000-0.600$ \\
\hline average & $0.000-0.034$ & $0.074-0.519$ & $0.625-1.000$ & $0.000-0.800$ \\
\hline low & $0.000-0.015$ & $0.012-0.222$ & $0.063-0.563$ & $0.000-0.600$ \\
\hline
\end{tabular}

Conclusion. Our analysis allowed us to establish a contribution made by each of four quantitative parameters into a HIV-related threat caused by migration for Russia: the current situation with the infection spread in Asian and African countries, scales of overall migration flows from these countries to Russia as well as their differentiation as per their chronological features (over each year in an examined time period) and chorologic ones (migration to each of the RF regions). As we can see from Table 1, the greatest contribution is made exactly by the first component as Uzbekistan, Kazakhstan and Tajikistan that "send" the greatest quantities of migrants to Russia are included into a group that causes the maximum threat.

Similar contributions into the overall threat are made by a number of RF regions that accept potentially HIV-infected migrants from Asian and African countries and regularity of such directions in migration flows (the latter parameter here makes a bit higher contribution though). Finally, the smallest contribution is made by a number of risk groups with more than $5 \%$ of their representatives being HIV-infected in countries that "send" migrants to the RF. But still, effects produced by each component in the overall threat can grow stronger or, on the contrary, weaker. Thus, for example, a migration flow from Armenia has been almost similar to that from Tajikistan, but nevertheless, this Caucasian state is among countries that cause high, and not extremely high, threats; it is probably due to less significant HIV spread in it. On the other hand, Nigeria is more dangerous for Russia than the SAR where HIV is more widely spread. It is obviously due to much more considerable migration flows to the RF from this African country which has the greatest population in Africa.

So, if we consider two abstract countries, the former with the greater number of migrants coming form it to Russia but lower HIV incidence, and the latter, on the contrary, with smaller number of migrants bur high HIV incidence, we can state that the former will cause higher threat of HIV spread by migrants. Therefore, in spite of much more significant HIV spread in African countries located to the south from Sahara in comparison with Asian and Northern African countries, it is the latter states that create much more significant threats for Russia in terms of HIV spread by migrants. Nigeria is the only African country located to the south from Sahara that is similar to those states as per this parameter.

Funding. The research has been accomplished at the Institute for African Studies of the RAS and supported by the Russian Science Foundation within the project No. 17-78-10166 "Migration from Asia and Africa as a factor in the spread of HIV/AIDS in Russia: current status, regulation mechanisms, prospects for development".

Conflict of interests. The author declares there is no any conflict of interests. 


\section{References}

1. Borodkina O.I. Sotsial'nyi kontekst epidemii VICh/SPIDa v Rossii [A social context for HIV/AIDS epidemic in Russia]. Zhurnal issledovanii sotsial noi politiki, 2008, vol. 6, no. 2, pp. 151-176 (in Russian).

2. Denissov B.P., Sakevitch V.I. Dynamics of AIDs'/HIV epidemics. Sotsiologicheskie issledovaniya, 2004, no. 1, pp. 151-176 (in Russian).

3. Ruziyev M.M. HIV Epidemiology in the Republic of Tajikistan. VICh-infektsiya i immunosupressii, 2016, vol. 8, no. 4, pp. 55-59 (in Russian). DOI: 10.22328/2077-9828-2016-8-4-55-59

4. Agadjanian V., Zotova N. Structure, Culture, and HIV/STI Vulnerabilities among Migrant Women in Russia. Immigration and Health (Advances in Medical Sociology), 2019, vol. 19, pp. 47-67. DOI: $10.1108 / \mathrm{S} 1057-629020190000019003$

5. Tsapenko I.P., Sautkina V.A. Global migrations and health economics. Terra Economicus, 2018, vol. 16, no. 1, pp. 84-100 (in Russian). DOI: 10.23683/2073-6606-2018-16-1-84-100

6. Pokrovsky V., Ladnaia N., Pokrovskaya A. HIV/AIDS reduces the number of Russians and their life expectancy. Demograficheskoe obozrenie, 2017, vol. 4, no. 1, pp.65-82 (in Russian). DOI:10.17323/demreview.v4i1.6988

7. Korita T.V., Ivanov A.N., Balahontseva L.A., Trotsenko O.E. The role of immigrants in the development of HIV epidemic in the far eastern federal district. Dal'nevostochnyi zhurnal infektsionnoi patologii, 2012, no. 21, pp. 74-83, (in Russian).

8. Dmitriev R.V. Transformatsiyasotsial'no-ekologicheskoisituatsiipoVICh-infektsii v SeveroKavkazskom federal'nom okruge pod vliyaniem vneshnei migratsii [Transformation of a social and ecological situation as regards HIV-infection in the North Caucasian Federal District caused by external migration]. Yug Rossii: ekologiya, razvitie, 2019, vol. 14, no. 3, pp. 115-123 (in Russian). DOI: 10.18470/19921098-2019-3-115-123

9. Belyakov N.A., Vinogradova T.N., Panteleyeva O.V., Kosenko Yu.Yu., Tikhonova Ye.M., Logvinenko A.A., Dement'yeva N.Ye., Rakhmanova A.G. Investigation into HIV prevalence among foreign migrants in Saint-Petersburg, russia. VICh-infektsiya i immunosupressii, 2014, vol. 6, no. 4, pp. 7-16 (in Russian). DOI: 10.22328/2077-9828-2014-6-4-7-16

10. Mikhaylova Yu.V., Nechaeva O.B., Shikina I.B., Sorokin V.N. Impact of migration factor on TB and HIV epidemic situation in Russia. Sotsial'nye aspekty zdorov'ya naseleniya, 2018, vol. 62, no. 4, pp. 1-18 (in Russian). DOI: 10.21045/2071-5021-2018-62-4-4

11. Kalacheva G.A., Rubina Y.L., Rudakov N.V., Buslova L.E. Epidemiologicheskie aspekty VICh-infektsii sredi trudovykh migrantov [Epidemiologic aspects of HIV-infection among labor migrants]. Zhurnal infektologii, 2017, vol. 9, no. 4, pp. 105 (in Russian).

12. Kalacheva G.A., Rubina Y.L., Rudakov N.V., Buslova L.E. Migration workers and HIV in Siberia. VICh-infektsiy i immunosupressii, 2018, vol. 10, no. 3, pp. 102-107 (in Russian).DOI: 10.22328/2077-9828-2018-10-3-102-107

13. Rafiev H.K., Latipov A.L., Rafieva Z.H. Epidemiological situation on AIDs between migrants to Tajikistan. Vestnik Avitsenny, 2008, vol. 37, no. 4, pp. 78-81 (in Russian).

14. Amirkhanian Yu.A., Kuznetsova A.V., Kelly J.A., Di Franceisco W.J., Musatov V.B., Avsukevich N.A., Chaika N.A., McAuliffe T.L. Male Labor Migrants in Russia: HIV Risk Behavior Levels, Contextual Factors, and Prevention Needs. Journal of Immigrant and Minority Health, 2011, vol. 13, no. 5, pp. 919-928. DOI: 10.1007/s10903-010-9376-y

15. AIDSinfo. UNAIDS. Available at: http://aidsinfo.unaids.org/ (12.01.2018).

16. HIV/AIDS. World Health Organization. Available at: http://www.who.int/hiv/data/en/ (28.01.2018).

17. Brookmeyer R. Measuring the HIV/AIDS Epidemic: Approaches and Challenges.Epidemiologic Reviews, 2010, vol. 32, no. 1, pp. 26-37. DOI: https://doi.org/10.1093/epirev/mxq002

18. Speakman S. Comparing the Impact of Religious Discourse on HIV/AIDS in Islam and Christianity in Africa. Vanderbilt Undergraduate Research Journal, 2012, no. 8, pp. 1-7. DOI: https://doi.org/10.15695/vurj.v8i0.3490 
19. Gorokhov S.A., Dmitriev R.V. The components of the Christian population dynamics at the beginning of the 21st century: world, region, country. Vestnik Tomskogo gosudarstvennogo universiteta, 2017, no. 418, pp. 85-90 (in Russian). DOI: 10.17223/15617793/418/11

20. Arkhangelsky V.N., Danilova I.A., Dmitriev R.V., Khasanova R.R. Prospects of the demographic development of Russia until the MID-century. Narodonaselenie, 2017, vol. 77, no. 3, pp. 24-36 (in Russian). DOI: 10.26653/1561-7785-2017-3-2

Dmitriev R.V. Assessing potential threat of hiv-infection spread in Russia by migrants from asian and african countries. Health Risk Analysis, 2019, no. 3, pp. 66-73. DOI: 10.21668/health.risk/2019.3.08.eng

Received: 04.04.2019

Accepted: 08.08.2019

Published: 30.09.2019 
UDC 616-036.2

DOI: 10.21668/health.risk/2019.3.09.eng

GEOINFORMATION TECHNOLOGIES FOR ASSESSING EPIZOOTOLOGIC AND EPIDEMIOLOGIC SITUATION WITH ANTHRAX

\author{
E.G. Simonova ${ }^{1,2}$, A.A. Shabeikin ${ }^{3}$, S.R. Raichich ${ }^{1}$, M.N. Loktionova ${ }^{1,2}$, S.A. Saburova ${ }^{1}$, \\ M.A. Patyashina ${ }^{4}$, V.I. Ladnyi ${ }^{1}$, A.M. Gulyukin ${ }^{3}$ \\ ${ }^{1}$ Central Research Institute of Epidemiology, 3A Novogireevskaya Str., Moscow, 111123, Russian Federation \\ ${ }^{2}$ I.M. Sechenov First Moscow State Medical University, bld. 2, 8 Trubetskaya Str., Moscow, 119991, Russian \\ Federation \\ ${ }^{3}$ Ya. R. Kovalenko and K.I. Skryabin's Russian Scientific and Research Institute for Experimental Veterinary, \\ 1 bld., 24 Ryazanskii Ave., Moscow, 109428, Russian Federation \\ ${ }^{4}$ Federal Service for Surveillance over Consumer Rights Protection and Human Wellbeing, in the Republic of \\ Tatarstan, 30 Bol`shaya Krasnaya Str., Kazan`, 420111, Russian Federation
}

The article dwells on opportunities granted by application of geoinformation technologies in surveillance over anthrax, an infection that still remains rather dangerous. It was shown that, in spite of a decrease in incidence with anthrax among animals and people, risks persist on the RF territory; these risks are caused by residual activity in soil foci. A geoinformation system was applied to determine that at present areas where anthrax can be detected are predominantly located in forest-steppe zones, steppe zones, dry steppe zones, and Caucasian-Crimean mountain regions. $82 \%$ of all the outbreaks detected in the $21^{\text {st }}$ century occurred in these geographic zones. Unfavorable situation with anthrax seems to be clearly bound to territories with prevailing leached black earth, common black earth, mountain black earth, and mountain cinnamonic soil. Over the last years most anthrax outbreaks have occurred on these territories. All these territories were shown to have warm climate, with predominant stockbreeding in agriculture, as well as great numbers of cattle in private households; these cattle grazed freely on territories of natural foci with anthrax, and a lot of household work was handled manually. Territories that took leading places among unfavorable ones usually had a lot of households with cattle that nowadays remains a basic source of epidemiologic risk. We chose Tatarstan as a model region to show opportunities offered by a geoinformation system for improving epidemiologic surveillance over anthrax in relation to risk assessment. This territory was chosen due to high epizootologic activity and sporadic incidence among population detected there. We revealed risk territories in the region, determined basic reasons for unfavorable situation with anthrax as well as factors that made this situation even more complicated.

Key words: anthrax, soil focus, stationary unfavorable point, anthrax disposal, risk assessment, geoinformation system.

Issues related to elimination of anthrax ting infected due to sporadic morbidity are rather complicated but nonetheless further among animals seems to be quite achievable decrease in population morbidity with the in the Russian Federation [1-3]. It can be disease and even putting a stop to people get- done due to long-term experience accumu-

(C) Simonova E.G., Shabeikin A.A., Raichich S.R., Loktionova M.N., Saburova S.A., Patyashina M.A., Ladnyi V.I., Gulyukin A.M., 2019

Elena G. Simonova - Doctor of Medical Sciences, Professor at the Epidemiology Department, Leading researcher at the Laboratory for Epidemiology of Natural Foci Infections (e-mail: simonova_e_g@mail.ru; tel.: +7 (495) 602-12-75; ORCID: https://orcid.org/0000-0001-7179-9890).

Aleksandr A. Shabeikin - Candidate of Veterinary Sciences, leading researcher at the Epizootology Laboratory (e-mail: viev@mail.ru; tel.: +7 (925) 504-64-87; ORCID: https://orcid.org/0000-0003-3413-8131).

Stefan R. Raichich - junior researcher at the Laboratory for Epidemiology of Natural Foci Infections (e-mail: anthraxcrie@gmail.com; tel.: +7 (495) 672-11-73; ORCID: https://orcid.org/0000-0002-7734-7382).

Marina N. Loktionova - Candidate of Medical Sciences, Associate professor at the Epidemiology Department, researcher at the Laboratory for Epidemiology of Natural Foci Infections (e-mail: anthraxcrie@gmail.com; tel.: +7 (903) 618-37-96; ORCID: https://orcid.org/0000-0003-1332-519X).

Svetlana A. Saburova - Candidate of Medical Sciences, researcher at the Laboratory for Epidemiology of Natural Foci Infections (e-mail: anthraxcrie@gmail.com; tel.: +7 (495) 672-11-73; ORCID: https://orcid.org/0000-0002-9332-0526).

Marina A. Patyashina - Doctor of Medical Sciences, Supervisor (e-mail: rpn.rt@tatar.ru; tel.: +7 (843) 238-98-54; ORCID: https://orcid.org/0000-0002-6302-3993).

Viktor I. Ladnyi - researcher at the Laboratory for Epidemiology of Natural Foci Infections (e-mail: anthraxcrie@gmail.com; tel.: +7 (495)672-11-73; ORCID: https://orcid.org/0000-0001-7525-8127).

Aleksei M. Gulyukin - Candidate of Biological Sciences, Director (e-mail: admin@viev.r; tel.: +7 (495) 970-03-67; ORCID: https://orcid.org/0000-0003-2160-4770). 
lated in managing epidemiologic processes with its key focus being on epizootologic and epidemiologic surveillance. Given that, experts have made a lot of efforts trying to improve organizational and, above all, conceptual and methodological components in surveillance over anthrax [4].

Spread of information technologies and development of geoinformation systems (GIS) provide new tools for analyzing and assessing epizootologic and epidemiologic risks. GIS technologies here are considered an instrument for pre-epidemic diagnostics and prediction of how a situation may develop in future $[5,6]$. They allow accumulating significant data arrays on risk factors, performing conjugate multi-factor analysis with revealing indicators of unfavorable epizootologic and epidemiologic situations, and determining trends and forecasts of their future development [7]. Anthrax outbreak that occurred on Yamal Peninsula in 2016 proved it was necessary to monitor over natural and social risk factors that could cause the disease $[8,9]$. Such monitoring should be oriented at anthrax soil foci, stationary unfavorable points (SUPs) that are located within them [10], and anthrax disposals where dead animals were buried [11] with their hazards being determined via GIS.

So, at present it is vital to develop and implement GIS technologies into surveillance over anthrax as it helps to provide sanitaryepidemiologic welfare of the population in the country.

Our research goal was to assess the existing epizootologic and epidemiologic situation as regards anthrax and risks related to its probable worsening on the RF territory applying GIS technologies.

Data and methods. We took official statistic data collected in 2001-2018 (The federal statistics reports, Form No. 2 "Data on infectious and parasitic diseases"; Forms No. 23-06 and 23-09 "Data on outbreaks of infectious diseases"; statistic data on morbidity with anthrax among animals in the Russian Federation given in forms No 1-VET and 1-VET A); information and analytical and archives materials; data taken from the Register of anthraxrelated stationary unfavorable points (SUPs) in the Russian Federation [12] with the latest entries made in 2017 (3,5631 SUPs), the freshest data from the regional register of Tatarstan (1,205 SUPs), and also data on 806 anthrax disposals (ADs) existing in this region.

To assess existing risks, we took data provided by the Federal State Statistics Service on the structure and numbers of agricultural animals that were epidemiologically significant ${ }^{1}$; we also took data from other available sources that could help us describe social and economic development of the examined territories.

Spatial and time dynamics of the situation with anthrax in the RF as well as any possibility it could get worse due to risk factors was assessed on the example of Tatarstan in GIS applications built on ArcGIS [www.esri.com] and QGIS [www.Qgis.org] platforms. To do that, we created digital maps that showed SUPs localization and activity as well as ADs locations. There were several stages in creating these subject maps; first, we created a cartographic database on registered anthrax outbreaks and SUPs becoming active; then we gave geocodes to SUPs and ADs and implemented cartographic layers into a developed GIS-project. These layers showed binding to settlements; administrative division; natural and agricultural zones existing on a territory; soil, landscape, and hydrographic conditions. Our task was to examine peculiarities related to territorial distribution of SUPs and ADs in Tatarstan; to do that, we built a digital map in a GIS-application and applied gradient coloring to show administrative districts depending on a number of anthrax outbreaks in each of them; we also created "a heat map" and applied gradient color-

\footnotetext{
${ }^{1}$ Basic results of agriculture in Russia in 2017: Bulletin. The Federal State Statistics Service: official web-site, 2018 Available at: http://www.gks.ru/wps/wcm/connect/rosstat_main/rosstat/ru/statistics/publications/catalog/doc_1140096652250 (date of visit March 03, 2019).
} 
ing to show the greatest density of spatial objects location on it.

Results and discussion. Intensity and geography of anthrax in the RF has changed considerably over almost a hundred-year observation period. Maximum number of registered anthrax outbreaks among animals occurred in the middle of the $20^{\text {th }}$ century and reached 2,273 by 1950 . Anthrax outbreaks among animals resulted in people being infected with the disease. Back then there were more than 500 registered anthrax cases among population in the Russian Soviet Federative Socialist Republic [13].

A set of activities was implemented; they were aimed at breaking an epizootologic chain (carcasses of dead animals were obligatorily burnt and there was large-scale regular vaccination of agricultural animals). It led to a steady decrease in intensity of anthrax epizooties. Number of outbreaks went down exponentially with approximately a three-time decrease occurring each ten years $[14,15]$.

Starting from 2001 on average 7 epizootic foci were registered annually in the RF; over the last decade an average annual number of anthrax outbreaks has been equal to 3.6. In 2001-2018 there were 2,926 anthrax cases registered among animals. Simultaneously with a decrease in morbidity among animals there was a drop in number of the RF regions where anthrax outbreaks were detected. Thus, in 50ties last century anthrax was detected in 79 regions in the country, but as for the last decades, it was detected in only 22 regions (Figures 1 and 2).

Most active SUPs were located in the Central Federal District (22.2\%), Southern Federal District (20.7\%), North-Caucasian Federal District (20.0\%), and Privolzhskiy Federal District (19.2\%).

In 2001-2018 there were 171 anthrax cases registered among people. We should note that recently ratio of morbidity among people to that among animals has changed. Thus, in the $20^{\text {th }}$ century epizooties among animals didn't necessarily resulted in people getting infected; at present any registered epizooty leads to infection spread among popula- tion. Large epidemic foci that occurred during anthrax epizooties were detected in 2004 (Orenburg, 10 people), 2008 (Buryatia and Bashkortostan, 8 and 11 people respectively), 2010 (Omsk region and Dagestan, 6 people in each region), 2012 (Altai region, 6), 2016 (Yamal-Nenets Autonomous Area, 36 people). All the above-mentioned deteriorated situations were caused by recurrent activities in soil foci including those located close to old anthrax disposals (Altai region, Buryatia, and Bashkortostan) as well as close to places where a lot of animals had died prior to epidemics outbreaks (Yamal-Nenets Autonomous Area).

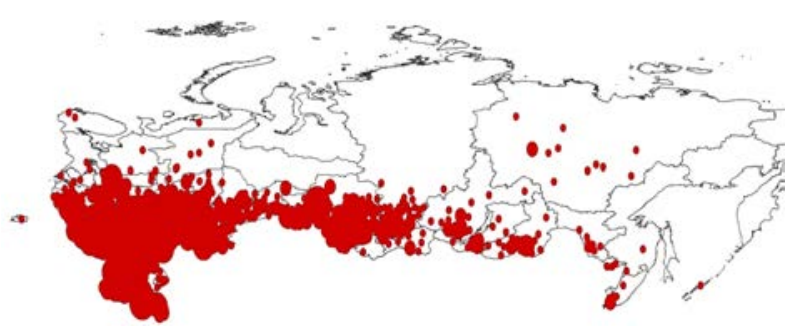

Figure 1. A map showing territorial distribution of epizootic anthrax foci in the Russian Federation in 1950-1959

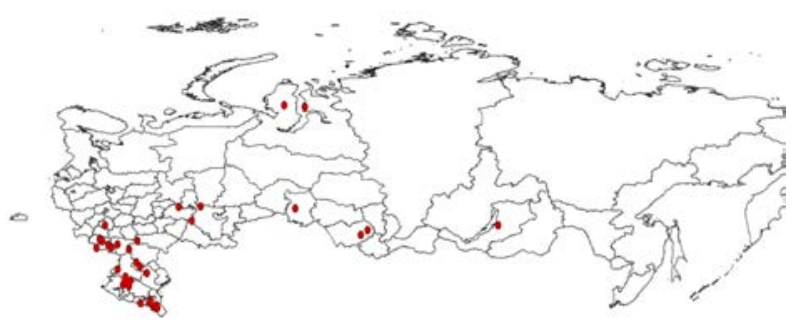

Figure 2. A map showing territorial distribution of epizootic anthrax foci in the Russian Federation in 2008-2017

Conjugated analysis of morbidity among people and animals revealed that sometimes anthrax cases among animals were detected only after anthrax had been diagnosed in people. Thus, our analysis revealed that only 46 out of total 55 epidemic foci were related to morbidity among animals. Any relation with morbidity among animals wasn't detected for 9 epidemic foci but still there were some indications that infected people had contacted either animals or animal raw materials. On one hand, it can be due to negligent surveillance over morbidity among animals; on the other 
hand, it can be caused by social and economic risks that led to changes in ways and factors of contagion.

To sum up, a contemporary situation with anthrax in Russia, as well as all over the world, can still deteriorate as there are risks that can cause it; such risks may result not only in epizooties but also in morbidity among population exposed to existing risk factors $[16,17]$. An anthrax outbreak that occurred in 2016 on Yamal Peninsula is a good example; such outbreaks prove it is necessary to perform constant complex risk assessment. Recently GIS technologies have been widely and successfully used to solve this complicated scientific and practical task as they allow determining existing trends related to epizootic activity and tracking dynamics of changes in risk factors; consequently, such technologies enable predicting possible epizootic and epidemic complications [18].

GIS technologies allow determining territories where epizootologic and epidemiologic risks occur with geographic zones being ranked as per level of risks existing there and with identifying most significant risk factors. We performed spatial analysis of epizootic outbreaks localization and revealed that over the last 15 years unfavorable situations with anthrax have been clearly bound to zones with prevailing black soils. $58.1 \%$ anthrax outbreaks were registered exactly on such territories (Figure 3).

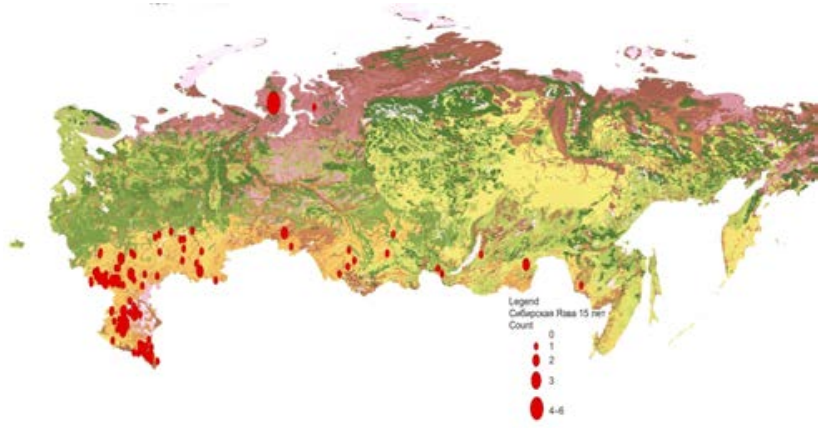

Figure 3. Anthrax outbreaks registered in 2003-2018 given on the map of Russia that shows types of soils

We analyzed how anthrax outbreaks were distributed over natural and agricultural zones and revealed that a contemporary anthrax area was predominantly located in for- est-steppe, steppe, dry-steppe, and CaucasianCrimean mountain zones. In $21^{\text {st }}$ century $82 \%$ of all the registered anthrax outbreaks occurred in these four natural zones. All these territories have warm climate, animal breeding is well-developed there, and there are great numbers of cattle in private households. As is known, specific epidemiologic significance now belongs to cattle and small cattle bred in private and farmer households located on territories where the situation with anthrax is unfavorable.

As per data provided by Rosstat, in 2017 sheep accounted for the greatest specific share among agricultural animals in Russia $(36.9 \%)$; pigs and cattle had the second and the third place with $34.9 \%$ and $28.2 \%$ respectively. Cattle were mostly bred by agricultural organizations $(44.2 \%)$ and private households (42.4\%); pigs were predominantly bred by agricultural organizations $(85.6 \%)$; sheep were bred by private households $(46.5 \%)$ and farmers $(37.0 \%)$.

Cattle are mostly bred in Privolzhskiy Federal District (27.6\%), Siberian Federal District $(21.9 \%)$, Central Federal District (15.6\%), Southern Federal District (12.5\%), and North Caucasian Federal District (11.8\%). The greatest cattle numbers are bred in Bashkortostan, Tatarstan, Dagestan, Altai region, Krasnodar region, Rostov region, and Orenburg region; all these territories are stationary unfavorable as per anthrax. Also significant numbers of cattle are bred In Novosibirsk region, Voronezh region, Bryansk region, Saratov region, Zabaikalye region, Krasnoyarsk region, and Kalmykia; there are SUPs in all these regions.

The greatest numbers of small cattle are bred in North Caucasian Federal District (40.0\%), Southern Federal District (26.4\%), Siberian Federal District (16.1\%), and Privolzhskiy Federal District (11.0\%). Leading regions in this respect are Dagestan, Kalmykia, Tyva, Karachai-Cherkess, Stavropol region, Astrakhan region, Rostov region, and Volgograd region. More than 400 thousand small cattle are bred in Bashkortostan, Altai region, Transbaikalia, and Saratov region, that is, on territories with elevated anthrax risks. 
Table 1

Active anthrax-related stationary unfavorable points depending on soil types, $\%$

\begin{tabular}{|l|c|c|c|c|}
\hline \multirow{2}{*}{ Soil types } & \multicolumn{4}{|c|}{ Periods during which stationary } \\
\cline { 2 - 5 } & $\begin{array}{c}1929- \\
1953\end{array}$ & $\begin{array}{c}1954- \\
1978\end{array}$ & $\begin{array}{c}1979- \\
2002\end{array}$ & $\begin{array}{c}2003- \\
2017\end{array}$ \\
\hline Sod-podzol & 8.3 & 3.9 & 5.4 & 1.4 \\
\hline Gray forest & 12.3 & 4.8 & 7 & 4.1 \\
\hline $\begin{array}{l}\text { Leached- } \\
\text { black }\end{array}$ & 14.8 & 14.8 & $25.4^{*}$ & $24.3^{*}$ \\
\hline $\begin{array}{l}\text { Typical } \\
\text { black }\end{array}$ & 1.1 & 3.1 & 9.2 & 8.1 \\
\hline $\begin{array}{l}\text { Ordinary } \\
\text { black }\end{array}$ & 6.5 & 7.9 & $17.1^{*}$ & $24.3^{*}$ \\
\hline $\begin{array}{l}\text { Southern } \\
\text { black }\end{array}$ & 2.6 & 3 & $9.2^{*}$ & 1.4 \\
\hline Chestnut & 0.2 & 0.4 & 2 & 2.7 \\
\hline $\begin{array}{l}\text { Chestnut- } \\
\text { Solonetzic }\end{array}$ & 0.9 & 1 & 3.3 & 5.4 \\
\hline Others & 63.3 & 71.1 & 31.4 & 38.3 \\
\hline
\end{tabular}

${ }^{*} \mathrm{p}<0.001$ against $1929-1953$ and $1954-1978$.

If we compare boundaries of nosoareas that existed in different time periods, we can see that starting from the end of the last century territories with leached-black and ordinary black soils have become much more significant from epizootologic point of view whereas territories with gray forest soils and sod-podzol soils have become considerably less significant (Table 1).

Simultaneously, a share of zones located in mountains has grown from $2 \%$ to $16.3 \%$.
Given complicated landscapes in mountains and prevailing combinations of several different soil types there, it was difficult to exactly determine a type of soil in a zone where a SUP occurred; most probably, animals caught the disease on pastures that were predominantly located in areas with mountain black soils and mountain cinnamonic soils (Dagestan and Chechnya).

We analyzed spatial distribution of SUPs and ADs in a specific region with a GIS application on larger-scaled maps and it allowed us to examine risks in greater detail.

We chose Tatarstan as a model region for demonstrating how GIS technologies could be applied to improve epidemiologic surveillance over anthrax and to assess related risks more precisely. This region is permanently considered unfavorable from epizootologic points of view. Over the last 100 years 2,035 anthrax outbreaks have been registered in Tatarstan in 1,205 SUPs located there (3.4\% out of total anthrax-related SUPs in the Russian Federation, the $7^{\text {th }}$ rank place in the country). At present the situation is unfavorable in $37.5 \%$ settlements located in Tatarstan (the $27^{\text {th }}$ rank place in the RF), and SUPs density amounts to 17.7 per 1,000 square $\mathrm{km}$ (the $14^{\text {th }}$ rank place in the RF)

In 2001-2018 epizootic activity was high in Tatarstan and occurred in 8 SUPs located in 7 municipal districts; 3 people got infected with anthrax and fell ill (Table 2).

Table 2

Active anthrax-related stationary unfavorable points in Tatarstan

\begin{tabular}{|l|c|c|c|c|c|c|c|}
\hline \multirow{2}{*}{ District } & Settlement & \multicolumn{4}{c|}{ Active SUP } & \multicolumn{2}{c|}{ Morbidity } \\
\cline { 3 - 9 } & & $\begin{array}{c}\text { Multiplic- } \\
\text { ity, times }\end{array}$ & $\begin{array}{c}\text { The } \\
\text { 1st year }\end{array}$ & $\begin{array}{c}\text { The last but } \\
\text { one year }\end{array}$ & $\begin{array}{c}\text { The last } \\
\text { year }\end{array}$ & people & animals \\
\hline Tukaevskiy & Terovo village & 1 & & & 2001 & & + \\
\hline Cheremshanskiy & Chyorniy Klyuch village & 2 & 1967 & 1967 & 2001 & & + \\
\hline Myslyumovskiy & Tegermyanlek village & 1 & & & 2002 & & + \\
\hline Sarmanovskiy & Martysh-Tamak village & 1 & & & 2003 & & + \\
\hline Zelenodol'skiy & Kugushevo village & 2 & 1962 & 1962 & 2003 & + & + \\
\hline Bavlinskiy & Isergapovo village & 3 & 1935 & 1953 & 2008 & & + \\
\hline \multirow{2}{*}{ Kukmorsliy } & Knyabash village & 2 & 1937 & 1937 & 2014 & + & + \\
\cline { 2 - 9 } & Lyuga village & 6 & 1942 & 1951 & 2014 & + & + \\
\hline
\end{tabular}


Accomplished SUPs mapping revealed that in the $21^{\text {st }}$ century the most epizootically unfavorable situation occurred in the northern and central parts of the region (Figure 4). Baltasinskiy, Elabuga, Mendeleevskiy, Al'metyevskiy, Chistopolskiy, Atninskiy, and Kukmorskiy districts as well as Naberezhnye Chelni are the most unfavorable as per SUPs density. Animal breeding is well-developed in all the above-mentioned regions, except from Baltasinksiy district and Naberezhnye Chelni. Agricultural organizations in the region, including farmers, are numerous (there can be more than 100 hundred of them in a district, for example, in Kukmorskiy district); they breed cattle and small cattle as well as pigs and horses; consequently, certain anthrax-related risks may well occur on these territories.

ADs mapping revealed that they occurred in most administrative districts in the republic (Figure 5).

However, spatial analysis didn't reveal their exact binding to SUPs that have become active over the last 20 years. All the anthrax disposals were located 1,000 meters or more away from SUPs. It can be explained via multiple anthrax soil foci that occurred in the past in places where animals died; such places were often located far from boundaries of areas where cattle were buried. At the same time, we can't neglect a possibility that there are spontaneous animal burial places that haven't been registered; such burials can contain carcasses of animals infected with anthrax as those animals died from the disease during mass epizooties that occurred in the $19^{\text {th }}$ and early $20^{\text {th }}$ century.

We analyzed density of risk objects location and revealed that anthrax disposals were predominantly located in districts that were close to boundaries of the region and the maximum density was observed in the northern parts (Figure 6). The results we obtained are naturally in line with SUPs distribution in the republic and correspond to places where anthrax epizooties were registered in the $20^{\text {th }}$ century. Over the last 100 years animal-breeding areas located in the northern parts of the republic suffered most

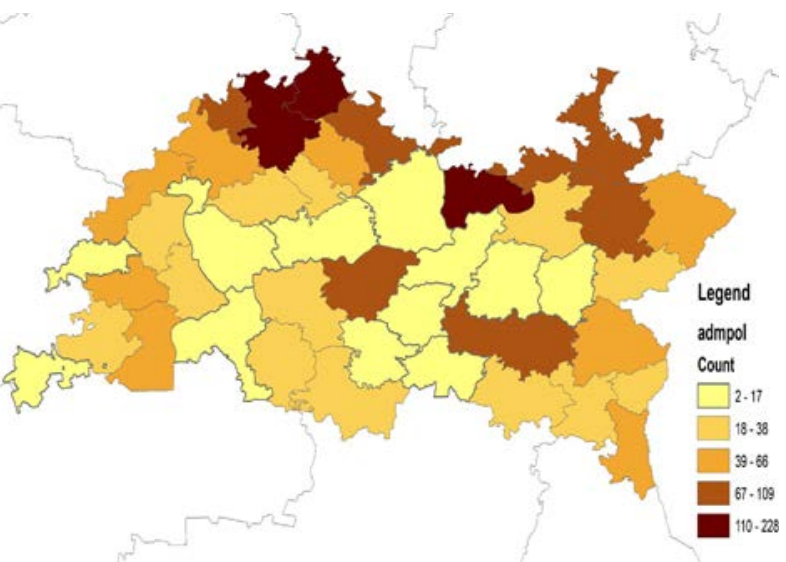

Figure 4. Territorial distribution of anthrax-related stationary unfavorable points registered in Tatarstan

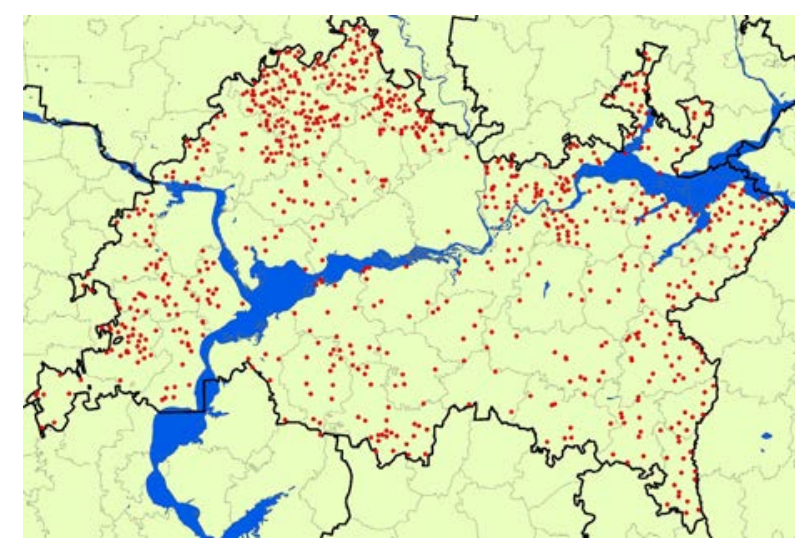

Figure 5. Anthrax disposals located in Tatarstan

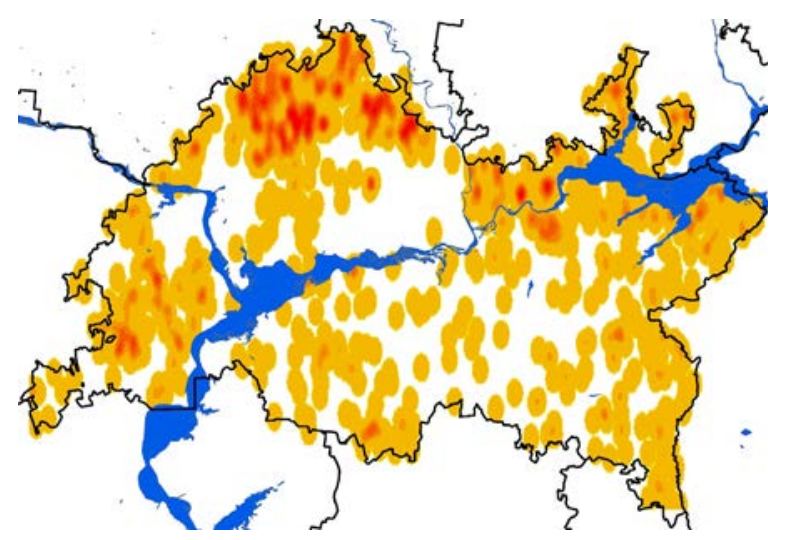

Figure 6. "Heat" map showing density of anthrax disposals in Tatarstan Zones with higher density are given in darker color; red color means the maximum density

from anthrax epizooties (Figure 7), and it should result in them being the most contaminated with B.anthracis spores.

Hiowever, northern areas mostly have gray forest soils with average humus contents, whereas black soils with high humus contents 


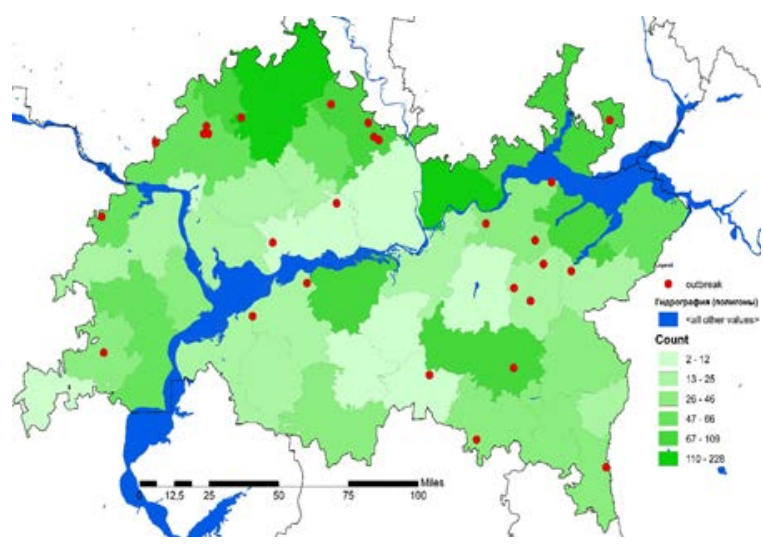

Figure 7. A map showing density of anthrax outbreaks in Tatarstan

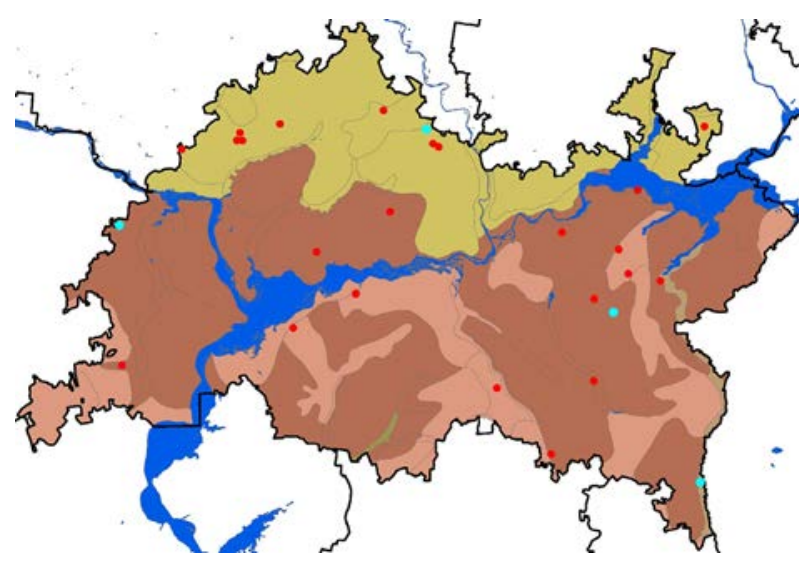

- Anthrax outbreaks from 1988 to 2002 Anthrax outbreaks after 2003

Figure 8. Territorial distribution of anthrax outbreaks in Tatarstan from 1988 to 2018 (combined with soils map)

can be found in central and southern parts of the republic (Figure 8).

Should we stick to a concept that describes formaiton of "incubation" soil zones $[19,20]$, than in Tatarstan we face a situation when initially maximum soil foci occurred in the north of the republic whereas the most stable soil foci should have occurred in the center and in the south of it. The existing epizootic situation is well in line with this hypothesis. Over the last 30 years anthrax outbreaks were divided in approximately even proportions between areas with bleached black soils and gray forest soils, $35 \%$ and $31 \%$ respectively.

Since 2003 there have been 4 anthrax outbreaks registered in 4 administrative districts in Tatarstan located in the north (Kukmorskiy district), west (Zelenodol'skiy dis- trict), east (Sarmanovskiy district), and southeast (Bavlinskiy district) of the republic. Unfavorable situations with anthrax were mostly (in three cases) due to recurrent activities in SUPs located in areas with back soils.

An only exception here is an outbreak that occurred in 2014 in Kukmorskiy district, a territory with high SUPs density and prevailing gray forest soils; there were several settlements involved and 2 people got infected. Epizootology might occur due to recurrent activities in soil foci that resulted in stored forages being contaminated with the infectious agent; it might also occur due to infected cattle being brought to the district from other unfavorable territories.

Conclusions. In the next decades epizootic situation as regards anthrax is going to remain the same as it is now, given the existing procedures for veterinary-sanitary surveillance activities and trends in animal breeding development in the RF. Risks that it may deteriorate are persistent due to recurrent activities in soil foci that have been inactive for a long period of time; expectation period here may amount to 40 and even more years.

As our research has revealed, there is a hazard that new anthrax outbreaks may occur in any SUP should there be any relevant risks; such risks are suitable soils as well as susceptible animals that contact potentially hazardous soils. Given that, at present the greatest epizootologic and epidemiologic risks are related to private agricultural farms and households where cattle and small cattle graze freely and most tasks are man-handled.

Data accumulated in cartographic databases allow accomplishing comprehensive spatial-time analysis of anthrax prevalence on the RF territory. Its results indicate that maximum epizootic and epidemiologic risks still tend to occur on areas with black soils. But still, other soil types, especially gray forest soils and chestnut soils, are still significant form epizootologic point of view in some regions, including Tatarstan.

At present application of GIS technologies in surveillance over anthrax is an integral 
component in epidemic diagnostics as it allows establishing dynamics in soil foci activity, putting forward hypotheses on causes and conditions of epizootic and epidemiologic processes as well as ranking regions in the country as per potential epizootic and epidemiologic risks.

It is necessary to integrate data on stationary unfavorable points and anthrax disposals with cartographic grounds for administrative-territorial division and natural and ag- ricultural zoning basing on GIS applications; it is a significant step in improving risks prediction and providing information support for decision making in the sphere of surveillance and control over anthrax in the Russian Federation.

Funding. The research was not granted any sponsor support.

Conflict of interests. The authors declare there is no any conflict of interests..

\section{References}

1. Cherkasskii B.L. Epidemiologiya i profilaktika sibirskoi yazvy [Anthrax: epidemiology and prevention]. Moscow, Intersen Publ., 2002, 384 p. (in Russian).

2. Onishchenko G.G., Darmov I.V., Vasil'ev N.T., Kirillov I.A., Kikot' S.G., Borisevich S.V., Tumanov A.S., Bakulin M.K. [et al.] Sibirskaya yazva: aktual'nye problem razrabotki i vnedreniya meditsinskikh sredstv zashchity [Anthrax: vital issues related to development and implementation of medical protection]. In: G.G. Onishchenko, I.V. Darmov, S.V. Borisevich eds. 2-nd edition. Sergiev Posad, 2018, 591 p. (in Russian).

3. Makarov V.V. Anthrax in the early 21 st century. Veterinariya, 2017, no. 1, pp. 3-8 (in Russian).

4. Popova A.Yu., Ezhlova E.B., Demina Yu.V., Kulichenko A.N., Ryazanova A.G., Buravtseva N.P., Eremenko E.I., Dyatlov I.A. [et al.]. Ways to improve the epidemiological surveillance and control of anthrax in the Russian Federation. Problemy osobo opasnykh infektsii, 2017, no. 1, pp. 84-88 (in Russian).

5. Clarke K.C., McLafferty S.L., Tempalski B.J. On epidemiology and geographic information systems: a review and discussion of future directions. Emerg. Infect. Dis., 1996, no. 2, pp. 85-92. DOI: $10.3201 /$ eid0202.960202

6. Curtis A.C., Blackburn J.K., Sansyzbayev Y. Using a geographic information system to spatially investigate infectious disease. In: M. Tibayrenc ed. Encyclopedia of infectious diseases: modern methodologies, London, John Wiley \& Sons, Inc. Publ., Hoboken, New Jersey, 2007, 800 p.

7. Blackburn J.K. Integrating Geographic Information Systems and Ecological Niche Modeling into Disease Ecology: A Case Study of Bacillus anthracis in the United States and Mexico. Emerging and Endemic Pathogens: Conference proceedings. Part of the NATO Science for Peace and Security Series A: Chemistry and Biology. Dordrecht, Springer, 2010, pp. 59-88. DOI: 10.1007/978-90-481-9637-1_7

8. Simonova E.G., Kartavaya S.A., Titkov A.V., Loktionova M.N., Raichich S.R., Tolpin V.A., Lupyan E.A., Platonov A.E. Anthrax in the territory of Yamal: assessment of epizootiological and epidemiological risks. Problemy osobo opasnykh infektsii, 2017, no. 1, pp. 89-93 (in Russian). DOI: 10.21055/0370-1069-2017-1-89-93

9. Selyaninov Yu.O., Egorova I.Yu., Kolbasov D.V., Listishenko A.A. Anthrax in Yamal: reemergence causes and diagnostic issues. Veterinariya, 2016, no. 10, pp. 3-7(in Russian).

10. Simonova E.G., Raichich S.R., Kartavaya S.A., Loktionova M.N., Shabeikin A.A. Manifestation of Activity of Potentially Hazardous as regards Anthrax Areas across the Russian Federation under Current Conditions. Problemy osobo opasnykh infektsii, 2018, no. 2, pp. 90-94 (in Russian).

11. Marinin L.I., Dyatlov I.A., Shishkova N.A., Gerasimov V.N. Sibireyazvennye skotomogil'niki: problem i resheniya [Burial grounds of cattle that contain anthrax: problems and solution to them]. Moscow, Dinastiya Publ., 2017, 216 p. (in Russian).

12. Kadastr statsionarno neblagopoluchnykh po sibirskoiy azve punktov Rossiiskoi Federatsii [The cadastre of territories in the RF that are stationary unfavorable in terms of anthrax]. In: B.L. Cherkasskii ed. Moscow, 2005, 829 p. (in Russian). 
13. Pokrovskii V.I., Onishchenko G.G., Cherkasskii B.L. Evolyutsiya infektsionnykh boleznei v Rossii $\mathrm{v}$ XX veke [Evolution of infectious diseases in Russia in the $20^{\text {th }}$ century]. Moscow, Meditsina Publ., 2003, 589 p. (inRussian).

14. Eremenko E.I., Ryazanova A.G., Buravtseva N.P., Tsygankova O.I., Aksenova L.Yu. [et al.]. Evaluation of Anthrax Morbidity Rate in 2012, Prognosis for 2013. Problemy osobo opasnykh infektsii, 2013, no. 1, pp. 18-21 (in Russian).

15. Ryazanova A.G., Ezhlova E.B., Pakskina N.D., Semenova O.V., Aksenova L.Y., Eremenko E.I., Buravtseva N.P., Golovinskaya T.M. [et al.]. Epidemiological Situation on Anthrax in 2018, the Forecast for 2019. Problemy osobo opasnykh infektsii, 2019, no. 1, pp. 98-102 (in Russian). DOI: 10.21055/03701069-2019-1-98-102

16. Schmid G., Kaufmann A. Anthrax in Europe: its epidemiology, clinical characteristics, and role in bioterrorism. Clin. Microbiol. Infect, 2002, no. 8, pp. 479-488. DOI: 10.1046/j.14690691.2002.00500.x

17. Anthrax in humans and animals. Fourth edition. P. Turnbull ed. Geneva, World Health Organization, 2008, pp. 89-100. Available at: https://www.who.int/csr/resources/publications/anthrax_webs.pdf (03.03.2019).

18. Blackburn J.K., McNyset K.M., Hugh-Jones M.E., Curtis A. Modeling the geographic distribution of Bacillus anthracis, the causative agent of anthrax disease, for the contiguous United States using predictive ecological niche modeling.Am. J. Trop. Med. Hyg., 2007, vol. 77, pp. 1103-1110. DOI: 10.4269 ajtmh.16-0758

19. Van Ness G.B. Ecology of anthrax. Science, 1971, vol. 172, no. 3990, pp. 1303-1307. DOI: 10.1126/science.172.3990.1303

20. Helgason E., Okstad O.A., Caugant D.A., Johansen H.A., Fouet A., Mock M., Hegna I., Kolsto A.B. Bacillus anthracis, Bacillus cereus, and Bacillus thuringiensis - one species on the basis of genetic evidence. Applied and Environmental Microbiology, 2000, vol. 66, pp. 2627-2630. DOI: 10.1128/aem.66.6.2627-2630.2000

Simonova E.G., Shabeikin A.A., Raichich S.R., Loktionova M.N., Saburova S.A., Patyashina M.A., Ladnyi V.I., Gulyukin A.M. Geoinformation technologies for assessing epizootologic and epidemiologic situation with anthrax. Health Risk Analysis, 2019, no. 3, pp. 74-82. DOI: 10.21668/health.risk/2019.3.09.eng

Received: 19.03 .2019

Accepted: 08.08.2019

Published: 30.09.2019 


\title{
MEDICAL AND BIOLOGICAL ASPECTS RELATED TO ASSESSMENT OF IMPACTS EXERTED BY RISK FACTORS
}

UDC 504.75

DOI: 10.21668/health.risk/2019.3.10.eng

Read

online

\section{UNIVERSAL THERMAL CLIMATE INDEX (UTCI) APPLIED TO DETERMINE THRESHOLDS FOR TEMPERATURE-RELATED MORTALITY}

\author{
N.V. Shartova ${ }^{1}$, D.A. Shaposhnikov ${ }^{2}$, P.I. Konstantinov ${ }^{1}$, B.A. Revich ${ }^{2}$ \\ ${ }^{1}$ Moscow State University, 12 Bldg., 1 Leninskie Gory, Moscow, 119991, Russian Federation \\ ${ }^{2}$ The Institute of Economic Forecasting of the Russian Academy of Sciences, 47 Nakhimovskii Ave., Moscow, \\ 117418, Russian Federation
}

Our research goal was to examine a response in mortality among population in Arkhangelsk caused by exposure to high and low temperatures. We determined the best available mortality predictor out of air temperature and Universal Thermal Climate Index that characterizes how people feel temperature and detected threshold temperatures depending on sex, age, and cause of death; under exposure to such temperatures there was a statistically authentic increase in mortality.

We analyzed data on daily mortality among population and meteorological data collected in 1999-2016. Relative preciseness in calculating attributive fractions of additional mortality during all hot and cold days was taken as a numeric criterion for selecting the best predictor. All the calculations were accomplished basing on Poisson's regression model taking into account a non-linear dependence between mortality and weather with a distributed lag up to 21 days long.

Although people in Arkhangelsk live in a climate with cold summer and moderately cold winter, we determined attributive fractions of mortality both for cold and heat. In summer high temperatures at night have greater effects on mortality than average daily ones. Differences in temperature-related mortality depend not only on age (people who are older than 65 are more vulnerable in this respect) but also on sex. We detected lower threshold heat temperatures for males as well as greater increase in mortality among them caused by exposure to cold. It is advisable to use different predictors to obtain the maximum precise characteristics for heat and cold stress. We recommend applying UTCI to determine threshold temperatures and additional mortality.

Key words: heat waves, cold waves, mortality, population, circulatory organs diseases, cerebrovascular diseases, respiratory organs diseases, Universal Thermal Climate Index (UTCI), Arkhangelsk.

At present there are a lot of data on an increase in mortality caused by exposure to extreme cold or hot temperatures. These data have been accumulated in various research; and issues related to influences exerted by climatic and weather conditions on population health still remain vital, especially taking into account abnormal climatic phenomena like extremely hot summer in 2019. Extreme cold or heat has been proved to be a risk factor that can cause additional death cases, primarily due to diseases in the circulatory system and respiratory organs [1-3]. Influence exerted by heat on population mortality has been studied profoundly, especially due to global warming [4] whereas exposure to cold and effects produced by it have been given much less attention [5].

Developing timely preventive activities requires better and more precise insight into all peculiarities of a relationship between mortality and air temperature. Among other things, it is important to reveal differences in suscepti-

(C) Shartova N.V., Shaposhnikov D.A., Konstantinov P.I., B.A. Revich, 2019

Natalia V. Shartova - Candidate of Geographical Sciences, senior researcher (e-mail: shartova@yandex.ru; tel.: +7 (495) 939-21-40; ORCID: https://orcid.org/0000-0003-2758-9612).

Dmitrii A. Shaposhnikov - Candidate of Physical and Mathematical Sciences, senior researcher (e-mail: dshap2014@gmail.com; tel.: +7(499) 129-36-33; ORCID: https://orcid.org/0000-0001-9191-1974).

Pavel I. Konstantinov - Candidate of Geographical Sciences, senior lecturer (e-mail: kostadini@mail.ru; tel.: +7 (495) 939-29-42; ORCID: https://orcid.org/0000-0001-5064-155X).

Boris A. Revich - Doctor of Medical Sciences, Professor, Head of Laboratory for Environment Quality Prediction and Population Health (e-mail: brevich@yandex.ru; tel.: +7 (499) 129-36-33; ORCID: https://orcid.org/0000-0002-7528-6643). 
bility to temperature among various population groups depending on a sex and age; it is also necessary to improve prediction techniques applied to determine a response in mortality to changes in weather conditions. Recently bioclimatic indexes have been widely used as promising mortality predictors due to their ability to give a more precise insight into people's sensation of warmth or cold as compared with air temperature [6].

People who live in arctic regions in Russia where apparent climatic changes occur can be considered one of the most vulnerable population groups in this respect. Such people can have different adaptive capacities as regards exposure to heat or cold. Given all that, our research goal was to examine a response in mortality to exposure to heat and cold among population in Arkhangelsk. For several years Arkhangelsk has been a model territory where impacts exerted by air temperature and temperature waves on mortality among population have been examined. The first research was accomplished within a project of the WHO Regional Office for Europe and focused on adaptation of public healthcare systems to climatic changes. Experts who conducted the research applied Poisson's model to determine additional mortality caused by temperature exposures [7]. The consequent research yielded a significant result as it allowed obtaining a numerical forecast on expected additional mortality among population living in this city; it was also shown that by 2040-2059 a decrease in mortality in cold season will compensate for an increase in it during summer, and an overall effect produced by warming is quite favorable as there should be an approximately $2 \%$ decrease in average annual mortality [8]. Different bioclimatic indexes were assessed in Arkhangelsk, Murmansk, and Yakutsk when experts tried to determine relative rises in mortality during heat and cold waves [9]. Heat and cold waves are discrete weather phenomena; therefore, risks that occur during such waves are characterized not only with temperature-depending mortality, as is the case with the present work, but also with duration of uninterrupted exposure to extreme tempera- tures. Hence, it is advisable to apply specific models of mortality in such studies; for example, those that take into account an ordinal number of a day since a wave has started. In particular, it was shown that in Arkhangelsk ordinary temperature was more closely related to mortality during heat waves than effective one. In the present work we, for the first time in Russia, have examined a possibility to apply a bioclimatic index UTCI as a marker of a temperature-induced stress and also used standard statistical numerical procedures to test a hypothesis that has been often stated in multiple research, namely, that high nighttime temperature might exert greater influence than daytime one during hot season due to people being unable to get their usual night rest from heat.

We aimed to solve two major tasks in our research: (1) to determine the best available predictor out of the examined ones (air temperature and a bioclimatic index UTCI) separately for cold and hot seasons; (2) to determine threshold temperatures for the chosen predictor under exposure to which there is a statistically authentic increase in mortality; the temperatures were to be determined depending on a sex, age, and a cause of death.

\section{Data and methods}

Examined region

Arkhangelsk is located in a geographical zone with moderate climate with some features of marine one, with a correction for the geographic latitude $\left(64^{\circ} \mathrm{n} .1\right.$., approximately $220 \mathrm{~km}$ to the south from the Arctic Circle). Summers are usually short and cool there and winters are long and moderately cold. As the city is located on the sea, there can often be drastic changes in weather conditions (for example, caused by ultrapolar cold invasions from the Kara Sea). Annual temperature range amounts to $29.1^{\circ} \mathrm{C}$ [10], resulting from average monthly temperature in January, the coldest month $\left(-12.8^{\circ} \mathrm{C}\right)$, and in July, the warmest one $\left(16.3^{\circ} \mathrm{C}\right)$.

\section{Statistical data on mortality}

We took data on daily mortality (an absolute number of deaths) in Arkhangelsk for each day from 1999 to 2016. We analyzed mortality by all natural causes of death excluding any external impacts; we also studied mor- 
tality rates as regards circulatory system diseases (CSD) including ischemic heart disease (IHD), cerebrovascular diseases (CVD), and diseases of respiratory system (DRS). Statistical data on all the above mentioned parameters were examined separately for different sex and age groups, with spotting out separate age groups of people aged 30-64 and older than 65. Overall, we used 10 mortality rates separately for men and women.

Testing sufficiency of mortality data for modeling

To test whether we had sufficient data for regression analysis, we calculated average daily mortality $(\mu)$ over the examined period. Taking into account the overall number of degrees of freedom in the statistical model for mortality, we can state that $\mu \leqslant 0.24$ is the bottom limit for conditions of Gauss-Markov theorem to be met. If $\mu$ has smaller values, statistical power of a sampling is not sufficient for obtaining reliable regression results. As regards parameters that we chose for our research, $\mu$ values for them varied from 0.03 cases per day (mortality among women aged 30-64 caused by DRS) to 5.0 cases per day (mortality caused by all natural reasons among women older than 65).

We revealed that mortality caused by DRS among men and women in both age groups didn't have sufficient statistical power; it was also the case with IHD and CVD among women and CVD among men aged 30-64. We took this fact into account when interpreting our results further.

\section{Temperature predictors of mortality}

We applied two basic temperature predictors to examine impacts exerted by heat and cold on mortality among population; they were air temperature $(\mathrm{T})$ and Universal Thermal Climate Index (UTCI). The latter has an advantage of being universal as it is calculated within a temperature range from -50 to $+50^{\circ} \mathrm{C}$. This index takes into account a physiological model of human energy balance and is such an equivalent temperature for a given combination of wind speed, solar radiation, humidity, and air temperature that would give the same feeling of weather under etalon conditions
[11]. A relevant estimation scale was developed on the basis of modeled physiological reactions and included 10 categories starting from extreme cold stress (lower than $-40^{\circ} \mathrm{C}$ ) to extreme heat stress (higher than $+46^{\circ} \mathrm{C}$ ).

Our first research task was to select the most informative mortality predictor that would give the most exact forecast on a temperaturerelated component in mortality separately for all hot and cold days over the examined period. Temperature dependence of mortality has an apparent minimum, so called MMT or minimum mortality temperature. All days during which temperature was higher than MMT were considered to be "hot"; and those during which temperature was lower than MMT were "cold". We chose the best predictor out of six for hot days: average daily temperature, maximum temperature during a day and at night, and UTCI. We chose one of four predictors for cold days: average daily temperature, minimum daily temperature, and UTCI (Table 1). Night temperatures were taken between 10 p.m. and 8 a.m. next day. We took data obtained via eight routine observations over daily meteorological parameters at Arkhangelsk weather stations (Index WMO 22550). UTCI index was calculated with Rayman software package [12].

Table 1

Temperature predictors in examining influence exerted by heat and cold on mortality

\begin{tabular}{|l|c|c|}
\hline $\begin{array}{r}\text { Temperature } \\
\text { predictor }\end{array}$ & $\begin{array}{c}\text { Influence } \\
\text { by heat }\end{array}$ & $\begin{array}{c}\text { Influence } \\
\text { by cold }\end{array}$ \\
\hline $\mathrm{T}_{\text {day_max }}$ & $\boldsymbol{V}$ & - \\
\hline $\mathrm{T}_{\text {night_max }}$ & $\boldsymbol{V}$ & - \\
\hline $\mathrm{T}_{\text {mean }}$ & - & $\checkmark$ \\
\hline $\mathrm{T}_{\text {min }}$ & $\boldsymbol{V}$ & - \\
\hline $\mathrm{UTCI}_{\text {day_max }}$ & $\boldsymbol{V}$ & - \\
\hline $\mathrm{UTCI}_{\text {night_max }}$ & $\boldsymbol{V}$ & $\checkmark$ \\
\hline $\mathrm{UTCI}_{\text {mean }}$ & - & $\checkmark$ \\
\hline $\mathrm{UTCI}_{\text {min }}$ & & \\
\hline
\end{tabular}

Notes:

"day_max" means maximum temperature at daytime,

"night_max" means maximum temperature at nighttime, "mean" is daily average,

"min" is minimum temperature during a day;

" $\checkmark$ " means an index was taken for research. 
Our numeric criterion for selecting the best predictor was precision in calculating attribute fractions of additional mortality during all hot and cold days ( $A F_{\text {heat }}$ and $\left.A F_{\text {cold }}\right)$. This precision was characterized with a relative standard error (RSE) in estimated value of these parameters calculated on the basis of comparable mortality models. RSE $\leq 0.5$ means that $\mathrm{AF}$ estimation is authentic at $95 \%$ level and it corresponds to Student's $t=1 / \mathrm{RSE}>1.96$. We calculated population attribute fraction $A F_{X}$ and attribute number of outcomes $A N_{x}$ for a given exposure $x$ on the basis of Poisson's model as per a procedure given in [13]. Attribute number of deaths was calculated relative to a hypothetic situation when a temperature during a day $i$ was equal to MMT. It is possible to determine cumulative relative risk $R R_{\text {overall }}$ accumulated within a population during a time period equal to $L$ days after exposure to air temperature $T_{i}$, as an increase in mortality on average per 1 day in a period of exposure relative to a hypothetic situation given above. This possibility is provided by models with a distributed lag when it is assumed that an exposure lasts for $L$ days and after this period is over any further exposure can be neglected. Attribute number of deaths $A N\left(T_{i}\right)$ accumulated within a population during $L$ days after an exposure to temperature $T_{i}$, is determined as an average excess of daily mortality $M_{i}$ over minimum mortality $M M$ :

$$
\begin{aligned}
A N\left(T_{i}\right) & =\frac{\sum_{\text {lag=0 }}^{L}\left(M_{i+l a g}-M M\right)}{(L+1)}= \\
& =\left(R R_{\text {overall }}-1\right) M M .
\end{aligned}
$$

To calculate an estimated value of attribute mortality $\widehat{A N}_{i}$ over all days in the given period, we applied a distributed lag non-linear model-; it is described in details in [14]. There was previous research conducted in largest cities such as London and New-York where qualitative statistical data on daily mortality were available; that research revealed that three weeks were quite enough to be considered a maximum lag $L$ during which an effect produced by exposure to extreme temperatures reached its maximum [15]. We applied the same lag in our work. We summed up $\widehat{A N}_{i}$ over all the days in the examined period and obtained total attribute mortality $\widehat{A N}_{\text {tot }}$ which could be divided into two summands corresponding to all the days with temperatures higher than optimal ( $\widehat{A N}_{\text {heat }}$ ) and all days with temperatures lower than optimal ( $\left.\widehat{A N}_{\text {cold }}\right)$. After that we determined attribute fractions for heat and cold:

$$
\widehat{A F}_{\text {cold }}=\frac{\widehat{A N}_{\text {cold }}}{M_{\text {tot }}} ; \quad \widehat{A F}_{\text {heat }}=\frac{\widehat{A N}_{\text {heat }}}{M_{\text {tot }}},
$$

where $M_{\text {tot }}$ is total mortality over all the days in the examined period. User-defined function attrdl.R applied to calculate these parameters in $\mathrm{R}$ software (R-package dlnm2.2.0) and is available in online-application to the work [13]. This function also allows calculating empirical confidence intervals (CI) around attribute fractions with Monte-Carlo method assuming that model coefficients are normally distributed. Having looked through mortality models with alternative temperature predictors from Table 1, we found the best one that allowed minimizing a relative standard error in calculating attribute fractions.

Our second research task was to calculate heat and cold thresholds for the most informative predictors. Due to finiteness of a primary data array applied for modeling, MMT value was determined approximately as a model estimate. Given that, we applied an empirical procedure for assessing standard deviation and 95\% confidence interval of MMT; the procedure was suggested in the work [16]. The right (upper) limit of MMT 95\% confidence interval was considered to be a required "heat threshold"; an increase in mortality that exceeded it became statistically authentic. The left (bottom) limit of the interval was considered to be a required "cold threshold".

The final stage in our research involved linearizing obtained dependences of cumulative relative risks $R R_{\text {overall }}(T)$ for predictors with the best predicting capacity. A relative increase in mortality during hot weather was calculated per 1 degree of an increase in a pre- 
dictor value on average within a range from MMT to 97.5-percentile of its historical longterm distribution; for cold weather, it was calculated per 1 degree of temperature drop within a range from MMT to 2.5-percentile.

Results and discussion. Our assessment and analysis of average UTCI values over 1999-2016 revealed that bioclimatic conditions in Arkhangelsk tended to be comfortable since June till September as there was no temperature stress, and the index values varied within $+9 \ldots+26{ }^{\circ} \mathrm{C}$ (Figure 1). There was a strong cold stress in January and February $\left(-13 \ldots-27^{\circ} \mathrm{C}\right)$; as for all the other months, a stress was moderate or slight $\left(+9 \ldots-13{ }^{\circ} \mathrm{C}\right)$.

Tables 2 and 3 contain data which we applied to select the best predictor via minimizing a relative standard error in determining an attribute fraction of mortality for cold and hot weather. We obtained convincing evidence both for cold and hot weather that allowed us to make a choice on the "best" one out of several possible predictors; that is, a predictor that was the most closely related to mortality from a statistical point of view.

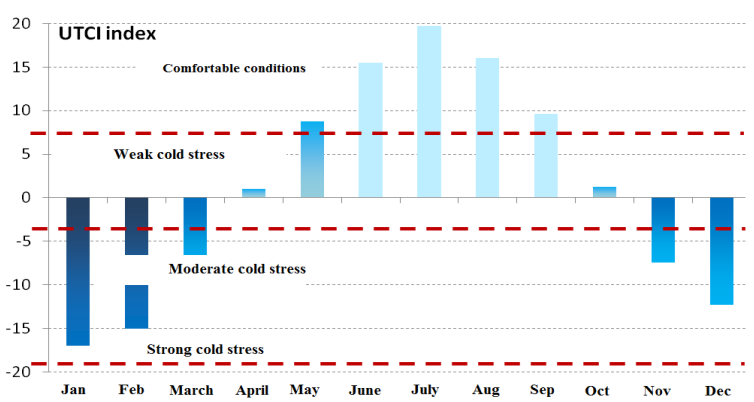

Figure 1. Average monthly values of UTCI $\left({ }^{\circ} \mathrm{C}\right)$ in Arkhangelsk in 1999-2016

Table 2

Attribute fractions for heat $\left(\mathrm{AF}_{\text {heat }}\right)$, minimum relative standard error in estimation (RSE) is given in bold

\begin{tabular}{|c|c|c|c|c|c|c|c|c|c|c|c|c|c|}
\hline \multirow{2}{*}{$\begin{array}{c}\text { Cause } \\
\text { of death }\end{array}$} & \multicolumn{2}{|c|}{$\mathrm{T}_{\mathrm{day} \_\max }$} & \multicolumn{2}{|c|}{$\mathrm{T}_{\text {night max }}$} & \multicolumn{2}{|c|}{$\mathrm{T}_{\text {mean }}$} & \multicolumn{2}{|c|}{ UTCI $_{\text {day max }}$} & \multicolumn{2}{|c|}{$\mathrm{UTCI}_{\text {night max }}$} & \multicolumn{2}{|c|}{$\mathrm{UTCI}_{\text {mean }}$} & \multirow{2}{*}{$\begin{array}{c}\text { best } \\
\text { predictor }\end{array}$} \\
\hline & $\mathrm{AF}_{\text {heat }}$ & RSE & $\mathrm{AF}_{\text {heat }}$ & RSE & $\mathrm{AF}_{\text {heat }}$ & RSE & $\mathrm{AF}_{\text {heat }}$ & RSE & $\mathrm{AF}_{\text {heat }}$ & RSE & $\mathrm{AF}_{\text {heat }}$ & RSE & \\
\hline \multicolumn{14}{|c|}{ Women aged 30-64 } \\
\hline IHD & 0.001 & 7.000 & 0.0000 & NA & 0.001 & 7.450 & NA & & 0.004 & 2.563 & 0.0000 & NA & $\mathrm{UTCI}_{\mathrm{ni}}$ \\
\hline CVD & NA & & NA & & NA & & NA & & NA & & NA & & \\
\hline CSD & NA & & NA & & NA & & NA & & NA & & NA & & \\
\hline$\overline{\mathrm{DRS}}$ & 0.025 & 0.600 & 0.25 & 1.090 & 0.27 & 1.056 & 0.015 & 1.283 & 0.016 & 1.438 & \begin{tabular}{|l|}
0.010 \\
\end{tabular} & 2.025 & \\
\hline All na & 0.0025 & 1.800 & NA & & 0.0003 & 6.333 & 0.0011 & 2.864 & 00 & NA & 0.000 & NA & \\
\hline \multicolumn{14}{|c|}{ Women older than 65} \\
\hline HD & 0.0016 & 2.141 & 0.0012 & 2.146 & 0.0005 & 3.800 & 0.0000 & NA & 0.0019 & 1.803 & NA & & $\overline{T C}$ \\
\hline CVD & 025 & 720 & 0.004 & 1.188 & 0. & 4.536 & 0.001 & 3.000 & 43 & 1.052 & .0010 & 3.350 & TC \\
\hline CSD & 0.0032 & 0.938 & 0.0034 & 0.787 & 0.0014 & 1.696 & 0.0010 & 1.850 & 40 & 0.681 & 0.0010 & 1.925 & TC \\
\hline DRS & 0.019 & 0.658 & 0.013 & 1.000 & 0.013 & 0.846 & 0.016 & 0.750 & 16 & 0.672 & \begin{tabular}{|l|}
0.014 \\
\end{tabular} & 0.857 & \\
\hline All $\mathrm{n}$ & 0.0030 & 0.933 & 0.0036 & 0.681 & 0.0015 & 0.741 & 0.0010 & 1.850 & 0.0041 & 0.622 & 0.0013 & 1.500 & UTCI \\
\hline \multicolumn{14}{|c|}{ Men aged 30-64 } \\
\hline $\mathrm{HD}$ & $\mathrm{NA}$ & & $\mathrm{NA}$ & & $\mathrm{NA}$ & & NA & & $\mathrm{NA}$ & & $\mathrm{NA}$ & & \\
\hline VD & 0.002 & 3.625 & 0.20 & 0.913 & 0.20 & 0.838 & 0.25 & 0.670 & 0.13 & 1.404 & 0.22 & 0.716 & UTCI \\
\hline SD & NA & & NA & & NA & & NA & & NA & & NA & & \\
\hline DRS & $\mathrm{A}$ & & NA & & NA & & NA & & NA & & NA & & \\
\hline All na & 0.0033 & 1.053 & 0.0042 & 0.750 & 0.0035 & 0.893 & 0.0015 & 1.917 & 0.0042 & 0.851 & 0.0024 & 1.260 & \\
\hline \multicolumn{14}{|c|}{ Men older than 65} \\
\hline IHD & 0.007 & 0.893 & 0.0083 & 0.711 & 0.008 & 0.719 & 0.006 & 0.921 & $0.013 *$ & 0.442 & \begin{tabular}{|l|}
0.008 \\
\end{tabular} & 0.719 & $\mathrm{UTCI}_{\mathrm{n}}$ \\
\hline CVD & 0.000 & NA & 0.003 & 3.250 & \begin{tabular}{|l|}
0.003 \\
\end{tabular} & 2.833 & 0.003 & 3.250 & 0.003 & 3.250 & \begin{tabular}{|l|}
0.003 \\
\end{tabular} & 2.833 & UTCI \\
\hline CSD & 0.005 & 1.150 & 0.006 & 0.833 & \begin{tabular}{|l|}
0.005 \\
\end{tabular} & 0.950 & 0.005 & 1.000 & $0.009 *$ & 0.500 & \begin{tabular}{|l|}
0.0062 \\
\end{tabular} & 0.694 & UTC \\
\hline DRS & NA & & NA & & NA & & NA & & NA & & NA & & \\
\hline All natural & 0.0010 & 4.100 & \begin{tabular}{|l|}
1 \\
0.002 \\
\end{tabular} & 12.250 & \begin{tabular}{|l|}
1711 \\
0.002 \\
\end{tabular} & 2.000 & 0.0014 & 2.714 & 0.006 & \begin{tabular}{|l|}
0.667 \\
\end{tabular} & 0.0033 & 1.144 & \\
\hline
\end{tabular}

*means an $\mathrm{AF}$ value is authentic at 95\%-th level. 
Table 3

Attribute fractions for cold $\left(\mathrm{AF}_{\text {cold }}\right)$, minimum relative standard error in estimation (RSE) is given in bold

\begin{tabular}{|c|c|c|c|c|c|c|c|c|c|}
\hline \multirow{2}{*}{$\begin{array}{c}\text { Cause } \\
\text { of death }\end{array}$} & \multicolumn{2}{|c|}{$T_{\text {mean }}$} & \multicolumn{2}{|c|}{$\mathrm{T}_{\min }$} & \multicolumn{2}{|c|}{$\mathrm{UTCI}_{\text {mean }}$} & \multicolumn{2}{|c|}{$\mathrm{UTCI}_{\min }$} & \multirow{2}{*}{$\begin{array}{c}\text { best } \\
\text { predictor }\end{array}$} \\
\hline & $\mathrm{AF}_{\text {cold }}$ & RSE & $\mathrm{AF}_{\text {cold }}$ & RSE & $\mathrm{AF}_{\text {cold }}$ & RSE & $\mathrm{AF}_{\text {cold }}$ & RSE & \\
\hline \multicolumn{10}{|c|}{ Women aged 30-64 } \\
\hline IHD & 0.27 & 0.741 & 0.38 & 1.974 & 0.22 & 1.511 & 0.29 & 2.897 & $T_{\text {mean }}$ \\
\hline CVD & 0.75 & 0.360 & NA & NA & 0.79 & 0.320 & NA & NA & $\mathrm{UTCI}_{\text {mean }}$ \\
\hline CSD & 0.50 & 0.460 & NA & NA & 0.50 & 0.505 & $0.72 *$ & 0.229 & $\mathrm{UTCI}_{\min }$ \\
\hline DRS & 0.031 & 0.452 & 0.038 & 0.434 & 0.23 & 2.554 & 0.031 & 0.863 & $\mathrm{~T}_{\min }$ \\
\hline All natural & 0.22 & 0.443 & 0.49 & 0.383 & 0.23 & 0.467 & 0.39 & 0.571 & $T_{\min }$ \\
\hline \multicolumn{10}{|c|}{ Women older than 65} \\
\hline IHD & $0.29 *$ & 0.276 & 0.45 & 0.394 & $0.28^{*}$ & 0.393 & $0.56^{*}$ & 0.290 & $\mathrm{~T}_{\text {mean }}$ \\
\hline CVD & $0.19 *$ & 0.447 & 0.22 & 1.273 & 0.21 & 0.464 & 0.22 & 1.364 & $\mathrm{~T}_{\text {mean }}$ \\
\hline CSD & $0.22 *$ & 0.250 & 0.27 & 0.602 & $0.21 *$ & 0.310 & 0.32 & 0.477 & $T_{\text {mean }}$ \\
\hline DRS & 0.43 & 0.576 & NA & NA & 0.38 & 0.770 & 0.20 & 1.025 & $\mathrm{~T}_{\text {mean }}$ \\
\hline All natural & $0.15^{*}$ & 0.367 & 0.18 & 0.861 & $0.14^{*}$ & 0.411 & 0.23 & 0.630 & $\mathrm{~T}_{\text {mean }}$ \\
\hline \multicolumn{10}{|c|}{ Men aged 30-64 } \\
\hline IHD & 0.37 & 0.534 & 0.32 & 0.867 & 0.42 & 0.458 & $0.24 *$ & 0.448 & $\mathrm{UTCI}_{\min }$ \\
\hline CVD & 0.001 & 6.750 & 0.000 & NA & 0.001 & 6.500 & 0.003 & 3.667 & $\mathrm{UTCI}_{\min }$ \\
\hline $\mathrm{CSD}$ & 0.21 & 0.940 & 0.16 & 0.750 & 0.22 & 0.977 & 0.15 & 0.550 & $\mathrm{UTCI}_{\min }$ \\
\hline DRS & 0.42 & 1.214 & 0.56 & 0.929 & 0.48 & 1.130 & 0.50 & 1.280 & $\mathrm{~T}_{\min }$ \\
\hline All natural & $0.14 *$ & 0.446 & $0.17 *$ & 0.368 & $0.14 *$ & 0.464 & $0.17 *$ & 0.353 & $\mathrm{UTCI}_{\min }$ \\
\hline \multicolumn{10}{|c|}{ Men older than 65} \\
\hline IHD & $0.26^{*}$ & 0.385 & $0.26^{*}$ & 0.356 & $0.31 *$ & 0.315 & $0.27 *$ & 0.352 & $\mathrm{UTCI}_{\text {mean }}$ \\
\hline CVD & 0.16 & 0.891 & 0.19 & 0.697 & 0.20 & 0.738 & 0.22 & 0.580 & $\mathrm{UTCI}_{\min }$ \\
\hline CSD & $0.20 *$ & 0.413 & $0.21 *$ & 0.369 & $0.25^{*}$ & 0.340 & $0.25^{*}$ & 0.300 & $\mathrm{UTCI}_{\min }$ \\
\hline DRS & 0.49 & 1.250 & 0.55 & 1.445 & 0.62 & 1.113 & 0.70 & 0.868 & $\mathrm{UTCI}_{\min }$ \\
\hline All natural & 0.10 & 0.725 & 0.12 & 0.563 & 0.15 & 0.483 & $0.15^{*}$ & 0.417 & $\mathrm{UTCI}_{\min }$ \\
\hline
\end{tabular}

* means an AF value is authentic at $95 \%$-th level

The most convincing results were obtained for hot weather. It was possible to select the best predictor only for 14 parameters (we didn't obtain any temperature-related dependences for high temperatures for the remaining 6 parameters). The UTCI nighttime maximum (UTCI night_max $\left._{\text {max }}\right)$ which we chose out of 6 alternative predictors turned out to be the best one in 11 cases out of 14 .

We obtained reliable $\mathrm{AF}_{\text {heat }}$ estimations only for two parameters out of 20, namely IHD and CSD in men older than 65; it proves that elderly people are too sensitive to negative impacts exerted by heat as it was also confirmed in some previous research $[3,17,18]$.

During cold days predictors turned out to have different predictive capacity depending on a sex. Average daily temperature $\mathrm{T}_{\text {mean }}$ was a better predictor for women (for 6 mortality parameters out of ten). As for men, the best predictor for them was minimum daily $\mathrm{UTCI}_{\text {min }}$ (for 8 out of 10 parameters). At the moment we can't give any authentic explanation for the detected sexdependent differences in predictors. Among other things, they can be caused by differences in physical and social activity of men and women in winter. UTCI was chosen as a probable mortality predictor during a cold season in research conducted in Czech Republic [19] and Iran [20].

We obtained a lot more statistically authentic estimations of AF for exposure to cold (both for men and women); these estimations were detected for all the chosen pathologies excluding DRS. And not only elderly people but also younger age groups (30-64 years) were sensitive to this exposure. 
Table 4

Temperature that corresponds to MMT; heat and cold thresholds, relevant increases in mortality $(\%)$ per $1{ }^{\circ} \mathrm{C}$ increase in exposure

\begin{tabular}{|c|c|c|c|c|c|c|c|c|}
\hline \multirow[b]{2}{*}{$\begin{array}{l}\text { Cause } \\
\text { of death }\end{array}$} & \multicolumn{4}{|c|}{ Heat } & \multicolumn{4}{|c|}{ Cold } \\
\hline & $\begin{array}{c}\text { MMT } \\
(\%)\end{array}$ & $\begin{array}{c}\text { MMT } \\
\left({ }^{\circ} \mathrm{C}\right)\end{array}$ & $\begin{array}{c}\text { Heat } \\
\text { threshold } \\
\left({ }^{\circ} \mathrm{C}\right)\end{array}$ & $\begin{array}{c}\text { Relative in- } \\
\text { crease in mortal- } \\
\text { ity }\left(\% \text { per } 1^{\circ} \mathrm{C}\right)\end{array}$ & $\begin{array}{c}\text { MMT } \\
(\%)\end{array}$ & $\begin{array}{c}\text { MMT } \\
\left({ }^{\circ} \mathrm{C}\right)\end{array}$ & $\begin{array}{c}\text { Cold } \\
\text { threshold } \\
\left({ }^{\circ} \mathrm{C}\right)\end{array}$ & $\begin{array}{c}\text { Relative increase } \\
\text { in mortality } \\
\left(\% \text { per } 1^{\circ} \mathrm{C}\right) \\
\end{array}$ \\
\hline \multicolumn{9}{|c|}{ Women aged 30-64 } \\
\hline predictor & \multicolumn{4}{|c|}{ UTCI $_{\text {night max }}$} & \multicolumn{4}{|c|}{$\mathrm{T}_{\text {mean }}$} \\
\hline IHD & 93 & 22.1 & NA & 2.0 & 95 & 19.2 & -12.6 & 2.9 \\
\hline CVD & NA & NA & NA & NA & NA & NA & -8.4 & NA \\
\hline $\mathrm{CSD}$ & NA & NA & NA & NA & NA & NA & -8.1 & NA \\
\hline DRS & 90 & 20.3 & NA & 8.6 & NA & -12 & -17 & NA \\
\hline All natural & $98^{* *}$ & 27 & NA & NA & 97 & 20.7 & -12.5 & $1.3^{*}$ \\
\hline \multicolumn{9}{|c|}{ Women older than 65} \\
\hline IHD & 94 & 23.1 & NA & 1 & 97 & 20.4 & 17.1 & $1.8^{*}$ \\
\hline CVD & 93 & 21.8 & NA & 1.6 & 95 & 19.3 & -10.5 & $1.4^{*}$ \\
\hline CSD & 93 & 21.9 & 30.6 & 1.7 & 95 & 18.8 & 16.8 & $1.4^{*}$ \\
\hline$\overline{\mathrm{DRS}}$ & 90 & 20.1 & NA & 10.2 & 90 & 16.2 & NA & 3.8 \\
\hline All natural & 92 & 21.5 & 26.7 & 1.5 & 95 & 18.4 & -11.8 & $1.0^{*}$ \\
\hline \multicolumn{9}{|c|}{ Men aged 30-64 } \\
\hline predictor & \multicolumn{4}{|c|}{ UTCI $_{\text {night max }}$} & \multicolumn{4}{|c|}{$\mathrm{UTCI}_{\min }$} \\
\hline IHD & NA & NA & NA & NA & 98 & 16.1 & 10.3 & $2.0^{*}$ \\
\hline CVD & NA & NA & NA & NA & NA & NA & NA & NA \\
\hline CSD & $99^{* *}$ & 28.6 & NA & NA & 95 & 13.5 & -20.2 & $1.1^{*}$ \\
\hline DRS & NA & NA & NA & NA & NA & NA & -21.1 & NA \\
\hline All natural & 92 & 21.4 & NA & 1.5 & 93 & 12 & -20.7 & $1.0^{*}$ \\
\hline \multicolumn{9}{|c|}{ Men older than 65} \\
\hline IHD & 90 & 20.2 & 23 & $4.7^{*}$ & 93 & 11.7 & 8.9 & $2.2^{*}$ \\
\hline CVD & 91 & 21 & NA & 0.8 & 89 & 10.1 & -6.3 & $3.4^{*}$ \\
\hline CSD & 90 & 20.3 & 24.7 & 3.1 & 91 & 11.1 & 8.9 & $2.6^{*}$ \\
\hline DRS & NA & NA & NA & & NA & NA & 9.6 & NA \\
\hline All natural & 90 & 20.4 & NA & 1.8 & 91 & 11 & 0.5 & $1.4^{*}$ \\
\hline
\end{tabular}

Note:

$*$ is an authentic increase per $11^{\circ} \mathrm{C}$ at $95 \%$-th level;

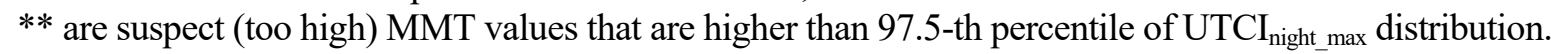

There are heat and cold weather thresholds; when they are reached, there occurs a statistically significant increase in mortality. These thresholds are of great practical interest. The results in Table 4 are given for the best predictors chosen at the previous stage in our research, namely $\mathrm{UTCI}_{\text {night_max }}, \mathrm{T}_{\text {mean }}, \mathrm{UTCI}_{\text {min }}$

MMT values and heat values are given for $\mathrm{UTCI}_{\text {night max. }}$ Overall, MMT parameter was determined for 15 mortality parameters (Table 4). Having excluded suspect values, we concluded that MMT value was most frequently expected between 90 and 94 percentile. It corresponded to $\mathrm{UTCI}_{\text {night } \max }$ index reaching $20-21^{\circ} \mathrm{C}$. We can't possibly expect more exact calculation here. Lower MMT values for $\mathrm{UTCI}_{\text {night max }}$ were detected for men than for women, especially among people older than 65; therefore, men are more sensitive to heat exposure. It confirms the results we obtained in our previous research in Rostov-on-Don that men were more sensitive to a temperature factor than women. Especially in older age groups [14].

Statistically authentic threshold values for heat were determined only for four mortality parameters (CSD and all natural death causes 
for women older than 65 as well as IHD and CSD for men older than 65) that varied from $23.0^{\circ} \mathrm{C}$ to $30.6^{\circ} \mathrm{C}$ for $\mathrm{UTCI}_{\text {night max. Naturally, }}$ the minimum value $+23.0^{\circ} \mathrm{C}$ was the most interesting one since in case there were such maximum UTCI values at nighttime we could expect an authentic increase in mortality caused by IHD among men older than 65 in Arkhangelsk. We didn't detect any authentic heat threshold for age groups that included people aged 30-64.

We calculated a relative increase in mortality in \% per 1 degree Celsius and revealed that they varied from 0.8 to $10.2 \%$ for hot days depending on a specific pathology and sex and age group; but still, practically all obtained results were not significant except from mortality caused by IHD among men older than 65 $\left(4.7 \%\right.$ per $\left.1^{\circ} \mathrm{C}\right)$.

When interpreting cold thresholds for women, we should take into account that "extreme cold threshold" which we require to determine a temperature range for linearizing temperature dependence is equal to $\mathrm{T}_{2.5 \%}=-22.8{ }^{\circ} \mathrm{C}$ for $\mathrm{T}_{\text {mean }}$. As we applied another predictor for men, the relevant 2.5 percentile was $\mathrm{UTCI}_{2.5 \%}=$ $-31,5^{\circ} \mathrm{C}$. The most complicated task was to explain why the determined cold thresholds were heterogeneous and varied from -12.6 to $+17.1^{\circ} \mathrm{C}$ (a 92-th percentile) among women and from 21.1 to $10.3^{\circ} \mathrm{C}$ (a 89-th percentile) among men depending on a parameter.
There can be two possible explanations for this spread. The first is that there is a long "plateau" below MMT within a range of transient year temperatures. It confirms a typical temperature dependence of mortality for Arkhangelsk (Figure 2). In this case differences in plateau length estimations should be considered a modeling artifact (it can be eliminated via greater degrees of freedom when modeling temperature dependence of mortality; however, authenticity of obtained results decreases drastically in this case due to very few lethal outcomes in Arkhangelsk).

The second explanation is that a "true" dependence should be U-like without any plateau; then "true" cold thresholds should be near MMT, that is, they are close to the following maximums: $+17.1^{\circ} \mathrm{C}$ for $\mathrm{T}_{\text {mean }}$ and $+10.3^{\circ} \mathrm{C}$ for $\mathrm{UTCI}_{\min }$ (percentiles of these values are close, $92 \%$ and $89 \%$ ). This or that explanation can be chosen only after testing whether modeling results for MMT CI are stable; such testing can be accomplished only on a big data array on mortality (for example, in a large city with millions of population, for example, in Moscow or Saint Petersburg).

The most significant difference in modeling results for heat and cold is much greater evidence obtained for authentic influence exerted by cold temperatures. For example, Table 4 contains 5 statistically significant results of linearization for women (out of ten) and 7

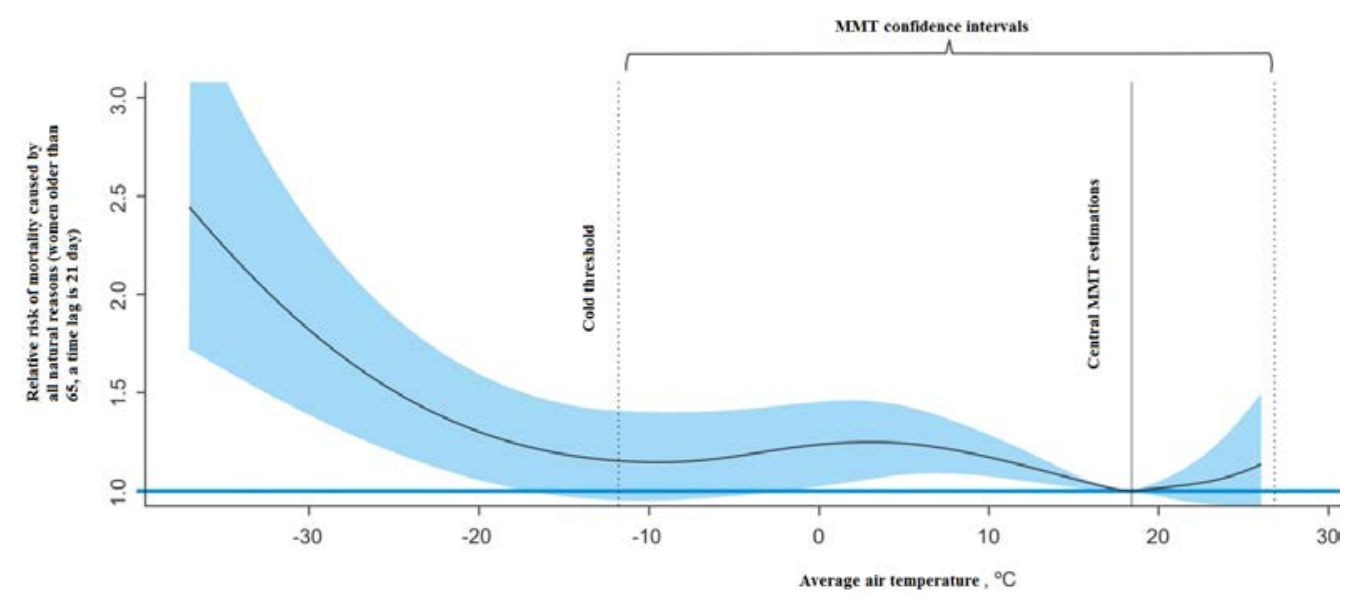

Figure 2. Temperature-dependent mortality caused by all natural reasons among women older than 65 in Arkhangelsk: we can see a plateau within a period of transient autumn and spring temperatures. Solid vertical line shows central MMT estimation, and broken lines show its confidence intervals. A broken line to the left is a cold threshold 
(out of 10) for men. As a rule, results that are not statistically significant are related to insufficient statistical power of mortality samplings (see above). Average increases in mortality per 1-unit decrease in a predictor within cold temperatures range varied from $1.0 \%$ to $1.8 \%$ for women (out of authentic estimations); from $1.0 \%$ to $3.4 \%$, for men. Effects produced by cold were greater for men than for women as it was shown by comparing all the authentically detected increases in mortality in an older age group.

Results which we obtained in this work allow comparing damage to health of population in Arkhangelsk caused by exposure to heat and cold, taking into account specific features of a local climate; it is well in line with bioclimatic conditions existing in the city. People in Arkhangelsk are rarely exposed to heat stress during summer; therefore, we didn't obtain many authentic results about a response in mortality during hot days. High temperatures at nighttime are likely to be the most significant factor that makes its contribution into an increase in mortality during hot weather.

People in Arkhangelsk live under exposure to cold stress during the most part of a year and it causes additional cold-related mortality that was numerically estimated in our research. It is in line with previously obtained results $[8,9]$. For example, experts detected an increase in mortality caused by IHD and natural causes in Archangelsk during cold waves occurring in 1999-2008 [7]. Similar results were obtained in another northern city, Stockholm; research conducted there revealed that a number of additional death cases caused by heat had been decreasing over the last ten years whereas a number of additional death cases caused by cold remained stably high [21]. Most additional death cases caused by
CSD and ROD were related to cold days in some cities in the USA [22], China [23, 24], and many other regions [1]. Therefore, impacts exerted by cold weather on population mortality still remain an outstanding issue in public healthcare.

Conclusion. Although people in Arkhangelsk live in a climate with cool summer and moderately cold winter, we can't neglect impacts exerted by heat on additional death cases. Such impacts become extremely apparent when there are high temperatures at night. It is necessary to work out and implement action plans for both extremely high and cold weather conditions and pay attention to individual precautions, including medications $[25,26]$.

Differences in temperature-related mortality are not only age-dependent (people who are older than 65 are more vulnerable in this respect) but also sex-dependent. As we detected lower heat thresholds for men as well as higher increases in mortality among them during exposure to cold, we can state that their health is more susceptible to such exposure.

As regards heat and cold stresses, it is advisable to apply different predictors. When we analyze heat exposure, we should apply a night maximum for UTCI; when analyzing cold exposure, we should take an average daily temperature (as a mortality predictor for women) and minimum daily UTCI value (as a mortality predictor for men). It is advisable to use UTCI to determine temperature thresholds and additional mortality values.

Funding. The research was given financial support by the Russian fund for fundamental research (Project No. 18-05-60146).

Conflict of interests. The authors declare there is no any conflict of interests.

\section{References}

1. Gasparrini A., Guo Y., Hashizume M., Lavigne E., Zanobetti A., Schwartz J., Tobias A., Tong S. [et al.]. Mortality risk attributable to high and low ambient temperature: a multicountry observational study. Lancet, 2015, no. 386, pp. 369-375. DOI: 10.1016/S0140-6736(14)62114-0

2. Guo Y., Gasparrini A., Armstrong B.G., Li S., Tawatsupa B., Tobias A., Lavigne E., De Sousa Zanotti Stagliorio Coelho M. [et al.]. Global variation in the effects of ambient temperature on mortality: A systematic evaluation. Epidemiology, 2014, vol. 25, no. 6, pp. 781-789. DOI: 10.1097/EDE.0000000000000165 
3. Revich B.A., Shaposhnikov D.A., Avaliani S.L., Rubinshtein K.G., Emelina S.V., Shiryaev M.V., Semutnikova E.G., Zakharova P.V., Kislova O.V. Hazard assessment of the impact of high temperature and air pollution on public health in Moscow. Gigiena i sanitariya, 2015, vol. 94, no. 1, pp. 36-40 (in Russian).

4. Sheridan S.C., Dixon P. Spatiotemporal trends in human vulnerability and adaptation to heat across the United States. Anthropocene, 2017, no. 20, pp. 61-73. DOI: 10.1016/j.ancene.2016.10.001

5. Paschalidou A., Kassomenos P., McGregor G. Analysis of the synoptic winter mortality climatology in five regions of England: Searching for evidence of weather signals. Science of the Total Environment, 2017, vol. 598, pp. 432-444. DOI: 10.1016/j.scitotenv.2017.03.276

6. Di Napoli C., Pappenberger F., Cloke H.L. Assessing heat-related health risk in Europe via the Universal Thermal Climate Index (UTCI). International Journal of Biometeorology, 2018, vol. 62, no. 7, pp. 1155-1165. DOI: $10.1007 / \mathrm{s} 00484-018-1518-2$

7. Varakina Zh.L., Yurasova E.D., Revich B.A., Shaposhnikov D.A., Vyaz`min A.M. Air temperature impact on mortality in Arkhangelsk in 1999-2008. Ekologiya cheloveka, 2011, no. 6, pp. 28-36 (in Russian).

8. Shaposhnikov D.V., Revich B.A., Meleshko V.P., Govorkova V.A., Pavlova T.V., Varakina Zh.L. Experience of predicting of expected excess mortality due to climate change: a case study in Arkhangelsk. Ekologiya cheloveka, 2013, no. 8, pp. 17-22 (in Russian).

9. Revich B.A., Shaposhnikov D.A., Anisimov O.A., Belolutskaia M.A. Heat waves and cold spells in three arctic and subarctic cities as mortality risk factors. Gigiena i sanitariya, 2018, vol. 97, no. 9, pp. 791-798 (in Russian).

10. Konstantinov P.I., Kukanova E.A. Gorodskie ostrova tepla Rossiiskoi Federatsii: osnovnye kharakteristiki i problem izucheniya [Urban heat islands in the Russian Federation: basic features and issues related to examining them]. ENVIROMIS-2014: materialy Mezhdunarodnoi konferentsii $i$ shkoly molodykh uchenykh po izmereniyam, modelirovaniyu i informatsionnym sistemam dlya izucheniya okruzhayushchei sredy. Tomsk, 2014, vol. 29, pp. 162-164 (in Russian).

11. Jendritzky G., Havenith G., Weihs P., Batchvarova E. Towards a Universal Thermal Climate Index UTCI for assessing the thermal environment of the human being. Final Report COST Action 730, 2009, 6 p.

12. Matzarakis A., Endler C. Climate change and thermal bioclimate in cities: impacts and options for adaptation in Freiburg, Germany. International Journal of Biometeorology, 2010, vol. 54, no. 4, pp. 479-483. DOI: $10.1007 / \mathrm{s} 00484-009-0296-2$

13. Gasparrini A., Leone M. Attributable risk from distributed lag models. BMC Medical Research Methodology, 2014. Available at:https://bmcmedresmethodol.biomedcentral.com/articles/10.1186/1471-2288-14-55 (12.03.2018). DOI: 10.1186/1471-2288-14-55

14. Shartova N.V., Shaposhnikov D.A., Konstantinov P.I., Revich B.A. Air temperature and mortality: heat thresholds and population vulnerability study in Rostov-on-don. Fundamental'naya i prikladnaya klimatologiya, 2019, vol. 2, pp. 66-94. DOI: 10.21513/2410-8758-2019-2-66-94 (in Russian).

15. Gasparrini A., Armstrong B., Kenward M.G. Distributed lag non-linear models. Statistics in Medicine, 2010, vol. 29, pp. 2224-2234. DOI: 10.1002/sim.3940

16. Tobías A., Armstrong B.G., Gasparrini A. Brief Report: Investigating Uncertainty in the Minimum Mortality Temperature. Methods and Application to 52 Spanish Cities. Epidemiology, 2017, vol. 28, pp. $72-76$. DOI: $10.1097 / E D E .0000000000000567$

17. Linaresa C., Diaz J. Impact of heat waves on daily mortality in distinct age groups. Gaceta Sanitaria, 2008, vol. 22, no. 2, pp. 115-119.

18. Robine J.M., Michel J.P., Herrmann F.R. Excess male mortality and age-specific mortality trajectories under different mortality conditions: A lesson from the heat wave of summer 2003. Mechanisms of Ageing and Development, 2012, vol. 133, no. 6, pp. 378-386. DOI: 10.1016/j.mad.2012.04.004

19. Urban A., Kyselý J. Comparison of UTCI with other thermal indices in the assessment of heat and cold effects on cardiovascular mortality in the Czech Republic. International Journal of Environmental Research and Public Health, 2014, vol. 11, no. 1, pp. 952-967. DOI: 10.3390/ijerph110100952

20. FallahGhalhari G., Mayvaneh F. Effect of air temperature and universal thermal climate index on respiratory diseases mortality in Mashhad, Iran. Archives of Iranian Medicine, 2016, vol. 19, no. 9, pp. 618-624. DOI: 10161909/AIM.004 
21. Oudin Åström D., Ebi K.L., Vicedo-Cabrera A.M., Gasparrini A. Investigating changes in mortality attributable to heat and cold in Stockholm, Sweden. International Journal of Biometeorology, 2018, vol. 62, no. 9, pp. 1777-1780. DOI: 10.1007/s00484-018-1556-9

22. Zhang Y., Xiang Q., Yu Y., Zhan Z., Hu K., Ding Z. Socio-geographic disparity in cardiorespiratory mortality burden attributable to ambient temperature in the United States. Environmental Science and Pollution Research, 2019, vol. 26, no. 1, pp. 694-705. DOI: 10.1007/s11356-018-3653-z

23. Yang J., Yin P., Zhou M., Ou C.Q., Li M., Li J., Liu X., Gao J. [et al.]. The burden of stroke mortality attributable to cold and hot ambient temperatures: epidemiological evidence from China. Environ. Int., 2016, vol. 92-93, pp. 232-238. DOI: 10.1016/S0140-6736(14)62114-0

24. Yang J., Zhou M., Ou C.Q., Yin P., Li M., Tong S., Gasparrini A., Liu X. [et al.]. Seasonal variations of temperature-related mortality burden from cardiovascular disease and myocardial infarction in China. Environmental Pollution, 2017, vol. 224, pp. 400-406. DOI: 10.1016/j.envpol.2017.02.020

25. Smirnova M.D., Fofanova T.V., Ageev F.T., Blankova Z.N., Vitsenya M.V., Tsybulsckaya T.V., Neverova E.F., Samsonova N.S. Comparison of efficacy and safety of losartan fixed combination with amlodipine or hydrochlorothiazide in hypertensive patients during heatwaves. Kardiologicheskii vestnik, 2017, vol. 12, no.2, pp. 30-39 (in Russian).

26. Smirnova M.D., Ageev F.T., Svirida O.N., Kuz'mina A.E., Galaninskii P.V., Shatalina L.S. Vliyanie povysheniya temperatury vozdukha na elektrolitnyi balans, gemodinamiku i kachestvo zhizni bol'nykh arterial'noi gipertoniei i vozmozhnost' profilakticheskogo ispol'zovaniya preparata Panangin [Influence exerted by temperature rise on electrolyte balance, hemodynamics, and life quality of people who suffer from primary hypertension; possible preventive effects produced by Panangin]. Russkii meditsinskii zhurnal. Meditsinskoe obozrenie, 2013, vol. 21, no. 3, pp. 159-164 (in Russian).

Shartova N.V., Shaposhnikov D.A., Konstantinov P.I., Revich B.A. Universal thermal climate index (utci) applied to determine thresholds for temperature-related mortality. Health Risk Analysis, 2019, no. 3, pp. 83-93. DOI: 10.21668/health.risk/2019.3.10.eng

Received: 13.08.2019

Accepted: 10.09 .2019

Published: 30.09.2019 
UDC 550.47

DOI: 10.21668/health.risk/2019.3.11.eng

\title{
ELEMENTAL MARKERS OF EXPOSURE UNDER COMBINED ORAL INTRODUCTION OF CHEMICAL MIXTURES WITH PREVALENT ANTIMONY AND ARSENIC INTO WHITE WISTAR RATS
}

\author{
S.Yu. Franovskii ${ }^{1}$, V.V. Turbinskii ${ }^{2}$, E.I. $\mathrm{Oks}^{3}$, S.B. Bortnikova ${ }^{4}$ \\ ${ }^{1}$ Moscow State University, 12 Bldg., 1 Leninskie Gory, Moscow, 119991, Russian Federation \\ ${ }^{2}$ Novosibirsk State Medical University, 52 Krasny Prospect, Novosibirsk, 630091, Russian Federation \\ ${ }^{3}$ Federal Service for Surveillance over Consumer Rights Protection and Human Well-being in the Kemerovo \\ Region, 24 Kuznetskii Av., Kemerovo, 650992, Russian Federation \\ ${ }^{4}$ Trofimuk Institute of Petroleum-Gas Geology and Geophysics of the Siberian Branch of the RAS, 3 Akademika \\ Koptyuga Av., Novosibirsk, 630090, Russian federation
}

The present paper dwells on assessing oral sub-acute exposure of a warm-blooded body to non-organic compounds that contain antimony and arsenic and are introduced with drinking water. Another issue was to assess changes in their concentrations as well as concentrations of other elements in tissues of certain organs. We accomplished elemental analysis of tissues taken from exposed white Wistar rats; the analysis included the following elements: $\mathrm{S}, \mathrm{Cl}, \mathrm{K}, \mathrm{Ca}, \mathrm{Ti}, \mathrm{Cr}, \mathrm{Mn}, \mathrm{Fe}, \mathrm{Ni}, \mathrm{Cu}, \mathrm{Zn}, \mathrm{Se}, \mathrm{Br}, \mathrm{Rb}, \mathrm{Sr}, \mathrm{Mo}$, As, $\mathrm{Hg}, \mathrm{Pb}$, Sb. As per its results we characterized changes in elemental structure of the liver, kidneys, heart, lungs, femoral muscle, thyroid gland, and whole blood caused in white male Wistar rats by sub-acute combined oral exposure to arsenic and antimony. Arsenic was detected in all the examined internal organs after 3 weeks of combined oral exposure to it in a dose equal to $15 \mu \mathrm{g} / \mathrm{kg}$ together with exposure to antimony in a dose equal to $61 \mu \mathrm{g} / \mathrm{kg}$. It concerned both test and control group as animals in the test group had arsenic in a dose equal to $0.010 \pm 0.002 \mu \mathrm{g} / \mathrm{kg}$ in the thyroid gland tissues and up to $0.950 \pm 0.155 \mu \mathrm{g} / \mathrm{kg}$ in blood; animals in the control group, from $0.028 \pm 0.003 \mu \mathrm{g} / \mathrm{kg}$ in muscular tissues to $1.56 \pm 0.03 \mu \mathrm{g} / \mathrm{kg}$ in blood. Antimony was detected in blood only $(0.005 \pm 0.0021 \mu \mathrm{g} / \mathrm{kg}$ in the control group and $0.021 \pm 0.0009 \mu \mathrm{g} / \mathrm{kg}$ in the test one).

We detected a direct correlation between arsenic contents in organ tissues and contents of potassium, iron, and mercury in the control group and contents of iron and mercury in the test one. Strontium and rubidium concentrations in organs of animals in the test group were inversely correlated with arsenic concentrations.

We analyzed a correlation between growing arsenic contents in tissues of animals in the test group against the control and changes in contents of other elements and revealed a statistically authentic correlation with an increase in concentrations of potassium, molybdenum, iron, and lead, as well as an inverse character of this correlation.

We concluded that there were several markers of oral exposure to arsenic and antimony as components in a complex mixture detected in white Wistar rats; they were arsenic in tissues of the liver, kidneys, muscles, thyroid gland, and whole blood; antimony in whole blood; increase in contents of chlorine, potassium, sulfur, calcium, rubidium, zinc, manganese, and chromium in the liver and kidneys; a decrease in concentrations of chromium, manganese, iron, copper, molybdenum, nickel, selenium, and strontium in blood, heart, thyroid gland, and lungs.

Key words: antimony, arsenic, water, elemental structure of white rats' organ tissues, markers of exposure, chemical mixtures, combined examination, oral exposure.

Abnormal contents of chemical elements in the atmosphere exert their impacts on regulation of live processes in a body; induce disorders in morphogenesis, metabolic processes and metabolic coherence; make enzymes less active; cause dysfunctions and endemic diseases. A range of chemicals concentrations between their upper and bottom limits in external and internal environment defines how well a body can regulate its chemical homeostasis [1,2].

Biogeochemical monitoring substantiates medical and preventive support for demographic, social, and industrial development of a society [3]. Regulatory systems of a body change within certain ranges under exposure to abnormal geochemical conditions and it is vital

(C) Franovskii S.Yu., Turbinskii V.V., Oks E.I., Bortnikova S.B., 2019

Sergei Yu. Franovskii - post-graduate student at the Pedology Faculty (e-mail: franovsky.sergey@gmail.com; tel.: +7 (903) 510-50-23; ORCID: https://orcid.org/0000-0003-2328-2613).

Viktor V. Turbinskii - Doctor of Medical Sciences, Associate Professor, Professor at the Hygiene and Ecology Department (e-mail: vvturbinski@mail.ru; tel.: +7 (913) 776-37-58; ORCID: https://orcid.org/0000-0001-7668-9234).

Evgenii I. Oks - Supervisor (e-mail: ocsenko@42.rospotrebnadzor.ru; tel.: +7 (3842) 36-73-15; ORCID: https://orcid.org/00000001-8108-3159).

Svetlana B. Bortnikova - Doctor of Geological and Mineralogical Sciences, Professor, Head of the Geoelectrochemical Laboratory (e-mail: BortnikovaSB@ipgg.sbras.ru; tel.: +7 (383) 363-91-95; ORCID: https://orcid.org/0000-0003-2395-7406). 
to determine these ranges when general and specific medical and prevention activities are implemented [4-6]. A key focus in implementing monitoring programs should be a choice on criteria that describe influence exerted by adverse environmental factors on a human body and responses it gives to such influence.

A significance this or that element can have for a body is determined by a role it plays in vital activities [7]: sulfur is a component in many proteins and hormones, liver cells use it to neutralize toxic metabolic products. Potassium is a constant component in all body cells and tissues; its greatest quantities can be found in cells of the liver, kidneys, skin, muscles, and nervous system as salts such as chlorides, phosphates, carbonates, and sulfates. Ionized potassium or potassium bound to proteins or other organic compounds regulates activity of certain enzymes, notably $\mathrm{K}+$-ATP-ase, acetyl kinase, and pyruvate phosphokinase; the element is regulated by mineral corticosteroids produced by the adrenal cortex [8]. Chlorine is found in a body as anions of salts (sodium, potassium, calcium, manganese and others) in all body fluids [9]. Calcium participates in bone tissue formation, provides contractile function of plain and skeletal muscles, and regulates functions of the heart [10]. Titanium is necessary for erythrocytes creation in the bone marrow; it influences immune system functioning, regulates cholesterol and carbamide (urea) contents in blood, and participates in many metabolic reactions [11]. Chromium is a component in the lowmolecular organic complex, tolerance factor to dextrose; it stimulates biosynthesis of glycogen and protein, and normalizes lipid metabolism as well [12]. Manganese is a part of multiple enzymes, such as phosphoglucomutase, enolase, mitochondrial superoxide dismutase, etc.; it activates phosphofructokinase, arginase, dipeptidase, and bone and alkaline phosphatase [13]. Iron is contained in hemoglobin and muscle hemoglobin and is also a component in respiratory enzymes that catalyze breathing processes in cells and tissues [14]. This chemical element is a part of more than 70 various enzymes and it explains significant influence exerted by it on body growth and development, tissue breathing, hemopoiesis, immune genesis, and other physiological processes. Nickel participates in structural organization and functioning of DNA, RNA, and proteins [15]. Copper catalyzes hemoglobin formation in blood and is a part of many key enzymes such as cytochromec-oxidase, tyrosinase, ascorbinase, etc. [16]. Zink can be found in more than 80 enzymes, the most significant ones being alcohol dehydrogenase, lactate dehydrogenase, glutamate dehydrogenase, carbonic anhydrase, DNA- and RNA-polymerase, carboxypeptidase, glyceraldehyde-3-phosphate dehydrogenase, and aldolase. Selenium participates in redox processes at the cellular level (dextrose metabolism, the Krebs cycle, potassium-sodium-calcium metabolism etc.) and is involved in activities of more than 100 enzymes that take part in metabolic products detoxication; it is a component in most hormones [17]. Bromine can be found in an adult body in blood, bone, and muscle tissues, and its concentrations are the highest in the kidneys, hypophysis, and thyroid gland [18]. Rubidium can substitute potassium and is its synergist [19]. Rubidium also accumulates in the intracellular fluid and can substitute equivalent amounts of potassium in various processes. Strontium is concentrated in bones and it partially substitutes calcium [20]. Strontium is basically excreted with urine and to a lesser extent with bile. Molybdenum is a component in prosthetic groups of enzymes including xanthine oxidase, aldehyde oxidase, xanthine dehydrogenase, and sulfite oxidase [21]. Arsenic is intensely accumulated when there is shortage of selenium and can make for deficiency of this microelement [22]. Excessive quantities of arsenic are accumulated in the thyroid gland and cause endemic goiter. Arsenic interacts with thiol protein groups, cysteine, glutathione, and lipoic acid. Antimony $(\mathrm{Sb})$ is similar to arsenic in its properties and is known to inhibit enzymes that participate in carbohydrate, fat, and protein metabolism [23, 24].

Therefore, a human body provides homeostasis involving a lot of elements that differ from each other conditionally; sulfur and strontium predominantly have structural roles; chlorine, potassium, rubidium, calcium, zinc, and selenium are predominantly enzyme-dependent; copper, titanium, chromium, manganese, iron, molybdenum, nickel, and bromine have apparent metabolic and antioxidant activities. Multi- 
functional properties of certain elements and their metabolic dependence determine a variety of responses to multiple exposures that can give grounds for revealing initial shifts in elemental homeostasis of a body. At the same time, combined exposure to several elements in hazardous concentrations makes it difficult to predict probable effects produced by it.

Our research goal was to experimentally substantiate elemental exposure markers for tissues of internal organs taken from experimental animals after combined oral exposure to arsenic and antimony that were introduced into them as a complex mixture contained in drinking water.

Our research tasks were:

1) to perform hygienic assessment of chemicals concentrations in sewage from a tailings dam of a gold mine;

2) to assess doses in which antimony and arsenic were introduced into experimental animals;

3) to analyze dynamics of antimony and arsenic concentrations in blood of experimental animals under sub-acute oral introduction;

4) to describe changes that occurred in elemental structure of the liver, kidneys, heart, muscles, and thyroid gland under combined subacute oral exposure to antimony and arsenic.

Research objects. In Komsomolskiy settlement located in Kemerovo region specific local conditions could make for penetration of sewage that contained antimony and arsenic from a tailings dam into underground waterbearing layers used for providing drinking water supply to population. Antimony and arsenic produce similar toxic effects on a warm-blooded body as they deactivate thiol protein groups, amino acids, and metals in enzyme systems; taking it into account, we performed an experiment with a model mixture that contained sewage from a gold mine. This mixture contained high concentrations of antimony and arsenic. The experiment was performed to predict changes in a body under combined oral exposure to arsenic and antimony. Animals from the control were given drinking water from centralized water supply systems in Novosibirsk.

We examined tissues of internal organs, notably the liver, kidneys, heart, lungs, muscles, and thyroid gland, as well as whole blood of white male Wistar rats with their body weight being equal to 280-340 grams; there were 2 groups, the test and the control, 6 animals in each.

\section{Data applied in the research:}

- results obtained via analyzing structure of a model complex mixture in water that contained arsenic and antimony;

- hygienic standards for chemical contents in water;

- results of determining elements concentrations in tissues of internal organs, namely the liver, kidneys, heart, lungs, muscles, thyroid gland, and whole blood of white male Wistar rats from the test and control groups.

Animals in the test group were given model drinking water with increased quantities of antimony and arsenic and we kept daily accounting of water quantities consumed by them. Animals from the control group were given drinking water taken from centralized water supply systems in Novosibirsk. We took samples of organs and tissues after animals had been autopsied. Prior to autopsy all animals were taken out of the experiment via intraperitoneal introduction of Nembutal in a dose equal to $4 \mathrm{mg} / 100 \mathrm{~g}$ of body weight.

We performed atomic absorption analysis with "Kvant-2A" atomic absorption spectrometer (Moscow, KORTEK) equipped with deuterium correction device with non-selective absorption and relevant hollow cathode lamps. Heavy metals in samples were determined in accordance with requirements fixed in conventional procedures. Lead $(\mathrm{Pb})$ was determined in "propane-air" flame. We applied standards samples with IAEA-SOIL-7, IAEA-336 (Lichen), SRM 1572 (CitrusLeaves), SRM 1575 (PineNeedles) structures as reference ones in both analysis procedures.

As a result, we determined elemental structures of internal organs taken from experimental animals; all the obtained data were statistically processed with calculating mean values and standard error of the mean, coefficients of variation, validity of discrepancies in dispersion, and average values of parameters in both groups as per Fischer and Student's tests. To do that, we used applied Excel software package. Discrepancies with their validity being $p \leq 0.05$ were considered to be statistically significant.

Research results. The model complex mixture contained in water consumed by animals in the test group was orally intro- 
duced into them via providing them with free access to standard drinking bowls; animals from the control group consumed drinking water from similar bowls. Therefore, to calculate doses of chemicals consumed by rats, we kept daily accounting of water consumption volumes. We analyzed water consumption during three weeks of the experiment and revealed that there were no statistically authentic discrepancies in water consumption between the test and the control groups taken both in $\mathrm{ml}$ per day and recalculated per $1 \mathrm{~kg}$ of animals' body weight a day $(\mathrm{p}>0.05)$. So, having free access to drinking water from automated water bowls, animals from both groups consumed it in similar quantities, $71.9 \pm 4.9 \mathrm{ml} / \mathrm{kg} /$ day in the test group, and
$65.6 \pm 4.4 \mathrm{ml} / \mathrm{kg} / \mathrm{day}$ in the control group, $(\mathrm{p}>0.05)$ (Table 1).

We took data on actual water consumption by animals from the test and control groups and concentrations of chemicals in consumed water and calculated average daily doses of chemicals introduced into animals from both groups with drinking water.

We revealed that animals from the test group consumed higher quantities of chemicals than animals from the control group; for example, doses of strontium were 1.1 times higher; doses of potassium, calcium, chromium, manganese, iron, copper, zinc, rubidium, molybdenum, and lead, 7.7 times higher; sulfur, 18.3 times higher; nickel, 26.3 times higher (Table 2).

Table 2

Summary table showing water consumption by white male Wistar rats from the test and control group; water was consumed from automated water bowls in cages

\begin{tabular}{|l|c|c|c|c|}
\hline \multicolumn{1}{|c|}{ Dates of experiment } & Test, ml/day & Control, ml/day & $t$ & $P$ \\
\hline March 04-10, 2018 & $122 \pm 9.6$ & $113 \pm 7.8$ & 0.06 & 0.9521 \\
\hline March 11-17, 2018 & $127 \pm 8.1$ & $105 \pm 5.9$ & 0.22 & 0.8289 \\
\hline March 18-25, 2018 & $125 \pm 7.8$ & $105 \pm 8.1$ & 0.16 & 0.8786 \\
\hline Total & $125 \pm 8.1$ & $108 \pm 7.2$ & 0.14 & 0.8936 \\
\hline Average body weight, $\Gamma$ & $289 \pm 14.5$ & $273.5 \pm 12.4$ & 0.04 & 0.9669 \\
\hline Water consumption, $\mathrm{ml} / \mathrm{kg}$ /day per 1 animal & $71.9 \pm 4.9$ & $65.6 \pm 4.4$ & 0.15 & 0.8867 \\
\hline
\end{tabular}

Table 3

Concentrations in water $(\mathrm{Ct}, \mathrm{Cc})$ and daily doses $(\mathrm{ADt}, \mathrm{ADc})$ of chemicals consumed by animals form the test and control groups

\begin{tabular}{|c|c|c|c|c|c|}
\hline \multirow{2}{*}{ Elements } & \multirow{2}{*}{$\begin{array}{c}\text { Hygienic standard } \\
\text { 2.1.5.1315-03, mg/dm }\end{array}$} & \multicolumn{2}{|c|}{ Control } & \multicolumn{2}{c|}{ Test } \\
\cline { 3 - 6 } & $\begin{array}{c}\mathrm{Cc}, \\
\mathrm{mg} / \mathrm{dm}^{3}\end{array}$ & $\begin{array}{c}\mathrm{ADc}, \\
\mathrm{mg} / \mathrm{kg} / \mathrm{day}\end{array}$ & $\begin{array}{c}\mathrm{Ct}, \\
\mathrm{mg} / \mathrm{dm}^{3}\end{array}$ & $\begin{array}{c}\mathrm{ADt} \\
\mathrm{mg} / \mathrm{kg} / \mathrm{day}\end{array}$ \\
\hline $\mathrm{Ca}$ & 130 physiological & 15 & 0,98 & 86 & 6,2 \\
\hline $\mathrm{Ti}$ & 0.1 overall & 0.002 & 0.0001 & 0.0053 & 0.0004 \\
\hline $\mathrm{Cr}$ & 0.05 c.T. & $<0.001$ & 0.00003 & 0.0012 & 0.0001 \\
\hline $\mathrm{Mn}$ & 0.1 organoleptic & 0.0068 & 0.0004 & 0.02 & 0.0014 \\
\hline $\mathrm{Fe}$ & 0.3 organoleptic & 0.1 & 0.006 & 0.35 & 0.025 \\
\hline $\mathrm{Ni}$ & 0.02 sanitary & $<0.001$ & 0.00003 & 0.012 & 0.0009 \\
\hline $\mathrm{Cu}$ & 1.0 sanitary & 0.01 & 0.0006 & 0.07 & 0.0050 \\
\hline $\mathrm{Zn}$ & 1.0 overall & 0.03 & 0.0019 & 0.042 & 0.0030 \\
\hline $\mathrm{Rb}$ & 0.1 sanitary & $<0.001$ & 0.00003 & 0.0021 & 0.0002 \\
\hline $\mathrm{Sr}$ & 7.0 sanitary & 0.3 & 0.01968 & 0.31 & 0.022 \\
\hline $\mathrm{Mo}$ & 0.07 sanitary & $<0.001$ & 0.00003 & 0.0016 & 0.0001 \\
\hline $\mathrm{As}$ & 0.01 sanitary & $<0.001$ & 0.00003 & $\mathbf{0 . 2 1}$ & $\mathbf{0 . 0 1 5}$ \\
\hline $\mathrm{Pb}$ & 0.01 sanitary & $<0.001$ & 0.00003 & 0.001 & 0.0001 \\
\hline $\mathrm{Sb}$ & 0.005 sanitary & $<0.008$ & 0.0002 & $\mathbf{0 . 8 5}$ & $\mathbf{0 . 0 6 1}$ \\
\hline
\end{tabular}

Note: * means as fixed in section 4.7 of the Sanitary-Epidemiologic Rules 2.1.4.1116-02. Drinking water. Hygienic requirement to quality of bottled water. Quality control. 
Antimony and arsenic were orally introduced into animals from the test group in doses that were equal to $0.061 \mathrm{mg} / \mathrm{kg} /$ day and $0.015 \mathrm{mg} / \mathrm{kg} /$ day respectively; deviations from the hygienic standards were the highest for these two metals as their doses exceeded MPC by 605 times for antimony and by 500 times for arsenic.

We analyzed chemicals contents in tissues of organs taken from experimental animals after a three-week experiment and detected arsenic in all internal organs of animals form both groups, its quantities in the control group being from $0.010 \pm 0.002 \mu \mathrm{g} / \mathrm{g}$ in thyroid gland tissues to $0.950 \pm 0.155 \mu \mathrm{g} / \mathrm{g}$ in blood; from $0.028 \pm$ $\pm 0.003 \mu \mathrm{g} / \mathrm{g}$ in muscle tissues to $1.56 \pm 0.03 \mu \mathrm{g} / \mathrm{g}$ in blood in the test group (Table 3).

Antimony was detected in blood only, $0.005 \pm 0.0021 \mu \mathrm{g} / \mathrm{kg}$ in the control group and $0.021 \pm 0.0009 \mu \mathrm{g} / \mathrm{kg}$ in the test group.

Although animals from the test group consumed other elements that were included into the complex mixture in concentrations not exceeding MPC but being higher than those consumed by the control group, concentrations of such elements in tissues of their internal organs were still statistically authentically different from those taken out of animals from the control group.

We detected higher concentrations of some elements in blood of animals from the test group against the control group; these higher concentrations were detected for arsenic (on average by $64 \%$, with scaled-down dispersion $(\mathrm{pF}<0.05)$ ); antimony (on average by $320 \%$ $(\mathrm{p}<0.05)$; chlorides (by $110 \%, p<0.05)$ ), calcium (by $52 \%, \mathrm{p}<0.05$ ). We also detected lower concentrations of such elements as chromium (by $43 \%, p<0.05$ ); manganese (by $42 \%$, $\mathrm{p}<0.05$ ); molybdenum (by 75\%, $\mathrm{p}<0.05$ ); lead (by $36 \%, \mathrm{p}<0.05$ ); we also detected scaleddown dispersion for contents of iron, nickel, and copper $(\mathrm{pF}<0.05)$ with a $30-56 \%$ descending trend for their average values.

There was a decrease in dispersion of arsenic contents in liver tissues taken out of animals from the test group against the control group $(\mathrm{pF}<0,05)$ with a simultaneous trend for a $46 \%$ increase in its average value; liver tissues of animals from the test group also contained increased concentrations of chlorides (by $120 \%$ higher, $\mathrm{p}<0.05$ ); potassium (by 309\%, $\mathrm{p}<0.05$ ); calcium and chromium (by 2 times, $\mathrm{p}<0.05$ ); bromine (by $32 \%, \mathrm{p}<0.05$ ); rubidium (by $31 \%$, $\mathrm{p}<0.05)$; there was also a decrease in dispersion of copper contents $(\mathrm{pF}<0.05)$, with a trend for decrease in its average value by $20 \%$.

Kidney tissues taken out of animals from the test group contained arsenic in higher concentrations as compared with the control (by $102 \%, \mathrm{p}<0.05$ ); they also contained higher concentrations of manganese (by $14 \%, p<0.05$ ) and bromine (by $20 \%, p<0.05$ ), and there was a decrease in dispersion of potassium contents $(\mathrm{pF}<0.05)$ with a trend for a $364 \%$ increase in its average value. We detected an increase in dispersion of sulfur, chlorides, calcium, and zinc contents in the test group against the control one $(\mathrm{pF}<0.05)$ with a trend for a $47-364 \%$ increase in their average values.

Heart tissues taken out of animals from the test group contained arsenic in higher concentrations against the control (by $212 \%, \mathrm{pF}<0.05$ ); we also detected lower average molybdenum contents (by $38 \%, p<0.05$ ) and a trend for lower contents of nickel (by $88 \%, \mathrm{pF}<0.05$ ) and copper (by $22 \%, \mathrm{pF}<0.05$ ) as well as a trend for increased contents of chlorides (by 431\%, $\mathrm{pF}<0.05$ ), potassium (by $255 \%, \mathrm{pF}<0.05$ ), and selenium (by $50 \%, \mathrm{pF}<0.05$ ).

There were no statistically authentic discrepancies in arsenic contents in lung tissues between the test and control groups $(p>0.05)$, but still we detected increased potassium contents (by $134 \%, p<0.05$ ), a trend for higher bromine contents with increased dispersion of the parameter (by 28\%, $\mathrm{pF}<0.05$ ), a trend for higher lead contents with increased dispersion of the parameter (by $70 \%, \mathrm{pF}<0.05$ ) and lower contents of iron (by $33 \%, \mathrm{p}<0.05$ ), zinc (by $18 \%$, $\mathrm{p}<0.05$ ), and molybdenum (by $24 \%, \mathrm{p}<0.05$ ).

Tissues of thigh muscle taken out of animals from the test group contained some elements in higher concentrations as compared with the control group; these elements were arsenic (by $55 \%, \mathrm{p}<0.05$ ), sulfur (by $13 \%$, $\mathrm{p}<0.05$ ), calcium (by $31 \%, \mathrm{p}<0.05$ ), strontium (by $125 \%, \mathrm{p}<0.05$ ), and lead (by $85 \%, \mathrm{p}<0.05$ ). We detected a trend for higher concentrations with simultaneous decrease in dispersion of the parameter for potassium contents (by $400 \%$, $\mathrm{pF}<0.05$ ), and a trend for a decrease in the parameter together with a decrease in its dispersion was detected for nickel (by $53 \%, \mathrm{pF}<0.05$ ). 
Table 3

Elements concentrations in tissues of internal organs $(\mu \mathrm{g} / \mathrm{g})$ taken out of male white Wistar rats after 3 weeks of daily oral exposure to arsenic in a dose equal to $15 \mu \mathrm{g} / \mathrm{kg} /$ day and antimony in a dose equal to $61 \mu \mathrm{g} / \mathrm{kg} / \mathrm{day}$, both metals were contained in sewage from a tailings dam of Komsomolskiy gold mine

\begin{tabular}{|c|c|c|c|c|c|c|c|c|c|c|c|c|c|c|c|c|c|c|c|c|}
\hline \multirow{2}{*}{\begin{tabular}{|c|} 
Groups, \\
statistical \\
parameter
\end{tabular}} & \multicolumn{20}{|c|}{ Chemical elements/organs } \\
\hline & $\mathrm{S}$ & $\mathrm{Cl}$ & $\mathrm{K}$ & $\mathrm{Ca}$ & $\mathrm{Ti}$ & $\mathrm{Cr}$ & $\mathrm{Mn}$ & $\mathrm{Fe}$ & $\mathrm{Ni}$ & $\mathrm{Cu}$ & $\mathrm{Zn}$ & $\mathrm{Se}$ & $\mathrm{Br}$ & $\mathrm{Rb}$ & $\mathrm{Sr}$ & Mo & As & $\mathrm{Hg}$ & $\mathrm{Pb}$ & $\mathrm{Sb}$ \\
\hline & \multicolumn{20}{|c|}{ Blood } \\
\hline Control, X & 808 & 229 & 7,639 & 14.7 & 0.58 & 67 & 5.26 & 236.2 & 0.121 & 0.392 & 31.5 & 0.19 & 0.96 & 0.10 & 0.223 & 1.32 & 0.95 & 0.026 & 0.115 & 0.00 \\
\hline $\mathrm{m}$ & 141 & 125 & 981 & 1.2 & 0.07 & 0.14 & \begin{tabular}{|l|}
0.26 \\
\end{tabular} & \begin{tabular}{|l|}
15.7 \\
\end{tabular} & 0.015 & \begin{tabular}{|l|}
0.046 \\
\end{tabular} & 1.2 & 0.01 & 0.04 & \begin{tabular}{|l|}
0.01 \\
\end{tabular} & 0.018 & 0.07 & 0.155 & 0.0009 & 0.0068 & 00021 \\
\hline V\% & $7 \%$ & $25 \%$ & $31 \%$ & $20 \%$ & $28 \%$ & $21 \%$ & \begin{tabular}{|l|}
$12 \%$ \\
\end{tabular} & $16 \%$ & $31 \%$ & $29 \%$ & $9 \%$ & $12 \%$ & $10 \%$ & $14 \%$ & $20 \%$ & $13 \%$ & $40 \%$ & $8 \%$ & $15 \%$ & $03^{\circ}$ \\
\hline Test, $X$ & 4,283 & 2,601 & 6,614 & \begin{tabular}{|l|}
22.5 \\
\end{tabular} & \begin{tabular}{|l|}
0.40 \\
\end{tabular} & 0.96 & \begin{tabular}{|l|}
3.07 \\
\end{tabular} & \begin{tabular}{|l|}
164.8 \\
\end{tabular} & 0.054 & 0.293 & 30.9 & 0.183 & 30.92 & \begin{tabular}{|l|}
0.11 \\
\end{tabular} & 0.215 & \begin{tabular}{|l|}
0.34 \\
\end{tabular} & 1.56 & 0.025 & 0.074 & 0.021 \\
\hline$\pm \mathrm{m}$ & 206 & 255 & 406 & 0.9 & 0.05 & 0.07 & \begin{tabular}{|l|}
0.31 \\
\end{tabular} & 3.5 & 0.005 & \begin{tabular}{|l|}
0.004 \\
\end{tabular} & 0.96 & 0.007 & 7) 0.05 & 0.01 & 0.016 & 0.04 & 0.03 & \begin{tabular}{l|}
0.002 \\
\end{tabular} & 0.004 & $\overline{0009}$ \\
\hline V\% & $12 \%$ & $24 \%$ & $15 \%$ & $10 \%$ & $29 \%$ & \begin{tabular}{|l|}
$18 \%$ \\
\end{tabular} & $25 \%$ & $5 \%$ & $23 \%$ & $4 \%$ & $8 \%$ & $9 \%$ & $15 \%$ & $15 \%$ & $18 \%$ & $26 \%$ & $5 \%$ & $15 \%$ & $14 \%$ & $11 \%$ \\
\hline $\mathrm{D}$ & 0.0801 & 0.0029 & 90.3715 & 0.0019 & 0.0661 & 0.0040 & 0.0016 & 0.004 & 0.0059 & 0.0767 & 0.6810 & 0.657 & 0.544 & 0.1732 & 20.7670 & 0.0000 & $\begin{array}{ll}0 & 0.0086 \\
\end{array}$ & \begin{tabular}{|l|l|}
6 & 0.5037 \\
\end{tabular} & 0.0022 & 0.0004 \\
\hline \multirow[t]{2}{*}{$\mathrm{pF}$} & 0.2417 & 0.0990 & 0.0577 & 0.2834 & 0.2739 & 0.1078 & 0.3755 & 0.0068 & 0.0272 & 0.0002 & 0.3451 & 10.317 & 70.273 & 0.3501 & 10.4063 & 0.1233 & 30.0 & \begin{tabular}{|l|l|}
7 & 0.8460 \\
\end{tabular} & 0.1996 & .0750 \\
\hline & \multicolumn{20}{|c|}{ Liver } \\
\hline Control, X & 2,772 & 378 & 1,373 & \begin{tabular}{|l|}
14.73 \\
\end{tabular} & 0.21 & 0.26 & \begin{tabular}{|l|}
5.59 \\
\end{tabular} & \begin{tabular}{|l|}
30.02 \\
\end{tabular} & 0.064 & 1.3 & \begin{tabular}{|l|}
84.3 \\
\end{tabular} & 0.270 & 0.317 & \begin{tabular}{|l|}
0.189 \\
\end{tabular} & 0.112 & 2.565 & 0.037 & .0007 & 0.059 & \\
\hline$m$ & 297 & 96 & 390 & 2.26 & 0.07 & \begin{tabular}{|l|}
0.009 \\
\end{tabular} & \begin{tabular}{|l|}
0.27 \\
\end{tabular} & 1.25 & 0.021 & \begin{tabular}{|l|}
0.091 \\
\end{tabular} & 2.0 & 0.025 & 50.033 & \begin{tabular}{|l|}
0.018 \\
\end{tabular} & 0.008 & 0.030 & 0.006 & \begin{tabular}{|l|l|}
5 & 0.0001 \\
\end{tabular} & 0.009 & \\
\hline$\%$ & $26 \%$ & $62 \%$ & $70 \%$ & $38 \%$ & $81 \%$ & $9 \%$ & $12 \%$ & $10 \%$ & \begin{tabular}{|l|}
$79 \%$ \\
\end{tabular} & $17 \%$ & $6 \%$ & $22 \%$ & $26 \%$ & $23 \%$ & & $3 \%$ & & $35 \%$ & & \\
\hline Test, $\mathrm{X}$ & 3,312 & 848 & 5,688 & \begin{tabular}{|l|}
28.7 \\
\end{tabular} & 1.19 & 0.53 & \begin{tabular}{|l|}
6.06 \\
\end{tabular} & 29.03 & 0.087 & 1.1 & \begin{tabular}{|l|l|}
86.7 \\
\end{tabular} & 0.249 & 9.414 & 0.25 & 0.295 & 2.7 & 0.054 & \begin{tabular}{|l|l} 
\\
\end{tabular} & \begin{tabular}{|l|} 
\\
\end{tabular} & \\
\hline $\mathrm{m}$ & 115 & 102.1 & 421 & 3.6 & 0.57 & 0.09 & \begin{tabular}{|l|}
0.42 \\
\end{tabular} & \begin{tabular}{|l|}
2.05 \\
\end{tabular} & 0.028 & \begin{tabular}{|l|}
0.043 \\
\end{tabular} & 2.4 & 0.018 & 80.018 & 0.012 & 0.040 & 0.1 & 0.003 & 0.0002 & 0.030 & \\
\hline V\% & $9 \%$ & $30 \%$ & $18 \%$ & $31 \%$ & $118 \%$ & $45 \%$ & \begin{tabular}{|l|}
$17 \%$ \\
\end{tabular} & $17 \%$ & \begin{tabular}{|l|l|}
$81 \%$ \\
\end{tabular} & $10 \%$ & $7 \%$ & $17 \%$ & $11 \%$ & \begin{tabular}{|l|}
$12 \%$ \\
\end{tabular} & $33 \%$ & $9 \%$ & $\%$ & $54 \%$ & $56 \%$ & \\
\hline$P$ & 0.1415 & 0.0151 & 10.0002 & 0.0169 & 0.1402 & 0.0317 & \begin{tabular}{|l|}
0.38 \\
\end{tabular} & \begin{tabular}{|l|}
0.69 \\
\end{tabular} & 0.5426 & 0.0508 & 0.4763 & 30.521 & $\mid 0.044$ & 0.0333 & 30.0042 & 0.1465 & 0.0410 & $\begin{array}{lll}0 & 0.4055 \\
\end{array}$ & 0.0634 & \\
\hline \multirow[t]{2}{*}{$\mathrm{pF}$} & \begin{tabular}{|l|}
0.018 \\
\end{tabular} & 0.44 & 0.4294 & \begin{tabular}{|l|l|}
0.14 \\
\end{tabular} & 0.0001 & |9E-06 & 0.153 & 0.129 & 0.2226 & 0.0473 & 0.3512 & 20.222 & 20.086 & 0.2044 & 40.0006 & 0.0040 & $\begin{array}{ll}0 & 0.0383 \\
\end{array}$ & \begin{tabular}{|l|l|}
3 & 0.0579 \\
\end{tabular} & 0.005 & \\
\hline & & & & & & & & & & Kidn & & & & & & & & & & \\
\hline Cont & 098 & 872 & 1,181 & \begin{tabular}{|l|}
26.4 \\
\end{tabular} & 0.26 & 0.49 & .14 & 8.8 & 078 & 2.1 & 73.5 & 0.58 & 0.80 & 0.14 & .235 & 1.94 & 17 & 5-05 & 0.101 & \\
\hline$\pm \mathrm{m}$ & 33 & 63 & 145 & \begin{tabular}{|l|}
0.91 \\
\end{tabular} & \begin{tabular}{|l|}
0.04 \\
\end{tabular} & 0.06 & \begin{tabular}{|l|}
0.13 \\
\end{tabular} & \begin{tabular}{|l|}
0.62 \\
\end{tabular} & 0.0059 & 0.080 & 0.194 & 0.031 & 0.017 & 0.003 & 0.022 & 0.026 & 0.005 & 0.00001 & 10.003 & \\
\hline V\% & $3 \%$ & $18 \%$ & $30 \%$ & $8 \%$ & $38 \%$ & $30 \%$ & \begin{tabular}{|l|}
$10 \%$ \\
\end{tabular} & $8 \%$ & $18 \%$ & $9 \%$ & $1 \%$ & $13 \%$ & $5 \%$ & $5 \%$ & $23 \%$ & $3 \%$ & $72 \%$ & $72 \%$ & $9 \%$ & \\
\hline Test, & 4,565 & 2,134 & 5,487 & \begin{tabular}{|l|}
42.0 \\
\end{tabular} & \begin{tabular}{|l|}
0.34 \\
\end{tabular} & 0.42 & \begin{tabular}{|l|}
3.57 \\
\end{tabular} & 19.15 & 0.093 & 2.07 & \begin{tabular}{|l|}
83.0 \\
\end{tabular} & 0.657 & 0.96 & 0.18 & 0.3425 & 1.8825 & 36 & .00008 & 0. & \\
\hline$\pm \mathrm{m}$ & 249 & 253 & 317 & 4.5 & \begin{tabular}{|l|}
0.10 \\
\end{tabular} & 0.05 & \begin{tabular}{|l|}
0.11 \\
\end{tabular} & \begin{tabular}{|l|}
0.92 \\
\end{tabular} & \begin{tabular}{|l|}
0.03 \\
\end{tabular} & 0.23 & \begin{tabular}{|l|}
3.41 \\
\end{tabular} & 0.07 & \begin{tabular}{|l|} 
\\
\end{tabular} & 0.01 & 0.04 & \begin{tabular}{|l|}
0.19 \\
\end{tabular} & 0.004 & 0.00002 & \begin{tabular}{|l|l|}
2 & 0.04 \\
\end{tabular} & \\
\hline $\mathrm{V} \%$ & $13 \%$ & $29 \%$ & $14 \%$ & $26 \%$ & $71 \%$ & $30 \%$ & \begin{tabular}{|l|}
$8 \%$ \\
\end{tabular} & $12 \%$ & $75 \%$ & $27 \%$ & $10 \%$ & $27 \%$ & $7 \%$ & $11 \%$ & $30 \%$ & $25 \%$ & $27 \%$ & $64 \%$ & $59 \%$ & \\
\hline & 0.0011 & 0.0028 & $2 \mathrm{E}-05$ & 0.0151 & \begin{tabular}{|c|}
0.4787 \\
\end{tabular} & 0.4272 & 0.0485 & \begin{tabular}{|l|}
0.8177 \\
\end{tabular} & 0.64 & 0.83 & \begin{tabular}{|l|}
0.03 \\
\end{tabular} & 0.35 & 0.00 & \begin{tabular}{|l|}
0.00 \\
\end{tabular} & 0.06 & 0.78 & & 0.26 & & \\
\hline $\mathrm{pF}$ & 0.0001 & 0.0019 & 90.0394 & 0.000 & 0.0245 & 0.348 & 0.3926 & 0.1778 & 00007 & 0.0103 & 0.0001 & 10.031 & 0.123 & 0.01 & 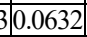 & 0.0001 & 109 & 0.1868 & & \\
\hline & & & & & & & & & & $\mathrm{Hec}$ & & & & & & & & & & \\
\hline Con & $5,171.6$ & 280 & $2,120.4$ & 33.2 & 0.4674 & 0.78 & 2.33 & 35.6 & 0.086 & 1.842 & \begin{tabular}{|l|}
59.54 \\
\end{tabular} & 0.125 & 50. & \begin{tabular}{|l|}
0.104 \\
\end{tabular} & 0.228 & 0.688 & 0.079 & 0002 & 0.079 & \\
\hline$\pm \mathrm{m}$ & 182 & 39 & 276 & \begin{tabular}{|l|}
0.60 \\
\end{tabular} & \begin{tabular}{|l|}
0.042 \\
\end{tabular} & \begin{tabular}{|l|}
0.029 \\
\end{tabular} & \begin{tabular}{|l|}
0.067 \\
\end{tabular} & 1.2 & 0.006 & \begin{tabular}{|l|}
0.057 \\
\end{tabular} & 0.352 & 0.001 & 0.029 & \begin{tabular}{|l|}
0.007 \\
\end{tabular} & 0.004 & \begin{tabular}{|l|}
0.034 \\
\end{tabular} & 0.009 & 0.0001 & \begin{tabular}{|l|}
0.002 \\
\end{tabular} & \\
\hline $\mathrm{V} \%$ & $9 \%$ & $34 \%$ & $32 \%$ & \begin{tabular}{|l|}
$4 \%$ \\
\end{tabular} & \begin{tabular}{|l|}
$22 \%$ \\
\end{tabular} & $9 \%$ & \begin{tabular}{|l|}
$7 \%$ \\
\end{tabular} & $8 \%$ & $17 \%$ & $8 \%$ & $1 \%$ & $3 \%$ & $18 \%$ & \begin{tabular}{|l|}
$17 \%$ \\
\end{tabular} & $4 \%$ & \begin{tabular}{|l|l|}
$12 \%$ \\
\end{tabular} & $28 \%$ & $83 \%$ & $6 \%$ & \\
\hline Test, & \begin{tabular}{|l|l|}
5,859 \\
\end{tabular} & 1,488 & 7,529 & \begin{tabular}{|l|}
31.4 \\
\end{tabular} & 0.31 & 0.36 & \begin{tabular}{|l|}
1.99 \\
\end{tabular} & 37.65 & 0.066 & 1.41 & 64 & 0.185 & 50.78 & \begin{tabular}{|l|}
0.173 \\
\end{tabular} & \begin{tabular}{|l|}
0.273 \\
\end{tabular} & 35 & \begin{tabular}{|l|}
0.249 \\
\end{tabular} & 01 & \begin{tabular}{|l|}
0.073 \\
\end{tabular} & \\
\hline$\pm \mathrm{m}$ & 426 & 113 & 1034 & 3.9 & \begin{tabular}{|l|l|}
0.07 \\
\end{tabular} & \begin{tabular}{|l|l|}
0.09 \\
\end{tabular} & 0.2 & 6.0 & 0.010 & 0.17 & 2.261 & 0.020 & 0.16 & \begin{tabular}{|l|}
0.016 \\
\end{tabular} & \begin{tabular}{|l|}
0.020 \\
\end{tabular} & \begin{tabular}{|l|}
0.040 \\
\end{tabular} & 0.073 & 0.0002 & 0. & \\
\hline V\% & $18 \%$ & $19 \%$ & $34 \%$ & $31 \%$ & $57 \%$ & \begin{tabular}{|l|}
$58 \%$ \\
\end{tabular} & $25 \%$ & $39 \%$ & $37 \%$ & $29 \%$ & $9 \%$ & $27 \%$ & $51 \%$ & \begin{tabular}{|l|}
$22 \%$ \\
\end{tabular} & $18 \%$ & $22 \%$ & $\%$ & $84 \%$ & 15 & \\
\hline $\mathrm{P}$ & 0.1888 & 0.0001 & \begin{tabular}{l|l} 
& 0.0023 \\
\end{tabular} & 0.6572 & 0.1032 & 0.0035 & 0.1583 & 0.7555 & \begin{tabular}{|l|}
0.1399 \\
\end{tabular} & 0.0496 & 0.0992 & 20.026 & 60.062 & 0.0080 & 0.0682 & 0.0028 & & \begin{tabular}{|l|l|}
0 & 0.1560 \\
\end{tabular} & & \\
\hline $\mathrm{pF}$ & 0.02 & 0.0101 & 10.0027 & 0.0001 & $\mid 0.1072$ & 0.009 & 0.00 & 0.000 & 0.128 & 0.0093 & 0.0001 & 10.000 & 0.001 & 0.0 & 50.0 & 0.3 & & $\overline{000}$ & 0.0 & \\
\hline & & & & & & & & & & Lun & & & & & & & & & & \\
\hline Conts & 4,143 & 067 & 553 & \begin{tabular}{|l|}
41.4 \\
\end{tabular} & 0.44 & 1.6 & 2. & \begin{tabular}{|l|}
44.6 \\
\end{tabular} & 0.1 & 1.47 & 89 & 0.18 & 1.07 & .14 & 0.39 & 0.78 & 11 & 0.001 & \begin{tabular}{|l|}
0.098 \\
\end{tabular} & \\
\hline $\mathrm{m}$ & & 40 & 510 & $13^{3}$ & 0. & $\overline{0.0}$ & 0 & 36 & 0.008 & \begin{tabular}{|l|}
0.081 \\
\end{tabular} & 3.9 & 0.006 & 60.061 & \begin{tabular}{|l|}
0.012 \\
\end{tabular} & 0.014 & 0 & 23 & & 0.006 & \\
\hline V\% & $5 \%$ & $32 \%$ & $49 \%$ & $8 \%$ & $39 \%$ & $5 \%$ & \begin{tabular}{|l|}
$11 \%$ \\
\end{tabular} & $20 \%$ & $19 \%$ & $13 \%$ & \begin{tabular}{|l|}
$11 \%$ \\
\end{tabular} & $8 \%$ & $14 \%$ & $21 \%$ & $9 \%$ & $12 \%$ & $49 \%$ & $122 \%$ & $16 \%$ & \\
\hline Test, & 4,606 & 2,604 & 5,979 & \begin{tabular}{|l|}
49.7 \\
\end{tabular} & \begin{tabular}{|l|l|}
0.60 \\
\end{tabular} & 1.15 & \begin{tabular}{|l|}
2.05 \\
\end{tabular} & \begin{tabular}{|l|}
31.7 \\
\end{tabular} & 0.092 & 0.928 & 73.75 & 0.176 & 1.081 & 0.1765 & 0.3575 & 0.60 & 0.18375 & 50.0004 & 0.170 & \\
\hline 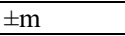 & & 739 & 576 & 5.8 & \begin{tabular}{|l|l|}
0.07 \\
\end{tabular} & 0.31 & 0 & 3.6 & 0.025 & \begin{tabular}{|l|}
0.245 \\
\end{tabular} & 2.686 & 0.002 & & \begin{tabular}{|l|}
0.010 \\
\end{tabular} & \begin{tabular}{|l|}
0.054 \\
\end{tabular} & \begin{tabular}{|l|}
0.027 \\
\end{tabular} & & & & \\
\hline $\mathrm{V}^{0}$ & 70 & \begin{tabular}{ll|}
$69 \%$ \\
\end{tabular} & $24 \%$ & $29 \%$ & $31 \%$ & \begin{tabular}{|l|l|}
$67 \%$ \\
\end{tabular} & $22 \%$ & $27 \%$ & \begin{tabular}{|l|}
$67 \%$ \\
\end{tabular} & $65 \%$ & $9 \%$ & $3 \%$ & $\%$ & \begin{tabular}{|l|l|}
$14 \%$ \\
\end{tabular} & $37 \%$ & $11 \%$ & $\%$ & $163 \%$ & $34 \%$ & \\
\hline $\mathrm{P}$ & \begin{tabular}{|l|}
0.189 \\
\end{tabular} & 0.0868 & 80.0043 & 0.2114 & 0.9824 & 0.2176 & 0.1174 & 0.0446 & 0.7566 & 0.0794 & 0.0184 & 40.250 & 0.947 & 0.05 & 0.5427 & 0.0098 & 80.0931 & \begin{tabular}{|l|l|}
1 & 0.3304 \\
\end{tabular} & 0.0252 & \\
\hline $\mathrm{pF}$ & 0.0175 & 0.0034 & 40.4093 & 0.0063 & 0.4469 & 0.0004 & 0.1256 & 0.514 & 0.005 & \begin{tabular}{|l|} 
\\
\end{tabular} & \begin{tabular}{|l|}
0.190 \\
\end{tabular} & 0.043 & $\mid 0.033$ & 0.31 & 0.002 & \begin{tabular}{|l|} 
\\
\end{tabular} & \begin{tabular}{|l|l|}
0.376 \\
\end{tabular} & $50.0757 \mid$ & 0.0032 & \\
\hline & & & & & & & & & & & & & & & & & & & & \\
\hline Control, X & 3,980 & 134 & 1,822 & 25 & 0.28 & 2.13 & \begin{tabular}{|l|}
3.37 \\
\end{tabular} & \begin{tabular}{|l|}
19.8 \\
\end{tabular} & 45 & 0.413 & \begin{tabular}{|l|}
32.5 \\
\end{tabular} & 0.063 & 0.182 & 0.1675 & \begin{tabular}{|l|l|}
50.16 \\
\end{tabular} & 0.26 & 18 & 02 & 0.045 & \\
\hline$+m$ & 106 & 15 & 211 & 1.7 & 0.04 & 0.12 & 0. & \begin{tabular}{|l|}
0.96 \\
\end{tabular} & 0.016 & 0.025 & 6.3 & 0.001 & 0.0 & 0.012 & 0.060 & 0.016 & 03 & 0.0 & 30.003 & \\
\hline V\% & & $27 \%$ & & $17 \%$ & $37 \%$ & $14 \%$ & & $12 \%$ & $27 \%$ & $15 \%$ & \begin{tabular}{|l|l|}
$48 \%$ \\
\end{tabular} & $2 \%$ & & $17 \%$ & & & & & & \\
\hline Test, & 4,508 & 841 & 24 & 32.6 & 0.37 & 0 & 0. & 6.42 & & 6 & \begin{tabular}{|l|}
48.9 \\
\end{tabular} & 0.07 & 0 & \begin{tabular}{|l|}
0.19 \\
\end{tabular} & & 22 & 28 & & & \\
\hline$\pm \mathrm{m}$ & 112 & 141 & 708 & \begin{tabular}{|l|}
1.21 \\
\end{tabular} & \begin{tabular}{|l|l|}
0.03 \\
\end{tabular} & 0.11 & \begin{tabular}{|l|}
0.21 \\
\end{tabular} & 0.456 & 0.004 & 0.016 & 14.3 & 0.009 & 0.075 & 0.021 & 0.042 & \begin{tabular}{|l|}
0.011 \\
\end{tabular} & \begin{tabular}{|l|l|}
0.003 \\
\end{tabular} & 0.00004 & 40.004 & \\
\hline V\% & $0 / 0$ & $41 \%$ & $19 \%$ & $9 \%$ & $20 \%$ & $46 \%$ & $56 \%$ & $17 \%$ & $14 \%$ & $11 \%$ & $71 \%$ & $31 \%$ & & $27 \%$ & $29 \%$ & $12 \%$ & & & & \\
\hline 1 & 2012 & 0.0024 & $7 \mathrm{E}-05$ & 0.0109 & 0.1298 & 0.0000 & 0.0010 & 0.0001 & 0.0035 & 0.1380 & 0.3343 & & & & 0.0346 & 0.1043 & & \begin{tabular}{l|l}
9 & 0.1 \\
\end{tabular} & & \\
\hline $\mathrm{pF}$ & - & 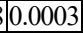 & 20010 & .25 & 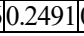 & 18 & 17 & $\operatorname{los}_{0}$ & & 0.1981 & 0.0731 & 10.001 & 10.01 & 0.14 & 7 & 261 & 0.3662 & 2 & $T 0$ & \\
\hline & & & & & & & & & & & & & & & & & & & & \\
\hline t & 5,346 & 314 & 718 & 50.3 & 0 & 1.0 & & 13 & & & \begin{tabular}{|l|}
50.28 \\
\end{tabular} & & & & & & & & & \\
\hline$\pm \mathrm{m}$ & 263 & 21 & 363 & 4.1 & 0.1 & 0.1 & \begin{tabular}{|l|}
0.2 \\
\end{tabular} & 2.2 & 0.023 & 0.074 & 1.6 & 0.005 & 0.036 & 0.011 & 0.020 & 0.073 & 0.002 & \begin{tabular}{|l|l|}
2 & 0.0005 \\
\end{tabular} & 0.003 & \\
\hline $\mathrm{V} \%$ & $12 \%$ & $16 \%$ & $24 \%$ & $20 \%$ & $34 \%$ & \begin{tabular}{|l|}
$29 \%$ \\
\end{tabular} & $26 \%$ & \begin{tabular}{|l|}
$41 \%$ \\
\end{tabular} & \begin{tabular}{|l|}
$19 \%$ \\
\end{tabular} & $26 \%$ & $8 \%$ & $14 \%$ & $26 \%$ & \begin{tabular}{|l|}
$19 \%$ \\
\end{tabular} & $12 \%$ & \begin{tabular}{|l|}
$34 \%$ \\
\end{tabular} & $39 \%$ & $82 \%$ & $7 \%$ & \\
\hline & 3,260 & 1,880 & 9,424 & 41.1 & 0.5 & 0.5 & 1. & 13.7 & 0.128 & 0.493 & \begin{tabular}{|l|l|}
67.1 \\
\end{tabular} & 0.111 & 10.65 & \begin{tabular}{|l|}
0.204 \\
\end{tabular} & 0.34 & 0.46 & 0.060 & 0.0018 & & \\
\hline$\pm \mathrm{m}$ & 106 & 175 & 355 & 4.9 & 0.1 & \begin{tabular}{|l|l|}
0.04 \\
\end{tabular} & 0.2 & \begin{tabular}{|l|}
0.72 \\
\end{tabular} & 0.024 & 0.026 & 3.1 & 0.006 & 6 0.04 & 0.007 & 0.03 & 0.02 & 0.008 & \begin{tabular}{|l|l|}
0.0006 \\
\end{tabular} & 0.030 & \\
\hline $\mathrm{V}^{0}$ & $8 \%$ & $23 \%$ & $9 \%$ & $29 \%$ & $39 \%$ & $20 \%$ & \begin{tabular}{|l|}
$28 \%$ \\
\end{tabular} & $13 \%$ & $47 \%$ & $13 \%$ & \begin{tabular}{|l|}
$11 \%$ \\
\end{tabular} & $13 \%$ & $16 \%$ & $8 \%$ & $22 \%$ & $12 \%$ & $35 \%$ & $82 \%$ & $46 \%$ & \\
\hline $\mathrm{P}$ & 0.000 & 0.0001 & $3 \mathrm{E}-05$ & 0.1962 & 0.081 & 0.004 & 0.067 & 0.769 & 0.002 & 0.030 & 0.0030 & 0.014 & 40.00 & 0.002 & 70.04 & 0.4113 & 0.0015 & 0.71 & 0.08 & \\
\hline $\mathrm{pE}$ & 0.0525 & 0.0005 & 50.5169 & 0.3637 & 0.275 & 0.021 & 0301 & 0.027 & & 2033 & 0.1268 & 80.331 & 0.395 & 0.212 & 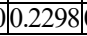 & & 500055 & \begin{tabular}{|l|l|l|}
5 & 0.3662 \\
\end{tabular} & & \\
\hline
\end{tabular}




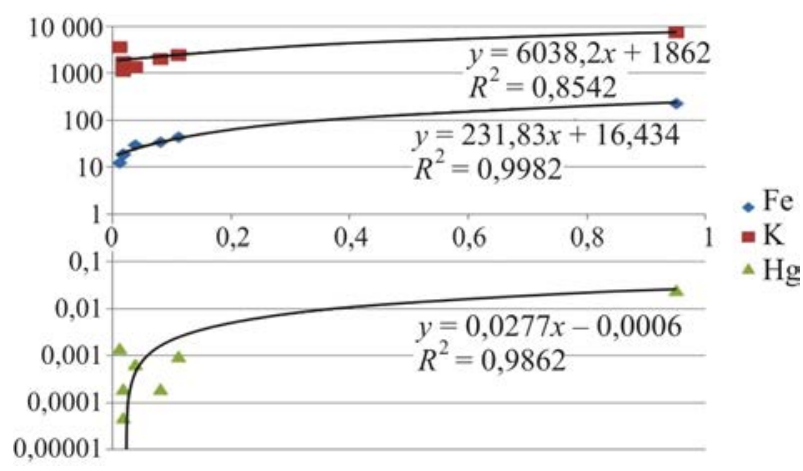

Figure 1. A relationship between arsenic concentrations and contents of various elements in tissue of internal organs taken out of white male Wistar rats from the control group ( $\mathrm{X}$ axis shows arsenic concentration, $\mu \mathrm{g} / \mathrm{g}$; Y axis shows concentrations of elements, $\mu \mathrm{g} / \mathrm{g}$ )

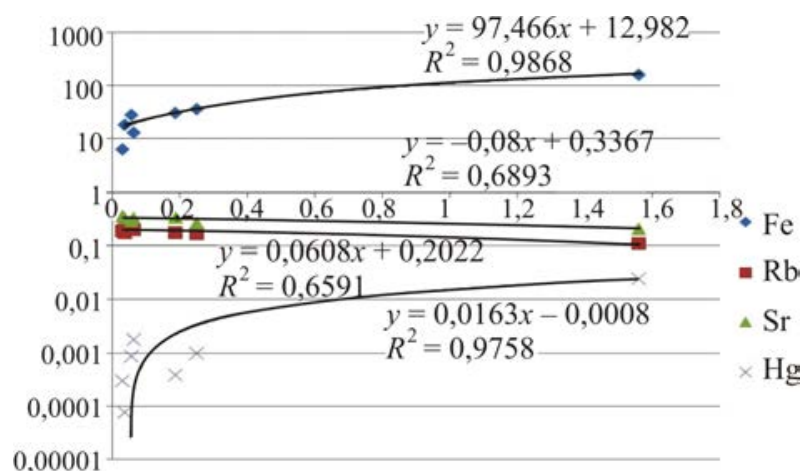

Figure 2. A relationship between arsenic concentrations and contents of various elements in tissue of internal organs taken out of white male Wistar rats from the test group ( $\mathrm{X}$ axis shows arsenic concentration, $\mu \mathrm{g} / \mathrm{g}$; $\mathrm{Y}$ axis shows concentrations of elements, $\mu \mathrm{g} / \mathrm{g}$ )

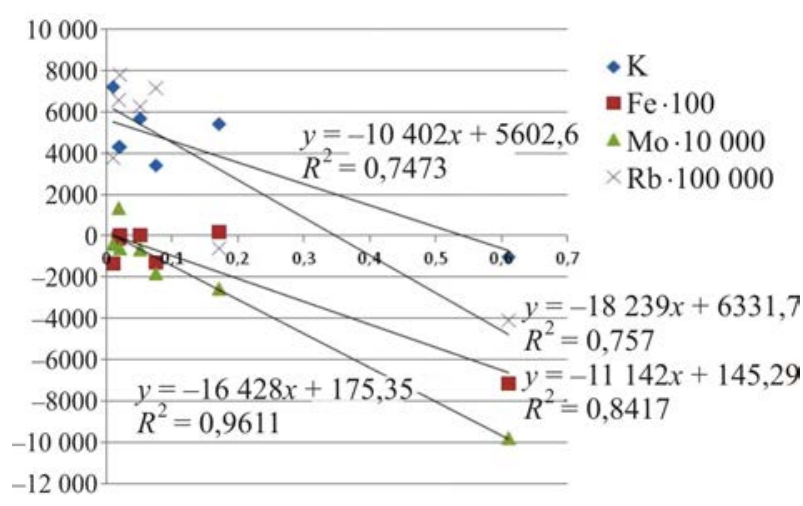

Figure 3. A correlation between changes in arsenic concentration and concentrations of other elements in tissues of organs taken out of white male Wistar rats under sub-acute oral combined exposure to arsenic and antimony in doses equal to $0.015 \mathrm{mg} / \mathrm{kg} /$ day and $0.061 \mathrm{mg} / \mathrm{kg} /$ day respectively ( $\mathrm{X}$ axis shows a difference between arsenic concentration in the test and control groups, $\mu \mathrm{g} / \mathrm{g}$; $\mathrm{Y}$ axis shows a difference between concentrations of elements in the test and control groups, $\mu \mathrm{g} / \mathrm{g}$; to bring all concentrations to the same dimension, we multiplied iron concentration

by 100 ; molybdenum, by 10,000 ; lead, by 100,000 )
We detected lower contents of chromium (by $72 \%, p<0.05$ ), manganese (by $83 \%, p<0.05$ ), iron (by $68 \%, \mathrm{p}<0.05$ ), and nickel (by $53 \%$, $\mathrm{p}<0.05)$.

We examined tissues of thyroid gland taken out of animals from the test group and detected an apparent trend for increased average arsenic contents and an increase in dispersion of the parameter (by $500 \%, \mathrm{pF}<0.05$ ); there were also higher concentrations of potassium (by $153 \%$, $\mathrm{p}<0.05$ ), zinc (by $34 \%, \mathrm{p}<0.05$ ), selenium (by $37 \%, \mathrm{p}<0.05$ ), and bromine (by $91 \%, \mathrm{p}<0.05$ ). We also detected a trend for higher chlorides concentrations together with an increase in dispersion of the parameter (by $498 \%, \mathrm{pF}<0.05$ ). A trend for lower concentrations was detected for chromium (by $50 \%, \mathrm{pF}<0.05$ ), copper (by $31 \%, \mathrm{pF}<0.05$ ); there were statistically authentically lower concentrations of nickel (by $58 \%$, $\mathrm{p}<0.05$ ) and strontium (by $21 \%, \mathrm{p}<0.05$ ).

We detected a direct relationship between arsenic concentration and contents of potassium, iron, and mercury in the control group (Figure 1); arsenic concentration and contents of iron and mercury in the test group (Figure 2).

There was an inverse relationship between arsenic concentration and contents of strontium and rubidium in organs of animals from the test group (Figure 2).

We analyzed a correlation between higher arsenic concentrations in tissues of organs taken out of animals from the test group against the control and changes in contents of other elements; our analysis revealed a statistically authentic inverse correlation between arsenic concentration and an increase in concentrations of potassium, molybdenum, iron, and lead (Figure 3).

Results and discussion. Our experiment allowed us to obtain data on changes in elemental structure of internal organs taken from white male Wistar rats under combined sub-acute oral exposure to arsenic and antimony in doses equal to $0.015 \mathrm{mg} / \mathrm{kg} / \mathrm{day}$ and $0.061 \mathrm{mg} / \mathrm{kg} / \mathrm{day}$. In general, all the data are well in line with common toxic effects produced by these semimetals known as "endocrine destroyers" and "thiol poisons". It becomes apparent via prevailing arsenic accumulation $(1.56 \mu \mathrm{g} / \mathrm{g})$ and antimony accumulation 
$(0.021 \mu \mathrm{g} / \mathrm{g})$ in blood; arsenic was also accumulated in the heart $(0.249 \mu \mathrm{g} / \mathrm{g})$, lung tissues $(0.183 \mu \mathrm{g} / \mathrm{g})$, and thyroid gland $(0.060 \mu \mathrm{g} / \mathrm{g})$. Antimony concentration was lower than detection limit in other internal organs and it is coherent with data on antimony compounds being scarcely capable to be absorbed into a body out of the digestive tracts [7, 24].

Although antimony and arsenic were the only elements consumed by animals from the test group in substantially higher quantities, tissues of all the examined organs contained other elements in quantities that differed from those detected in tissues of animals from the control group, some being higher and some lower. Thus, the following elements were detected in higher concentrations in tissues of animals from the test group as compared with animals from the control group:

- chlorides (blood, liver, kidneys, heart, and thyroid gland);

- potassium (liver, kidneys, heart, lungs, thigh muscle, and thyroid gland);

- calcium (blood, liver, kidneys, and thigh muscle);

- selenium (heart and thyroid gland);

- bromine (liver, kidneys, lungs, and thyroid gland);

- rubidium (liver).

The following elements were detected only in lower concentrations in tissues of animals from the test group as compared with animals from the control group:

- iron (blood, lungs, and thigh muscle);

- nickel (heart, thigh muscle, and thyroid gland);

- copper (blood, liver, heart, and thyroid gland);

- molybdenum (blood, heart, and lungs).

The following elements were contained in certain internal organs in higher concentrations, and in other ones, in lower concentrations in animals from the test group against the control:

- sulfur (increased concentrations in kidneys and thigh muscle, but lower one in the thyroid gland);

- chromium (lower concentrations in blood, thigh muscle, and thyroid gland, and higher concentrations in the liver);
- manganese (lower concentrations in blood and thigh muscle, and higher concentrations in the kidneys);

- zinc (lower concentrations in the lungs, and higher concentrations in the kidneys and the thyroid gland);

- strontium (higher concentrations in thigh muscle, and lower ones in the thyroid gland);

- lead (higher concentrations in the lungs and lower ones in blood).

Obviously concentrations of the abovementioned elements (except form antimony and arsenic) grow due to redistribution of elements that are contained in a body to organs that are "in need" after intoxication with antimony and arsenic. Therefore we can state that all the examined organs with increased concentrations of elements are susceptible to intoxication with arsenic and antimony; here we can mention blood (increased concentrations of chlorides and calcium), liver (increased concentrations of chlorides, potassium, calcium, chromium, zinc, bromine, and rubidium), heart (increased concentrations of chlorides and potassium), lungs (increased concentrations of sulfur, calcium, bromine, and lead), thigh muscle (increased concentrations of potassium, calcium, and strontium), thyroid gland (increased concentrations of chlorides, potassium, zinc, and bromine).

At the same time there is a well-known toxic effect produced by metals when they replace other metals and co-enzymes and displace them out of molecules. Hence the detected decreases in concentrations of chromium, manganese, iron, copper, molybdenum, selenium, zinc, nickel, and strontium in tissues are naturally caused by toxic damage done to the heart, liver, blood system, lungs, muscles, and thyroid gland. It is interesting to note that tissues of kidneys taken out of experimental animals didn't contain any of the abovementioned elements in concentrations lower than standard ones. On the contrary, there were increased manganese concentrations in the kidneys and it was obviously due to their increased functional activity caused by occurring toxic effects produced by antimony and arsenic. Table 4 contains lists of elements that 
were contained in organs of the experimental animals in concentrations being either higher or lower than standard ones.

Table 4

Distribution of elements in tissues of internal organs taken out of white mal Wistar rats from the test group against the control group in a sub-acute (21 day) experiment involving oral introduction of antimony and arsenic in doses equal to $0.061 \mathrm{mg} / \mathrm{kg} /$ day and $0.015 \mathrm{mg} / \mathrm{kg} /$ day

\begin{tabular}{|l|c|c|}
\hline \multicolumn{1}{|c|}{ Organs } & $\begin{array}{c}\text { Decreased } \\
\text { concentrations }\end{array}$ & $\begin{array}{c}\text { Increased } \\
\text { concentrations }\end{array}$ \\
\hline Blood & $\begin{array}{c}\mathrm{Cr}, \mathrm{Mn}, \mathrm{Fe}, \\
\mathrm{Cu}, \mathrm{Mo}, \mathrm{Pb}\end{array}$ & $\mathrm{Cl}, \mathrm{Ca}$ \\
\hline Liver & $\mathrm{Cu}$ & $\begin{array}{c}\mathrm{Cl}, \mathrm{K}, \mathrm{Ca}, \mathrm{Cr}, \\
\mathrm{Zn}, \mathrm{Br}, \mathrm{Rb}\end{array}$ \\
\hline Kidneys & & $\begin{array}{c}\mathrm{S}, \mathrm{Cl}, \mathrm{K}, \mathrm{Ca}, \\
\mathrm{Mn}, \mathrm{Br}\end{array}$ \\
\hline Heart & $\mathrm{Ni}, \mathrm{Cu}, \mathrm{Se}, \mathrm{Mo}$ & $\mathrm{Cl}, \mathrm{K}$ \\
\hline Lungs & $\mathrm{Fe}, \mathrm{Zn}, \mathrm{Mo}$ & $\mathrm{K}, \mathrm{Br}, \mathrm{Pb}$ \\
\hline Thigh muscle & $\mathrm{Cr}, \mathrm{Mn}, \mathrm{Fe}, \mathrm{Ni}$ & $\mathrm{S}, \mathrm{K}, \mathrm{Ca}, \mathrm{Sr}$ \\
\hline Thyroid gland & $\mathrm{Cr}, \mathrm{S}, \mathrm{Ni}, \mathrm{Cu}, \mathrm{Se}, \mathrm{Sr}$ & $\mathrm{Cl}, \mathrm{K}, \mathrm{Zn}, \mathrm{Br}$ \\
\hline
\end{tabular}

We should note that increased concentrations of elements indicate that metabolic processes related to those elements are active; obviously, when concentrations go down, it means these processes are inactive. Consequently, elemental deficiency in most organs, except from the kidneys, means they are sus- ceptible to intoxication and toxic effects influence biochemical processes that involve participation of chromium, manganese, iron, copper, molybdenum, nickel, selenium, and strontium.

Therefore, the results we obtained in our experiment allow us to conclude that:

1. Arsenic in tissues of the liver, kidneys, muscles, thyroid gland and whole blood of white rats and antimony in whole blood of white rats are markers of oral exposure to antimony and arsenic contained in a complex mixture.

2. Sub-acute combined oral exposure of white male Wistar rats to arsenic in a dose equal to $15 \mu \mathrm{g} / \mathrm{kg}$ and antimony in a dose equal to $61 \mu \mathrm{g} / \mathrm{kg}$ introduced into a body as components in a complex mixture results in increased concentrations of chlorine, potassium, sulfur, calcium, rubidium, zinc, manganese, and chromium in the liver and kidneys, and decreased concentrations of chromium, manganese, iron, copper, molybdenum, nickel, selenium, and strontium in blood, heart, thyroid gland, thigh muscle, and lungs; all these metals are elemental markers of exposure.

Funding. The research was granted financial support by the Russian Foundation for Basic Research (grant No. 17-05-00056).

Conflict of interests. The authors declare there is no any conflict of interests.

\section{References}

1. Koval'skii V.V. Biogeokhimicheskie provintsii SSSR i metody ikh izucheniya [Biogeochemical provinces in the USSR and techniques applied to study them]. Trudy Biogeokhimicheskoi laboratorii ANSSSR, Moscow, 1960, 11 p. (in Russian).

2. Koval'skii V.V. Problemy biogeokhimiimi kroelementov i geokhimicheskoi ekologii [Issues related to biogeochemistry of microelements and geochemical ecology]. In: Yu.V. Koval'skii ed. Moscow, Rossel'khozakademiya Publ., 2009, 357 p. (in Russian).

3. Ermakov V.V. Geochemical ecology and biogeochemical criteria for estimating the ecologic state of biospherictaxons. Geokhimiya, 2015, no. 3, pp. 203-221 (in Russian).

4. D'yakovich M.P., Rukavishnikov V.S., Kazakova P.V., Finogenko I.A., Bokmel'der E.P., Solov'eva I.Yu. Kachestvo zhizni, svyazannoe so zdorov'em: otsenka i upravlenie: monografiya [Health-related life quality: assessment and management: a monograph]. In: V.S. Rukavishnikov ed. Irkutsk, Nauchnyi tsentr rekonstruktivnoi i vosstanovitel'noi khirurgii Sibirskogo otdeleniya RAMN Publ., 2012, 168 p. (in Russian).

5. Zaitseva N.V., Ustinova O.Yu., Zemlyanova M.A. Medical and preventive technologies of the management of the risk of health disorders associated with exposure to adverse environmental factors. Fundamental'nye issledovaniya, 2014, no. 10-4, pp. 665-670 (in Russian).

6. Gurvich V.B., Plotko E.G., Kuzmin S.V., Selyankina K.P., Ryzhov V.V., Makarenko N.P., Nadeenko V.G. Aktual'nye problemprofilakticheskoi meditsiny v Ural'skom regione [Vital issues of preventive medicine in the Urals]. Sbornik nauchnykh trudov i nauchno-prakticheskikh rabot, posvyashchennyi 80-letiyu gossanepidsluzhby Rossii, Ekaterinburg, 2002, pp. 76-81 (in Russian). 
7. Avtsyn A.P., Zhavoronkov A.A., Rish M.A., Strochkova L.S. Mikroelementozy cheloveka: etiologiya, klassifikatsiya, organopatologiya: monografiya [Microelemental disorders in a human body: etiology, classification, and organopathology: a monograph]. Moscow, Meditsina Publ., 1991, 496 p. (in Russian).

8. Bulatova E.M., Gabrusskaya T.V., Bogdanova N.M., Yalfimova E.A. Current view on physiologic role of calcium in human organism. Pediatriya, 2007, vol. 86, no. 5, pp. 117-124 (in Russian).

9. Beggs M.R., Alexander R.T. Intestinal absorption and renal reabsorption of calcium throughout postnatal development. Exp. Biol. Med., 2017, vol. 242, no. 8, pp. 840-849. DOI: 10.1177/1535370217699536

10. Titan v organizme cheloveka: rol', istochniki, nekhvatka i izbytok. [Titanium in a human body: role, sources, deficiency and excess]. Zdorov'eipsikhologiya: vse o fizicheskom i dushevnomzdorov'e. Blog Alekseya Rybaka. Available at: http://zdips.ru/zdorovoe-pitanie/mineraly/1635-titan-v-organizmecheloveka.html (15.12.2018) (in Russian).

11. Biologicheskaya rol' titana. Dioksid titana $\mathrm{TiO}_{2}$ (dvuokis' titana, titanium dioxide) [Biological role of titanium. Titanium dioxide $\mathrm{TiO}_{2}$ ]. Available at: http://www.titandioxide.ru/articles/art_21.php (15.12.2018) (in Russian).

12. Oganyan A.A., Neelova O.V. Biologicheskaya rol' khroma, primenenie dikhromata kaliya v farmatsevticheskom analize [Biological role of chromium and application of potassium dichromate in pharmaceutical analysis]. Uspekhi sovremennogo estestvoznaniya, 2011, no. 8, pp. 227-227 (in Russian).

13. Mamyrbaev A.A. Toksikologiya khroma i ego soedinenii: monografiya [Toxicology of chromium and its compounds: a monograph]. Aktobe, 2012, 284 p. (in Russian).

14. Dobson A., Erikson K.M., Aschner M. Manganese Neurotoxicity. Annals of the New York Academy of Science, 2004, vol. 1012, pp. 115-128. DOI: 10.1196/annals.1306.009

15. Zhelezo v organizme, regulyatsiya [Iron in a body and its regulation]. Availableat: http://biohimik.net/prichiny-anemii/zhelezo-v-organizme/zhelezo-v-organizme-regulyatsiya (15.12.2018) (in Russian).

16. Obmen medi $\mathrm{v}$ organizme $\mathrm{i}$ egonarushenie [Metabolism of copper in a body and its disorders]. Available at: http://sunmuseum.ru/patofiziologiya/1527-obmen-medi-v-organizme-i-ego-narushenie.html (15.12.2018) (in Russian).

17. Rish M.A. Geneticheskii kontrol' mikroelementozov u cheloveka i zhivotnykh. Geokhimicheskaya ekologiya i biogeokhimicheskoe raionirovanie biosfery: materialy vtoroi Rossiiskoi shkoly [Genetic control over microelemental disorders in human and animals. Geochemical ecology and biogeochemical zoning in the biosphere: the materials collected by the second all-Russian school]. Moscow, 1999, pp. 205-207 (in Russian).

18. Goncharova E.I., Rossman T.G. A role for metalothionein and zinc in spontaneous mutagenesis. Cancer Res., 1994, vol. 54, no. 20, pp. 5318-5323.

19. Stefanidou M., Maravelias C., Dona A., Spiliopoulou C. Zinc: a multipurpose trace element. Arch. Toxicol., 2006, vol. 80, no. 1, pp. 1-9.

20. Selenvorganizme [Selenium in a body]. Biologiya i meditsina. Available at: http://medbiol.ru/medbiol/har/0055c9fd.htm (15.12.2018) (in Russian).

21. Gosse J.A., Taylor V.F., Jackson B.P., Hamilton J.W., Bodwell J.E. Monomethylated trivalent arsenic species disrupt steroid receptor interactions with their DNA response elements at non-cytotoxic cellular concentrations. J. Appl. Toxicol., 2014, vol. 34, no. 5, pp. 498-505. DOI: 10.1002/jat.2898

22. Mak Dermott M. Sekrety endokrinologii [Secrets of endocrinology]. 2-nd edition. Sankt-Peterburg: Binom - Nevskii Dialekt Publ., 2001, 464 p.

23. Sur'ma «Rvotnyi kamen'» [Antimony or "vomitive emetic stone"]. Farmakognoziya. Available at: http://pharmacognosy.com.ua/index.php/makro-i-mikro-chudesa/surma-rvotniykamen (12.11.2018) (in Russian).

24. Klinicheskaya mikroelementologiya. Sur'ma [Clinical microelementology. Antimony]. Mikroelement. Nauchno-meditsinskii tsentr. Available at: www.microelement.ru/uslovno-toksichnye/99-surma.html (15.12.2018) (in Russian).

Franovskii S.Yu., Turbinskii V.V., Oks E.I., Bortnikova S.B. Elemental markers of exposure under combined oral introduction of chemical mixtures with prevalent antimony and arsenic into white wistar rats. Health Risk Analysis, 2019, no. 3, pp. 94-103. DOI: 10.21668/health.risk/2019.3.11.eng

Received: 05.02.2019

Accepted: 25.05.2019

Published: 30.09.2019 
UDC 613.6.027: 613.63: 613.65: 616-084

DOI: $10.21668 /$ health.risk/2019.3.12.eng

\title{
OXIDATIVE STRESS AND ANTIOXIDANT PROTECTION IN PEOPLE OF VARIOUS AGE UNDER CONTACT WITH ADVERSE OCCUPATIONAL FACTORS
}

\author{
I.A. Umnyagina, T.V. Blinova, L.A. Strakhova, V.V. Troshin, S.A. Kolesov, O.V. Sherstobitova \\ Nizhegorodskiy Scientific Research Institute for Hygiene and Occupational Pathology, 20 Semashko Str., \\ Nizhniy Novgorod, 603950, Russian Federation
}

Free radical oxidation and antioxidant protection system has been examined for decades. However, experts still haven't been able to determine cause-and-effect relations between oxidative stress, age, working conditions, and a risk of functional and organic disorders that can develop in a human body.

Our research goal was to detect peculiarities related to age dynamics of integral parameters that describe oxidative stress and total antioxidant capacity of blood serum; to assess their changes depending on impacts exerted by adverse occupational factors on a worker's body.

244 people aged from 18 to 65 were under observation; they all had physical loads at their workplaces and contacted adverse chemicals. These people underwent regular medical check-ups at a consultancy polyclinic of the Rospotrebnadzor's Nizhniy Novgorod Scientific Research Institute for Hygiene and Occupational Pathology.

The first stage in the research involved mass screening aimed at detecting parameters related to oxidative stress and total antioxidant capacity of blood serum in all the examined people. At the second stage in research we analyzed levels of oxidative stress and total antioxidant capacity of blood serum taking into account age of an examined person and impacts exerted by adverse occupational factors $(n=174)$.

Integral parameters of oxidative stress and total antioxidant capacity of blood serum were determined with a calorimetric biochemical microplate procedure.

We detected that oxidative stress grew with age and antioxidant protection dropped. It was shown that adverse chemical factors exerted more apparent impacts on oxidative stress and antioxidant capacity of blood serum on people from the same age group than physical loads. We determined integral parameters of oxidative stress and antioxidant capacity of blood serum in people from various age groups and limits of their age-dependent changes. These parameters can serve as informative tests for monitoring over health, assessing gravity of a disease, its forecast, treatment efficiency, and preventive activities.

Key words: oxidative stress, total antioxidant capacity of blood serum, age, physical overloads, chemical factors.

For many years, researchers have been focusing on free radical oxidation processes. Multiple research results prove there is a tight correlation between oxidative stress (OS) and anti-oxidant protection and various diseases, functional disorders, and psycho-emotional state of a body [1-4]. Adverse occupational factors (physical, chemical, and psychophysiological ones) also make for disorders in balanced functioning of oxidant and anti-oxidant systems [5, 6]. Latest research confirms a hypothesis that OS makes a significant contribution into pathogenesis of ageing. Free radical or "oxidation theory of ageing" states that a

(c) Umnyagina I.A., Blinova T.V., Strakhova L.A., Troshin V.V., Kolesov S.A., Sherstobitova O.V., 2019

Irina A. Umnyagina - Candidate of Medical Sciences, Director (e-mail: recept@nniigp.ru; tel.: +7 (831) 419-61-94; ORCID: http://orcid.org/0000-0002-9276-7043).

Tat'yana V. Blinova - Doctor of Medical Sciences, Leading researcher at the Clinical Department (e-mail: btvdn@yandex.ru; tel.: +7 (915) 944-38-75; ORCID: http://orcid.org/0000-0001-5254-9378).

Larisa A. Strakhova - Researcher at the Clinical Department (e-mail: recept@nniigp.ru; tel.: +7 (831) 419-61-94; ORCID: http://orcid.org/0000-0003-0672-6622).

Vyacheslav V. Troshin - Candidate of Medical Sciences, Head of the Clinical Department (e-mail: recept@nniigp.ru; tel.: +7 (831) 419-61-94; ORCID: http://orcid.org/0000-0002-7077-0014).

Sergei A. Kolesov - Candidate of Biological Sciences, Senior researcher at the Clinical Department (e-mail: recept@nniigp.ru; tel.: +7 (831) 419-61-94; ORCID: http://orcid.org/0000-0003-4379-0228).

Ol'ga V. Sherstobitova - Dermatovenerologist at the Consultancy Polyclinic (e-mail: recept@nniigp.ru; tel.: +7 (831) 419-61-94; ORCID: http://orcid.org/0000-0001-5090-5594). 
body grows old due to products damaged by free radicals. These products accumulate in body cells with time $[7,8]$. As a body grows older, metabolic disorders occur in it, it becomes more susceptible to various diseases, and a person suffers from more and more chronic diseases. It all leads to a decrease in anti-oxidant protection processes and to free radicals growth in a body [9]. Excessive free radicals accumulation in middle-aged and elderly people is unquestionable. But free radicals occurrence in younger people and subsequent age dynamics require explanation as there are certain related issues here: whether excessive free radicals always exert negative impacts on a body; how apparent OS is in practically healthy people; whether OS intensity in a specific individual is constant or it can change depending on a person's age, working conditions, or effects produced by various adverse occupational factors. When experts analyze risks of health disorders for people who have to work in adverse working conditions, they often face a question: can OS parameters serve as biomarkers of an effect produced by adverse occupational factors on a body resulting in functional and organic disorders? Similar issues arise as regards body antioxidant system. Over recent years, some research has been performed proving that free radicals, being signal molecules, perform significant regulatory functions in a body, and excess antioxidants that eliminate them can lead to a so called "antioxidant" stress [10-12].

Our research goal was to reveal peculiarities related to age dynamics of integral oxidative stress parameters and total antioxidant capacity of blood serum, and to assess their changes depending on impacts exerted by adverse occupational factors on a worker's body.

Data and methods. We examined 244 people who underwent a regular medical check-up at the consultancy polyclinic of Rospotrebnadzor's Nizhniy Novgorod Scientific Research Institute for Hygiene and Occupational Pathology. All the participants gave their voluntary informed consent to be examined and the examination results being published. The performed research didn't infringe on the examined people's rights and didn't endanger their well-being in accordance with the biological and medical ethics requirements fixed in the Helsinki Declaration of the World Medical Association (2000) and the Order by RF Public Healthcare Ministry No. 266 (dated June 19, 2003). We excluded people with chronic diseases in their acute state, as well as with inflammatory and oncologic diseases from our research.

The first stage in the research involved mass screening of parameters related to oxidative stress (OS) and total antioxidant capacity (AOC) of blood serum in all the examined people. Occupation and impacts exerted by occupational factors were not taken into account at this stage in the research. Having analyzed all the obtained results, we divided all the examined people into four age groups; the 1st group $(n+78)$ included young people aged 18-20 $(19.1 \pm 1.5)$; the 2 nd group $(n=84)$, young people aged 21-35 (26.5 \pm 7.5$)$; the 3rd group $(n=67)$, middle-aged people aged 36-59 $(46.6 \pm 9.5)$; the 4 th group $(n=15)$, elderly people aged 60 an older $(56.2 \pm 5.1)$.

At the second stage in the research we analyzed OS and AOC taking into account age of an examined person and impacts exerted by adverse occupational factors $(n=174)$. Depending on impacts exerted by an adverse occupational factor, all the examined people were divided into five groups; the 1 st $(n=33$, aged $18-20)$ and the 2 nd $(n=34$, aged 21-35) groups were made up of students attending higher educational establishments and doing cyclic sports; the 3rd group $(n=52$, aged 21-35) were workers employed at a metallurgic plant that manufactured pipes; the 4th group $(n=29$, aged 36-65) included workers employed at a metallurgic plant and by a water supply organization; the 5th group $(n=26$, aged 36-65) were workers employed at chemical and bacteriological laboratories. We considered the 
following adverse factors in our research: physical overloads (the 1st, 2nd, and 4th groups) and chemical factors (exposure to formaldehyde, metals aerosols, acrylic polymers, phenol, acids, metals, chlorine, and disinfectants) (the 3rd and 5th groups). Working places and occupational factors were assessed and working conditions categories were established by in-house laboratories of a metallurgic plant and water supply organization according to the Federal Law FZ-426 issued on December 28, 2013 «On specialized assessment of working conditions». According to the above-mentioned assessment, chemicals factors at working places didn't exceed MPC. We assessed physical overloads for students who did cyclic sports as per their heart rate [13].

We determined integral parameters of OS and total AOC with reagent kits «PerOx (TOS/TOC) Kit» and «ImAnOx (TAS/TAC) Kit» manufactured by «Immundiagnostik» (Germany). OS was estimated as per peroxides occurrence in blood serum and was given in $\mu \mathrm{mol} / 1$ of peroxide that was present in a sample. To assess OS intensity in blood serum, we applied values recommended by reagent kits manufacturers; a value lower than $180 \mu \mathrm{mol} / 1$ meant OS was low; $180-310$ $\mu \mathrm{mol} / 1$, average OS: more than $310 \mu \mathrm{mol} / 1$, high OS. AOC was given in $\mu$ mol of exogenous peroxides decayed by antioxidants per 1 liter of blood serum. To assess AOC, we applied values recommended by reagent kits manufacturers; a value lower than $280 \mu \mathrm{mol} / 1$ meant AOC was low; 280-320 $\mu \mathrm{mol} / \mathrm{l}$, average AOC; more than $320 \mu \mathrm{mol} / \mathrm{l}$, high AOC. Blood was taken from the median cubical vein, and all the samples were treated immediately; blood serum was obtained with conventional techniques and stored at minus $80^{\circ} \mathrm{C}$ until it was analyzed.

We processed the results statistically with «AtteStat» software package. We applied non-parametric statistics methods for parameters with their distribution deviating from the standards one. The data were given as median, 25\%- and 75\%-quartiles (Med \pm IQR (25\%-75\%)). Validity of discrepancies between groups was calculated with MannWhitney test. If parameters distribution was standard, the data were given as simple mean $(\mathrm{M}) \pm$ standard deviation $(\sigma)$, and validity was assessed with Student's test. Critical significance of the results was fixed at $p<0.05$.

Results and discussion. We analyzed results of screening examinations and revealed that $\mathrm{OS}$ and $\mathrm{AOC}$ in the examined people were age-dependent. The data are given in the Table 1 .

Table 1

Os and AOC levels frequency and their quantitative characteristics in people from different age groups

\begin{tabular}{|l|c|c|c|c|}
\hline \multirow{2}{*}{ Parameters } & \multicolumn{4}{|c|}{ Age groups } \\
\cline { 2 - 5 } & 1 & 2 & 3 & 4 \\
\cline { 2 - 5 } & $18-20(n=78)$ & $21-35(n=84)$ & $36-59(n=67)$ & 60 and older $(n=15)$ \\
\hline OS and AOC levels & \multicolumn{4}{|c|}{ OS \% / AOC \% } \\
\hline Low & $60.2 / 10.3$ & $34.5 / 10.7$ & $28.4 / 35.2$ & $20.0 / 40.0$ \\
\hline Average & $24.4 / 41.0$ & $25.0 / 31.1$ & $17.9 / 47.8$ & $26.7 / 46.7$ \\
\hline High & $15.4 / 48.7$ & $40.5 / 58.2$ & $53.7 / 17.0$ & $53.3 / 13.3$ \\
\hline Med \pm IQR (25\%-75\%) & \multicolumn{4}{|c|}{ OS $(\mu \mathrm{mol} / \mathrm{l}) / \mathrm{AOC}(\mu \mathrm{mol} / \mathrm{l})$} \\
\hline Med & $176.2 / 320.2$ & $289.0 / 348.5$ & $355.7 / 290.9$ & $394.1 / 280.0$ \\
\hline $25 \%$ & $114.9 / 298.8$ & $131.5 / 293.8$ & $178.0 / 274.4$ & $225.5 / 260.2$ \\
\hline $75 \%$ & $275.8 / 342.0$ & $403.0 / 368.9$ & $600.0 / 304.8$ & $630.9 / 300.0$ \\
\hline $\mathrm{p}$ & \multicolumn{4}{|c|}{$\mathrm{p}_{1,2}=0.006 ; \mathrm{p}_{2,3}=0.009 ; \mathrm{p}_{1,3}=0.00036 ; \mathrm{p}_{3,4}=0.331}$. \\
& $\mathrm{p}^{*}{ }_{1,2}=0.213 ; \mathrm{p}_{2,3}=0.00015 ; \mathrm{p}_{1,3}^{*}=0.00022 ; \mathrm{p}_{3,4}=0.072 ; \mathrm{p}_{2,4}=0.003 ; \mathrm{p}_{1,4}=0.001$. \\
\hline
\end{tabular}

Note: $\mathrm{p}$ is validity of discrepancies in Med $(\mu \mathrm{mol} / \mathrm{l})$ OS between different age groups; $\mathrm{p}^{*}$ is validity of discrepancies in Med $(\mu \mathrm{mol} / \mathrm{l})$ AOC between different age groups. 
Table 2

OS and AOC levels frequency their quantitative characteristics in people from different age groups who are exposed to adverse occupational factors

\begin{tabular}{|c|c|c|c|c|c|}
\hline \multirow{4}{*}{ Parameters } & \multicolumn{5}{|c|}{ Age / Groups / Occupational factors } \\
\hline & \multicolumn{2}{|c|}{$18-20$} & $21-35$ & \multicolumn{2}{|c|}{$36-65$} \\
\hline & 1 & 2 & 3 & 4 & 5 \\
\hline & $\begin{array}{c}\text { Physical } \\
\text { overloads } \\
n=33\end{array}$ & $\begin{array}{c}\text { Physical } \\
\text { overloads } \\
n=34\end{array}$ & $\begin{array}{c}\text { Chemical } \\
\text { factor } \\
n=52\end{array}$ & $\begin{array}{c}\text { Physical } \\
\text { overloads } \\
n=29\end{array}$ & $\begin{array}{c}\text { Chemical } \\
\text { factor } \\
n=26\end{array}$ \\
\hline OS and AOC levels & \multicolumn{5}{|c|}{ OS \% / AOS \% } \\
\hline Low & $78.8 / 9.1$ & $50.0 / 5.9$ & $28.8 / 5.8$ & $31.0 / 27.5$ & $7.7 / 42.3$ \\
\hline Average & $15.2 / 24.2$ & $11.8 / 20.6$ & $21.2 / 11.5$ & $41.4 / 48.3$ & $15.4 / 42.3$ \\
\hline High & $6.0 / 66.7$ & $38.2 / 73.5$ & $50.0 / 82.7$ & $27.6 / 24.2$ & $76.9 / 15.4$ \\
\hline Med \pm IQR $(25-75 \%)$ & \multicolumn{5}{|c|}{ OS $(\mu \mathrm{mol} / \mathrm{l}) / \mathrm{AOC}(\mu \mathrm{mol} / \mathrm{l})$} \\
\hline Med & $107.8 / 341.0$ & $200.8 / 336.7$ & $360.0 / 360.0$ & $252.0 / 294.3$ & $540.0 / 283.7$ \\
\hline $25 \%$ & $56.4 / 320.0$ & $97.9 / 319.6$ & $192.3 / 327.0$ & $107.2 / 277.9$ & $414.1 / 248.7$ \\
\hline $75 \%$ & $138.0 / 385.0$ & $321.8 / 347.9$ & $412.0 / 360.0$ & $310.0 / 317.1$ & $733.3 / 302.7$ \\
\hline $\mathrm{p}$ & \multicolumn{5}{|c|}{$\begin{aligned} \mathrm{p}_{1,2} & =0.0006 ; \mathrm{p}_{2,3}=0.009 ; \mathrm{p}_{2,4}=0.001 ; \mathrm{p}_{4,5}=0.0009 \\
\mathrm{p}^{*}=0.2 & =0.382 ; \mathrm{p}_{2,3}^{*}=0.351 ; \mathrm{p}^{*}{ }_{2,4}=0.033 ; \mathrm{p}_{4,5}^{*}=0.034\end{aligned}$} \\
\hline
\end{tabular}

Note: $\mathrm{p}$ is validity of discrepancies in Med $(\mu \mathrm{mol} / \mathrm{l})$ OS between different age groups and occupational factors; $\mathrm{p}^{*}$ is validity of discrepancies in Med $(\mu \mathrm{mol} / \mathrm{l})$ AOC between different age groups and occupational factors

The obtained results show that peroxides formation intensified with age and it proved that OS grew. Changes to a greater extent were related to high and low OS. We should note that most younger people tended to have low OS as high OS was met 4 times less frequently among them. But a share of people with high OS started to grow among those aged 21 and older, by $25.1 \%$ in the 2 nd group, and by $13.2 \%$ in the 3 rd group against previous groups. A share of people with low OS in groups $2-4$ decreased by $25.7 \%, 6.1 \%$ and $8.4 \%$ respectively. Peroxides contents in blood serum grew in people who were younger than $59 \quad\left(\mathrm{p}_{1,2}=0.006 ; \mathrm{p}_{2,3}=0.009\right.$; $\left.\mathrm{p}_{1,3}=0.00036\right)$ and didn't change in the following years $\left(\mathrm{p}_{3,4}=0.331\right)$. Average OS frequency didn't depend on age and a share of people with average OS varied from 17.9 to $26.7 \%$.

Changes in AOC were oppositely directed. High and average AOC prevailed among young people and low AOC was detected only in $10 \%$ people from this age group. Decayed peroxides contents in blood serum didn't differ authentically in the $1 \mathrm{st}$ and 2 nd groups $\left(\mathrm{p}^{*}{ }_{1,2}=0.213\right)$. Low and average AOC prevailed among people from the 3rd and 4th groups and high AOC was detected only in $13-17 \%$ of the examined people from these groups. Decayed peroxides contents in blood serum didn't differ authentically in these groups $\left(\mathrm{p}_{3,4}=0.072\right)$. AOC parameters in middle-aged and elderly people were different from those detected in young people $\left(\mathrm{p}_{2,3}=0.00015 ; \mathrm{p}_{1,3}=0.00022\right.$; $\left.\mathrm{p}^{*}{ }_{2,4}=0.003 ; \mathrm{p}^{*}{ }_{1,4}=0.001\right)$. Average AOC frequency didn't depend on age and varied from 31.1 to $47.8 \%$.

Table 2 contain $s$ the results of changes in OS and AOC parameters in people from different age groups who are exposed to adverse occupational factors.

The obtained results show that impacts exerted by both physical overloads and chemical factors became greater with age and led to higher OS and lower AOC. People who were exposed to chemical factors had authentically higher OS than people from the same age group who had to face physical overloads. This discrepancy was the most apparent among people aged 36-65 (the 4th 
and the 5th groups, $\left.\mathrm{p}_{4,5}=0.0009\right)$. Younger people (aged 18-20) who faced physical overloads at their workplaces had 2 times lower peroxides contents in their blood serum than young people aged 21-35 (the 1st and the 2 nd groups, $\left.\mathrm{p}_{1,2}=0.0006\right)$. Changes in AOC were less dependent on physical overloads and chemical factors among people from the 1st, 2nd, and 3rd groups as AOC remained stably high regardless of any occupational factors. Discrepancies were detected among middle-aged and elderly people and chemical factors had greater adverse effects on AOC than physical overloads $\left(\mathrm{p}_{4,5}=0.034\right)$. Physical overloads at older age promoted more apparent decrease in AOC against parameters detected among young people $\left(\mathrm{p}_{2,4}=0.033\right)$.

Our research revealed that peroxides contents in blood serum increased and total AOC went down with age. It indicated that OS grew and antioxidant protection decreased. We detected age-related dynamics of integral OS and AOC parameters and determined their values for each age group. Low OS and high / average AOC prevailed among younger people. Negative changes in OS and AOC grew in people older than 20, the trend continued up to age of 59 and then the parameters remained stable in most of the examined people. The obtained results on increased OS in elderly people are consistent with literature. Thus, Edrey and Salmon think than ageing involves a decrease in adaptive mechanisms, antioxidant and detoxification reserves of a body that are able to resist high OS [14]. Even if an elderly person consumes antioxidant micronutrients, it often doesn't produce any positive effects [15]. Excess peroxides quantities were revealed even in practically healthy people aged 18-20 and 21-35. Peroxides contents in blood serum varied from 436.2 to $733.7 \mu \mathrm{mol} / 1$ and AOC was high, from 350.0 to $386.5 \mu \mathrm{mol} / 1$. In this case an increase in OS can have a positive regulatory effect aimed at activating antioxidant protection processes. Some researchers showed that lipid peroxidation products caused an adaptive response and increased tolerance to future oxidative stress thus enhancing protective capacities of a body $[16,17]$. A share of people with increased OS parameters went up among people from older age groups. Some researchers believe that disorders in the system of free radical oxidation and antioxidant protection are a significant pathogenetic component in development of various pathologies and these parameters can be a risk factor that causes this development. Therefore young people should have regular medical checkups aimed at determining free radicals occurrence and antioxidant protection parameters. Should there be any negative changes, a person has to undergo a more profound medical examination, pay greater attention to his or her work and rest regime and nutrition. Should there be any persistent disorders in antioxidant protection, a physician might prescribe medications or biologically active food additives in order to increase resistance to OS and enhance antioxidant protection of a body.

Our research revealed different changes in OS depending on exposure to an adverse factor in different age groups. Physical overloads tend to have greater adverse effects on free radical oxidation system with age. Young people aged 18-20 and 21-36 are more resistant to oxidative stress under physical overloads. High AOC prevailed among people from these age groups. Our research results indicate that within the same age group OS is more apparent in people who are exposed to chemical factors than in those who have to face physical overloads at their workplace. Obviously it is due to a body getting gradually adapted to physical loads. Similar adaptation to a chemical factor never occurs. Constant exposure to chemicals, even if their concentrations in a working area don't exceed MPC, exerts negative impacts on metabolism, organs, and systems in a body. Workers employed at a metallurgic plant and those who deal with water supply and treatment are exposed to chemical 
factors that can cause OS and damage antioxidant protection of a body. Experimental toxicological research revealed that multiple chemical environmental factors (nitrogen oxide, sulfur dioxide, formaldehyde, cigarette smoke etc.) can cause free radicals formation and it results in OS and damage to DNA, proteins, and lipids, mutagenicity and anti-inflammation factors stimulation [18, 19]. Besides, ecological contaminants in the environment can act at the molecular level and damage any molecules (for example, polyunsaturated fat acids, glutathione, antioxidant enzymes, and some aminoacids) and it can lead to a decrease in antioxidant protection against free radicals [20]. When water is chlorinated, hypochlorous acid occurs in the process; this substance is highly reactive and causes singlet oxygen formation and greater OS. Redox metals (iron, copper, chrome, cobalt, and others) that occur in water can have negative effects on mitochondrial membranes, produce free radicals, cause OS and inhibit antioxidant protection [21].

Conclusions. So, our research allowed to determine age-related dynamics of integral OS and AOC parameters and their val- ues for each age group, to differentiate dependence of changes in them on a type of an adverse occupational factor in different age groups. We can assume that colorimetric techniques for integral $\mathrm{OS}$ and $\mathrm{AOC}$ assessment and gradation of their level that we applied in our work give a relevant picture of OS and AOC intensity depending on age and impacts exerted by adverse occupational factors. These parameters can be applied in practical healthcare as routine biochemical tests aimed at assessing oxidationantioxidation system; we recommend to apply them for analyzing risks related to a worker's body being exposed to adverse occupational factors, both physical and chemical ones. They can also serve as informative tests for monitoring over health, assessing gravity of a disease and forecasting its course, as well as assessing treatment efficiency and preventive activities implementation.

Funding. The research was not granted any sponsor support.

Conflict of interests. The authors state there is no any conflict of interests.

\section{References}

1. Martusevich A.K., Karuzin K.A. Oksidativnyi stress i ego rol' v formirovanii dizadaptatsii i patologii [Oxidative stress and its role in the formation of disadaptation and pathology]. Bioradikaly i antioksidanty, 2015, vol. 2, no. 2, pp. 5-18 (in Russian).

2. Rosales-Corral S., Tan D.-X., Manchester L., Reiter R.J. Diabetes and Alzheimer Diseasetwo overlapping pathologies with the same background: Oxidative Stress. Oxidative Medicine and Cellular Longevity, 2015, 14 p. Available at: https://www.hindawi.com/journals/omcl/2015/985845/ (26.09.2018). DOI: 10.1155/2015/985845.

3. Soazig L.L., Gilles S., Martinez M.C., Ramaroson A. Oxidative Stress and Metabolic Pathologies: From an Adipocentric Point of View. Oxidative Medicine and Cellular Longevity, 2014, no. 2014,18 p. DOI: $10.1155 / 2014 / 908539$

4. Pavlyuchenko I.I., Dydyshko E.I., Okhremenko O.S. Comparative analysis of the dynamics of the immune-antioxidant status of the pro-antioxidant system in patients with thyroid. Kubanskii nauchnyi meditsinskii vestnik, 2017, no. 5, pp. 59-62 (in Russian). DOI: 10.25207/1608-6228-201724-5-59-62

5. Rakhmanov R.S., Blinova T.V., Kolesov S.A., Strakhova L.A., Troshin V.V., Umnyagina I.A., Sapozhnikova M.A. Evaluation of prognostic significance of functional and biochemical indices for health status assessment in young person's working in tube-casting plants. Kubanskii nauchnyi meditsinskii vestnik, 2017, no. 2, pp. 123-128 (in Russian). DOI: 10.25207/1608-62282017-2-123-128 
6. Hawley B., L'Orange C., Olsen D.B., Marchese A.J., Volckens J. Oxidative stress and aromatic hydrocarbon response of human bronchial epithelial cells exposed to petro- or biodiesel exhaust treated with a diesel particulate filter. Toxicological Sciences, 2014, vol. 141, no. 2, pp. 505-514. Available at: https://academic.oup.com/toxsci/article/141/2/505/2511607 (26.09.2018). DOI: $10.1093 /$ toxsci/kfu147

7. Go Y.-M., Jones D.P. Redox theory of aging: implications for health and disease. Clin Sci (London), 2017, vol. 131, no. 14, pp. 1669-1688. Available at: https://www.ncbi.nlm.nih.gov/pmc/articles/PMC5773128/ (24.09.2018). DOI: 10.1042/CS20160897

8. Dues D.J., Andrews E.K., Schaar C.E., Bergsma A.L., Senchuk M.M., Van Raamsdonk J.M. Aging causes decreased resistance to multiple stresses and a failure to activate specific stress response pathways. Aging (Albany N.Y.), 2016, vol. 8, no. 4, pp. 777-795. DOI: 10.18632/aging.100939

9. Kim J.Y., Kim O.Y., Paik J.K., Kwon D.Y., Kim H.-J., Lee J.H. Association of age-related changes in circulating intermediary lipid metabolites, inflammatory and oxidative stress markers, and arterial stiffness in middle-aged men. Age (Dordrecht, Netherlands), 2013, vol. 35, no. 4, pp. 1507-1519. DOI: $10.1007 / \mathrm{s} 11357-012-9454-2$

10. Urbański K., Nowak M., Guzik T.J. Oxidative stress and vascular function. Postepy Biochem, 2013, vol. 59, no. 4, pp. 424-31. DOI: 10.1093/annhyg/mev024

11. Sayin V.I., Ibrahim M.X., Larsson E., Nilsson J.A., Lindahl P., Bergo M.O. Antioxidants accelerate lung cancer progression in mice. Science Translational Medicine, 2014, vol. 6, no. 221, pp. 221-225. DOI: 10.1126/scitranslmed.3007653

12. Van'ek K. Antioksidanty: khoroshie, plokhie, zlye [Antioxidants: good, bad, evil]. Shkola zdorov'ya Titovykh, 2017. Available at: https://articles.shkola-zdorovia.ru/antioksidanty-horoshieplohie-zlye-kristofer-vanek/ (26.09.2018) (in Russian).

13. Valeev G.G. Sposob opredeleniya stepeni peregruzki serdtsa [Method for detecting the degree of cardiac overloading]. FindPatent.RU, 2007. Available at: https://findpatent.ru/patent/230/2306846.html (25.08.2018) (in Russian).

14. Edrey Y.H., Salmon A.B. Revisiting an age-old question regarding oxidative stress. Free Radic Biol. Med., 2014, vol. 71, pp. 368-378.

15. Phillips C. Lifestyle modulators of neuroplasticity: how physical activity, mental engagement, and diet promote cognitive health during aging. Neural Plast, 2017, pp. 3589271. Available at: https://www.ncbi.nlm.nih.gov/pmc/articles/PMC5485368/ (13.08.2018). DOI: 10.1155/2017/3589271

16. European contribution to the study of ROS: A summary of the findings and prospects for the future from the COST action BM1203 (EU-ROS). Redox Biology, 2017, no. 13, pp. 94-162. Available at: https://www.ncbi.nlm.nih.gov/pmc/articles/PMC5975209/ (28.09.2018). DOI: 10.1016/ j.redox.2017.05.007

17. De Gonzalo-Calvo D., De Luxán-Delgado B., Rodríguez-González S., García-Macia M., Suárez F.M., Solano J.J., Rodríguez-Colunga M.J., Coto-Montes A. Oxidative protein damage is associated with severe functional dependence among the elderly population: a principal component analysis approach. Journals of Gerontology-Series a Biological Sciences and Medical Sciences, 2012, vol. 67, no. 6, pp. 663-670. DOI: 10.1093/gerona/glr215

18. Spagnolo A.M., Ottria G., Perdelli F., Cristina M.L. Chemical characterisation of the coarse and fine particulate matter in the environment of an underground railway system: cytotoxic effects and oxidative stress - a preliminary study. Int J. Environ. Res. Public. Health, 2015, vol. 12, no. 4, pp. 4031-4046. Available at: https://www.ncbi.nlm.nih.gov/pmc/articles/PMC4410231/ (24.09.2018). DOI: 10.3390/ijerph120404031

19. Pomierny B., Krzyżanowska W., Smaga I., Pomierny-Chamioło L., Stankowicz P., Budziszewska B. Ethylene Glycol Ethers Induce Oxidative Stress in the Rat Brain. Neurotox Res, 2014, vol. 26, no. 4, pp. 422-429. DOI: 10.1007/s12640-014-9486-8

20. Poljšakand B., Fink R. The Protective Role of Antioxidants in the Defence against ROS/RNS-Mediated Environmental Pollution. Oxid Med Cell Longev, 2014, pp. 671539. DOI: 10.1155/2014/671539 
21. Pizzino G., Irrera N., Cucinotta M., Pallio G., Mannino F., Arcoraci V., Squadrito F., Altavilla D., Bitto A. Oxidative Stress: Harms and Benefits for Human Health. Oxid Med Cell Longev, 2017, pp. 8416763. Available at: https://www.ncbi.nlm.nih.gov/pmc/articles/PMC5551541/ (01.06.2018). DOI: $10.1155 / 2017 / 8416763$

Umnyagina I.A., Blinova T.V., Strakhova L.A., Troshin V.V., Kolesov S.A., Sherstobitova O.V. Oxidative stress and antioxidant protection in people of various age under contact with adverse occupational factors. Health Risk Analysis, 2019, no. 3, pp. 104-111. DOI: 10.21668/health.risk/2019.3.12.eng

Received: 02.10 .2019

Accepted: 26.07.2019

Published: 30.09.2019 
UDC 612.135

DOI: $10.21668 /$ health.risk/2019.3.13.eng

\title{
ASSESSING MORPHOFUNCTIONAL STATE OF MICROCIRCULATION CHANNEL IN SMOKING YOUNG MALES
}

\author{
A.V. Kharin, I.V. Aver yanova, S.I. Vdovenko \\ «Arctica» Scientific and Research Center, the Far Eastern Branch of the Russian Academy of Sciences, 24 Karla \\ Marksa Ave., Magadan, 685000, Russian Federation
}

According to statistical data provided by the World Health Organization, death causes related to smoking annually account for approximately six million deaths all over the world, and here more than five million deaths are directly caused by smoking and more than 600 hundred thousand deaths occur due to passive smoking.

In order to study effects produced by smoking on human microcirculation, we examined capillary blood flow and morphofunctional state of capillaries in smoking and non-smoking people.

195 practically healthy young males aged 17-21 took part in our research; at that moment they were studying at the North-East State University. Microcirculation parameters were examined with non-invasive techniques, namely via computer capillaroscopy performed in a zone of skin swelling near the nail-bed.

We obtained 12 quantitative parameters to characterize the microcirculation channel. Having analyzed the data, we revealed a shift in artery-venous ratio of a capillary dimensions towards a greater diameter of an artery section and smaller diameter of a venous section in a capillary among smoking young males; there was also a decrease in capillary length. Research results allowed revealing a significant correlation between smoking and capillary deformation. Blood capillaries were more twisted and erythrocytic sludges were more apparent among smoking people.

The results we obtained can be added to a database that is applied to create recommendations on healthy lifestyle among young people in order to prevent risks of smoking-related diseases.

Key words: microcirculation, microcirculation channel, capillary blood flow, capillaroscopy, nail-bed, young males, smoking.

Studies on morphofunctional and functional state of blood capillaries are interesting both in terms of their fundamental and applied significance as the microcirculation channel is a reactive area where biochemical and immunologic processes occur. As is well known, blood and tissues in a body are connected via capillaries $[2,3]$. Capillaries are the most sensitive component in the vascular system and the most susceptible to impacts exerted by exo- and endogenous factors [4-6].

At present the microcirculation channel is usually examined with computer capillaro- scopy; the procedure is conventionally performed on capillaries in the skin swelling near the nail-bed as it allows intravital studying of capillaries and estimating their functional state objectively. Such results can't be obtained via any other non-invasive procedure $[7,8]$.

Scientific literature that focuses on issues related to effects produced on a body by smoking has very few works that dwell on examining blood capillaries. However, these works usually describe clinical cases when damage is already done to organs and systems in a body or concentrate on thermal

(C) Kharin A.V., Aver`yanova I.V., Vdovenko S.I., 2019

Anton V. Kharin - Junior researcher at the Laboratory for Physiology of Extremal States (e-mail: anton-harin@yandex.ru; tel.: +7 (964) 455-27-40; ORCID: https://orcid.org/0000-0002-8983-2553).

Inessa V. Aver yanova - Candidate of Biological Sciences, leading research associate of the research Laboratory for Physiology of Extremal States (e-mail: Inessa1382@mail.ru; tel.: +7 (924) 691-11-46; ORCID: http://orcid.org/00000002-4511-6782).

Sergey I. Vdovenko - Candidate of Biological Sciences research associate of the research Laboratory for Physiology of Extremal States (e-mail: Vdovenko.sergei@yandex.ru; tel.: +7 (924) 856-55-50; ORCID: http://orcid.org/00000003-4761-5144). 
and toxic impacts exerted by smoking directly on the vessels in contact zones of the oral cavity. They also contain data obtained via procedures aimed at examining blood flow; such procedures don't allow visualizing any morphological changes in the circulatory channel.

Therefore, visualization of blood flow and capillaries stricture is the most significant issue in assessing influence exerted by tobacco smoking on blood microcirculation.

Given all the above-mentioned, we chose the following research goal: to examine impacts exerted by tobacco smoking on morphofucntional state of capillaries in smoking young males.

Research object and methods. Our participants were practically healthy young males aged 17-21 $(n=195)$; they were students at the North-East State University (Magadan).

To perform comparative analysis and reveal any changes in the system of blood microcirculation caused by long-term addiction to smoking, we divided out examined young males into two groups. The first group was a control one and included non-smoking young males $(n=155)$; the second one was a test group and included young males with their smoking experience ranging from 1 to 10 years $(n=40)$.

Capillaries structure and microcirculation were examined in the skin swelling near the nail-bed with "Capillaroscan-1" computer capillaroscope (Moscow, "New Energy Technologies, Skolkovo" LLC). All the examined young males didn't have frostbites or any other injuries that could produce effects on microcirculation in capillaries located in the nail-bed. The research was accomplished according to ethic principles stated in Helsinki Declaration (2008). Prior to the research, all the participants gave their informed written consent to it.

Morphometric parameters were calculated with a software package provided for the capillaroscope. Microcirculation was registered with uninterrupted videorecording and the software package allowed assessing all the visually observed processes and anatomic structures together with obtaining averaged values for the velocity at which erythrocytes moved in the examined capillaries.

We analyzed the following parameters: blood flow velocity in the arterial, venous, and transitional sections, length and diameter of various sections in capillaries, size of the perivascular zone, capillary network density, an extent to which capillaries were twisted, frequency of erythrocytic sludges, and temperature of an examined skin section.

All the examined parameters were statistically processed with MS Excel; we determined whether distribution was normal or not, mean value and its error $(\mathrm{M} \pm \mathrm{m})$, and significance of discrepancy with Student's t-test. Critical significance was fixed at $p \leq 0.05$. We also performed correlation analysis as per Pearson's test to assess a correlation between morphological structures of capillaries and dynamic properties of microcirculation [9].

Results and discussion. Table 1 contains the results of our comparative analysis performed on blood microcirculation parameters in smoking and non-smoking young males.

We revealed statistically significant differences between smoking and non-smoking young males as per morphofucntional parameters of microcirculation. Thus, the groups had different diameters of the arterial and venous sections in a capillary, different number of erythrocytic sludges, different capillary lengths and coefficients of capillary deformation.

Capillary lumen is known to determine flow capacity for blood corpuscles [4]. Registered values of capillary diameters and blood flow velocity in both examined groups were within physiological standards, had weak correlations with blood flow velocity and an extent to which capillaries were twisted, and 
Compared parameters of blood flow and capillary structure in smoking and non-smoking young males

\begin{tabular}{|l|c|c|c|}
\hline \multicolumn{1}{|c|}{ Parameters } & Non-smoking, $n=155$ & Smoking, $n=40$ & Significance \\
\hline Arterial section diameter, $\mu \mathrm{m}$ & $8.4 \pm 0.1$ & $8.8 \pm 0.1$ & $\mathrm{p}<0.01$ \\
\hline Venous section diameter, $\mu \mathrm{m}$ & $12.2 \pm 0.2$ & $11.6 \pm 0.1$ & $\mathrm{p}<0.002$ \\
\hline Transitional section diameter, $\mu \mathrm{m}$ & $16.9 \pm 0.2$ & $16.6 \pm 0.2$ & $\mathrm{p}=0.20$ \\
\hline Capillary length, $\mu \mathrm{m}$ & $323.0 \pm 5.9$ & $302.0 \pm 6.9$ & $\mathrm{p}<0.03$ \\
\hline Capillary network density, rel. units & $0.041 \pm 0.001$ & $0.039 \pm 0.001$ & $\mathrm{p}=0.09$ \\
\hline Perivascular zone, $\mu \mathrm{m}$ & $91.9 \pm 1.5$ & $89.0 \pm 1.7$ & $\mathrm{p}=0.22$ \\
\hline Velocity in the arterial section, $\mu \mathrm{m} \backslash \mathrm{sec}$ & $231.5 \pm 8.3$ & $204.2 \pm 8.8$ & $\mathrm{p}=0.44$ \\
\hline Velocity in the venous section, $\mu \mathrm{m} \backslash \mathrm{sec}$ & $154.3 \pm 6.2$ & $148.1 \pm 6.9$ & $\mathrm{p}=0.51$ \\
\hline Velocity in the transitional section, $\mu \mathrm{m} \backslash \mathrm{sec}$ & $181.8 \pm 7.0$ & $193.5 \pm 9.8$ & $\mathrm{p}=0.34$ \\
\hline Sludges, units $\backslash$ sec & $3.1 \pm 0.1$ & $3.9 \pm 0.3$ & $\mathrm{p}<0.01$ \\
\hline Coefficient of deformation, rel. units & $0.3 \pm 0.01$ & $0.4 \pm 0.01$ & $\mathrm{p}<0.05$ \\
\hline Skin temperature, $\mathrm{t}^{\circ}$ & $30.6 \pm 0.4$ & $29.9 \pm 0.2$ & $\mathrm{p}=0.08$ \\
\hline
\end{tabular}

didn't depend on how long a young male had been smoking. However, we detected certain deviations among smoking young males as diameters in the arterial section of capillaries tended to be bigger among them, and those in the venous one tended to be smaller. We should note that those capillary diameters were diameters of the visible erythrocytic flow due to capillary walls not being visible in an optical capillaroscope. Therefore, we can assume that more apparent erythrocytes aggregation in smoking young males makes the arterial capillary section widen.

The perivascular zone is a significant parameter that characterizes intensity of the transcapillary exchange [8]. Size of the perivascular zone depends on an overall exchange surface of a capillary that is determined by its length and diameter. Although we detected significant discrepancies between groups as regards capillary length and diameters, there were no significant differences in sizes of perivascular zones.

Obviously, capillaries in smoking young males are shorter due to a higher coefficient of deformation determined for the vessels. It was confirmed by data obtained via correlation analysis as the coefficient of deformation tended to have an inverse correlation with a capillary length and amounted to $r=-0,6$ $(p<0.05)$. An extent to which capillaries were twisted had not only quantitative but also qualitative properties as smoking young males tended to have more apparently deformed capillaries (Figure 1).

At the same time we detected a correlation between the coefficient of deformation and capillary network density. The greatest number of capillaries per one unit of area was detected in young males with the most twisted capillaries. Probably, a greater number of capillaries is a compensatory mechanism that allows making up for insufficient blood supply in tissues.
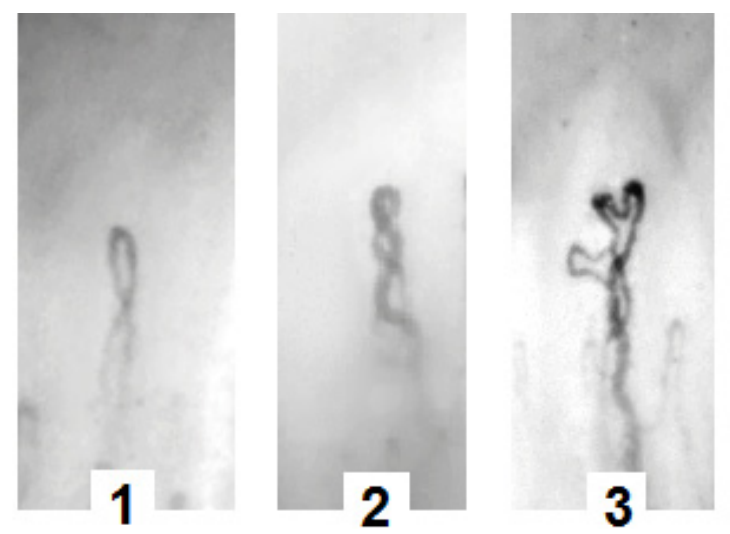

Figure 1. Deformation types observed in capillaries. 1 is a single intersection; 2 is two or more intersections; 3 is a bushy capillary 
According to the obtained data smoking young males also had the greatest number of erythrocytic sludges. When erythrocytes aggregation and disaggregation conform to standards, they support efficient exchange function of blood and stable intravascular pressure [10]. However, pathological occurrence of erythrocytic sludges is accompanied with tissues getting poorer provision with oxygen $[11,12]$. It happens due to aggregation preventing blood cells from entering capillaries and making for bypassing blood flow that doesn't run through capillary networks [13]. In its turn, lower density of functional capillaries leads to a decrease in efficient area of transcapillary exchange [14]. As a number of sludges grows, a mechanism that provides stable pressure in capillaries becomes less and less efficient [15].

We didn't detect any significant differences between two groups as regards temperature of the examined skin area. Mathematical modeling and experiments show that heat exchange with blood flow doesn't occur in capillaries [16]. Therefore, heat emission occurs due to larger vessels, and not capillaries.

Conclusion. We applied computer capillaroscopy to compare parameters of the microcirculatory channel in smoking and non-smoking young males. We detected certain discrepancies, such as shorter capillaries, wider arterial sections and narrower venous sections of capillaries among smoking young males. We obtained parameters of deviations in microvessels, such as capillary deformations and erythrocytic sludges that were more apparent among smoking young males.

These changes are a common basis for microcirculatory disorders in future [17]. It was detected that greater density of capillary networks could be considered as an adaptive sign that allowed making up for insufficient blood supply up to a certain moment.

It is also important to note that when adaptation mechanisms of the microcirculation system are depleted, long-term noncompensated disorders in metabolic processes in any section of the vascular system ultimately result in structural changes; such changes become apparent when a disease occurs.

Taking into account global long-term experience in examining effects produced by smoking on a human body, we can unambiguously state that tobacco smoking is a factor exerting negative influence on health and life quality. However, an extent to which this factor influences blood microcirculation and the structure of this influence require additional research. The results we obtained can enrich a database applied to work out recommendations on preventing smokingrelated diseases and on making young people pursue a healthy lifestyle.

Funding. The research was no granted any financial support.

Conflict of interests. The authors declare there is no any conflict of interests.

\section{References}

1. WHO report on the global tobacco epidemic 2013: enforcing bans on tobacco advertising, promotion and sponsorship. World Health Organization. Geneva, 2013. Available at: https:// www.who.int/tobacco/global_report/2013/en/ (17.10.2018).

2. Cantatore F.P., Corrado A., Covelli M., Lapadula G. Morphologic study of the microcirculation in connective tissue diseases. Ann. Ital. Med. Int., 2000, no. 15, pp. 273-281. Available at: https://www.pubfacts.com/detail/1 1202629/Morphologic-study-of-the-microcirculation-in-connectivetissue-diseases (17.10.2018).

3. Scardina G.A. The effect of cigar smoking on the lingual microcirculation. Odontology, 2005, vol. 93, no. 1, pp. 41-45. DOI: 10.1007/s10266-005-0050-0 
4. De Backer D., Durand A. Monitoring the microcirculation in critically ill patients. Best Practice \& Research Clinical Anaesthesiology, 2014, vol. 28, no. 4, pp. 441-451. DOI: 10.1016/j.bpa.2014.09.005

5. Moore J.P., Dyson A., Singer M., Fraser J. Microcirculatory dysfunction and resuscitation: why, when, and how. British Journal of Anaesthesia, 2015, vol. 115, no. 3, pp. 366-375. DOI: $10.1093 / \mathrm{bja} / \mathrm{aev} 163$

6. Krupatkin A.I., Sidorov V.V. Funktsional'naya diagnostika sostoyaniya mikrotsirkulyatornotkanevykh sistem [Functional diagnostics of microcirculatory and tissue systems]. Moscow, Knizhnyi dom «Librokom» Publ., 2013, 496 p. (in Russian).

7. Dunaev A.V., Sidorov V.V., Krupatkin A.I., Rafailov I.E., Palmer S.G., Stewart N.A., Sokolovski S.G., Rafailov E.U. Investigating tissue respiration and skin microhaemocirculation under adaptive changes and the synchronization of blood flow and oxygen saturation rhythms. Physiological Measurement, 2014, vol. 35, no. 4, pp. 607-621. DOI: 10.1088/0967-3334/35/4/607

8. Shepro D. Microvascular Research: Biology and Pathology. USA, Academic Press Publ., 2005, vol. 1-2, 1296 p.

9. Lambova S., Müller-Ladner U. The role of capillaroscopy in differentiation of primary and secondary Raynaud's phenomenon in rheumatic diseases: a review of the literature and two case reports. Rheumatol. Int., 2009, vol. 29, pp. 1263-1271. DOI: 10.1007/s00296-009-1019-z

10. Stupin V.A., Anikin A.I., Aliev C.R. Transcutaneous oximetry in clinical practice. Moscow, Rossiiskii gosudarstvennyi meditsinskii universitet Publ., 2010, 57 p. Available at: http://diss.seluk.ru/m-physiology/1046293-1-va-stupin-anikin-aliev-transkutannaya-oksimetriya-klinicheskoy-praktike-metodicheskie-rekomendacii-moskva-2010-soderzhanie-vvedenie.php (17.10.2018) (in Russian).

11. Fedorovich A.A. The capillary haemodynamics in eponychium of upper extremity. Regionarnoe krovoobrashchenie i mikrotsirkulyatsiya, 2006, vol. 1, no. 17, pp. 20-29. Available at: https://elibrary.ru/item.asp?id=11715560 (17.10.2018) (in Russian).

12. Borovikov V.P. Statistica. Iskusstvo analiza dannykh na komp'yutere: Dlya professionalov [Statistica. An art of analyzing data on a PC for experts]. Sankt-Peterburg, Piter Publ., 2003, 688 p. Available at: http://computersbooks.net/index.php?id1=4\&category=teoriyaprogramirovaniya\&author= borovikov-v\&book=2003 (17.10.2018) (in Russian).

13. Bishop J.J. Rheological effects of red blood cell aggregation in the venous network: a review of recent studies. Biorheology, 2001, vol. 38, no. 2, pp. 263-274. Available at: https:// www.ncbi.nlm.nih.gov/pubmed/11381180 (17.10.2018).

14. Löfström B. Intravascular aggregation and oxygen consumption: aggregation of red blood cells produced by high molecular weight dextran or by hypothermia. Acta Anaesthesiol. Scand., 1959, vol. 3, no. 1, pp. 41-51. DOI: 10.1111/j.1399-6576.1959.tb00006.x

15. Tateishi N. $\mathrm{O}(2)$ release from erythrocytes flowing in a narrow $\mathrm{O}(2)$-permeable tube: effects of erythrocyte aggregation. Am. J. Physiol. Heart Circ. Physiol., 2001, vol. 281, no. 1, pp. H448-H456. DOI: 10.1152/ajpheart.2001.281.1.h448

16. Popel A.S., Johnson P.C. Microcirculation and hemorheology. Annu. Rev. Fluid. Mech., 2005, no. 37, pp. 43-69. DOI: 10.1146/annurev.fluid.37.042604.133933

17. Schmid-Schönbein H. Microrheology of erythrocytes, blood viscosity, and the distribution of blood flow in the microcirculation. Int. Rev. Physiol., 1976, no. 9, pp. 1-62. DOI: 10.1007/978-3642-66390-1_4

18. Cabel M. Contribution of red blood cell aggregation to venous vascular resistance in skeletal muscle. Am. J. Physiol, 1997, vol. 272, no. 2, pp. H1020-H1032. DOI: 10.1152/ajpheart. 1997.272.2.h1020

19. Luchakov Yu.I., Kamyshev N.G., Shabanov P.D. Heat transfer in blood vessels: comparison experimental and mat. Obzory po klinicheskoi farmakologii i lekarstvennoi terapii, 2009, vol. 7, no. 4, pp. 3-24. Available at: https://cyberleninka.ru/article/n/perenos-tepla-krovyu-sopostavlenie-raschetnyh-i-eksperimentalnyh-dannyh (17.10.2018) (in Russian). 
20. Sokolova I.A. Erythrocyte aggregation. Regionarnoe krovoobrashchenie i mikrotsirkulyatsiya, 2010, vol. 9, no. 4, pp. 4-26. Available at: https://elibrary.ru/item.asp?id=15567994 (17.10.2018) (in Russian).

Kharin A.V., Aver yanova I.V., Vdovenko S.I. Assessing morphofunctional state of microcirculation channel in smoking young males. Health Risk Analysis, 2019, no. 3, pp. 112-117. DOI: 10.21668/health.risk/2019.3.13.eng

Received: 22.10 .2018

Accepted: 08.08.2019

Published: 30.09 .2019 
UDC $613,614,616.9$

DOI: $10.21668 /$ health.risk/2019.3.14.eng

\title{
MULTISEPARATION OF ANTHOCYANINS AND ANTHOCYANIDINS BY HIGH PERFORMANCE LIQUID CHROMATOGRAPHY COMBINED WITH RESPONSE SURFACE METHODOLOGY
}

\author{
Vu Thi Trang ${ }^{1,2}$, Le Hoang Duc ${ }^{2}$, Nguyen Hoai Thu ${ }^{2}$, Le Thi Hong Hao ${ }^{1,2}$, \\ Nguyen Xuan Trung ${ }^{2}$ \\ ${ }^{1}$ National Institute for Food Control, 65 Pham ThanDuat, Hanoi, Vietnam \\ ${ }^{2}$ VNU University of Science, Vietnam National University-Hanoi, 19 Le Thanh Tong, Hanoi, Vietnam
}

\begin{abstract}
A method has been developed for the separation of anthocyanins and anthocyanidins with high performance liquid chromatography (HPLC). Experimental designs were applied for multivariate optimization of the HPLC experimental conditions with using response surface methodology (RSM). Three independent factors, namely formic acid concentration, initial ratio of acetonitrile in gradient program and flow rate, were used to design mathematical models. The responses were resolutions of four peak couples which were the most difficult to separate including: pelargonidin-3-glucoside and delphinidin, delphinidin and peonidin-3-glucoside, peonidin-3-glucoside and malvidin-3-glucoside, peonidin and malvidin. Variance analysis proved a chosen model was highly fit and the RSM method yielded good results in improving separation of anthocyanins and anthocyanidins. The optimized HPLC parameters were as follows: C18 column $(250 \mathrm{~mm} \times 4.6 \mathrm{~mm} \times 5 \mu \mathrm{m})$, mobile phase is FA $10 \%$ and ACN used as a gradient; flow rate $0.8 \mathrm{~mL}$.min-1. Using these optimum conditions, separation of compounds with good resolutions and a run time of less than $30 \mathrm{~min}$ were archived. The results for method validation satisfied the requirement of AOAC, linearity range from $0.2-10 \mathrm{ppm}$ with $R^{2} \geq 0.9955, L O D$ from $0.05-0.1 \mathrm{mg} / \mathrm{kg}, \mathrm{RSD}$ from $4.79-6.45 \%$ and the recovery is from $85.4-109.6 \%$. The method was applied to determone anthocyanins and anthocyanidins in some fruits and vegetables samples with the content of anthocyanidins being from $5.74-218.27 \mathrm{mg} / 100 \mathrm{~g}$. Anthocyanins primarily concentrate in peel of fruits and vegetables, black bean peel contains most anthocyanins.
\end{abstract}

Key words: anthocyanin, anthocyanidin, response surface methodology (RSM), HPLC, antioxidant, chromatography.

Introduction. The anthocyanins are the largest and most important group of watersoluble pigments which are responsible for the blue, purple, red and orange colors of numerous fruits and vegetables. Anthocyanins occur naturally as glycosides of their respective aglycone (anthocyanidin) nucleus with the sugar moiety. The differences between anthocyanins are related to the number of hydroxyl groups, the nature and number of sugars attached to the molecule, the position of these sugars, and the nature and number of aliphatic or aromatic acids attached to the sugars [12]. It is reported that more than 600 different anthocyanins have been found in plant sources [20]. Most of them were formed from the six most common anthocyanidins including cyanidin (Cya), delphinidin
(Del), petunidin (Petu), pelargonidin (Pelar), malvidin (Mal) and peonidin (Peo) [3]. In nature, anthocyanins rarely exist in the free state (unglycosylated) because the lack of electrons in the cationic flavylium makes it very reactive and therefore the molecule is very unstable [13]. Sugar attachment is thought to be of importance for pigment stability. They occur in flower mainly as 3-monoglucosides, 3,5-diglucosides or 3,7-diglycosides [13].

Anthocyanins possess potent antioxidant capacities and health-promoting properties. With such advantages and popularity, anthocyanins and anthocyanidins compounds are replacing artificial food colorants.

The daily intake of anthocyanins in the U.S. diet is estimated to be between 180 and

(C) Vu Thi Trang, Le Hoang Duc, Nguyen Hoai Thu, Le Thi Hong Hao, Nguyen Xuan Trung, 2019

Vu Thi Trang - PhD., candidate, head of Laboratory of Food Quality and Food Additives (e-mail: trang2103@gmail.com; tel.: +84916149106).

Le Hoang Duc - Student (e-mail: duclhd2909@gmail.com; tel.: +84973552366).

Nguyen Hoai Thu - Student (e-mail: nguyenhoaithu2596@gmail.com; tel.: +84359673139).

Le Thi Hong Hao - PhD., general director (e-mail: lethihonghao@yahoo.com; tel.: +84904248167).

Nguyen Xuan Trung - PhD., lecturer (e-mail: trungnx2004@,gmail.com; tel.: +84904303513). 
$215 \mathrm{mg}$, whereas the intake of other dietary flavonoids such as genistein, quercetin or andapigenin is only 20-25 mg.day ${ }^{-1}$ [15]. Anthocyanins are postulated to act as antioxidants by donating hydrogen atoms to form highly reactive free radicals [5].

There are numbers of methods applied to determine anthocyanins or anthocyanidins such as UV-Vis [2], HPLC [19, 11, 9], LC-MS $[7,8,23,1]$ or $\mathrm{CE}[17,6]$. However, the published studies usually applied these techniques to determine the total content of anthocyanins or anthocyanidins. It has been reported that a simultaneous determination of anthocyanin glucosides and anthocyanidin aglycones is challenged due to different polarities between the anthocyanin glucoside group and the anthocyanidin aglycone group [18]. Therefore, this study focused on the multi-separation of twelve anthocyanins and anthocyanidins by HPLC combined with response surface methodology.

Experimental. Materials and reagents. Anthocyanidins standards including Delphinidin chloride, cyanidin chloride, pelargonidin chloride, peonidin chloride and malvidin chloride were provided by Sigma Aldrich. Petunidin chloride was provided by Chromadex. Anthocyanins standards: Pelargonidin - 3 - glucoside (Pelar-3-G), cyaniding - 3 - glucoside (Cya-3-G), peonidin 3 - glucoside (Peo-3-G) and malvidin - 3 glucoside (Mal-3-G) were purchased from Sigma - Aldrich. Delphinidin - 3 - glucoside (Del-3-G) and Petunidin - 3 - Glucoside (Petu-3-G) are from Chromadex. All other reagents and chemicals were of analytical or HPLC grade from Merck.

Several fruits and vegetables (red apple, purple potato, black grape, black bean, etc.) were randomly collected from the markets and supermarkets in Hanoi, Vietnam, and analyzed using the optimized method.

Apparatus and procedures. All experiments were conducted on a Shimadzu LC 20AD series liquid chromatography equipped with a vacuum degasser, binary pump, autosampler, column oven and photodiode array detector. Instrument control and data acquisi- tion and analysis were performed through LC Solution software.

Separation was achieved on a Sun Fire $\mathrm{C}_{18}$ column $250 \mathrm{~mm} \times 4.6 \mathrm{~mm}, 5 \mu \mathrm{m}$ with a guard column. The injection volume was $20 \mu \mathrm{L}$ with PDA detection at $520 \mathrm{~nm}$. The elution solvents were formic acid in water and acetonitrile at specific compositions.

A homogenized sample was weighted into a heat-resistant flask. $30 \mathrm{~mL}$ of methanol was then added to the flask. The solution was extracted at $100^{\circ} \mathrm{C}$ during $30 \mathrm{~min}$. After cooling, the extract was diluted and filtered by using $0.45 \mu \mathrm{m}$ membrane. Obtained solution was finally analyzed on HPLC system with PDA detector for anthocyanin.

For anthocyanidin detection, the anthocyanin extract was added with concentrated hydrochloric acid to reach hydrochloric acid concentration of $2.4 \mathrm{M}$ and heated in water bath at $90^{\circ} \mathrm{C}$ in $60 \mathrm{~min}$. After cooling to the room temperature, the solution was diluted by adding methanol, filtered and analyzed on HPLC system with PDA detector for anthocyanidin.

Data analysis. The data analysis was performed using Design-Expert Version 10.0.7 statistical software (Stat-Ease Inc., Minneapolis, MN, USA). Factor significance was calculated using such a statistical tool as analysis of variance (ANOVA) that was estimated and run up to the first order interaction terms. For all the calculation, it was assumed that higher order interaction terms did not contribute significantly to the behavior of the selected statistical model, since the chances of these interactions happening are low.

Method validation. The optimized method was validated with the following parameters: linearity and range, precision, accuracy, and limit of detection and quantitation. The results were verified according to AOAC strict validation guidelines.

Results and discussions. Selection of HPLC analytical conditions. Due to the polarity of anthocyanins and anthocyanidins the nonpolar column $\mathrm{C}_{18}$ was chosen as the separate column. It was reported that the anthocyanidins and anthocyanins were eluted by ace- 
tonitrile (ACN) and acid, such as: formic acid (FA) concentration of $0.05-10 \%$, trifluoroacetic acid (TFA) concentration of $0.05-0.1 \%$, phosphoric acid $0.3-4 \%$, and hydrochloric acid $5 \mathrm{mM}[10,14,16,4,21,22]$. In particular, FA and TFA acid were commonly used because organic acids increase the signal and should be added to water as eluent. The use of inorganic acids such as hydrochloric acid or phosphoric acid at high concentrations could affect the chromatographic column performance. Therefore, in this study FA and TFA were selected to investigate the separation of anthocyanidins and anthocyanins.

Preliminary experiments showed that using TFA $0.1 \%$ produced sharp, symmetrical but overlapped peaks, while FA $0.1 \%$ completely separated the peaks. On the other hand, as FA is a weaker acid than TFA, it was possible to increase FA concentration to obtain higher sensitivity (sharper peak). Therefore, FA was chosen for optimizing the separation.

Due to the different polarities, anthocyanidins and anthocynins interact differently with stationary phases. When eluting in an isocratic mode they could be completely separated from each other, but there is still a possibility that the analysis time lasts approximately 50 to 60 minutes and the signal could be significantly low. For this reason, it is necessary to change the ratio of the mobile phase composition to the gradient program.

In addition, the flow rate could strongly affect the elution capacity, the amount of solvent consumed, and the analysis time. For the $\mathrm{C}_{18}$ column $(250 \mathrm{~mm} \times 4.6 \mathrm{~mm} \times 5 \mu \mathrm{m})$ the flow rate was selected in the range of $0.6-1.0 \mathrm{~mL} / \mathrm{min}^{-1}$

In this part, investigates were archived to find out a condition in which the resolution of 4 couples of peaks (Pelar-3-G and Del, Del and Peo-3-G, Peo-3-G and Mal-3G, Peo and Mal) was larger than 2 for a good determination.

Optimization of analytical factors by RSM. RSM is a collection of mathematical and statistical techniques for empirical model building. By careful design of experiments, the objective is to optimize a response (output variable) which is influenced by several independent variables (input variables). An experiment is a series of tests, called runs, in which changes are made in the input variables in order to identify the reasons for changes in the output response.

In order to determine simultaneously twelve anthocyanins and anthocyanidins, a proper separation between them was absolutely important. Hence, it was necessary to find a condition in which the peaks were separated completely, it means that the resolutions of peaks were large enough (normally larger than 2). Aquadratic central composite designwas used with 3 independent factors, including the concentration of FA in mobile phase $\left(\mathrm{X}_{1}\right)$, the initial ratio of $A C N$ in the gradient $\left(\mathrm{X}_{2}\right)$, and the flow rate $\left(\mathrm{X}_{3}\right)$. The responses were the resolutions of peaks that are usually small. According to our preliminary results, four responses were selected as follows: the resolution between Pelar-3-G and Del $\left(\mathrm{Y}_{1}\right)$, Del and Peo-3-G $\left(\mathrm{Y}_{2}\right)$, Peo-3-G and Mal-3-G $\left(\mathrm{Y}_{3}\right)$, and Peo and Mal $\left(\mathrm{Y}_{4}\right)$.

The number of experiments performed on the quadratic central composite matrix was calculated by the following formula:

$$
N=N_{\mathrm{o}}+N^{*}+N_{\mathrm{c}},
$$

where:

$\mathrm{N} *$ is a number of experiments at point *, $\mathrm{N}^{*}=2 \mathrm{n}$

$\mathrm{N}_{\mathrm{c}}$ is a number of experiments at center, $\mathrm{N}_{0}>1$

$\mathrm{N}_{\mathrm{o}}$ is a number of experiments at origin, $\mathrm{N}_{o}=2^{\mathrm{n}-\mathrm{q}}$ ( $\mathrm{n}$ is a number of factors, $\mathrm{q}$ is a number of reduced factors)

For $\mathrm{n}=3, \mathrm{q}=0$, we have the following: $\mathrm{N}^{*}=6 ; \mathrm{N}_{\mathrm{o}}=8 ; \mathrm{N}_{\mathrm{c}}=6$

Thus, the total number of experiments proceeded $\mathrm{N}=20$ with 6 repeated experiments at the center and the distance from the origin to the point $*$ is $d=2^{(n-q) / 4}=1.682$.

By using the Design Expert software, the quadratic response with three factors was evaluated and the results are given in Table 1.

Table 1

The base levels of 3 factors with their codes

\begin{tabular}{|l|c|c|c|}
\hline \multirow{2}{*}{ Factors } & \multicolumn{3}{|c|}{ Level } \\
\cline { 2 - 4 } & -1 & 0 & +1 \\
\hline$X_{1}$ (concentration of FA, \% v/v) & 5 & 10 & 15 \\
\hline$X_{2}$ (initial ratio of ACN, \%) & 1 & 6,5 & 12 \\
\hline$X_{3}$ (flow rate, mL.min-1) & 0,6 & 0,8 & 1,0 \\
\hline
\end{tabular}


The design matrix as well as the corresponding resolution values are given in Table 2 . All experiments were performed in randomized order to minimize the effects of uncontrolled variables that may introduce a bias in the measurements.

By postulating a fitted full quadratic model described in Eq. (1), the mathematical models were obtained for each response $\left(\mathrm{Y}_{\mathrm{i}}\right)$ in terms of coded factors after fitting Eq. (1) by the least square regression, see Table 3.

$$
Y_{i}=b_{0}+\sum_{i=1}^{k} b_{i} x_{i}+\sum_{1 \leq i \leq j}^{k} b_{i j} x_{i} x_{j}+\sum_{i=1}^{k} b_{i i} x_{i}^{2}
$$

Where $\mathrm{k}$ is the number of factors (variables); $\mathrm{b}_{0}$ is the intercept parameter; and $b_{i}, b_{i j}$ and $b_{i i}$ are the regression parameters for linear, interaction, and quadratic effects of each factor $\mathrm{x}_{\mathrm{i}}$, respectively.

Table 2

Experimental design matrix of coded variables and studied responses

\begin{tabular}{|c|c|c|c|c|c|c|c|c|}
\hline \multirow{2}{*}{$\begin{array}{c}\text { Std. } \\
\text { Ord. }\end{array}$} & Run & \multicolumn{3}{|c|}{ Coded variable } & \multicolumn{4}{c|}{ Response } \\
\cline { 3 - 8 } & Ord. & $X_{1}$ & $X_{2}$ & $X_{3}$ & $Y_{1}$ & $Y_{2}$ & $Y_{3}$ & $Y_{4}$ \\
\hline 19 & 1 & 10 & 6,5 & 0,8 & 2,641 & 3,483 & 2,344 & 2,696 \\
\hline 3 & 2 & 5,0 & 12 & 0,6 & 5,044 & 0,468 & 4,525 & 2,394 \\
\hline 15 & 3 & 10 & 6,5 & 0,8 & 2,637 & 3,609 & 2,381 & 2,717 \\
\hline 4 & 4 & 15 & 12 & 0,6 & 1,838 & 1,566 & 3,206 & 3,415 \\
\hline 9 & 5 & 1,6 & 6,5 & 0,8 & 1,589 & 0,729 & 3,227 & 1,601 \\
\hline 1 & 6 & 5,0 & 1,0 & 0,6 & 1,229 & 0,000 & 0,548 & 0,140 \\
\hline 8 & 7 & 15 & 12 & 1,0 & 2,271 & 2,272 & 2,988 & 3,122 \\
\hline 10 & 8 & 18,4 & 6,5 & 0,8 & 0,685 & 3,040 & 3,345 & 3,549 \\
\hline 7 & 9 & 5,0 & 12 & 1,0 & 4,479 & 0,611 & 3,522 & 2,579 \\
\hline 20 & 10 & 10 & 6,5 & 0,8 & 2,641 & 3,483 & 2,344 & 2,696 \\
\hline 6 & 11 & 15 & 1,0 & 1,0 & 1,527 & 3,010 & 2,593 & 3,438 \\
\hline 11 & 12 & 10 & 0,0 & 0,8 & 1,250 & 0,832 & 0,717 & 2,495 \\
\hline 14 & 13 & 10 & 6,5 & 1,1 & 2,663 & 3,500 & 2,143 & 2,405 \\
\hline 12 & 14 & 10 & 15,7 & 0,8 & 4,560 & 0,000 & 3,878 & 3,639 \\
\hline 13 & 15 & 10 & 6,5 & 0,5 & 2,669 & 1,271 & 1,817 & 0,943 \\
\hline 5 & 16 & 5,0 & 1,0 & 1,0 & 0,000 & 1,673 & 0,997 & 1,932 \\
\hline 16 & 17 & 10 & 6,5 & 0,8 & 2,630 & 3,438 & 2,325 & 2,717 \\
\hline 18 & 18 & 10 & 6,5 & 0,8 & 2,639 & 3,430 & 2,326 & 2,695 \\
\hline 2 & 19 & 15 & 1,0 & 0,6 & 1,436 & 0,877 & 1,382 & 2,427 \\
\hline 17 & 20 & 10 & 6,5 & 0,8 & 2,625 & 3,462 & 2,338 & 2,713 \\
\hline
\end{tabular}

Table 3

Refined regression equations and statistical parameters for studied responses from the experimental design

\begin{tabular}{|c|c|c|c|c|c|}
\hline Response & Regression equations $^{\mathrm{a}}$ & $\begin{array}{c}\mathrm{C} . \mathrm{V} . \\
(\%)\end{array}$ & $\begin{array}{c}\text { Adjusted } \\
\mathrm{R}^{2}\end{array}$ & $\begin{array}{c}\text { Predicted } \\
\mathrm{R}^{2}\end{array}$ & $\begin{array}{c}\text { Adequate } \\
\text { precision }\end{array}$ \\
\hline$Y_{1}^{\mathrm{c}}$ & $\begin{array}{c}Y_{1}=2,72-0,38 X_{1}+1,10 X_{2}-0,094 X_{3}- \\
-0,89 X_{1} X_{2}+0,29 X_{1} X_{3}-0,54 X_{1}^{2}\end{array}$ & 9,22 & 0,9707 & 0,9286 & 37,040 \\
\hline$Y_{2}$ & $\begin{array}{c}Y_{2}=3,49+0,65 X_{1}-0,15 X_{2}+0,62 X_{3}+0,13 X_{1} X_{3}- \\
-0,37 X_{2} X_{3}-0,59 X_{1}{ }^{2}-1,11 X_{2}^{2}-0,42 X_{3}^{2}\end{array}$ & 7,35 & 0,9878 & 0,9628 & 34,651 \\
\hline$Y_{3}^{\mathrm{c}}$ & $\begin{array}{c}Y_{3}=2,32+0,057 X_{1}+1,03 X_{2}+0,072 X_{3}-0,54 X_{1} X_{2}+ \\
+0,19 X_{1} X_{3}-0,36 X_{2} X_{3}+0,32 X_{1}{ }^{2}-0,14 X_{3}^{2}\end{array}$ & 4,12 & 0,9904 & 0,9705 & 57,652 \\
\hline$Y_{4}$ & $\begin{array}{c}Y_{4}=2,67+0,63 X_{1}+0,40 X_{2}+0,38 X_{3}-0,28 X_{1} X_{2}- \\
-0,16 X_{1} X_{3}-0,36 X_{2} X_{3}+0,13 X_{2}{ }^{2}-0,36 X_{3}^{2}\end{array}$ & 4,44 & 0,9830 & 0,9433 & 46,720 \\
\hline
\end{tabular}

${ }^{\text {a }}$ Obtained by applying backward elimination tool to remove nonsignificant $(\mathrm{P}>0.05)$ terms from the full models

${ }^{\mathrm{b}}$ Coefficient of variation

${ }^{\mathrm{c}}$ The nonsignificant terms $\mathrm{X}_{3}\left(\right.$ in $\left.\mathrm{Y}_{1}\right), \mathrm{X}_{1}$ (in $\mathrm{Y}_{3}$ ) were included in the equation to maintain model hierarchy. 
As there are potential problems associated with the normality assumption, unequal error variance by treatment or block, and block treatment interaction, the adequacy of the assumed model needs to be examined. In this study, adequacy checking of ultimate refined models was carried out using the adequate precision statistic tool and normal probability plots of the residuals. "Adequate Precision" measures the signal to noise ratios. A ratio greater than 4 is desirable. The ratios of $37.040,34.651,57.652$, and 46.720 indicate adequate signals. This model can be used to navigate the design space. Besides that, a fitted model is usually evaluated with a coefficient of determination, $\mathrm{R}^{2}$. A concern with this statistic value is that it always increases when terms are added to the model, even if the terms are not significant. Therefore, it is usually smaller for the refined model than the corresponding full model. To overcome the disadvantages associated with the use of $\mathrm{R}^{2}$, adjusted coefficients, adjusted $\mathrm{R}^{2}$, are used. Consequently, to get a simpler but more accurate model, the nonsignificant terms $(P>0.05)$ were removed from the models. Although the main effect $\mathrm{X}_{3}$ was not a significant term in models corresponding to $Y_{1}$, and $X_{1}$ was not a significant term in models corresponding to $\mathrm{Y}_{3}$ to comply with the model hierarchy, it was included in the resulting equations. In addition, the values fell within the reasonable agreement with predicted $\mathrm{R}^{2}$ and within the acceptable limits of $\mathrm{R}^{2} \geq 0.80$, indicating that the data showed good fit with the second-order polynomial equations. The values of model $\mathrm{F}$ implied that all four models were significant. There was only a $0.01 \%$ chance that an F-value this large could occur due to noise. The values obtained for the coefficient of variation (C.V.) percent, which measures the reproducibility of a model, were less than $10 \%$ (from $4.12 \%$ to $9.22 \%$ ).

As we can see in Table 3 and Figure 1, the factors had very different effects on responses. Concentration of formic acid and flow rate made positive effects on responses $\mathrm{Y}_{2}, \mathrm{Y}_{3}, \mathrm{Y}_{4}$ but negative effects on response $Y_{1}$. Concentration of acetonitrile made positive effects on responses $Y_{1}, Y_{3}, Y_{4}$ but negative effects on response $Y_{2}$. For $Y_{1}$ resolution (pelar-3-G and Del), $\mathrm{Y}_{3}$ resolution (Peo-3-G and Mal-3-G), the term $X_{2}$ had the most significant effect on separation. These resolutions were increased by $\mathrm{X}_{2}$. Interaction of formic acid and acetonitrile increased the resolutions, while interaction of acetonitrile and flow rate decreased them. Almost square terms had negative effects. The flow rate had little effect on the responses than the other two, possibly due to the limited operating range.

Figure 1B showed the effect of formic concentration and flow rate in the resolution of Peo and Mal by keeping acetonitrile ratio at $6.5 \%$. As we can see, increasing both formic acid concentration and flow rate led to a gradual increase in the resolution. This can be explained by anthocyanins and anthocyanidins being stable at $\mathrm{pH}<3$. A higher acid concentration and lower $\mathrm{pH}$ level could raise the percentage of flavylium cation and increase the peak area and resolution. However, high organic acids could increase the polarity of the mobile phase, resulting in weaker power of elution and thus a longer retention time. Subsequent reduction in the retention time could be attributed to a competitive interaction between formic acid molecules and the polar groups of anthocyanins for the silanol group on the alkyl silica surface when excessive organic acid was added.

When a simple response is being analyzed, model analysis indicates areas in the design region where the process is likely to give desirable results. Many response surface problems involve the analysis of several responses. Meanwhile, simultaneous consideration of multiple responses involves building an appropriate response surface model for each response and finding a set of operating conditions that in some senses optimizes 


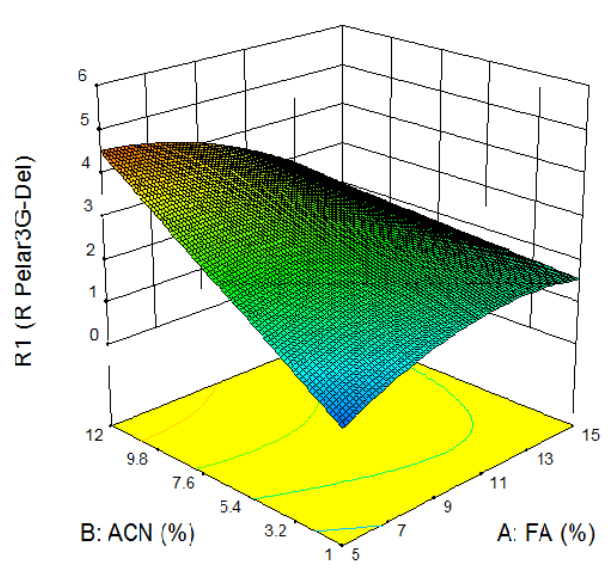

(A) The resolution of Pelar-3-G and Del as a function of acetonitrile ratio and formic concentration

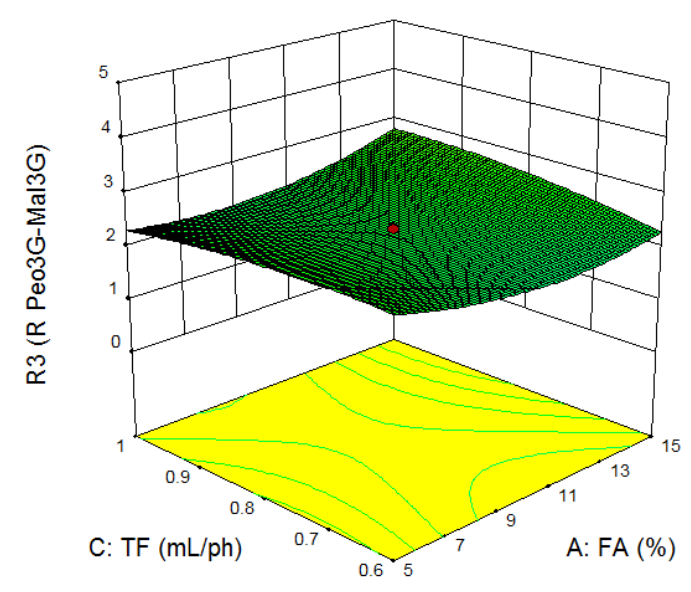

(C) The resolution of Peo-3-G and Mal-3-G as a function of flow rate and formic concentration

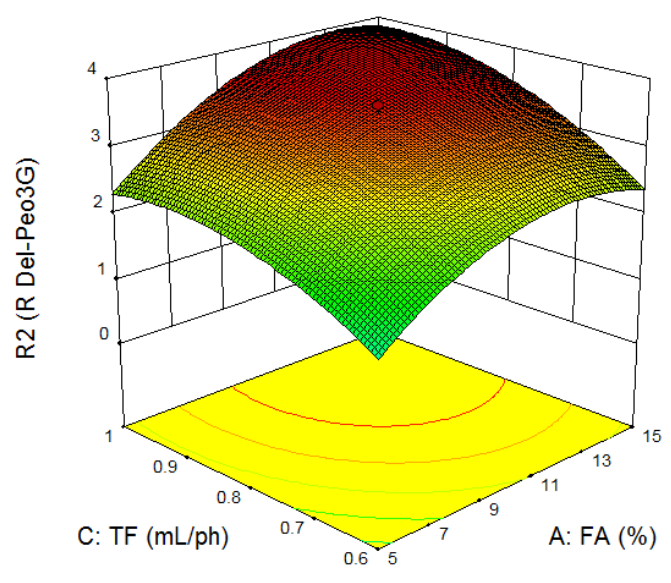

(B) The resolution Del and Peo-3-G as a function of flow rate and formic concentration

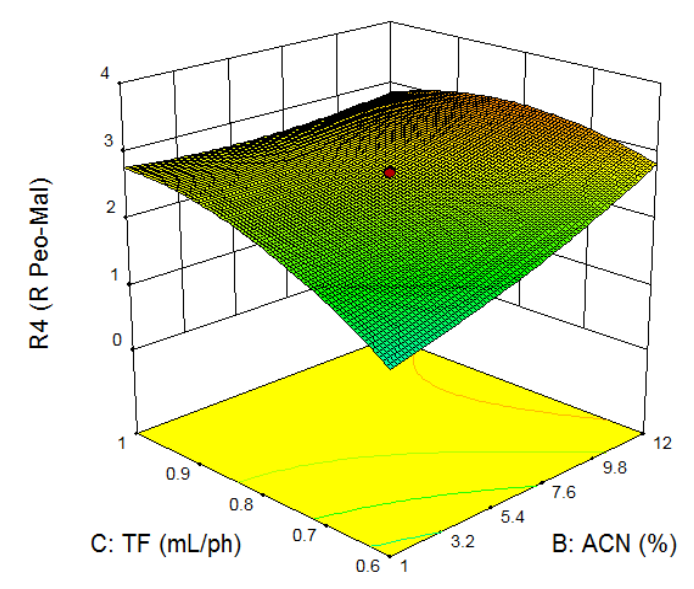

(D) The resolution of Peo and Mal as a function of flow rate and acetonitrile ratio

Figure 1. Response surface plots representing the responses

all responses or at least keeps them within a desired range. Settings for multi-criteria optimization of the individual factors and responses were showed in Table 4.

The goals were combined employing this strategy into an overall desirability function and the global desirability for the optimal solution was determined to be 0.748 . Following the conditions and restrictions discussed, the optimal calculated parameters were obtained as: formic acid concentration of $10 \%$, acetonitrile ratio of $10 \%$ and flow rate of 0.80 mL.min-1.
Table 4

Settings for multi-criteria optimization of the individual factors and responses

\begin{tabular}{|c|c|c|c|c|}
\hline $\begin{array}{c}\text { Factor/ } \\
\text { Response }\end{array}$ & Goal & $\begin{array}{c}\text { Lower } \\
\text { limit }\end{array}$ & $\begin{array}{c}\text { Upper } \\
\text { limit }\end{array}$ & Importance \\
\hline$X_{1}$ & In range & 5 & 10 & 3 \\
\hline$X_{2}$ & Inrange & 1 & 12 & 3 \\
\hline$X_{3}$ & Target $=1$ & 0,6 & 1 & 3 \\
\hline$Y_{1}$ & Maximum & 0 & 5,044 & 2 \\
\hline$Y_{2}$ & Maximum & 0 & 3,609 & 5 \\
\hline$Y_{3}$ & Maximum & 0 & 4,525 & 5 \\
\hline$Y_{4}$ & Maximum & 0 & 3,639 & 4 \\
\hline
\end{tabular}




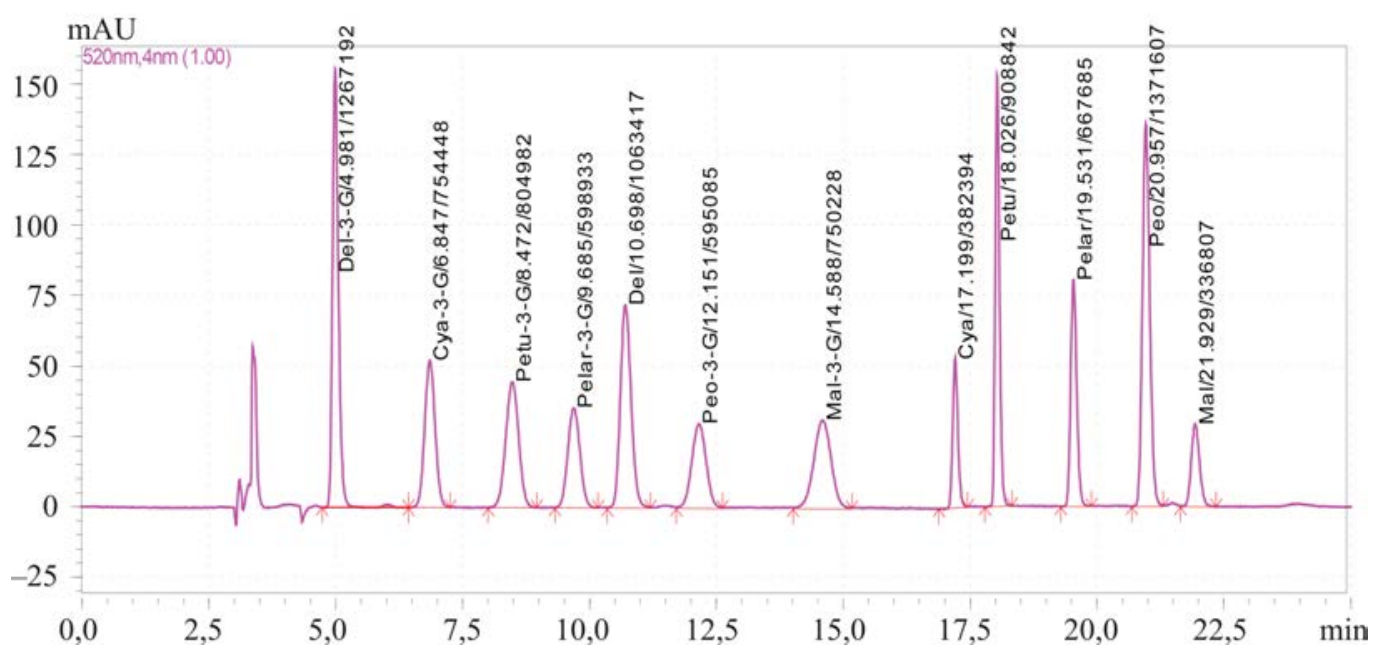

Figure 2.Chromatogram of twelve anthocyanin and anthocyanidin at optimized conditions. The elution order was as follow: (1) Del-3-G, (2) Cya-3-G, (3) Petu-3-G, (4) Pelar-3-G,

(5) Del, (6) Peo-3-G, (7) Mal-3-G, (8) Cya, (9) Petu, (10) Pelar, (11) Peo, (12) Mal.

The optimized HPLC parameters: C18 Sun Fire column by Waters $(250 \mathrm{~mm} \times 4.6 \mathrm{~mm} \times$ $5 \mu \mathrm{m})$, mobile phase was FA $10 \%$ and $\mathrm{ACN}$ using a gradient: starting at $10 \% \mathrm{ACN}$, linearity increasing from $10-12 \% \mathrm{ACN}$ in $0-10$ minutes, constant at $19 \%$ ACN from $10.01-$ 21 minutes, constant at $10 \% \mathrm{ACN}$ in $21.01-$ 25 minutes for the next analysis; flow rate: 0.8 mL.min-1. Fig. 2 was the chromatogram of multi-separation anthocyanins and anthocyanidins with good resolutions.

Method validation. Calibration curve of anthocyanins and anthocyanidins was established in the concentration range of $0.2-10$ $\mathrm{mg} / \mathrm{L}$ with the correlation coefficient $>0.9955$. Limit of detection was determined by gradually spiking small amounts of standard solution into blank samples until getting the signal over noise equal to 3 . The results showed that HPLC-PDA method provided a good sensitivity for the determination of anthocyanins and anthocyanidins with LOD of $0.05-0.1 \mathrm{mg} / \mathrm{kg}$. Precision was assessed by six replicates in some sample matrixes. RSD was from $4.79-6.45 \%$. The recovery was determined by spiking standards into plum, sweet potato samples with three different levels. Assays were performed in three replicates at each added concentration. The recoveries between
$85.4 \%$ and $109.6 \%$ have been obtained. The method satisfied the requirement of recovery for corresponding analyte concentration according to AOAC.

Analysis of the marketed products. The samples were collected randomly from the markets and supermarkets in Hanoi. After homogenizing, the samples were analyzed by the procedure as mentioned above.

After the extraction, almost anthocyanins were transformed to anthocyanidins. The anthocyanins content before the hydrolysis and anthocyanidins content after the hydrolysis of some fruits were given in Tables 5 and Figure 3.

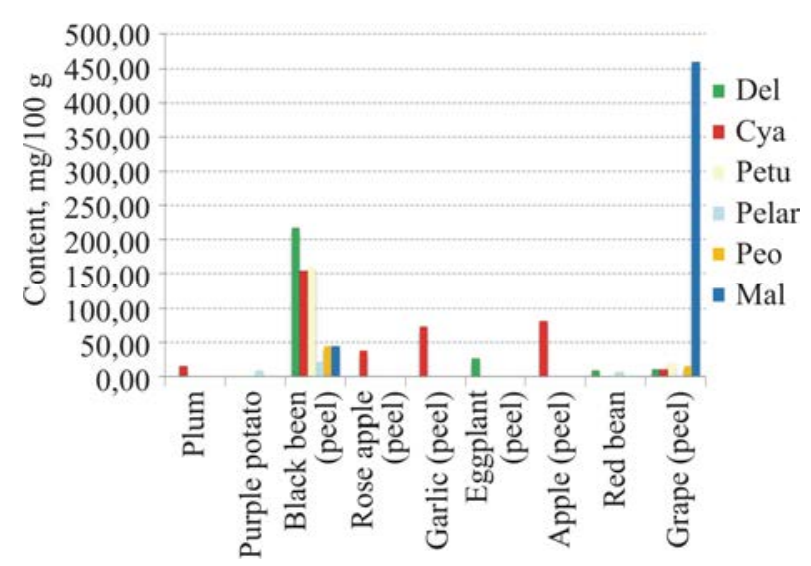

Figure 3. The anthocyanidins contents in marketed products 
Table 5 thocyanidins and also had the highest total con-

Anthocyanins content in the marketed products

\begin{tabular}{|l|c|c|c|c|}
\hline \multicolumn{1}{|c|}{ Samples } & \multicolumn{4}{|c|}{ Content (mg/100g) } \\
\hline Plum & Cya-3-G & Pelar-3-G & Peo-3-G & Mal-3-G \\
\hline $\begin{array}{l}\text { Purple } \\
\text { potato }\end{array}$ & 1.57 & - & - & - \\
\hline $\begin{array}{l}\text { Black bean } \\
\text { (peel) }\end{array}$ & - & 1.05 & - & - \\
\hline $\begin{array}{l}\text { Rose apple } \\
\text { (peel) }\end{array}$ & 18.67 & - & 8.28 & 19.30 \\
\hline Garlic (peel) & 11.23 & - & - & - \\
\hline $\begin{array}{l}\text { Eggplant } \\
\text { (peel) }\end{array}$ & 8.4 & - & - & - \\
\hline Apple (peel) & - & - & - & - \\
\hline Red bean & 27.17 & - & - & - \\
\hline Grape (peel) & 1.76 & 7.40 & - & - \\
\hline
\end{tabular}

Accordingly, the anthocyanidins content was much higher than the anthocyanins-3glucoside content, so, there were other types of anthocyanins in the samples excluding anthocyanins-3-glucoside. Among them, cyanidin-3glucoside was the most appeared anthocyanin in fruits and vegetables, other anthocyanins were found in a less extent. In addition, cyanidin was the most common anthocyanidin, which occurs in almost sample, following by delphinidin.

Black bean peel had the biggest diversity of anthocyanidins with all 6-most-common an- tent, reaching more than $600 \mathrm{mg}$ anthocyanidins in $100 \mathrm{~g}$ sample. Grape peel also contained a high total content of anthocyanidins, with the majority was malvidin, which reaches more than $450 \mathrm{mg} / 100 \mathrm{~g}$. Plum, rose apple peel, garlic peel and apple peel contained only cyanidin. Purple potato and eggplant contained only pelargonidin and delphinidin, respectively.

Conclusions. The main contribution of this study was to use experimental design to find optimal HPLC conditions for simultaneous separation twelve anthocyanins and anthocyanidins. The mathematical models developed for relating resolutions to the composition of the mobile phase proved to be an efficient strategy for optimization of the chromatographic method. A significant good fit with the models was found between predicted and observed data, which means the method was suitable for the analysis of the compounds. This method allows simultaneous determination of anthocyanins and anthocyanidins in fruits and vegetables samples in a short time, with a high selectivity and sensitivity. The procedure is simple, and the cost is also reasonable.

Funding. The research was not granted any sponsor support.

Conflict of interests. The authors state there is no any conflict of interests.

\section{References}

1. Bordonaba J.G., Crespo P., Terry L.A. A new acetonitrile-free mobile phase for HPLC-DAD determination of individual anthocyanins in blackcurrant and strawberry fruits: A comparison and validation study. Food Chemistry, 2011, no. 129, pp. 1265-1273. DOI: 10.1016/j.foodchem.2010.09.114

2. Deineka V.I., Deineka L.A., Saenko I.I. Regularities of Anthocyanins Retention in RP HPLC for «Water-Acetonitrile-Phosphoric Acid Mobile» Phases. Journal of Analytical Methods in Chemistry, 2015, vol. 1, pp. 6. DOI: 10.1155/2015/732918

3. Castañeda-Ovando A., Pacheco-Hernández L., Paez E., Rodríguez J.A., Galan-Vidal C.A. Chemical studies of anthocyanins: A review. Food Chemistry, 2009, vol. 113, pp. 859-871. DOI: 10.1016/j.foodchem.2008.09.001

4. Casteele K.V. [et al.]. Separation of some anthocyanidins, anthocyanins, proanthocyanidins and related subtances by reversed phase high performance liquid chromatography. Journal of chromatography, 1983, vol. 259, pp. 291-300.

5. Hertog M.G., Hollman P.C., Katan M.B., Kromhout D. Intake of potentially anticarcinogenic flavonoids and their determinants in adults in The Netherlands. Nutr. Cancer, 1993, no. 20, pp. 21-29. DOI: $10.1080 / 01635589309514267$ 
6. Catherine A.R., Nicholas J.M., George P. Structure-antioxidants activity relationships of flavonoids and phenolic acids. Free Radical Biology \& Medicine, 1996, no. 20, pp. 933-956. DOI: 10.1016/0891-5849(95)02227-9

7. Lee J., Wrolstad R.E., Durst R. AOAC Official Method 2005.02 Total Monomeric Anthocyanin Pigment Content of Fruit Juices, Beverages, Natural Colorants, and Wines pH Differential Method. Official Methods of Analysis of AOAC International, 2005, chapter 37, pp. 37-39.

8. Cesa S., Carradori S., Bellagamba G., Locatelli M., Antonietta Casadei M., Masci A., Paolicelli P. Evaluation of processing effects on anthocyanin content and colour modifications of blueberry (Vaccinium spp.) extracts: Comparison between HPLC-DAD and CIELAB analyses. Food Chemistry, 2017, no. 232, pp. 114-123. DOI: 10.1016/j.foodchem.2017.03.153

9. Fibigr J., Satínsky D., Solich P. A UHPLC method for the rapid separation and quantification of anthocyanins in acai berry and dry blueberry extracts. Journal of Pharmaceutical and Biomedical Analysis, 2017, no. 143, pp. 204-213. DOI: 10.1016/j.jpba.2017.05.045

10. Canuto G.A.B., Oliveira D.R., Da Conceição L.S.M., Farah J.P.S., M.F.M. Tavare. Development and validation of a liquid chromatography method for anthocyanins in strawberry (Fragaria spp.) and complementary studies on stability, kinetics and antioxidant power. Food Chemistry, 2016, no. 192, pp. 566-574. DOI: 10.1016/j.foodchem.2015.06.095

11. Li D., Li B., Ma Y., Sun X., Lin Y., Meng X. Polyphenols, anthocyanins, and flavonoids contents and the antioxidant capacity of various cultivars of highbush and half-high blueberries. Journal of Food Composition and Analysis, 2017, no. 62, pp. 84-93. DOI: 10.1016/j.jfca.2017.03.006

12. Trikas E.D., Melidou M., Papi R.M., Zachariadis G.A., Kyriakidis D.A. Extraction, separation and identification of anthocyanins from red wine by-product and their biological activities. Journal of functional food , 2016, no. 25, pp. 548-558.

13. Huang Zh., Wang B., Williams P., Pace R.D. Identification of anthocyanins in muscadine grapes with HPLC-ESI-MS. Food Science and Technology, 2009, no. 42, pp. 819-824. DOI: 10.1016/j.lwt.2008.11.005

14. Ruiz A., Hermosín-Gutiérrez I., Vergara C., Von Baer D., Zapata M., Hitschfeld A., Obando L., Mardones C. Anthocyanin profiles in south Patagonian wild berries by HPLC-DAD-ESI-MS/MS. Food Research International, 2013, no. 51, pp. 706-713. DOI: 10.1016/j.foodres.2013.01.043

15. Bridle P., Garcia-Viguera C., Tomas-Barberan F.A. Analysis of Anthocyanins by Capillary Zone Electrophoresis. Journal of Liquid Chromatography \& Related Technologies, 1996, vol. 19, no. 4, pp. 537-545. DOI: 10.1080/10826079608005518

16. Caboni M.F., Comandini P., Giampaolo B., Cardinali A., Cerretani L. CZE separation of strawberry anthocyanins with axitic buffer and comparison with HPLC. Journal of separatrion of science, 2008, no. 31, pp. 3257-3264. DOI: 10.1002/jssc.200800199

17. Shim Y., Kim S., Seo D., Park H., Ha J. Rapid method for determination of anthocyanin glucosides and free delphinidin in grapes using u-HPLC. Journal of Chromatographic Science, 2014, no. 52, pp. 629-635. DOI: 10.1093/chromsci/bmt091

18. Gao L., Mazza G. Rapid Method for Complete Chemical Characterization of Simple and Acylated Anthocyanins by High-Performance Liquid Chromatography and Capillary Gas-Liquid Chromatography. Journal of Agricultural and Food Chemistry, no. 42, pp. 118-125. DOI: 10.1021/jf00037a020

19. Liu X., Mu T., Sun H., Zhang M., Chen J. Optimisation of aqueous two-phase extraction of anthocyanins from purple sweet potatoes by response surface methodology. Food Chemistry, 2013, no. 141, pp. 3034-3041. DOI: 10.1016/j.foodchem.2013.05.119

20. Nyman N.A., Kumpulainen J.T. Determination of anthocyanidins in berries and red wine by high-performance liquid chromatography. Journal of Agricultural and Food Chemistry, 2001, no. 49, pp. 4183-4187. DOI: 10.1021/jf010572i

21. Deividas B., Ivanauskas L., Dirse V. Study of diversity of anthocyanin composition in bilberry (Vaccinium myrtillus L.) fruits. Meditsina (Kaunas, Lithuania), 2007, vol. 43 no. 12, pp. 971-977. 
22. Welch C., Wu Q., Simon J. Recent Advances in Anthocyanin Analysis and Characterization. Current Analytical Chemistry, 2008, vol. 4, no. 2, pp. 75-101. DOI: 10.2174/157341108784587795

23. Zhang Zh., Kou X., Fugal K. Comparison of HPLC Methods for Determination of Anthocyanins and Anthocyanidins in Bilberry Extracts. Journal of Agricultural and Food Chemistry, 2004, no. 52, pp. 688-691. DOI: 10.1021/jf034596w

Vu Thi Trang, Le Hoang Duc, Nguyen Hoai Thu, Le Thi Hong Hao, Nguyen Xuan Trung. Multiseparation of anthocyanins and anthocyanidins by high performance liquid chromatography combined with response surface methodology. Health Risk Analysis, 2019, no. 3, pp. 118-127. DOI: 10.21668/health.risk/2019.3.14.eng

Received: 27.05.2019

Accepted: 26.07.2019

Published: 30.09.2019 


\title{
TOXICOLOGICAL RESEARCH IN HEALTH RISK ASSESSMENT
}

UDC 616.127-005.8

DOI: $10.21668 /$ health.risk/2019.3.15.eng

\section{CARDIOTROPIC PROPERTIES OF CHROMONE-3-ALDEHYDE DERIVATIVES UNDER AN EXPERIMENTAL CARDIAC INFARCTION COMPLICATED WITH HYPERCHOLESTEROLEMIA}

\author{
A.V. Voronkov ${ }^{1}$, D.I. Pozdnyakov ${ }^{1}$, V.M. Rukovitsyna ${ }^{1}$, E.T. Oganesyan ${ }^{1}$, M.P. Voronkova ${ }^{2}$ \\ ${ }^{1}$ Pyatigorsk Medical Pharmaceutical Institute of Volgograd Medical State University of the Ministry of Health \\ Care of Russia, 11 Kalinin Ave., Pyatigorsk, 357532, Russian Federation \\ ${ }^{2}$ Volgograd State Medical University, 1 Pavshikh Bortsov Square, Volgograd, 400131, Russian Federation
}

\begin{abstract}
Cardiac infarction still remains a leading cause of mortality among population. There are a lot of risk factors causing the disease and complicating it; undoubtedly, they require correction. Our research goal was to experimentally assess cardiotropic peculiarities of 4 chromone-3-aldehyde derivatives (coded as $\mathrm{X} 3 \mathrm{AF}, \mathrm{X} 3 \mathrm{AFOK}, \mathrm{X} 3 \mathrm{ANO} \mathrm{O}_{2}$, and $\mathrm{X} 3 \mathrm{ANO} \mathrm{O}_{2} \mathrm{OK}$ ) as medications aimed at minimizing risks of acute cardiac infarction complicated with hypercholesterolemia. The experiment was performed on 70 male Wistar rats (pubescent, with body weight being equal to 220-240 grams); the animals were divided into 7 equal experimental groups, 10 animals in each. The first group was made up of falsely operated animals. We modeled atherogenesis in 60 remaining rats via oral introduction of $3 \%$ cholesterol dissolved in sunflower oil; the solution was introduced daily for 14 days. We also modeled acute cardiac infarction in them via ligating the left descending coronary artery with a silk thread. After 24 hours we performed electrocardiography to assess changes in QT range, and $P, R$, and T peaks amplitude. We also determined sizes of necrosis zones and ischemic damage foci in the cardiac muscle via double dying with Evans blue and tetrazolium chloride. We detected that compounds encoded as $\mathrm{X}_{3} \mathrm{ANO}_{2}, \mathrm{X}_{3} \mathrm{ANO}_{2} \mathrm{OK}, \mathrm{X} 3 \mathrm{AF}$ and $\mathrm{X} 3 \mathrm{AFOK}$ had hypocholesteremic and cardiotropic effects which led to electrophysiological properties returning to physiological standards and a decrease in ischemia/necrosis zones in the cardiac muscle under cardiac infarction. Objects encoded as $\mathrm{X}_{3} \mathrm{ANO}_{2} \mathrm{OK}$ and $\mathrm{X} 3 \mathrm{AFOK}$ were more pharmacologically active than $\mathrm{X}_{3} \mathrm{ANO}_{2}$ and $\mathrm{X} 3 \mathrm{AF}$, and $\mathrm{X}_{3} \mathrm{ANO}_{2} \mathrm{OK}$ substance was comparable to a reference medication, Meldonium in our case, in terms of its activity. Overall, the examined substances can be considered medications able to minimize risks of acute cardiac infarction complicated with hypercholesterolemia.

Key words: hypercholesterolemia, cardiac infarction, population mortality, risk factors, ischemia, necrosis, chromone derivatives, Meldonium, cardiac hystiocytes.
\end{abstract}

Despite all the successes that have been achieved in contemporary cardiology, mortality caused by cardiac infarction and its complications tends to grow. According to the WHO forecasts, by 2025 death cases caused by cardiac infarction are expected to rise from 17 million to 25 million annually $[1,2]$. It's common knowledge, that cardiac infarction means death of cardiac muscle cells (cardiac myocytes) that results from insufficient oxygen supply to the cardiac muscle, or cardiac muscle ischemia [3], and cardiac muscle cells start to die more than 6 hours after ischemia occurs [4]. Cardiac infarction develops due to

(C) Voronkov A.V., Pozdnyakov D.I., Rukovitsyna V.M., Oganesyan E.T., Voronkova M.P., 2019

Andrei V. Voronkov - Professor, Doctor of Medical Sciences, Head of Pharmacology Department with a course in clinical pharmacology (e-mail: prohor.77@mail.ru; +7 (962) 427-35-55; ORCID: https://orcid.org/0000-0001-6638-6223).

Dmitrii I. Pozdnyakov - PhD, senior lecturer, Pharmacology Department with a course in clinical pharmacology (e-mail: pozdniackow.dmitry@yandex.ru; +7 (918) 756-08-89; ORCID: https://orcid.org/0000-0003-0889-7855).

Victoria M. Rukovitsyna - post-graduate student, Organic Chemistry Department (e-mail: rukovitcina.vika@mail.ru; +7 (918) 750-85-45; ORCID: https://orcid.org/0000-0003-4104-9217).

Eduard T. Oganesyan - Professor, Doctor of Pharmaceutical Sciences Head of Organic Chemistry Department (e-mail: edwardow@mail.ru;+7 (928) 911-43-65; ORCID: https://orcid.org/0000-0002-2756-9382).

Maria P. Voronkova - Associate Professor, Doctor of Medical Sciences, Department for Pharmacology and Bioinformatics (e-mail: mpvoronkova@mail.ru; +7 (8442) 942-423; ORCID: https://orcid.org/0000-0001-6888-3725). 
several factors, primary ones being hyperlipidemia and atherosclerosis, hyperglycemia, smoking, arterial hypertension, alcoholism [5]. Besides, such factors as endothelial dysfunction, inflammation in vascular walls, cytokine cascade, and apoptosis [6] also make a significant contribution into cardiac infarction occurrence as they initiate damages in the cardiac muscle.

All the existing therapeutic strategies aimed at treating cardiac infarction are combinations of pharmaceutical, therapeutic, and instrumental techniques and "stent-technologies" [7] that are usually quite efficient. Their application allows to decrease mortality caused by acute cardiac infarction phase [8]. However, complications (mechanic, arrhythmic, ischemic, and inflammatory ones) that usually accompany cardiac infarction on the contrary make mortality among patients increase and it causes substantial health risks for population [9]. Given all the above stated, cardiac infarction prevention and risk factors elimination can be considered one of the most important tasks in contemporary medicine. Cardioprotectors are a pharmacological-therapeutic group of medications that exert favorable impacts on cardiac muscle functions and are predominantly aimed at prevention. Such medications can have direct and indirect effects [10]. Cardioprotectors with direct effects, or myocardial cytoprotectors, are the most promising; their action mechanism is directly aimed at recovering functions and stabilizing cell membranes, including mitochondria and lysosomes membranes [11]. This effect is pleiotropic when it comes to indirect cardioprotectors. At present, there are more than 2,000 molecules that can potentially have cardioprotecting properties, but much fewer compounds have been actually introduced into clinical practices and it calls for targeted searching for cardiotropic medications with multi-target action mechanism aimed at stabilizing cardiac muscle functioning and risk factors elimination [12].

Our research goal was to experimentally assess cardiotropic properties of chromone-3aldehyde derivatives as medications that could minimize risks of acute cardiac infarction complicated with hypercholesterolemia.

Data and methods. We performed our experimental research on 70 male Wistar rats (pubescent, with body weight being equal to 220-240 grams); the animals were divided into 7 experimental groups, 10 rats in each. The first group was falsely operated animals (FOA). We modeled atherogenesis in 60 remaining rats via oral introduction of 3-5 cholesterol solution in sunflower oil (Pancreac, Spain); the solution was introduced daily during 14 days [13]. The second group of rats was negative control (NC) as animals from this group didn't receive any pharmaceutical support. Animals from the third group were given a reference medication, Meldonium (Mildronate, Grindex (Latvia)) in a dose equal to 90 $\mathrm{mg} / \mathrm{kg}$ [14]. The 4th, 5th, 6th, and the 7th group of rats were given new chromone-3aldehyde derivatives encoded as $\mathrm{X} 3 \mathrm{AF}$, $\mathrm{X} 3 \mathrm{AFOK}, \mathrm{X} 3 \mathrm{ANO}_{2}$ и $\mathrm{X} 3 \mathrm{ANO}_{2} \mathrm{OK}$ respectively in a dose equal to $20 \mathrm{mg} / \mathrm{kg}$. All the examined medications and the reference one were daily introduced peros during 14 days, along with cholesterol introduction (there was a 2-hour break between two introductions), animals from NC group were given $0.9 \%$ sodium chloride solution in the same dose. When 14 days passed, we modeled acute cardiac infarction (ACI) in all the rats (including falsely operated animals who had undergone all the above-mentioned procedures, apart from coronary artery ligation) via ligating the left descending coronary artery with silk thread under chloral hydrate $(350 \mathrm{mg} / \mathrm{kg})$ anesthesia [14].

We performed electrocardiography 24 hours after ligation to monitor the experimental animals in the II standard lead with «Poly-Spectr8/B» electrocardiograph (Nuerosoft, Russia) with assessing changes in QT range, $\mathrm{P}, \mathrm{R}$, and $T$ waves. We also determined sized of necrosis zones and an ischemic damages focus in the cardiac muscle; to do that, we applied double dying with Evans blue and tetrazolium chloride (Figure 1) [15].

In order to examine probable favorable impacts exerted by the examined substances on lipid and lipoprotein blood profile, we assessed 


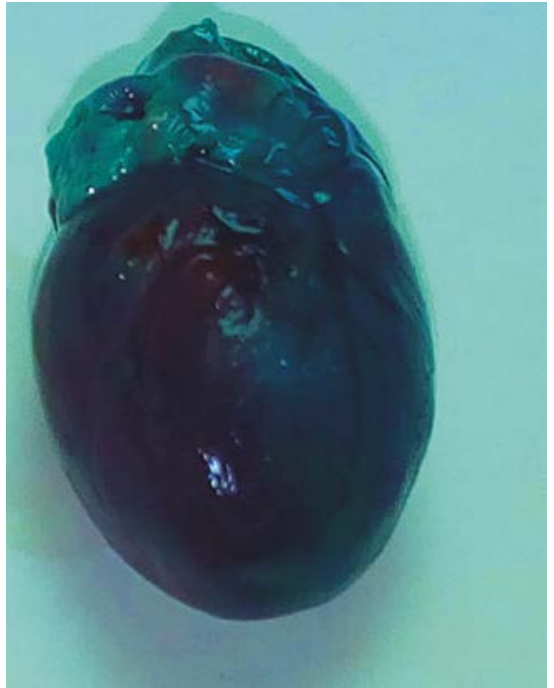

Figure 1. Double dying of the cardiac muscle with Evans blue and tetrazolium chloride obtained in the research

(after ACI had been modeled) changes in concentrations of total cholesterol (TC), lowdensity lipoproteins (LDLP cholesterol, LDLPC), high-density lipoproteins (HDLP cholesterol, HDLPC), and triglycerides (TG) in blood serum of the experimental animals (to do that, we applied standards reagent kits «Olveks Diagnosticum»). Samples preparation and analysis procedures conformed to the instructions given by a manufacturer of each reagent kit.

Experimental results were statistically processed with STATISTICA 6.0 package (StatSoft, the USA). Statistically significant discrepancies between groups of mean values were determined with "AVONA» technique together with Newman-Keuls post-test with significance level being $\mathrm{p}<0.05$.

Results and discussion. We assessed lipid and lipoprotein blood structure and detected that 14-day introduction of 3\% cholesterol solution in sunflower oil led to an increase in concentrations of total cholesterol, LDLP cholesterol, and TG (Table 1) in rats from the negative control group against falsely operated animals as these concentrations were by $54.3 \%$ $(\mathrm{p}<0.05), 86.2 \%(\mathrm{p}<0.05)$, and $35.1 \%(\mathrm{p}<0.05)$ higher in them respectively; as for HDLP cholesterol, it was by $43.8 \%$ lower in NC animals, than in falsely operated ones $(p<0.05)$.

Application of Meldonium under experimentally induced atherogenesis promoted lipid metabolism recovery (table 1) as it became apparent via a decrease in concentrations of TC, LDLPC, and TG in blood plasma of rats that were given Meldonium against animals from the negative control group; these concentrations were by $46.2 \%(p<0.05), 48.6 \%(p<0.05)$, and $28.3 \%(\mathrm{p}<0.05)$ lower respectively in the former group than in the latter one; HDLPC was also by $35.9 \%$ higher among rats which were given Meldonium than among animals from the negative control group $(\mathrm{p}<0.05)$.

We assessed impacts exerted by the examined substances on lipid-lipoprotein blood profile and analyzed the results; the analysis

Table 1

Influence exerted by the examined substances and the reference medication on changes in lipid and lipoprotein blood profile under experimentally induced hypercholesterolemia

\begin{tabular}{|l|c|c|c|c|}
\hline \multicolumn{1}{|c|}{ Group } & $\begin{array}{c}\text { Total cholesterol, } \\
\mathrm{mmol} / 1\end{array}$ & $\begin{array}{c}\text { LDLP cholesterol, } \\
\mathrm{mmol} / 1\end{array}$ & $\begin{array}{c}\text { HDLP cholesterol, } \\
\mathrm{mmol} / 1\end{array}$ & $\begin{array}{c}\text { Triglycerides, } \\
\mathrm{mmol} / 1\end{array}$ \\
\hline FOA & $2,34 \pm 0,1$ & $1,38 \pm 0,067$ & $0,92 \pm 0,033$ & $0,57 \pm 0,016$ \\
\hline $\mathrm{NC}$ & $3,61 \pm 0,126 \#$ & $2,57 \pm 0,177 \#$ & $0,64 \pm 0,029 \#$ & $0,77 \pm 0,014 \#$ \\
\hline Meldonium & $2,47 \pm 0,126^{*}$ & $1,73 \pm 0,082^{*}$ & $0,87 \pm 0,018^{*}$ & $0,60 \pm 0,027^{*}$ \\
\hline${\mathrm{X} 3 \mathrm{ANO}_{2}}_{\mathrm{X} 3 \mathrm{ANO} \mathrm{F}_{2} \mathrm{OK}}$ & $2,89 \pm 0,03^{*}$ & $2,11 \pm 0,054^{*}$ & $0,73 \pm 0,025^{*}$ & $0,64 \pm 0,013^{*}$ \\
\hline $\mathrm{X} 3 \mathrm{AF}$ & $2,37 \pm 0,054^{*}$ & $1,81 \pm 0,026^{*}$ & $0,79 \pm 0,022^{*}$ & $0,61 \pm 0,006^{*}$ \\
\hline $\mathrm{X} 3 \mathrm{AFOK}$ & $2,51 \pm 0,032^{*}$ & $2,35 \pm 0,047$ & $0,77 \pm 0,025^{*}$ & $0,64 \pm 0,011^{*}$ \\
\hline
\end{tabular}

Note: \# means a value is statistically significant against falsely operated animals $(\mathrm{p}<0.05) ;{ }^{*}$ means a value is statistically significant against the negative control group $(\mathrm{p}<0.05)$. 
revealed that $\mathrm{X} 3 \mathrm{ANO}_{2}$ and $\mathrm{X} 3 \mathrm{AFOK}$ led to practically the same changes in all the examined parameters (Table 1). Thus, $\mathrm{X} 3 \mathrm{ANO}_{2}$ and X3AFOK application led to $24.9 \% \quad(p<0.05)$ and $20.3 \%(p<0.05)$ decrease respectively in $\mathrm{TC}$ concentration (against the $\mathrm{NC}$ group); LDLPC was also lower (by 21.8\% $(\mathrm{p}<0.05)$ and $23.6 \%(\mathrm{p}<0.05)$ respectively); TG concentration was by $20.3 \%(\mathrm{p}<0.05)$ and $15 \%$ lower respectively. On the contrary, HDLPC concentration was higher after $\mathrm{X}_{3} \mathrm{ANO}_{2}$ and $\mathrm{X} 3 \mathrm{AFOK}$ introduction than in animals from the negative control group, by $14 \%(\mathrm{p}<0.05)$ and $12.5 \%(\mathrm{p}<0.05)$ respectively.

$\mathrm{X} 3 \mathrm{AF}$ introduction led to lower $\mathrm{TC}$ and TG concentrations in rats' blood plasma against the NC group, by $43.8 \%(p<0.05)$ and $20.3 \%$ $(\mathrm{p}<0.05)$ respectively. On the contrary, HDLPH concentration was by $20.4 \%$ higher after the substance was introduced (against the $\mathrm{NC}$ group) $(\mathrm{p}<0.05)$. After $\mathrm{X} 3 \mathrm{ANO}_{2} \mathrm{OK}$ was introduced, we detected lower concentrations of TC, LDLPC, and TG, as well as higher HDLPC concentration in rats' blood plasma, by $52.3 \%$ $(p<0.05), 42 \%(p<0.05), 26.2 \%(p<0.05)$, and $23.4 \%(\mathrm{p}<0.05)$ respectively.

We assessed changes in bioelectric parameters of heart functioning (Table 2) when acute cardiac infarction occurred and detected that $\mathrm{P}$ and $\mathrm{T}$ waves amplitudes were $3(\mathrm{p}<0.05)$ and $6(\mathrm{p}<0.05)$ times greater respectively in animals from the negative control group against falsely operated ones, and QT interval was by
$87.8 \%$ longer in them. Besides, $\mathrm{R}$ wave amplitude was 3.3 times $(\mathrm{p}<0.05)$ smaller in rats from the negative control group against falsely operated animals and these data are consistent with literature [16]. Preventive introduction of Meldonium resulted in favorable dynamics of changes in cardiac muscle electrophysiology in rats under cardiac infarction as $\mathrm{P}$ wave amplitude and QT interval length were 2 times $(p<0.05)$ and by $68.7 \%(p<0.05)$ lower respectively against animals from the negative control group, and $\mathrm{R}$ wave amplitude was 3.2 times greater $(p<0.05)$.

Introduction of the examined substances $\mathrm{X} 3 \mathrm{ANO}_{2}, \mathrm{X} 3 \mathrm{ANO}_{2} \mathrm{OK}, \mathrm{X} 3 \mathrm{AF}$, and X3AFOK led to an increase in $\mathrm{R}$ wave amplitude against animals from the negative control group, by $83.3 \%(\mathrm{p}<0.05) ; 166.7 \% \quad(\mathrm{p}<0.05) ; 133.3 \%$, and $216.7 \%(p<0.05)$ respectively. Besides, when $\mathrm{X}_{3} \mathrm{ANO}_{2}, \mathrm{X} 3 \mathrm{ANO}_{2} \mathrm{OK}$, and $\mathrm{X} 3 \mathrm{AFOK}$ were introduced, it resulted in a decrease in QT interval against the NC group by $38.5 \%$ $(p<0.05) ; 127.9 \%(p<0.05)$, and $51.6 \%(p<0.05)$ respectively. $\mathrm{T}$ wave amplitude went down by $33.3 \%(p<0.05)$ against the NC group after $\mathrm{X} 3 \mathrm{ANO}_{2} \mathrm{OK}$ introduction.

We analyzed data obtained in assessing changes in sizes of ischemia/necrosis zones in the cardiac muscle and revealed that Meldonium introduction led to a decrease in sizes of both ischemia and necrosis foci against the NC group, by $59.9 \%(\mathrm{p}<0.05)$ and $52.7 \%$ $(p<0.05)$ respectively (Figure 2$)$

Table 2

Influence exerted by the examined substances and the reference medication on changes in bioelectric parameters of heart functioning under acute cardiac infarction combined with experimentally induced hypercholesterolemia

\begin{tabular}{|l|c|c|c|c|}
\hline \multicolumn{1}{|c|}{ Group } & P, millivolt & R, millivolt & T, millivolt & QT, ms \\
\hline FOA & $0,02 \pm 0,004$ & $0,2 \pm 0,027$ & $0,04 \pm 0,01$ & $81,11 \pm 6,127$ \\
\hline NC & $0,06 \pm 0,004 \#$ & $0,06 \pm 0,017 \#$ & $0,24 \pm 0,027 \#$ & $152,36 \pm 3,269 \#$ \\
\hline Meldonium & $0,03 \pm 0,005$ & $0,19 \pm 0,013^{*}$ & $0,2 \pm 0,007$ & $90,33 \pm 4,235^{*}$ \\
\hline $\mathrm{X} \mathrm{ANO}_{2}$ & $0,04 \pm 0,002$ & $0,11 \pm 0,011^{*}$ & $0,2 \pm 0,015$ & $110,04 \pm 9,783^{*}$ \\
\hline $\mathrm{X} \mathrm{ANO}_{2} \mathrm{OK}$ & $0,04 \pm 0,004$ & $0,16 \pm 0,01^{*}$ & $0,18 \pm 0,009^{*}$ & $66,85 \pm 2,459^{*}$ \\
\hline $\mathrm{X} 3 \mathrm{AF}$ & $0,02 \pm 0,002$ & $0,14 \pm 0,005^{*}$ & $0,21 \pm 0,009$ & $139,12 \pm 3,297$ \\
\hline $\mathrm{X} 3 \mathrm{AFOK}$ & $0,03 \pm 0,004$ & $0,19 \pm 0,013^{*}$ & $0,23 \pm 0,022$ & $100,5 \pm 1,269^{*}$ \\
\hline
\end{tabular}

Note: \# means a value is statistically significant against falsely operated animals $(\mathrm{p}<0.05) ;{ }^{*}$ means a value is statistically significant against the negative control group $(\mathrm{p}<0.05)$. 


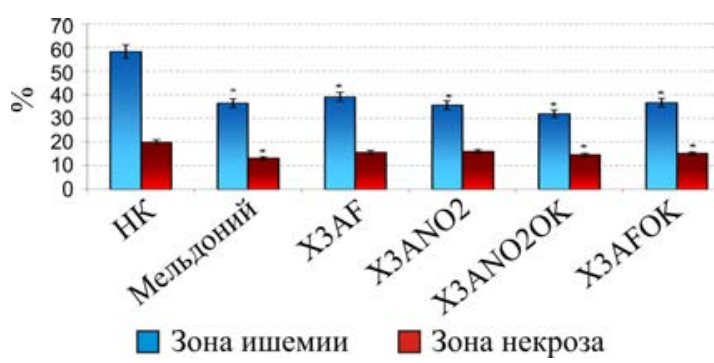

Figure 2. Changes in sizes of ischemia/necrosis zones in the cardiac muscle when correcting cardiac infarction complicated hypercholesterolemia with the examined substances and Meldonium

Note: \# means a value is statistically significant against falsely operated animals $(\mathrm{p}<0.05) ; *$ means a value is statistically significant against animals from the $\mathrm{NC}$ group $(\mathrm{p}<0.05)$.

After the examined substances X3ANO2, $\mathrm{X} 3 \mathrm{ANO} 2 \mathrm{OK}, \mathrm{X} 3 \mathrm{AF}$, and $\mathrm{X} 3 \mathrm{AFOK}$ were applied, sizes of ischemic damage zone in the cardiac muscle decreased against the $\mathrm{NC}$ group, by $63.7 \%(\mathrm{p}<0.05) ; 82 \%(\mathrm{p}<0.05) ; 48.8 \%(\mathrm{p}<0.05)$, and $59.1 \%(\mathrm{p}<0.05)$ respectively.

A necrotic focus decreased in sizes statistically significantly against animals from the $\mathrm{NC}$ group after X3ANO2OK and X3AFOK had been introduced, by $37.7 \%(\mathrm{p}<0.05)$ and $32.3 \%(\mathrm{p}<0.05)$ respectively.

Such cardiotropic effects produced by chromone-3-aldehyde derivatives can be due to their anti-cytokine properties. Chromone derivatives are known to be able to suppress occurrence of tumor necrosis factor- $\alpha$ (TNF- $\alpha)$ [17]. TNF- $\alpha$ activates external apoptosis path, and, in case of cardiac infarction, it promotes greater necrotic foci and, as a result, systolic functions performed by the left ventricle dete- riorate substantially [18]. Besides, greater TNF$\alpha$ concentration leads to inflammation cascade development and fibrosis in the cardiac muscle thus exerting adverse impacts on the disease course [19]. Favorable effects produced by the examined chromone derivatives on lipid metabolism can be related to their regulatory capabilities as regards sirtuin proteins [20] that play an important role in metabolic reactions of lipoproteins, fat acids, and dextrose [21].

Conclusion. Our research revealed that new chromone-3-aldehyde derivatives had cholesterol-lowering and cardiotropic effects. Cholesterol-lowering effects produced by the examined substances became apparent as lipidlipoprotein blood profile returned to its physiological standards while their cardiotropic effects assessed under modeled cardiac infarction complicated with hypercholesterolemia promoted recovery of electrophysiological properties and decrease in sizes of ischemia/necrosis zones in the cardiac muscle. All the obtained data allowed us to assume that $\mathrm{X} 3 \mathrm{ANO}_{2} \mathrm{OK}$ and $\mathrm{X} 3 \mathrm{AFOK}$ substances were more pharmacologically active than $\mathrm{X} 3 \mathrm{ANO}_{2}$ and $\mathrm{X} 3 \mathrm{AF}$. The research object encoded as $\mathrm{X} 3 \mathrm{ANO}_{2} \mathrm{OK}$ has pharmacological properties comparable to those of Meldonium, which was the reference medication in the research. Overall, these substances can be considered medications aimed at minimizing risks of acute cardiac infarction complicated with hypercholesterolemia.

Funding. The research was not granted any sponsor support.

Conflict of interests. The authors state there is no any conflict of interests.

\section{References}

1. Zhernakova N.I., Romashchenko O.V., Gorbach T.V., Zvereva V.A., Konstantinov S.L. [et al]. Kliniko-eksperimental'noe issledovanie effektivnosti fosfokreatina pri ishemii miokarda [Clinical and experimental study of the effectiveness of phosphocreatine in myocardial ischemia]. Nauchnye vedomosti BelGU. Seriya: Meditsina. Farmatsiya, 2012, vol. 135, no. 16, pp. 176-181 (in Russian).

2. Kuz'michev D.E., Vil'tsev I.M., Skrebov R.V., Chirkov S.V. Infarkt miokarda v klinike [Myocardial infarction in the clinic]. Problemy ekspertizy $v$ meditsine, 2015, vol. 57-58, no. 1-2, pp. 49-51 (in Russian). 
3. Shpektor A.V., Vasil'eva E.Yu. New definitions of myocardial infarctions (comments on "Universal definitions of myocardial infarction" published in № 5, 2008). Ratsional'naya farmakoterapiya $v$ kardiologii, 2009, vol. 5, no. 1, pp. 112-113 (in Russian).

4. Mythili S., Malathi N. Diagnostic markers of acute myocardial infarction. Biomedical Reports, 2015, vol. 6, no. 3, pp. 743-748. DOI: 10.3892/br.2015.500

5. Ilic M., Grujicic Sipetic S., Ristic B. Myocardial infarction and alcohol consumption: A casecontrol study. PLOS ONE, 2018, vol. 13, no. 6, p. e0198129. DOI: 10.1371/journal.pone.0198129

6. Libby P., Ridker P.M., Maseri A. Inflammation and atherosclerosis. Circulation, 2002, no. 105, pp. 1135-1143. DOI: $10.1161 / \mathrm{hc} 0902.104353$

7. Cunningham K.S., Gotlieb A.I. The role of shear stress in the pathogenesis of atherosclerosis. Lab. Invest., 2005, no. 85, pp. 9-23. DOI: 10.1038/labinvest.3700299

8. Reddy K., Khaliq A., Henning R.J. Recent advances in the diagnosis and treatment of acute myocardial infarction. World Journal of Cardiology, 2015, vol. 7, no. 5, pp. 243-276. DOI: 10.4330/wjc.v7.i5.243

9. Herrett E., Shah A.D., Boggon R., Denaxas S., Smeeth L., Van Staa T., Timmis A., Hemingway $\mathrm{H}$. Completeness and diagnostic validity of recording acute myocardial infarction events in primary care, hospital care, disease registry, and national mortality records: cohort study. The BMJ, 2013, vol. 346, pp.f2350. DOI: 10.1136/bmj.f2350

10. Mullasari A.S., Balaji P., Khando T. Managing complications in acute myocardial infarction. J. Assoc. Physicians India, 2011, vol. 59, pp. 43-48.

11. Sadovnikova I.I. Kardioprotektory. Nedootsenennye vozmozhnosti [Cardioprotectors. Underrated opportunities]. Russkii meditsinskii zhurnal, 2009, vol. 17, no. 18, pp. 1132-1134 (in Russian).

12. Bezuglaya V. Pharmaceuticals possessing both ergogenic and cardioprotective properties in the practice of athletes" training. Nauka v olimpiiskom sporte, 2016, no. 4, pp. 59-64 (in Russian).

13. Gunina L.M., Bezuglaya V.V. Cardioprotectors in sports medicine: problems and search for solutions. Sovremennye zdorov'esberegayushchie tekhnologii, 2016, no. 4, pp. 91-101 (in Russian).

14. Yuzhik E.I., Lushnikova E.L. Medical-biological problems of atherosclerosis modeling. Fundamental'nye issledovaniya, 2012, no. 10-1, pp. 176-183 (in Russian).

15. Danilenko L.M., Pokrovskii M.V., Kharitonova O.V., Klochkova G.N., Skachilova S.Ya., Kesarev O.G., Belyaev K.A., Khavanskii A.V. Izuchenie protivoishemicheskoi aktivnosti v ryadu proizvodnykh 3-(2, 2, 2-trimetilgidrazinii) propionata pri modelirovanii koronarookklyuzionnogo infarkta miokarda [The study of the antiischemic activity in a number derivatives of 3-(2, 2, 2-trimethylhydrazine) propionate in the simulation koronarolitikov myocardial infarction]. Nauchnye vedomosti BelGU. Seriya: Meditsina. Farmatsiya, 2011, vol. 117, no. 22-2, pp. 5-8 (in Russian).

16. Xu Q., Li Q.-G., Fan G.-R., Liu Q.-H., Mi F.-L., Liu B. Protective effects of fentanyl preconditioning on cardiomyocyte apoptosis induced by ischemia-reperfusion in rats. Brazilian Journal of Medical and Biological Research, 2017, vol. 50, no. 2, e5286 p. DOI: 10.1590/1414$431 \times 20165286$

17. Sun X., Cai J., Fan X., Han P., Xie Y., Chen J., Xiao Y., Kang Y.J. Decreases in Electrocardiographic R-Wave Amplitude and QT Interval Predict Myocardial Ischemic Infarction in Rhesus Monkeys with Left Anterior Descending Artery Ligation. PLOS ONE, 2013, no. 8, pp. e71876. DOI: 10.1371/journal.pone.0071876

18. Nancy T., Subin M.Z. Pharmacological Activities Of Chromene Derivatives: An Overview. Asian Journal of Pharmaceutical And Clinical Research, 2013, vol. 6, pp. 11-15.

19. Jarr K.U., Eschricht S., Burkly L.C., Preusch M., Katus H.A., Frey N., E. Chorianopoulos. TNF-Like Weak Inducer of Apoptosis Aggravates Left Ventricular Dysfunction after Myocardial Infarction in Mice. Mediators of Inflammation, 2014, Article ID 131950. Available at: https://www.hindawi.com/journals/mi/2014/131950/ (23.04.2019)

20. Frangogiannis N.G. The inflammatory response in myocardial injury, repair and remodeling. Nature reviews Cardiology, 2014, vol. 11, no. 5, pp. 255-265. DOI: 10.1038/nrcardio.2014.28 
21. Fridén-Saxin M., Seifert T., Landergren M.R., Suuronen T., Lahtela-Kakkonen M., Jarho E.M., Luthman K. Synthesis and Evaluation of Substituted Chroman-4-one and Chromone Derivatives as Sirtuin 2-Selective Inhibitors. Journal of Medicinal Chemistry, 2012, vol. 16, no. 55, pp. 7104-7113. DOI: $10.1021 / \mathrm{jm} 3005288$

22. Yu J., Auwerx J. The role of sirtuins in the control of metabolic homeostasis. Annals of the New York Academy of Sciences, 2009, no. 1173, pp. E10-E19. DOI: 10.1111/j.17496632.2009.04952.x

Voronkov A.V., Pozdnyakov D.I., Rukovitsyna V.M., Oganesyan E.T., Voronkova M.P. Cardiotropic properties of chromone-3-aldehyde derivatives under an experimental cardiac infarction complicated with hypercholesterolemia. Health Risk Analysis, 2019, no. 3, pp. 128-134. DOI: 10.21668/ health.risk/2019.3.15.eng

Received: 19.04.2018

Accepted: 20.07.2019

Published: 30.09.2019 


\title{
HEALTH RISK ANALYSIS: SOCIAL, ECONOMIC FACTORS
}

UDC 613.956

DOI: $10.21668 /$ health.risk/2019.3.16.eng

\section{ASSESSING HEALTH RISKS FOR SCHOOLCHILDREN AND STUDENTS CAUSED BY EXPOSURE TO EDUCATIONAL AND ENTERTAINING INFORMATION TECHNOLOGIES}

\author{
O.Yu. Milushkina ${ }^{1}$, N.A. Skoblina ${ }^{1}$, S.V. Markelova ${ }^{1}$, \\ A.A. Tatarinchik ${ }^{1}$, N.A. Bokareva ${ }^{1}$, D.M. Fedotov ${ }^{2}$
}

${ }^{1}$ Pirogov Russian National Research Medical University, 1 Ostrovitianov Str., Moscow, 117997, Russian Federation

${ }^{2}$ Northern State Medical University, 51 Troitskiy Ave., Arkhangelsk, 163000, Russian Federation

Information and communication technologies play a significant role in life of children, teenagers and young people as they are massively spread among these age groups. It is a new risk factor that can cause health disorders among oncoming generation. Our research objects were 465 senior schoolchildren living in Moscow and Moscow region and 598 students from Moscow and Arkhangelsk. Our research goal was to study influences exerted by information and communication technologies on health of senior schoolchildren and students; to do that, we applied risk assessment procedures, including hygienic, sociological, instrumental, and statistic techniques, as well as risk assessment itself. The obtained results revealed a negative trend and it was a growing number of young people with overweight and obesity.

We determined how and to what extent various frequency of electronic devices being in use influenced deviations in physical development of senior schoolchildren and students $(p<0.05)$ : a correlation between body weight and frequency of using a PC (0.60); fat mass and frequency of using a PC (0.67); control over fat mass and frequency of using a PC (-0.62); control over body weight and frequency of using a PC (-0.54); a fat mass fraction and frequency of using a PC (0.58). We detected an average and a high risk of myopia (RR - 6.62), disorders and diseases in the neuropsychic sphere (RR - 5.60) depending on how frequently young people used a laptop or a PC with an etiologic component being high in these two factors (62.4\% and $21.9 \%$ accordingly). We also detected a cause-and-effect relationship between functional disorders and diseases of the musculoskeletal system (RR - 1.20-1.48) and using a PC, laptop or a pad with an attributive risk related to these factors being considerable (21.7\% for using a pad and $11.7 \%$ for using a PC or a laptop). We determined a safe period of time for "overall" use of electronic devices in educational activities and for entertaining; this period should not exceed 3 hours.

Key words: risks, schoolchildren, students, information and communication technologies, electronic devices, myopia, overweight, muscle strength.

A child's body is constantly growing and developing; should the process be disrupted due to either endogenous or exogenous factors, it is considered hazardous for a child's health $[1,2]$.
Over the last decades new hygienic factors have occurred and influence exerted by them on formation of a child's body hasn't been studied in great detail. Application of information and

(C) Milushkina O.Yu., Skoblina N.A., Markelova S.V., Tatarinchik A.A., Bokareva N.A., Fedotov D.M., 2019

Olga Yu. Milushkina - Doctor of Medical Sciences, Associate Professor, Head of the Hygiene Department, Pediatrics Faculty (e-mail: milushkina_o@rsmu.ru; tel.: +7 (916) 656-80-20; ORCID: https://orcid.org/0000-0001-6534-7951).

Natalia A. Skoblina - Doctor of Medical Sciences, Professor, Professor at the Hygiene Department, Pediatrics Faculty (e-mail: skoblina_dom@mail.ru; tel.: +7 (903) 247-71-82; ORCID: https://orcid.org/0000-0001-7348-9984).

Svetlana V. Markelova - Candidate of Medical Sciences, Associate Professor at the Hygiene Department, Pediatrics Faculty (e-mail: markelova.sve@yandex.ru; tel.: +7 (916) 526-23-48; ORCID: https://orcid.org/0000-0003-0584-2322).

Andrei A. Tatarinchik - post-graduate student at the Hygiene Department, Pediatrics Faculty (e-mail: this.charming.man@mail.ru; tel.:+7 (926) 100-58-84; ORCID: https://orcid.org/0000-0002-9254-2880).

Natalia A. Bokareva- Doctor of Medical Sciences, Associate Professor at the Hygiene Department, Pediatrics Faculty (e-mail: nabokareva@mail.ru; tel.: +7 (916) 351-72-21; ORCID: https://orcid.org/0000-0002-6685-1946).

Denis M. Fedotov - Candidate of Medical Sciences, Associate Professor, Deputy Dean of the Medical and Prevention and Medical Biochemistry Faculty (e-mail: doctorpro@yandex.ru; tel.: +7 (911) 870-76-93; ORCID: https://orcid.org/00000002-4067-8364). 
communication technologies (ICT) is one of such factors. At present schoolchildren and students widely use ICT as it is almost impossible to imagine contemporary educational processes and socialization without them in a hyperinformation society [3-7].

In 2015 the RF Government approved on the Concept of Information Security for Children; the document clarified how significant information technologies were for a child's development ${ }^{1}$.

As it is fixed in the Concept, information security for children means both protecting them from destabilizing impacts exerted by certain information products and creating favorable information environment that could support positive socialization and individualization, optimal social, personal, cognitive, and physical development and help preserving mental and psychological health and wellbeing as well as creating positive mentality.

But still, most contemporary research that dwells on examining impacts exerted by ICT on children's and teenagers' bodies focuses on effects produced on a human body by electromagnetic fields. Thus, intensity of electromagnetic radiation created by electronic appliances (EAs) was examined by Grigoryeva Yu.T et al (2017), Teksheva L.M. et al (2011), Vyatleva O.A., Kurganskiy A.M. (2018), Ushakvo I.B. et al (2018), HardellL. (2018) [8-12]. Peculiarities related to ICT use by children and teenagers and influence exerted by ICT on young people were analyzed and examined by Saprykina G.A. (2012), Medvedeva E.A. et al. (2014), Kuchma V.R. et al. (2016) [13-15]. A lot of research works focused on impacts exerted by ICT on participants in educational processes (Kuchma V.R. et al, 2015; Stepanova M.I. et al., 2015; BelandL.P., 2015) [16-18]. Scientific literature contains a lot of data on impacts exerted by ICT on psychological and psychophysiological parameters of a growing body and already grown one [19-23]. And there are only few works that focus on impacts exerted by ICT on development of a child's body [23]. Hygienic aspects related to children using ICT in leisure activities haven't been given sufficient attention; the situation is the same with hygienic standards fixed for such activities when ICT are used by children, teenagers, and young people.

All the above-mentioned issues are to be resolved within implementing the Federal project entitled "Public health improvement" in 2019 and in future, 2020-2024; this project is an integral part of the National project called "Demography" which is being implemented with Rospotrebnadzor participation (the Order by Rospotrebnadzor No. 29 issued on January $25,2019)^{2}$.

Our research goal was to apply risk calculation procedures and to examine essence and an extent to which information and communication technologies influenced health of senior schoolchildren and students.

Research objects. 465 senior schoolchildren from Moscow city and Moscow region and 568 students from Moscow and Arkhangelsk took part in our research. The examined senior schoolchildren were 16 years old; students, 20. Those age groups were selected as our research objects due to senior schoolchildren and students being able to plan their use of information and communication technologies on their own, without any limitations imposed by their parents.

We chose those educational establishments where administrative staff and parents (at schools) gave their consent to our research. Schools selected for our research included comprehensive ones, schools with ad-

\footnotetext{
${ }^{1}$ The Concept of Information Security for Children / approved by the RF Government Order No. 2471-r on December 2, 2015. Available at: cronao.ru/images/DAR/InformSafe/Koncepciya-iform-bez-detey.pdf (date of visit March 02, 2019).

${ }^{2}$ Demography: The National project profile / approved by the minutes of the RF Presidential Council on strategic development and national projects No. 16 dated December 24, 2018. Available at: https://rosmintrud.ru/ministry/programms/demography (date of visit March 02, 2019).
} 
vanced studies of some subjects, and grammar schools. There were two basic educational programs attended by students who took parts in our research, "Public Healthcare and Medical Sciences" and "Mathematics and Mechanics".

Our research didn't infringe on human rights and didn't cause any hazards for examined children; it conformed to all requirements fixed by biomedical ethics; it was planned and approved in accordance with GCP Rules by the Ethical Committee of N.I. Pirogov's Russian National Research Medical University. All examinations were performed according to ethical standards fixed by Helsinki Declaration and EU Directives $(8 / 609 \mathrm{EU})^{3}$.

We applied the following research techniques: hygienic, sociological, instrumental, and statistical ones, and risk assessment procedures.

Physical development of children, teenagers, and young people is the most significant criterion showing how healthy they are; taking this into account, we analyzed body mass index and assessed fat mass of a body via biological impedance analysis (InBody 230 analyzer, Korea), standard anthropometric measurements, and dynamometry.

Highly qualified ophthalmologists examined health of senior schoolchildren and students; we also applied ARMIS firmware (Rostov-on-Don, Russia) to accomplish diagnostics. Data obtained via preventive examinations were analyzed with medical experts rendering their assistance in the process.

To assess influence exerted on health of senior schoolchildren and students by their life style as well as frequency and duration of ICT use, we accomplished questioning with stan- dardized questionnaires developed by Scientific Research Institute for Hygiene and Children's Health Protection of the RF Public healthcare Ministry.

We examined educational conditions for children and teenagers at 12 educational establishments of different types; to do that, we performed sanitary-hygienic examination of educational establishments with subsequent analysis accomplished according to methodical procedures suggested by $\mathrm{O} . \mathrm{Yu} \mathrm{Mi}-$ lushkina ${ }^{4}$.

All the obtained data were statistically processed with Statistica 10.0 software package for statistical analysis (StatSoft, the USA).

Relative risk (RR or a probability of a certain outcome depending on an environmental factor) was determined as per evidence-based medicine rules using fourfold contingency tables.

Results. The obtained results allowed us to reveal a negative trend for an increase in number of senior schoolchildren and students who had overweight and obesity.

We analyzed how harmonious their physical development was and revealed that $60.6 \% \pm 1.2 \%$ of the examined male senior schoolchildren and $56.8 \% \pm 2.4 \%$ of the examined male students had normal (harmonious) physical development.

$12.2 \% \pm 2.1 \%$ of the examined male senior schoolchildren and $24.6 \% \pm 1.2 \%$ of the examined male students had overweight, and students tended to have it two times more frequently than schoolchildren. Obesity was detected in $3.0 \% \pm 0.9 \%$ and $8.3 \% \pm 1.1 \%$ respectively, and students tended to have it 2.8 times more frequently. We didn't detect any regional peculiarities related to these parameters.

\footnotetext{
${ }^{3}$ Helsinki Declaration by World Medical Association / approved by the 18th World Medical Assembly, Helsinki, Finland, June 1964; revised by the 29th World Medical Assembly, Tokyo, Japan, October 1975, the 35the World Medical Assembly, Venetia, Italy, October 1983, the 41th World Medical Assembly, Hong Cong, September 1989 and the 48the General Assembly, Somerset West, SAR, October 1996. Available at:: https://rostgmu.ru/wp-content/uploads/2014/ 12/WMA_Helsinki.pdf (date of visit March 02, 2019).

${ }^{4}$ Milushkina O.Yu. Regularities in formation of morphofunctional parameters in children and teenagers under contemporary medical-social and sanitary-hygienic conditions: doctoral thesis ... for a Doctor of Medical Sciences degree. Moscow, 2013, 313 p.
} 
As regards female participants, we revealed that $61.2 \% \pm 2.7 \%$ of the examined female senior schoolchildren and $63.3 \% \pm 1.5 \%$ of the examined female students had normal (harmonious) physical development.

$6.2 \% \pm 1.1 \%$ of the examined female schoolchildren and $12.0 \% \pm 1.5 \%$ of the examined female students had overweight and female students tended to have it two times more frequently. Obesity was detected in $2.0 \% \pm 0.4 \%$ and $3.0 \% \pm 0.4 \%$ respectively. We didn't detect any regional peculiarities related to these parameters.

Male senior schoolchildren tended to have average body mass index equal to $21.1 \pm$ $\pm 3.2 \mathrm{~kg} / \mathrm{m}^{2}$; and female senior schoolchildren, $20.1 \pm 3.3 \mathrm{~kg} / \mathrm{m}^{2}$ (standard for this age was equal to 18.5-24.9). Male students from Moscow and Arkhangelsk had average body mass index equal to $23.0 \pm 3.7 \mathrm{~kg} / \mathrm{m}^{2}$ and $23.4 \pm 4.5 \mathrm{~kg} / \mathrm{m}^{2}$. Female students from Moscow and Arkhangelsk had average body mass index equal to $21.3 \pm 3.5 \mathrm{~kg} / \mathrm{m}^{2}$ and $21.1 \pm 4.4 \mathrm{~kg} / \mathrm{m}^{2}$.

Male senior schoolchildren had their fat mass equal to $10.1 \pm 6.5 \mathrm{~kg}$; female senior schoolchildren, $13.0 \pm 5.7 \mathrm{~kg}$. Male students from Moscow had fat mass equal to $13.9 \pm 8.0 \mathrm{~kg}$; female students from Moscow, $15.9 \pm 7.6 \mathrm{~kg}$. Male students from Arkhangelsk had average fat mass equal to $14.8 \pm 9.5 \mathrm{~kg}$; female students from Arkhangelsk, $15.6 \pm 6.6 \mathrm{~kg}$.

We should note that there was an authentic $(\mathrm{p}<0.05)$ age-dependent increase in average fat mass regardless of a sex and height as it remained stable. Fat mass percentage also grew from $15.0 \pm 1.8 \%$ in boys to $19.0 \pm 2.0 \%$ in young males and recommended values for men should not exceed $15.3 \%$. Fat mass percentage in girls authentically $(\mathrm{p}<0.05)$ grew from $23.0 \pm 1.8 \%$ to $26.0 \pm 3.5 \%$ and recommended values for women should not exceed $23.0 \%$.

Control over fat mass (a quantity of fat mass in kilograms that should be lost or gained) indicates that male students on average have to lose 3 or more $\mathrm{kg}$ of fat mass; female students, 2 or more $\mathrm{kg}$.

An existing negative trend for an increase in number of young people who have over- weight or obesity requires searching for factors that cause this pathology.

Our research allowed us to reveal that multiple correlation coefficient for overweight was $\mathrm{R}=0.55, \mathrm{p}<0.05$ for senior students, the correlation being detected between overweight and educational conditions at educational establishments and factors related to life style. Standardized regression coefficients (Beta) indicate there is influence exerted by a set of factors including sanitary-epidemiologic wellbeing at an educational establishment (-0.57), an amount of time spent daily working at a PC (0.44), unfavorable microclimate in a family (frequency of conflicts) (0.33), having dinner 2 or less hours before going to bed (-0.25).

We detected averaged total time of ICT use with various electronic appliances; it amounted to 7 hours on a usual weekday both in studies and leisure activities for senior schoolchildren; 8.5 hours, for male students; 10 hours, for female students.

We also revealed that ICT use as an independent activity accounted for $15 \%$ of the overall available daily time for senior schoolchildren; $10.0 \%$, for students.

A lot of time spent by senior schoolchildren and students on ICT during a day means they spend less time on other activities such as sleep, meals, doing sports, outdoor activities etc. Thus, time spent on sleep decreased by $9 \%$ among senior schoolchildren and by 7\% among students; time spent on doing sports and outdoor activities decreased by $6.0 \%$ among senior schoolchildren and by $4.0 \%$ among students.

We examined essence and extent to which various frequency of EAs application influenced occurrence of deviations in physical development of senior schoolchildren and students; we revealed the following statistically significant correlations $(\mathrm{p}<0.05)$ :

- between body weight and frequency of PC use (0.60);

- between fat mass and frequency of PC use (0.67);

- between control over fat mass (a quantity of fat mass in kilograms that should be gained or lost) and frequency of PC use (-0.62); 
- between control over weight (a quantity of body weight in kilograms that should be gained or lost) and frequency of PC use (-0.54);

- between fat mass percentage frequency of PC use (0.58).

Obtained statistically significant correlations between deviations in physical development of young people due to overweight and duration of stationary EAs use confirmed it was necessary to control time spent uninterruptedly at such devices as frequent and long use of EAs could increase static loads on a growing body.

We can show consequent steps in this influence with the following scheme: more frequent and longer EAs use $\rightarrow$ greater static load / lower physical activity $\rightarrow$ an increase in fat mass $\rightarrow$ deviations in physical development caused by overweight.

This hypothesis can be tested with risks calculation. We determined statistically significant values of relative risks (RR) related to different frequency of stationary EAs use (a PC or a laptop) for overweight and obesity occurrence in senior schoolchildren and students (Table 1).

When relative risk is higher than 1 , and in our case it is equal to 1.59 , we can conclude that a factor (frequent use of a PC or a laptop) increases frequency of adverse outcomes, notably overweight and obesity (direct correlation) among young people. Etiologic fraction in this factor amounts to practically $10 \%$, however, there are undoubtedly other influencing factors.

Table 1

Relative risk of overweight and obesity in senior schoolchildren and students depending on frequency of stationary EAs use $(\mathrm{p} \leq 0.05)$

\begin{tabular}{|c|c|c|c|c|c|}
\hline Outcome & Factor & RR & EF, \% & Se & Sp \\
\hline $\begin{array}{c}\text { Overweight } \\
\text { and obesity }\end{array}$ & $\begin{array}{c}\text { Frequency } \\
\text { of PC or laptop } \\
\text { use }\end{array}$ & 1.59 & 9.8 & 0.67 & 0.47 \\
\hline
\end{tabular}

Note:

$\mathrm{RR}$ is relative risk;

EF etiologic fraction (attributive risk);

Se is sensitivity of a technique;

$\mathrm{Sp}$ is specificity of a technique.
We determined statistically significant relative risk values related to different frequency of a PC or laptop use for another important parameter that characterized physical development of children and teenagers. This parameter was muscle strength in hands; a decrease in this parameter often occurs together with overweight and obesity (Table 2).

When relative risk is higher than 1 , and in our case it is equal to 1.08 when a PC is used, and to 1.11, when a laptop is used, we can conclude that the factor increases frequency of such adverse outcomes as reduced muscle strength. Etiologic fraction in these factors amounts to $13.0 \%$ and $25.0 \%$ respectively; undoubtedly, there are other influencing risk factors.

\section{Table 2}

Relative risk of a decrease in muscle strength in hands in senior schoolchildren depending on frequency of stationary EAs use $(\mathrm{p} \leq 0.05)$

\begin{tabular}{|l|c|c|c|c|c|}
\hline \multicolumn{1}{|c|}{ Outcomes } & Factor & RR & EF, \% & Se & Sp \\
\hline $\begin{array}{l}\text { Reduced } \\
\text { muscle } \\
\text { strength }\end{array}$ & $\begin{array}{l}\text { Frequency } \\
\text { of a PC use }\end{array}$ & 1.08 & 13.0 & 0.33 & 0.69 \\
\hline $\begin{array}{l}\text { Reduced } \\
\text { muscle } \\
\text { strength }\end{array}$ & $\begin{array}{c}\text { Frequency } \\
\text { of a laptop } \\
\text { use }\end{array}$ & 1.11 & 25.0 & 0.67 & 0.73 \\
\hline
\end{tabular}

Our research results indicate it is vital to develop hygienic standards for total time spent on ICT during a day for senior schoolchildren and students; these standards should take into account both educational and leisure activities while existing standards fixed in regulatory documents predominantly cover only educational activities.

Taking into account significance of everyday EAs use, we set a task to determine how much time spent on them a day wouldn't cause overweight among senior schoolchildren and students (Figure 1).

Having analyzed the data, we concluded that total time equal to up to 3 hours a day spent on EAs use both in educational and leisure activities was a safe limit for deviations in physical development of young people. 


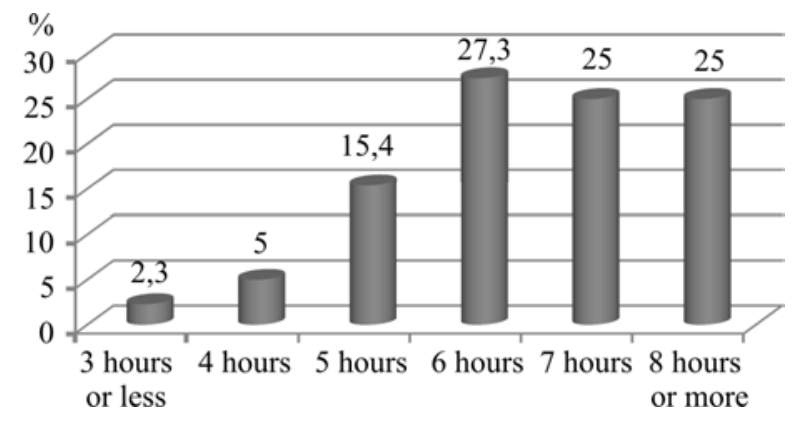

Figure 1. Frequency of deviations in physical development due to overweight in senior schoolchildren and students depending on time spent on EAs use a day, \%

We also obtained some data on influence exerted by frequency of EAs use on health disorders in senior schoolchildren and students (Table 3).

We confirmed a risk of average and grave myopia ( $R R-6.62$ ), and neuropsychic disorders and diseases (RR - 5.60) depending on frequency of a PC or laptop use with etiologic fraction of these factors being high $(62.4 \%$ and $21.9 \%$ respectively).

We detected a cause-and-effect relation between functional disorders and diseases in the musculoskeletal system ( RR - $1.20-1.48)$ and use of a PC, laptop, or a pad with etiologic fraction of these factor being significant (21.7\% when a pad was used and $11.7 \%$ when a PC or a laptop was used). We also revealed risks of functional disorders or diseases in the hearing organs depending on how frequently EA with headphones were used; the risks were 2.41 and etiological fraction was equal to $10.0 \%$.

Discussion. Contemporary electronic industry offers a wide range of EAs to consumers; these devices can satisfy any need a customer might have and it stimulates greater interest in them among children, teenagers, and young people [14].

Previously it was shown that more frequent and longer use of EAs changed life styles of contemporary schoolchildren and students, violating normal ratios of activities in their daily routines and influencing their health [24]; the situation seems alarming to hygienists and requires developing standards for ICT use by children, teenagers, and young people in their educational and leisure activities.

Our research allowed us to determine total permissible amount of time that can be spent on ICT during a day and it shouldn't exceed 3 hours; this amount wouldn't cause any adverse effects on young people's health that could result in overweight.

Our data are well in line with research results obtained via examining influence exerted by ICT on emotional and behavioral disorders among teenagers ${ }^{5}$.

Table 3

Relative risk of health disorders among senior schoolchildren and students depending on frequency of EAs use $(\mathrm{p} \leq 0.05)$

\begin{tabular}{|l|c|c|c|c|c|}
\hline \multicolumn{1}{|c|}{ Outcomes } & Factor & RR & EF, \% & Se & Sp \\
\hline $\begin{array}{l}\text { Average or grave myopia } \\
\text { Neuropsychic functional disorders } \\
\text { and diseases }\end{array}$ & PC or laptop, frequency of use & 6.62 & 62.4 & 0.96 & 0.47 \\
\hline $\begin{array}{l}\text { Functional disorders and diseases } \\
\text { in the musculoskeletal system }\end{array}$ & PC or laptop, frequency of use & 1.20 & 11.7 & 0.33 & 0.77 \\
\hline $\begin{array}{l}\text { Functional disorders and diseases } \\
\text { in the musculoskeletal system }\end{array}$ & Pad, frequency of use & 1.48 & 21.7 & 0.53 & 0.69 \\
\hline $\begin{array}{l}\text { Functional disorders and diseases } \\
\text { in the hearing organs }\end{array}$ & $\begin{array}{c}\text { Frequency of use of EAs } \\
\text { with headphones }\end{array}$ & 2.41 & 9.5 & 0.72 & 0.51 \\
\hline
\end{tabular}

\footnotetext{
${ }^{5}$ Labutieva I.S. Hygienic assessment of influence exerted by contemporary life activities of studying teenagers on occurrence of emotional and behavioral disorders: thesis ... for a Candidate of Medical Sciences degree. Moscow, 2018, 23 p.
} 
Our research proved there was a causeand-effect relation between health disorders among young people (average or grave myopia, neuropsychic disorders or diseases, functional disorders or diseases in the musculoskeletal system and hearing organs) and frequency of different EA use. The results we obtained determine a necessity to introduce a differentiated approach to standardizing safe levels of exposure to adverse factors related to ICT use; this approach should take into account a type of used EA, age and health of a user, regime and conditions under which an EA is used etc.

Use of ICT is widely spread among young people at present; use of EA is proven to cause risks of adverse effects on a goring body; people tend not to be aware of how safely to use EA; there is no successive system of hygienic education. Taking all the above-mentioned factors into account, we should state is it obviously necessary to perform further research in the sphere in order to develop a set of preventive activities [25, 26]. A significant trend in prevention should be strengthening and enhancing primary prevention of diseases which are typical for a hyperinformation society via creating and maintaining efficient methodical and technical information resources on developing and applying skills related to safe EAs use. Here we should also take into account basic ways used by contemporary young people to obtain information as well as how this information is introduced and implemented into everyday life. Subject web-sites and blogs on healthy life style, including those for active EAs users, may be quite useful in this respect. This research should become an integral part of scientific work planned within "The Program for multi-centered research on providing digital educational technologies that are safe for children's health".

Conclusion. Given all the above-mentioned, we can state that at present it is necessary to search for the most efficient ways to create healthy life-style attitudes among children, teenagers, and young people. Today any issues related to preserving young people's health should be solved by experts from various fields of knowledge (hygienists, ophthalmologists, pediatricians, teachers, psychologists, etc). Creation of unified prevention space requires combining efforts made by all participants in prevention processes and a whole society as well.

Funding. The research was not granted any financial support.

Conflict of interests. The authors declare there is no any conflict of interest.

\section{References}

1. Kuchma V.R., Milushkina O.Yu., Skoblina N.A. Morfofunktsional'noe razvitie sovremennykh shkol'nikov [Morphofunctional development of contemporary schoolchildren]. Moscow, Geotar-Media Publ, 2018 (in Russian).

2. Kuchma V.R., Skoblina N.A., Platonova A.G. Physical development in Moscow and Kiev schoolchildren. Gigiena i sanitariya, 2011, no. 1, pp. 75-78 (in Russian).

3. Platonova A.G., Yatskovskaya N.Ya., Dzhurinskaya S.N., ShkarbanE.S. Impact of modern computer equipment on the functional state of visual analyzer in schoolchildren aged 13-14 years. Zdorov'e i okruzhayushchaya sreda, 2013, no. 23, pp. 144-148 (in Russian).

4. Vyatleva O.A., Teksheva L.M., Kurgansky A.M.Physiological and hygienic assessment of the impact of mobile phones with various radiation intensity on the functional state of brain of children and adolescents according to electroencephalographic data. Gigiena i sanitariya, 2016, vol. 95, no. 10, pp. 965-968 (in Russian).

5. Bukhtiyarov I.V., Denisov E.I., Eryomin A.L. Bases of information hygiene: concepts and problems of innovations. Gigiena i sanitariya, 2014, vol. 93, no. 4, pp. 5-9 (in Russian).

6. Denisov E.I. Robots, artificial intelligence, augmented and virtual reality: ethical, legal and hygienic issues. Gigiena i sanitariya, 2019, vol. 98, no. 1, pp. 5-10 (in Russian).

7. Kuchma V.R., Sukhareva L.M., Rapoport I.K., Shubochkina E.I., Skoblina N.A., Milushkina O.Yu. Population health of children, risks to health and sanitary and epidemiological wellbeing of stu- 
dents: problems, ways of solution and technology of the activity. Gigiena i sanitariya, 2017, vol. 96, no. 10, pp. 990-995 (in Russian).

8. Grigor'ev Yu.G., Samoilov A.S., Bushmanov A.Yu., Khorseva N.I. Cellular Connection and the Health of Children - Problem of the Third Millennium. Meditsinskaya radiologiya i radiatsionnaya bezopasnost', 2017, vol. 62, no. 2, pp. 39-46 (in Russian).

9. Teksheva L.M., Barsukova N.K., Chumicheva O.A. Gigienicheskaya otsenka vliyaniya elektromagnitnykh polei sotovoi svyazi na organism detei i podrostkov [Hygienic assessment of impacts exerted by electromagnetic fields of cellular communication on children and teenagers]. Shkola zdorov'ya, 2011, no. 2, pp. 32-37 (in Russian).

10. Vyatleva O.A., Kurgansky A.M. Feathures of using of mobile communication (intensity of radiation, temporary modes) and their influence on the health of modern younger schoolchildren. Zdorov'e naseleniya i sreda obitaniya, 2018, vol. 305, no. 8, pp. 51-54 (in Russian).

11. Ushakov I.B., Popov V.I., Popova O.A. Some aspects of the person ecological safety in the conditions of chronic electromagnetic fields impulses influence. Ekologiya cheloveka, 2018, no. 1, pp. 3-7 (in Russian).

12. Hardell L., Carlberg M., Hedendahl L.K. Radiofrequency radiation from nearby base stations gives high levels in an apartment in Stockholm, Sweden: A case report. Oncology letters, 2018, vol. 15 , no. 5 , pp.7871-7883.

13. Saprykina G.A. Information and communication technologies as a formation factor of the person. Filosofiya i obrazovanie, 2012, vol. 40, no. 1, pp. 267-273.

14. Medvedeva I.E., Kroshilin S.V. Rasprostranenie internet-tekhnologii v Rossiii «guglizatsiya» soznaniya molodezhi [Internet-technologies spread in Russia and "googlization" of young people's minds]. Natsional'nye interesy: prioritety i bezopasnost', 2014, no. 3, pp. 9-19 (in Russian).

15. Kuchma V.R., Tkachuk E.A., Tarmaeva I.Yu. Psychophysiological state of children in conditions of informatization of their life activity and intensification of education. Gigiena $i$ sanitariya, 2016, vol. 95, no. 12, pp. 1183-1188 (in Russian).

16. Kuchma V.R., Tkachuk E.A., Efimova N.V. Hygienic estimation of an intensification of educational activities of children in modern conditions. Voprosy shkol'noi i universitetskoi meditsiny i zdorov'ya, 2015, no. 1, pp. 4-11 (in Russian).

17. Stepanova M.I., Aleksandrova I.E., Sazanyuk Z.I. Hygienic regulation of the use of electronic educational resources in the modern school. Gigiena i sanitariya, 2015, vol. 94, no. 7, pp. 64-68 (in Russian).

18. Belland L.P., Murphy R. Ill Communication: Technology, Distraction \& Student Performance. London, Centre for Economic Performance London School of Economics and Political Publ., 2015, 46 p.

19. Matyash M.I., Natarova A.A., Popov V.I., Krivtsova I.O. Zavisimost' kontsentratsii vnimaniya cheloveka ot elektromagnitnogo izlucheniya mobil'nogo telefona [Dependence between an ability to concentrate attention and electromagnetic radiation created by a mobile phone]. Molodezhnyi innovacionnyi vestnik, 2017, vol. 6, no. 2, pp. 258(in Russian).

20. Guenaga M., Mentxaka I., Eguiluz A. Smartphones and teenagers, threat or opportunity. In Proceedings of 15th International Conference on Interactive Collaborative Learning (ICL), 2012, pp. 1-5.

21. Ariani A., Putu N.M., Aditya R. Effects of Playing with Gadget on Elementary School Children in Urban and Rural Environment. Advances in Health Sciences Research, 2017, vol. 2. pp. 22-27.

22. Papaconstantinou E., Bartfay W.J., Bartfay E. Smartphone use, sleep quality and quantity, and mental health outcomes in a university population. Sleep Medicine, 2017, vol. 40, pp. 251.

23. Woo E.H., White P., Lai C.W. Impact of information and communication technology on child health. J. Pediatric. Child. Health, 2016, vol. 52, no. 6, pp. 590-594.

24. Milushkina O.Yu., Markelova S.V., Skoblina N.A., Tatarinchik A.A., Fedotov D.M., Korolik V.V., Al-Sabunchi A.A. Osobennosti obraza zhizni sovremennoi studencheskoi molodezhi. Zdorov'e naseleniya i sreda obitaniya, 2018, vol. 308, no. 11, pp. 5-8 (in Russian). 
25. Kuchma V.R., Milushkina O.Yu., Bokareva N.A., Skoblina N.A. Modern trends of preventive work in educational institutions. Gigiena i sanitariya, 2014, vol. 93, no. 6, pp. 107-111 (in Russian).

26. Baranov A.A., Kuchma V.R., Anufrieva E.V., Sokolova S.B., Skoblina N.A., Virabova A.R., Makarova A.Y., Trofimenko E.V. [et al.]. Quality evaluation of healthcare services in schools. Vestnik Rossiiskoi akademii meditsinskikh nauk, 2017, no. 3, pp. 180-194 (in Russian).

Milushkina O.Yu., Skoblina N.A., Markelova S.V., Tatarinchik A.A., Bokareva N.A., Fedotov D.M. Assessing health risks for schoolchildren and students caused by exposure to educational and entertaining information technologies. Health Risk Analysis, 2019, no. 3, pp. 135-143. DOI: 10.21668/ health.risk/2019.3.16.eng

Received: 12.03.2019

Accepted: 26.07.2019

Published: 30.09.2019 


\title{
HEALTH RISK ANALYSIS RELATED TO ORGANIZATIONAL TASKS IN PUBLIC HEALTHCARE
}

UDC $61.002(075.8)$

DOI: $10.21668 /$ health.risk/2019.3.17.eng

\section{INFORMATION TECHNOLOGIES FOR DATA COLLECTION AND PROCESSING WHEN ESTABLISHING DETERMINANTS OF EPIDEMIC PROCESSES}

\author{
A.V. Bogomolov, S.S. Chikova, T.V. Zueva \\ State Research Institute for Military Medicine, $7,1^{\text {st }}$ Krasnokursantsky proezd, Moscow, 111250, Russian Federation
}

Providing biological safety of population is determined by a current situation with the state sanitary-epidemiologic system and its being ready to detect, localize and eliminate infective episodes. As threats of bioterrorism attacks against people are growing and infectious diseases are becoming more widely spread, it calls for greater efficiency of sanitary-epidemiologic examinations due to optimized collection and processing of data that are necessary for decision making related to revealing basic determinants of an epidemic process, as well as causes and conditions for infection occurrence and spread.

The paper dwells on a technology for automated data processing that helps to efficiently reveal all determinants of an epidemic process, and causes and conditions for infection occurrence and spread. The technology also allows automated checking of all proposed hypotheses basing on generalization of results obtained via independent research.

Proposed solutions are verified within a sanitary-epidemiologic examination that focused on dysentery episode in an organized team with its members staying on a closed territory and having their meals provided for them at a canteen. The authors compared an already existing system for collection and processing of statistical data (applied to reveal basic determinants of an epidemic process) and a proposed system for data collection and processing.

Obtained results supplement and develop existing theoretical and practical achievements as regards IT implementation into sanitary-epidemiologic examinations; they have considerable practical significance especially bearing in mind a future transition to electronic circulation of documents within public healthcare and medical provision. When applied, a proposed approach allows considerable reduction in time spent on generalization of data obtained via sanitary-epidemiologic examinations as well as a significant increase in validity of accomplished statistical calculations necessary to reveal factors that cause infectious agent transmission.

Key words: sanitary-epidemiologic examination, epidemiological analysis, health risks, infectious diseases risks, infection focus, determinant of en epidemic process, infectious agent, evidence-based medicine, medical information science, medical cybernetics.

Biological terrorism is a grave problem related to providing biological safety nowadays as biological terroristic attacks on people are becoming more and more probable and there is a growing threat that infectious diseases will spread rapidly [1-3]. But it is much more probable to face a biological terroristic act that is not clearly obvious when it is too difficult to track cause-and-effect relations and determine an actual goal pursued by terrorists who applied biological agents [4-6].
State sanitary-epidemiologic surveillance should prevent occurrence and spread of hazardous infectious diseases that can cause mass outbreaks and epidemics. In this respect biological safety provision is determined by a system of state sanitary-epidemiologic surveillance being well-developed and well-prepared to detect, localize, and eliminate infective episodes [2, 7-9]. To work out efficient and timely activities aimed at minimizing consequences, localizing, and eliminating infective

(C) Bogomolov A.V., Chikova S.S., Zueva T.V., 2019

Aleksei V. Bogomolov - Doctor of Technical Sciences, Professor, Deputy Head of the Research and Testing Center for Military Medicine (e-mail: a.v.bogomolov@gmail.com; tel.: +7(495)612-80-31; ORCID: https://orcid.org/0000-0002-7582-1802).

Svetlana S. Chikova - Candidate of Medical Sciences, Associate Professor, Head of the Department for Military Epidemiology (e-mail: a.v.bogomolov@gmail.com; tel.: +7(495)612-80-31; ORCID: https://orcid.org/0000-0002-8765-5832).

Tatyana V. Zueva - Candidate of Technical Sciences, Associate Professor, Leading Researcher at the Department for Military Epidemiology (e-mail: a.v.bogomolov@gmail.com; tel.: +7(495)612-80-31; ORCID: https://orcid.org/0000-0002-0981-8102). 
episodes, one should make sanitary-epidemiologic investigations as efficient as it's only possible $[10,11]$. At present, as a number of sanitary-epidemiologic institutions is being gradually reduced but a number of object under surveillance, on the contrary, is growing, issues related to staff, material, and instrumental provision call for implementing information technologies (IT) that can support managerial decision-making [11-14].

Automated systems for control over various infectious nosologies are widely used in Western European countries and the USA [13-19]. The most widely used systems are Germ Alert, Germ Watcher, Gideon, RODS, and EpidInfo. Analysis revealed that Gideon and EpidInfo systems were the most efficient as regards finding solutions to outstanding tasks; these systems are aimed at monitoring morbidity with infectious diseases and analyzing monitoring data. However they can't be efficiently applied in Russian public healthcare as they are built taking into account organizational structures in public healthcare, reports and accounts, and peculiarities related to providing medical assistance to population in a specific country.

Domestic automated systems applied for control over morbidity with infectious diseases are aimed at keeping accounts and control over circulation of documents and at analyzing data including those on morbidity with infectious diseases as well as data on a sanitary-epidemiologic situation at objects under surveillance. However, none of such systems can provide automated collection, processing and analysis of data directly at foci where mass infective episodes occur; they don't allow revealing main determinants in epidemic processes and methods to eliminate basic ways and factors of contagion in organized teams. There are several problems related to creation of such systems; for example, there is a necessity to create algorithms for processing results obtained via clinical examinations and epidemiologic case histories; another problem is a necessity to formalize certain technological processes related to obtaining primary data on a disease from variable sources [20-23].
Sub-systems for monitoring over hazardous infectious diseases, analysis of data obtained via clinical and laboratory examinations of patients and reference data are basic components in automated systems that provide information support for decision-making when sanitary-anti-epidemic (preventive) activities take place [15-19]. It is also necessary to have a possibility to model epidemics scenarios depending on an infectious agent, preventive measures that were taken, and potential ability to eliminate an infectious focus [20-22].

Efficiency of anti-epidemic activities and medical aid for people who suffer from infectious diseases is determined by clinical and epidemiologic diagnostics being efficient and correct; these activities should also be timely and it to a great extent depends on how rapidly basic determinants of an epidemic process and causes for an infective episodes have been revealed $[6-8,10-13,15,17,20]$. When an epidemic is at its peak and patients with typical clinical symptoms are submitted to hospitals in great numbers, it is, as a rule, quite easy to determine a nosology, and causes for its occurrence and spread, especially in such cases when it concerns epidemic outbreaks that are well-known to physicians (shigellosis, flu, viral hepatitis, etc.). However, there may be infective episodes of diseases that are not so well-known, such as cholera, hemorrhagic fever with renal syndrome, malaria, contagious hemorrhagic viral fevers, etc.; they can occur both due to natural causes and biological terroristic acts when a clinical course of a disease can't be limited to only one nosology [10-27]. Therefore, to determine how an infectious agent is transferred in case of a mass infective episode, it is important to apply a principle of clinical-syndrome diagnostics (when major symptoms of a disease are revealed). Data taken from epidemiologic case histories and data obtained via operative epidemiologic analysis can be of critical importance for localizing and eliminating a focus of mass infectious diseases [1-10].

Our research can be considered vital due to Russian public healthcare being devoid of the above-mentioned sub-systems that are adapted 
to peculiarities of data collecting and processing when mass infections foci are localized and eliminated; such systems should take into account all the contemporary achievements in medical informatics.

It is vital to determine basic ways and factors that induce contagion; to do that, experts who perform sanitary-epidemiologic investigaions simultaneously detect infected people and those who were exposed to risks of contagion, question and examine them, process data and analyze obtained results [23-29]. Such examinations are based on questioning that, as a rule, is a primary tool for collecting complaints and symptoms of a disease that allow preliminary diagnosing and assuming how an infectious agent can spread and be caught; they also allow collecting data for epidemiologic case histories or data on consumed food products [30-34].

Our research goal was to increase efficiency of sanitary-epidemiologic investigations in mass infections foci due to streamlined collecting and processing data necessary to support decision-making related to revealing basic determinants in an epidemic process as well as causes and conditions for infection occurrence and spread.

Data and methods. Our research was simultaneously focused on detecting infected people and those who had been exposed to risks of contagion, questioning and examining them, data processing and analysis of obtained results. People who had been exposed to risks of contagion were detected via questioning, with its results being consequently processed.

As typical questionnaires for patients recommended to be applied in such investigations don't provide any possibility to automatically process questioning results, we developed new questionnaires to be applied for collecting and processing data in a mass infection focus (for acute enteric infections). Questionnaires included data on infected people and those who had been exposed to risks of contagion with a possibility to provide console or optical data input for consequent automated processing of results.
Questionnaires had a reference-identification block (personal data), and two basic parts; one of them had to be filled in by a patient, another one, by a doctor (medical assistant). Table 1 contains a part of such a questionnaire as an example.

Table 1

A questionnaire (a fragment)

\begin{tabular}{|l|l|}
\hline \multicolumn{2}{|c|}{ To be filled in by a patient } \\
\hline 1. Complaints: & $\square-$ no; $\square-$ yes \\
\hline - headache & $\square-$ no; $\square-$ yes \\
\hline - overall weakness & $\square-$ no; $\square-$ yes \\
\hline - fever & $\square-$ no; $\square-$ yes \\
\hline .. & $\square-$ no; $\square-$ yes \\
\hline 2. Participating in: & $\square-$ no; $\square-$ yes \\
\hline - field exercises & $\square-$ no; $\square-$ yes \\
\hline - constructing & $\square-$ no; $\square-$ yes \\
\hline - agricultural work
\end{tabular}

3. Water consumption:

- from non-centralized water sup- $\mid \square-$ no; $\square-$ yes ply sources

\begin{tabular}{l|l} 
- potable water & $\square-\mathbf{n o} ; \square-$ yes \\
\hline
\end{tabular}

- from open water reservoirs $\quad \square-$ no; $\square-$ yes

4. Contacts with infected people $\square-\mathbf{n o} ; \square-$ yes

5. Mechanical damage to skin:

\begin{tabular}{|l|l|}
\hline - mosquito bites & $\square-$ no; $\square-$ yes \\
\hline$\ldots$ & \\
\hline- visit to a dentist & $\square-$ no; $\square-$ yes \\
\hline- injections & $\square-$ no; $\square-$ yes \\
\hline 6. Da on nution
\end{tabular}

6. Data on nutrition

1.Organized nutrition according to fixed rations:

\begin{tabular}{|l|l|}
\hline 1 control day & \\
\hline - cutlet & $\square-$ no; $\square-$ yes \\
\hline - stewed meat & $\square-\mathbf{n o} ; \square-$ yes \\
\hline - mashed potatoes & $\square-$ no; $\square-$ yes \\
\hline - buckwheat cereal & $\square-$ no; $\square-$ yes \\
\hline$\ldots$ & \\
\hline 2 control day & \\
\hline$\ldots$ & $\square-$ no; $\square-$ yes \\
\hline
\end{tabular}

2. Additional list of products in non-organized rations

\begin{tabular}{|l|l|}
\hline- curds & $\square-$ no; $\square-$ yes \\
\hline- sour cream & $\square-$ no; $\square-$ yes \\
\hline - kefir & $\square-$ no; $\square-$ yes \\
\hline$\ldots$ & \\
\hline \multicolumn{2}{|c|}{ To be filled by a doctor } \\
\hline Symptoms \\
\hline 1. beginning of a disease & $\square-$ no; $\square-$ yes \\
\hline - acute
\end{tabular}


Information technologies for data collection and processing when establishing determinants of epidemic processes

\begin{tabular}{|c|c|}
\hline - sub-acute & $\square-$ no; $\square-$ yes \\
\hline - slowly progressive & $\square-$ no; $\square-$ yes \\
\hline \multicolumn{2}{|l|}{ 2. Overall state a patient is in } \\
\hline - satisfactory & $\square-$ no; $\square-$ yes \\
\hline - average gravity & $\square-\mathrm{no}$; $\square-$ yes \\
\hline - grave & $\square-$ no; $\square-$ yes \\
\hline \multicolumn{2}{|l|}{ 3. Body temperature } \\
\hline - a drastic rise & $\square-$ no; $\square-$ yes \\
\hline- up to $38^{\circ} \mathrm{C}$ & $\square-$ no; $\square-$ yes \\
\hline$-38^{\circ} \mathrm{C}$ and more & $\square-$ no; $\square-$ yes \\
\hline \multicolumn{2}{|l|}{ 4. Skin and mucous tunics } \\
\hline$\ldots$ & $\square-$ no; $\square-$ yes \\
\hline \multicolumn{2}{|l|}{ 5. coated tongue } \\
\hline & $\square-$ no; $\square-$ yes \\
\hline \multicolumn{2}{|c|}{ 6. State of the digestive organs } \\
\hline . & $\square-$ no; $\square-$ yes \\
\hline 7. Tachycardia & $\square-$ no; $\square-$ yes \\
\hline 8. Bradycardia & $\square-$ no; $\square-$ yes \\
\hline 9. Low blood pressure & $\square-$ no; $\square-$ yes \\
\hline 11. High blood pressure & $\square-$ no; $\square-$ yes \\
\hline 10. Enlarged liver & $\square-$ no; $\square-$ yes \\
\hline 11. Enlarged spleen & $\square-$ no; $\square-$ yes \\
\hline 12. Decreased daily diuresis & $\square-$ no; $\square-$ yes \\
\hline
\end{tabular}

A part of the questionnaire that was to be filled by a patient (or, following his or her words, by a medical expert) involved filling in basic complaints and data for epidemiologic case history. The other part that was to be filled by a doctor enlisted basic symptoms acute enteric infections might have (primary clinical signs that were characteristics for certain acute enteric infections such as dysentery, viral hepatitis of A type, cholera, salmonellosis, and yersiniosis).

To avoid incorrect filling in questionnaires and to make analyzed data more valid, experts applied a system of predicates thus automatically checking whether questionnaires were filled correctly; this system allowed controlling data input and warning a doctor that there was probably a mistake in data input or certain data had been inputted incorrectly.

For example, high body temperature $\left(T_{1}\right)$ can't go with normal $\left(T_{2}\right)$ or low $\left(T_{3}\right)$ temperature. Therefore, when a predicate $P(T)=$ if ( $T_{1}=$ true and $T_{2}=$ true) or $\left(T_{1}=\right.$ true and $T_{3}=$ true) or $\left(T_{2}=\right.$ true and $T_{3}=$ true $)$ or $\left(T_{1}=T_{2}=T_{3}\right)$ has "ture" value, it means that data on complaints and symptoms of a diseases have been incorrectly filled in a questionnaire.
We worked out our algorithm for a sanitary-epidemiologic investigation aimed at determining basic ways and factors of contagion; this algorithm involved applying our developed questionnaires and could be considered a functional model for technological processes aimed at localizing and eliminating a mass infection focus; the model also included relevant information flows and was completed with Ross' notations (IDEF0), Gane - Sarson's notations (DFD), and Integrated Definition for Process Description (IDEF3) within All Fusion Process Modeler 4.1 data modeling system; its description can be found in $[17,19]$.

Data that were contained in questionnaires (complaints, symptoms, epidemiologic case histories, and data on consumed food products and drinks) were processed with a technology that allowed us to generalize results of independent research in order to check suggested hypotheses, or so called meta-analysis [11, 35-37]. Algorithms applied for data processing in metaanalysis procedures and interpreting its results are described in [35].

Research results. Suggested solutions were verified during an investigation that was aimed at revealing reasons for several mass infective episodes. We compared an existing system for collecting and processing data related to statistical parameters (the system was applied to detect basic determinants for epidemiologic processes related to those episodes) and a system for data collecting and processing based on all the suggested solutions.

As an example, we can consider results obtained during an investigation that focused on dysentery outbreak in an organized team; team members lived compactly on a closed territory and were provided with organized meals. 52 out of 160 team members caught dysentery $(32.5 \%)$; 13 people fell sick on the first day; 16 , on the second day; 11, on the third day; 7 , on the fourth day; 3 , on the fifth day; and 2, on the sixth day.

Our suggested approach involved filling in questionnaires both by those who had dysentery and those who ran a risk of contagion (control group); all the questionnaires were processed according to the following procedure. 
On the first day when the disease was detected we input information into the database that included both data from questionnaires filled in by those who felt sick on that day and by those who didn't (the control group). On the second day we questioned only those who felt sick on that day and didn't question healthy people (as we already had data on them filled in on the first day) etc. Starting from the second day, we created an intermediate summary table with data both on those who fell sick and the control group.

For example: 13 people fell sick on the first day and the control group included 147 people; 16 people fell sick on the second day and the control group now included only 131 people, etc. On the second day the summary table contained data on 29 sick people and 118 healthy ones in the control group. The same summary tables were created for each following day during the outbreak until new patients ceased to be revealed. Accordingly, after all the data from filled questionnaires were fed and processed in a PC, the following reports were automatically created:

1. A number of people who fell sick as per dates and isolation, affection as per divisions in an organized team, summing up quantity of sick people as a progressive total, as well as a typical graph showing dynamics of the disease development ( $\mathrm{X}$ axis showed dates of contagion; $\mathrm{Y}$ axis, a number of people who fell sick on a particular day).

2. Complaints and symptoms. Basic complaints that we received from people during the inspection were headache (71\% sick people), thirst, dry mouth ( $85 \%$ and $98 \%$ respectively); colickly abdominal pains (65\%). $65 \%$ and $100 \%$ sick people complained they had tenesmus and diarrhea. The results were presented both in tables and on graphs.

There were the following basic symptoms: acute onset of the disease involved drastic temperature rise up to $39^{\circ} \mathrm{C}$, patients were mostly in average gravity state, pains and spasms in the sigmoid section of the intestines were revealed in $77 \%$ patients; $67 \%$ and $46 \%$ patients had frequent liquid stool with mucus and blood respectively.

We analyzed the obtained results and revealed prevailing complaints and symptoms that were typical for damage to the gastrointestinal tract; it allowed a doctor to preliminary diagnose a disease and suggest a hypothesis that an infective episode was somehow related to contagion with food.

3. Data taken from epidemiologic case histories should include probable risk factors related to consuming water from non-centralized water supply systems, low quality food products, staying on geographically remote territories, possible contacts with infected people etc.

As all the sick people didn't attend any field activities during incubation, didn't take part in agricultural works, and didn't drink water from non-centralized water supply systems, contagion was the most likely caused by sanitary-epidemiologic rules being violated during cooking.

4. Reports on nutrition received by sick people and the control group were presented in the aggregate table. Dishes were selected from everyday menus by epidemiologists. In our examined case we took two menus, 2 and 3 days prior to the disease outbreak. We performed factor epidemiological analysis [24] to determine a specific product that was a possible factor causing contagion.

The aggregate table with data on nutrition contained results for each specific product that was included into menus; data included those on how many people (\%) who consumed this or that product were affected and on the control group (people who didn't consume it), as well as significance of a zero hypothesis ("there are no discrepancies between sick people and the control group") calculated with Pearson's $\chi^{2}$ test and the exact Fischer's test as per crosstabulation tables created for each product [35].

We performed factor analysis to reveal what product was a contagion factor; to do that, we examined both groups: people who had consumed a certain product and the control group (people who hadn't done it). We revealed how many disease cases occurred in each group after a specific food product had been consumed 2 days prior to the day when sick people were first detected and in how many cases there was absence of the above effect. 


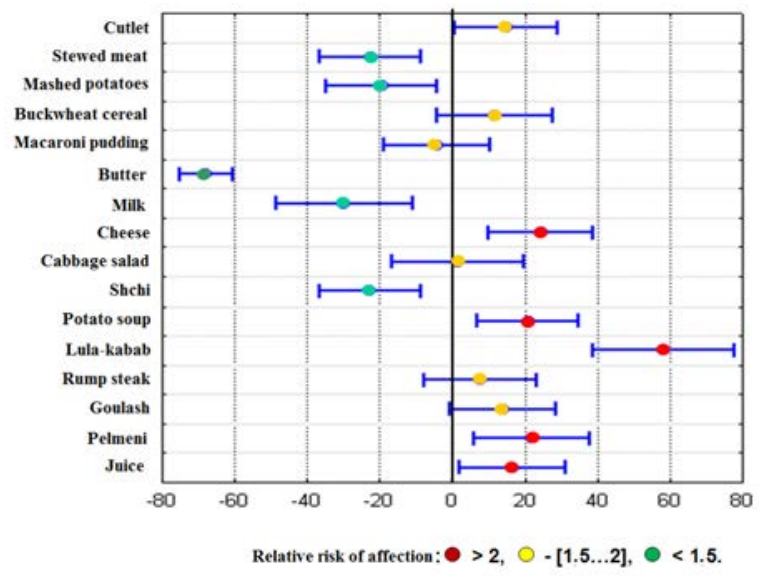

Figure 1. Visualized results of factor epidemiologic analysis (the first day of the inspection, a fragment)

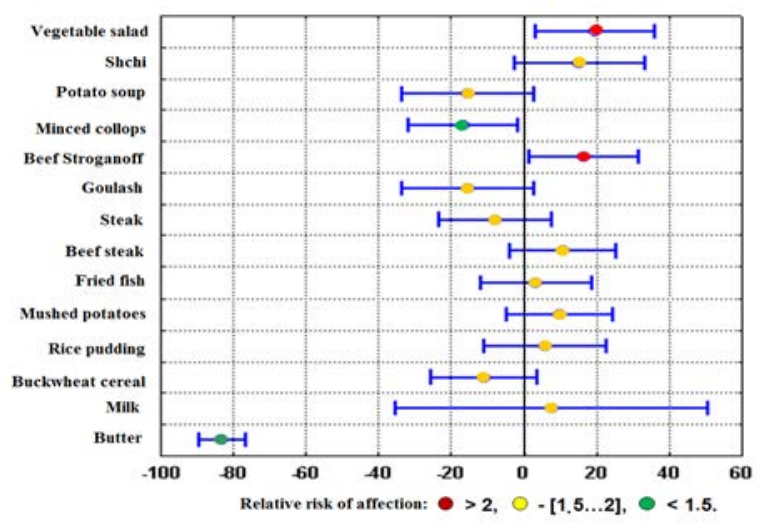

Figure 2. Visualized results of factor epidemiologic analysis (the second day of the inspection, a fragment)

Factor epidemiologic analysis aimed at determining a food product that was a contagion factor was performed in three stages: significance of a zero hypothesis was calculated; epidemiologic analysis results were visualized; absolute and relative risks were calculated.

Statistical properties related to authenticity of occurring effects caused by a specific product being consumed were calculated as per cross tabulation tables according to $[11,35]$; the results are shown in Figures 1 and 2.

$\mathrm{Y}$ axis shows a list of consumed food products; $\mathrm{X}$ axis shows a difference between disease cases among people who were exposed to a risk of contagion and in the control group. Segments that connect three given points for each product characterize how apparent the disease occurrence is and how valid a suggested hypothesis is. The more to the right is a segment relative to the zero $\mathrm{X}$ axis, the more apparent is the disease and the higher its validity. And a product is considered to be a probable contagion factor if $95 \%$ confidence interval is located strictly to the right from the zero $\mathrm{X}$ axis.

Thus, according to the research results (Figures 1 and 2), we can conclude that on the first day the most apparent effects indicating a product could be a contagion factor were detected for lula-kabab, cheese, potato soup, and pelmeni; effects were not so apparent for cutlets, buckwheat cereal, macaroni pudding, salad, rump steak, and goulash; there were no effects detected for stewed meat, mashed potatoes, butter, milk, and shchi.

As for products consumed on the second day, the most apparent effects were detected for vegetable salad and beef Stroganoff. Effects were either vague or absent for all the other products consumed on that day.

To confirm the obtained results, we calculated absolute and relative risks of contagion caused by consumption of the listed products (Table 2). The highest absolute and relative risks were detected for lula-kabab and cheese.

On the second day the highest absolute and relative risks were detected for salad and beef Stroganoff. But significance of a zero hypothesis was $p=0.09$ for vegetable salad and $p=0.08$ for beef Stroganoff, that is, it was higher than its critical value being equal to 0.05 .

Therefore, epidemiologic analysis as per risk factors based on analyzing cross tabulation tables and visualizing its results allowed us to reduce a list of products that could possibly cause contagion by $64 \%$ at the first two stages (determining significance of a zero hypothesis and visualizing research results); and by additional $30 \%$ at the third stage (calculating absolute and relative risks). We detected that only 4 out of total 28 products that could possibly be risk factors were the most probable causes of contagion (lula-kabab, cheese, potato soup, and pelmeni).

The obtained results were consistent with the data obtained via epidemiologic investigations on the infective episode and confirmed by laboratory research. 
Table 2

Affection, absolute, and relative risks of contagion caused by consumption of food products included into menus 2 days prior to the day when the first disease cases were registered (a fragment)

\begin{tabular}{|c|c|c|c|c|c|}
\hline \multirow[b]{2}{*}{ A food product } & \multicolumn{2}{|c|}{ Affection, $\%$} & \multirow{2}{*}{$\begin{array}{l}\text { Significance } \\
\text { of a zero } \\
\text { hypothesis }\end{array}$} & \multirow{2}{*}{$\begin{array}{l}\text { Absolute } \\
\text { risk }\end{array}$} & \multirow{2}{*}{$\begin{array}{l}\text { Relative } \\
\text { risk }\end{array}$} \\
\hline & $\begin{array}{l}\text { Among people who } \\
\text { consumed a product }\end{array}$ & $\begin{array}{l}\text { In the control } \\
\text { group }\end{array}$ & & & \\
\hline \multicolumn{6}{|c|}{ The $1^{\text {st }}$ day } \\
\hline Cutlet & 38.71 & 23.88 & 0.07 & 14.83 & 1.62 \\
\hline Stewed meat & 21.25 & 43.75 & 0.001 & -22.5 & 0.49 \\
\hline Macaroni pudding & 30.49 & 34.62 & 0.47 & -4.13 & 0.88 \\
\hline Butter & 32.08 & 100 & 0.019 & -67.92 & 0.32 \\
\hline Milk & 26.56 & 56.25 & 0.0006 & -29.69 & 0.47 \\
\hline Cheese & 46.38 & 21.98 & 0.0019 & 24.4 & 2.11 \\
\hline Lula-kabab & 85.71 & 27.4 & 0.0008 & 58.31 & 3.13 \\
\hline Rump steak & 37.5 & 29.81 & 0.42 & 7.69 & 1.26 \\
\hline Goulash & 40.28 & 26.14 & 0.083 & 14.14 & 1.54 \\
\hline Pelmeni & 47.17 & 25.23 & 0.009 & 21.94 & 1.87 \\
\hline \multicolumn{6}{|c|}{ The 2nd day } \\
\hline Vegetable salad & 35.56 & 16 & 0.09 & 19.56 & 2.22 \\
\hline Minced collops & 20 & 36.67 & 0.03 & -16.67 & 0.55 \\
\hline Beef Stroganoff & 36.67 & 20 & 0.08 & 16.67 & 1.83 \\
\hline Goulash & 29.03 & 44.44 & 0.05 & -15.41 & 0.65 \\
\hline Steak & 27.08 & 34.82 & 0.25 & -7.74 & 0.78 \\
\hline Milk & 32.69 & 25 & 0.82 & 7.69 & 1.31 \\
\hline Butter & 16.92 & 100 & 0 & -83.08 & 0.17 \\
\hline
\end{tabular}

When necessary, this algorithm can be applied to test other hypotheses on probable causes for contagion.

Therefore, when questioning results are properly processed, it allows timely determining a probable contagion factor; it is truly vital for performing efficient sanitary-epidemiologic investigaitons.

Discussion. Our assessments revealed that an epidemiologist on average spent 20-30 minutes per 1 patient to collect data on clinical signs of a disease and other necessary data for epidemiologic case history. When an infective episode is massive and 15-25 people fall sick every day, it takes on average 2-3 hours to create analytical tables, generalize, and analyze available data.

Our research revealed that the suggested approach allowed a substantial reduction in amount of time spent on generalizing all the obtained data; this amount dropped by more than 60 times, from 3 hours to 3 minutes. It also allowed making statistical calculations much more valid due to simultaneous use of several complimentary statistical techniques. The most significant time gain was obtained via applying optical input of data from formalized questionnaires.

Results that we obtained expand and develop the existing theoretical and practical experience in IT implementation into sanitaryepidemiologic research; they have great practical significance, especially bearing in mind a future transition to electronic circulation of documents within providing medical assistance to population.

The suggested way to implement IT into support for decision-making processes during sanitary-epidemiologic investigations allows optimizing collection and processing of data that are necessary to detect basic determinants of an epidemiologic process as well as causes and conditions of infection occurrence and spread. The achieved effect is higher efficiency in preparing data for factor epidemi- 
ologic analysis; timely detection of factors that determine contagion risks and risks of morbidity; revealing primary ways of contagion; and validity of obtained results.

Conclusions. To provide timely epidemiologic analysis that supports decisionmaking when basic determinants of an epidemic process are revealed is a primary goal to be achieved via optimizing collection and processing of data during sanitaryepidemiologic investigations in mass infections foci.

A questionnaire applied to collect primary data on sick people and those who ran risks of contagion was adapted for further processing with IT; it is a basis for data structuring when an acute enteric infection is preliminary diagnosed. This questionnaire contains sufficient amount of primary data on sick people that allows assessing health of any patient objectively and obtaining generalized data on a group of examined people.

Questioning results are automatically processed due to implementing optical data input with automated primary test of its correctness based on a system of predicates and consequent visualization of results obtained via statistical data processing. It provides a significant time gain and increases validity of initial data that are necessary to support decision-making during sanitary-epidemiologic investigations.

Suggested IT for data collection and processing during sanitary-epidemiologic investigations allow achieving more efficient collection and processing of initial data; providing greater validity of data analysis when revealing basic determinants of an epidemic process (due to simultaneous use of several complimentary statistical techniques); reducing time that is necessary to make a decision on anti-epidemic protection of population and to eliminate consequences of bioterrorism.

Funding. The research was not granted any financial support.

Conflict of interests. The authors declare there is no any conflict of interest.

\section{References}

1. Salagay O.O. Infectious disease control in the European Union: legal retrospective and modernity. Pravo i politika, 2015, no. 3, pp. 327-333. DOI: 10.7256/1811-9018.2015.3.14601 (in Russian).

2. Dyatlov I.A., Tyurin Ye.A. The public sanitary epidemiologic service supporting biological safety. Zdravookhraneniye Rossiyskoy Federatsii, 2013, no. 2, pp. 31-35 (in Russian).

3. Stachel A., Pinto G., Stelling J., Fulmer Y., Shopsin B., Inglima K., Phillips M. Implementation and evaluation of an automated surveillance system to detect hospital outbreak. Am. J. Infect. Control., 2017, vol. 45, no. 12, pp. 1372-1377. DOI: 10.1016/j.ajic.2017.06.031

4. Kettelhut V.V., Vanschooneveld T.C., McClay J.C., Mercer D.F., Fruhling A., Meza J.L. Empirical Study on the Impact of a Tactical Biosurveillance Information Visualization on Users' Situational Awareness. Mil. Med., 2017, no. 182, pp. 322-329. DOI: 10.7205/MILMED-D-16-00143

5. Khaustova N.A., Sokolova S.N. Safety of Modern Society: Nanotechnology and Bioterrorism. Vesník Paleskaga dzyarzhaŭnaga uníversíteta. Seryya gramadskíkh í gumanítarnykh navuk, 2015, no. 1, pp. 46-50 (in Russian).

6. Pukhov A.A. Bioterrorism and biodiversionary activity as threats to national security of the Republic of Belarus at present time. Vestnik Baranovichskogo gosudarstvennogo universiteta. Seriya: Istoricheskiye nauki i arkheologiya, Ekonomicheskiye nauki, Yuridicheskiye nauki, 2016, no. 4, pp. 132-137 (in Russian).

7. Konovalov P.P., Arsent'yev O.V., Buyanov A.L., Bekmurzov S.M. The use of biological weapons - realities of the contemporary world. Sibirskoye meditsinskoye obozreniye, 2015, no 4, pp. 79-84 (in Russian).

8. Banerjee D., Chakraborty B., Chakraborty B. Anthrax: Where Margins are Merging between Emerging Threats and Bioterrorism. Indian J. Dermatol., 2017, vol. 62, no. 5, pp. 456-458. DOI: 10.4103/ijd.IJD_378_17

9. Onishchenko G.G., Toporkov A.V., Lipnitskiy A.V., Viktorov D.V. Problems of counteraction to biological terrorism at the present stage. Infektsionnyye bolezni: novosti, mneniya, obucheniye, 2016, no. 1, pp. 24-31 (in Russian). 
10. Chen X., Chughtai A.A., MacIntyre C.R. A Systematic Review of Risk Analysis Tools for Differentiating Unnatural From Natural Epidemics. Mil. Med., 2017, vol. 182, no. 11, pp. 1827-1835.

11. Maksimov I.B., Stolyar V.P., Bogomolov A.V. Prikladnaya teoriya informatsionnogo obespecheniya mediko-biologicheskikh issledovanii [Applied theory of information provision for medical and biological research]. Moscow, Binom Publ., 2013, 311 p. (in Russian).

12. Solodovnikov Yu.P., Ivanenko A.V., Yefremova N.V., Filatov N.N., Glinenko V.M., Samchuk G.F., Ushakova N.S. Soderzhaniye i posledovatel'nost' professional'nykh deystvii epidemiologa pri rassledovanii vspyshek i epidemii kishechnykh infektsii [Contents and sequence of necessary steps an epidemiologist is to make when examining episodes and epidemics of enteric infections]. Zhurnal mikrobiologii, epidemiologii i immunobiologii, 2008, no. 1, pp. 101-105 (in Russian).

13. Marx V. High-security labs: Life in the danger zone. Nature, 2014, vol. 505, no. 7483, pp. 437-441. DOI: $10.1038 / 505437 \mathrm{a}$

14. Supotnitskii M.V. Recognition of Artificially Induced Outbreaks of Infectious Diseases. Aktual'naya infektologiya, 2014, no. 2, pp. 116-141 (in Russian).

15. Gerasimov A.N., Polibin R.V. Software for epidemiological analysis: Use and training. Epidemiologiya i infektsionnyye bolezni. Aktual'nyye voprosy, 2014, no. 5, pp. 75-78 (in Russian).

16. Parker J.T., Juren A.C., Lowe L., Santibañez S., Rhie G.E., Merlin T.L. Enhancing Laboratory Response Network Capacity in South Korea. Emerg. Infect. Dis., 2017, vol. 23, no. 13, pp. 120-124. DOI: $10.3201 /$ eid2313.170348

17. Bogomolov A.V., Zuyeva T.V., Chikova S.S. Informatsionno-logicheskaya model' protsessov sbora i obrabotki informatsii pri lokalizatsii i likvidatsii ochagov infektsionnykh zabolevaniy [Information and logic model for data collection and processing during localizing and eliminating infections foci]. Programmnyye produkty, sistemy i algoritmy, 2018, no. 1, pp. 7-10. DOI: 10.15827/2311-6749.18.1.2 (in Russian).

18. Muscatello D.J., Chughtai A.A., Heywood A., Gardner L.M., Heslop D.J., MacIntyre C.R. Translation of Real-Time Infectious Disease Modeling into Routine Public Health Practice. Emerg. Infect. Dis., 2017, vol. 23, no, 5, pp. 1-8. DOI: 10.3201/eid2305.161720

19. Zuyeva T.V. Strukturnyi sistemnyi analiz protsessov sbora i obrabotki informatsii pri provedenii sanitarno-epidemiologicheskikh rassledovaniy v voinskikh kollektivakh [Structural systemic analysis of data collection and processing when conducting sanitary-epidemiologic examinations in military teams]. Informatika i sistemy upravleniya, 2008, no. 2, pp. 74-76 (in Russian).

20. Zhdanov K.V., Zakharenko S.M., L'vov N.I., Kozlov K.V. Counteracting infections in the age of current threats. Infektsionnyye bolezni: novosti, mneniya, obucheniye, 2017, vol. 23, no. 6, pp. 85-91 (in Russian).

21. Belozerov Ye.S., Kiseleva L.M., Midlenko V.I., Kuz'mina A.A., Romanenko S.M., Reznikova Ye. N. Infectious diseases and problems of biosafety. Ul'yanovskii mediko-biologicheskii zhurnal, 2016, no. 3, pp. 8-15 (in Russian).

22. Gavrilova O.N., Kasymova R.O. Threats and approaches to improving epidemiological surveillance in the Kyrgyz republic as an element of biosecurity. Zdravookhraneniye Kyrgyzstana, 2017, no. 4, pp. 22-25 (in Russian).

23. Pokrovskii V.I., Briko N.I. Epidemiological studies are the basis for clinical epidemiology and evidence-based medicine. Epidemiologiya i infektsionnyye bolezni, 2008, no. 5, pp. 4-8 (in Russian).

24. Savilov Ye.D., Mamontova L.M., Astaf'yev V.A., Zhdanova S.N. Primeneniye statisticheskikh metodov $\mathrm{v}$ epidemiologicheskom analize [Application of statistical techniques in epidemiologic analysis]. Moscow, MEDpress-inform, 2004, 112 p. (in Russian).

25. Gerasimov A.N. Mathematical models and epidemiological analysis. Vestnik RAMN, 2010, no. 12, pp. 23-26 (in Russian).

26. Zavriyev S.K., Kolesnikov A.V. Risks and Threats in Biosecurity Area: Problem Analysis and Search for Optimal Solutions in Contemporary Conditions. Mirovaya ekonomika i mezhdunarodnyye otnosheniya, 2015, no. 9, pp. 57-68 (in Russian).

27. Willem L., Verelst F., Bilcke J., Hens N., Beutels P. Lessons from a decade of individual-based models for infectious disease transmission: a systematic review (2006-2015). BMC Infect. Dis., 2017, vol. 17, no. 1, pp. 612-619. DOI: 10.1186/s12879-017-2699-8 
28. Rasulov D.G. Biologicheskiy terrorizm kak Sistema [Biological terrorism as a specific system]. Vestnik Tadzhikskogo natsional'nogo universiteta. Seriya sotsial'no-ekonomicheskikh i obshchestvennykh nauk, 2017, vol. 9, no. 2, pp. 280-285 (in Russian).

29. Konovalov P.P., Arsent'yev O.V., Buyanov A.L., Shperling N.V. International legal acts fixing basis of activity in fight with bioterrorism. Permskii meditsinskii zhurnal, 2015, vol. 32, no. 1, pp. 116-124 (in Russian).

30. Sammarco M.L., Ripabelli G., Tamburro M. Molecular epidemiology of infectious diseases: analytical methods and results interpretation. Ann Ig., 2014, vol. 26, no. 1, pp. 10-45. DOI: 10.7416/ai.2014.1956

31. Fleck-Derderian S., Shankar M., Rao A.K., Chatham-Stephens K, Adjei S., Sobel J., Meltzer M.I., Meaney-Delman D., Pillai S.K. The Epidemiology of Foodborne Botulism Outbreaks: A Systematic Review. Clin. Infect. Dis., 2017, vol. 27, no. 66, pp. 73-81. DOI: 10.1093/cid/cix846

32. Vinarti R., Hederman L. A Knowledge-Base for a Personalized Infectious Disease Risk Prediction System. Stud Health Technol. Inform., 2018, no. 247, pp. 531-535.

33. Lall R., Abdelnabi J., Ngai S., Parton H.B., Saunders K., Sell J., Wahnich A., Weiss D., Mathes R.W. Advancing the Use of Emergency Department Syndromic Surveillance Data, New York City, 2012-2016. Public. Health Rep., 2017, vol. 132, no. 7, pp. 23-30. DOI: 10.1177/0033354917711183

34. Liao Y., Xu B., Wang J., Liu X. A new method for assessing the risk of infectious disease outbreak. Sci. Rep., 2017, no. 9, pp. 7. DOI: 10.1038/srep40084

35. Bogomolov A.V., Kukushkin Yu.A. Mathematical support for meta-analysis of independent experimental biomedical research. Informatika i sistemy upravleniya, 2011, no. 4, pp. 65-74 (in Russian).

36. Bogomolov A.V., Zuyeva T.V., Chikova S.S., Golosovskiy M.S. Ekspertno-analiticheskoye obosnovaniye prioritetnykh napravleniy sovershenstvovaniya sistemy preduprezhdeniya biologicheskikh terroristicheskikh aktov [Expert and analytic substantiation for priorities in development of a system aimed at preventing biological terrorist attacks]. Informatika i sistemy upravleniya, 2009, no. 4, pp. 134-136 (in Russian).

37. Bukhtiyarov I.V., Kukushkin Yu.A., Bogomolov A.V., Vasilyev A.Yu., Yadov V.V. Мeтa-analysis of the cumulative effects of piloting g-loads on the cervical vertebrae. Aviakosmicheskaya i ekologicheskaya meditsina, 2001, vol. 35, no. 3, pp. 18-24 (in Russian).

Bogomolov A.V., Chikova S.S., Zueva T.V. Information technologies for data collection and processing when establishing determinants of epidemic processes. Health Risk Analysis, 2019, no. 3, pp. 144-153. DOI: 10.21668/health.risk/2019.3.17.eng

Received: 18.02 .2019

Accepted: 26.07.2019

Published: 30.09.2019 
UDC 614.446: 1: 613: 11: 613.67

DOI: $10.21668 /$ health.risk/2019.3.18.eng

\title{
RISK ASSESSMENT FOR INCIDENCE WITH COMMUNITY-ACQUIRED PNEUMONIA IN ORGANIZED COMMUNITIES AMONG THIER MEMBERS ADAPTING TO TRAINING AND ACCLIMATIZATION
}

\author{
R.S. Rakhmanov ${ }^{1}$, N.N. Potekhina ${ }^{1}$, A.V. Tarasov ${ }^{2}$, I.N. Koldunov ${ }^{2}$ \\ ${ }^{1}$ Privolzhsky Research Medical University, 10/1 ploshchad' Minina i Pozharskogo, Nizhnii Novgorod, 603005, \\ Russian Federation \\ ${ }^{2}$ Immanuel Kant Baltic Federal University, 14 A. Nevskogo Str., Kaliningrad, 236016, Russian Federation
}

There is a pressing issue in prevention medicine related to improving approaches to detecting risk factors and reducing incidence with community-acquired pneumonia (CAP). Such approaches include analyzing health risks associated with adverse impacts exerted by environmental factors.

Our research goal was to assess incidence with CAP in initially healthy organized communities made up of cadets under influences exerted by a set of factors related to a body adapting to training at higher military educational establishments as well as to specific sea climate in Kaliningrad enclave.

We applied epidemiologic analysis to assess incidence with CAP in educational establishments with different training conditions. We determined peculiarities related to registering disease cases among local students and those who came from other Russian regions; we also comparatively analyzed annual incidence among first-year cadets.

Incidence among first- and second-year cadets was authentically higher than among senior ones. First-year students accounted for the greatest share in the overall incidence and it proved that adaptation to training was a truly significant factor. Incidence among cadets from other regions was higher and it proved that acclimatization to specific climatic and weather conditions was also a significant factor. Higher incidence among cadets who had poorer training conditions during their first and second training year confirmed that training conditions could also be considered a risk factor that caused CAP. Two peaks in annual morbidity among first years cadets were likely due to both a factor related to a new organized community formation and seasonal factors.

The fact that the disease is detected among cadets at each year makes it necessary to analyze incidence with CAP in order to detect probable "specific" risk factors and to provide differentiated prevention for each year.

Key words: educational establishments, cadets, community-acquired pneumonia, incidence, study cohorts, relative risk.

Community-acquired pneumonia (CAP) remains a significant social issue being a widely-spread disease among civilians and military personnel [1-3]. As per data provided by Rospotrebnadzor, in 2017 incidence with the disease amounted to 412.32 cases per 100 thousand people ${ }^{1}$. A number of virus pneumonia cases went down by 2 times against the previous year together with a registered decrease in incidence with flu; but there were practically no changes in a number of bacterial CAP cases and the incidence in 2017 was $4.3 \%$ higher than in 2016.

Children are the primary risk group as per CAP as the maximum incidence with the disease was registered among children aged 1-2 $(1,470.06$ per 100 thousand children of this age) [4], other risk groups include adults who suffer from pathologies in the upper respiratory tracts, overweight, pancreatic diabetes,

(C) Rakhmanov R.S., Potekhina N.N., Tarasov A.V., Koldunov I.N., 2019

Rofail' S. Rakhmanov - Doctor of Medical Sciences, Professor at the Hygiene Department (e-mail: raf53@mail.ru; tel.: +7 (910) 792-89-82; ORCID: https://orcid.org/0000-0003-1531-5518).

Natal'ya N. Potekhina - Doctor of Medical Sciences, Professor at the Hygiene Department (e-mail: nn-potechina@yandex.ru; ORCID: ORCID: https://orcid.org/0000-0001-6519-5513).

Andrei V. Tarasov - Candidate of Medical Sciences, Associate Professor at the Fundamental Medicine Department (e-mail: drup1@yandex.ru; tel.: +7 (911) 468-15-31; ORCID: https://orcid.org/0000-0001-5749-1216).

Ivan N. Koldunov - Candidate of Medical Sciences, Senior lecturer at the Therapy Department (e-mail: drup1@yandex.ru; tel.: +7 (952) 054-76-43; ORCID: https://orcid.org/0000-0001-7845-0800).

${ }^{1}$ On sanitary-epidemiologic welfare of the population in the Russian Federation in 2017: State Report. Moscow, The Federal Service for Surveillance over Consumer Rights Protection and Human Well-being Publ., 2018, 268 p. (in Russian). 
chronic lung and liver diseases, as well as reinforcements who start their military service [2, 5]. A factor related to adaptation and acclimatization was significant among students and cadets who attended higher educational establishments [6-12] and had to adapt themselves to specific occupational training [11]. A period during which there was a risk of an increase in incidence with CAP was determined for foreign students of a military HEE [6]; researchers also revealed a role played by seasonal acclimatization of the respiratory system (especially in September and October) in greater loads on the system accompanied with an increase in respiratory organs diseases [12]. Nevertheless, there has been no research or differentiated analysis on incidence with CAP among cadets in a specific climatic region only during a period of adaptation to training conditions as well as acclimatization to specific weather conditions.

To prevent CAP, there is immunization against pneumococcal infections both among children within the national prevention vaccination schedule (Prevenar-13 13-valent conjugated vaccine) and adults from risk groups (23-valent polysaccharide pneumococcal vaccine) that is quire efficient $[13,14]$. A set of preventive and anti-epidemic activities allowed to decrease incidence with CAP among draft military personnel from $69.6 \%$ in 2010 to $27.2 \%$ in 2017 , that is, by 2.6 times. However, this incidence still remains high in comparison to current incidence among contracted military personnel $(5.3 \%$ ) and population $(8.8 \%)$ [15].

Therefore, there is still a vital issue in practical medicine regarding improved approaches to risk factors determination and a decrease in CAP incidence. Several authors state it is necessary to create and implement programs aimed at preventing respiratory organs diseases, and at modeling criteria for determining risk groups as per bronchopulmonary pathology $[6,12]$. Such mechanisms include health risk analysis methodology which can be applied to analyze risks caused by negative impacts exerted by adverse environmental factors [16].
Our research goal was to assess incidence with CAP among initially healthy cadets from organized teams under influences exerted by a set of factors related to a body adapting to training conditions at a military HEE and acclimatization to sea climate in $\mathrm{Ka}-$ liningrad enclave.

\section{Research tasks:}

1. To apply epidemiologic analysis in order to assess incidence with communityacquire pneumonia at two military higher educational establishments with different training conditions;

2. To assess influence exerted by acclimatization on incidence with CAP among cadets from military HEE, both coming from Kaliningrad region and those who came to Kaliningrad enclave from other Russian regions;

3. To perform comparative analysis of annual incidence with CAP among first-years students at both establishments;

4. To determine relative risk of incidence with CAP in teams with synergic environmental factors that differed in their intensity.

Data and methods. We performed cohort studies at two military higher educational establishments in Kaliningrad region.

We accomplished a retrospective comparative analysis of incidence with CAP at two military HEE over 5 years (September 2012 - September 2017) under the same influences exerted by Baltic Sea climate. Cadets didn't have any preventive vaccination against CAP before they arrived at a HEE and during their training. Cadet teams had some differences in their parameters such as different occupational assignments, hygienic placement conditions, meals, and a ratio of cadets from Kaliningrad region and those who came from other regions. At the first HEE, shares of local students and those who came from other regions amounted to $57.7 \%$ and $42.3 \%$ : at the second one, $13.2 \%$ and $86.8 \%$ respectively.

Cadets from the first HEE lived in standard modern buildings and air per 1 person in first-year students bedrooms amounted to $16,3 \mathrm{~m}^{3}$, and in the second HEE, to $9,9 \mathrm{~m}^{3}$. Cadets from the 2nd HEE lived in premises 
built in 20-30ties of the 20th century (nonstandard buildings with basements). 20 cadets lived in each room, and air per 1 person in bedrooms for the first and second year students amounted to $9.9 \mathrm{~m}^{3}$; temperature inside might drop to $16-18^{0} \mathrm{C}$ in late September or early October, and there was increased humidity inside.

Meals were delivered by an outsource company (a choice of 3-4 dishes per each meal) or they were provided by HEE itself according to a ration schedule (one dish per a meal).

We assessed incidence (per 1 thousand people, \%o) as per training years (1-5) and determined peculiarities related to diseases registration from the 1 st to 5 th year. Applying the same approach, we assessed incidence among local cadets and those who came from other Russian regions. These data were considered to show dependence of the disease on natural resistance of a body and acclimatization. We examined annual and long-term dynamics of incidence.

We determined relative risks (OR) for incidence with CAP in cadet teams with different influences exerted by synergic environmental factors with a PC program.

The results were statistically processed with AtteStat software package. Validity of discrepancies between incidence levels was determined with Student's t-test.

Results and discussion. The climate in Kaliningrad enclave has some peculiarities that make it rather distinct from other regions in the Russian Federation:

1. Radiation balance is negative during four months (from November to February): substantial cloud cover reduces direct sun radiation income by $50-60 \%$;

2. The territory is exposed to cyclonic circulation for 173 days a year and it makes the sky cloudy and causes moderate and strong winds;

3. Relative air humidity is $81-82 \%$, but in autumn and winter it goes up to $85-89 \%$. High humidity and heavy cloudiness exert significant influence on changes in light conditions (there are only 30-33 sunny days a year);
4. Annually there are 178-183 days with precipitation in the region. There are also frequent fogs (in November-December and in March, they last for 30-40 hours) [8,9];

Diseases from the "Diseases of the respiratory system" category took the first rank place in the incidence structure at both HEE, accounting for $52.1 \%$ and $70.9 \%$ accordingly.

Over the analyzed period, incidence at the first HEE was 2.5 times lower than in the second one, $20.7 \pm 3,1 \%$ against $51.2 \pm 3,8 \%$, $\mathrm{p}=0.000$. We analyzed incidence as per training years and found out that authentic discrepancies occurred only during the 1st year as the figure was 2.52 times higher at the second HEE (Table 1).

Table 1

Incidence with CAP in two educational establishments as per training years, \%o

\begin{tabular}{|c|c|c|c|}
\hline \multirow{2}{*}{$\begin{array}{c}\text { Training } \\
\text { year }\end{array}$} & \multicolumn{2}{|c|}{ Compared groups } & \multirow{2}{*}{$\begin{array}{c}\mathrm{p}=\text { HEE } 1 / \\
\text { HEE } 2\end{array}$} \\
\hline & HEE 1 & HEE 2 & \\
\hline 1 & $46.9 \pm 8.2$ & $118.2 \pm 9.6$ & 0.000 \\
\hline 2 & $\begin{array}{l}22.8 \pm 6.2 \\
p=0.019^{*}\end{array}$ & $\begin{array}{l}34.3 \pm 6.1 \\
p=0.000 *\end{array}$ & 0.188 \\
\hline 3 & $\begin{array}{c}6.3 \pm 3.6 \\
\mathrm{p}=0.022^{* *}\end{array}$ & $\begin{array}{c}7.5 \pm 3.3 \\
p=0.000 * *\end{array}$ & 0.808 \\
\hline 4 & $3.3 \pm 3.3$ & $9.9 \pm 4.9$ & 0.274 \\
\hline 5 & $6.5 \pm 6.5$ & $4.0 \pm 4$ & 0.742 \\
\hline
\end{tabular}

Note: *p1-2;**p2-3.

Trends in incidence registration from the 1 st to 5 th year were quite similar at these two HEE as the absolute decrease amounted to $10.1 \%$ in the first one, and $28.5 \%$ in the second one, decrease rate being equal to $18.6 \%$ and $44.2 \%$ respectively. Incidence with CAP authentically decreased at the second training year, by 2.1 times at the first HEE $(p=0.019)$, and by 3.4 times, at the second one $(\mathrm{p}=0.000)$. However, it was still higher than at the 3rd training year, by 3.6 and 4.6 times respectively. And any discrepancies between incidence at the examined HEE disappeared only at the 3rd-5-th year.

Overall, incidence was higher among cadets who came from other regions than among local ones, by 2.0 times at the first HEE, and by 1.52 times, at the second one (Table 2 ). In 
turn, incidence among cadets was authentically higher at the second HEE than at the first one, by 2.6 and 3.0 times respectively.

Table 2

Incidence with CAP at two HEE among local cadets and those who came from other RF regions, \%o

\begin{tabular}{|c|c|c|c|}
\hline \multirow{2}{*}{ HEE } & \multicolumn{2}{|c|}{ Cadets } & \multirow{2}{*}{$\mathrm{p}=$ local/other } \\
\cline { 2 - 3 } & Local & $\begin{array}{c}\text { From other } \\
\text { regions }\end{array}$ & \\
\hline 1 & $14.2 \pm 3.9$ & $28.8 \pm 4.7$ & 0.017 \\
\hline 2 & $\begin{array}{c}43.0 \pm 10.2 \\
\mathrm{p}=0.008\end{array}$ & $\begin{array}{c}65.4 \pm 4.5 . \\
\mathrm{p}=0.000\end{array}$ & 0.046 \\
\hline
\end{tabular}

We analyzed incidence as per training years in both cadets cohorts and revealed the same dependence (Tables 3 and 4). Authentic discrepancies between incidence levels among local cadets and cadets from other regions were registered only at the 1st training year. Incidence was 3.0 times higher among cadets from other regions at the first HEE, and 1.74 times higher, at the second one. However, at the first HEE there were no discrepancies in incidence among local cadets between the 1st and the 2nd training year, but as for cadets from other regions, incidence at the 2 nd training year was 2.2 times lower than at the $1 \mathrm{st}$ one and there were no discrepancies in incidence levels at the 2nd and 3rd year.

As for the 2nd HEE, incidence with CAP was lower at the 2nd training year that at the 1st one, both among local cadets and those who came from other regions, by 1.7 times and 4.0 times respectively. There were no authentic discrepancies in it at the 3rd training year among local cadets, but incidence among cadets from other regions was 3.2 times higher. There were no discrepancies in incidence among local cadets and cadets form other regions at the 3rd - 5th training years.

We analyzed incidence with CAP among first-year cadets at the first HEE in its long-term dynamics and reveled a descending trend (an absolute annual decrease was equal to $8.5 \%$ o). Rises in incidence against the basic trend were detected in 2012-2013 and 2014-2015 training years. We detected an
Table 3

Incidence with CAP in the first HEE as per training years, \%o

\begin{tabular}{|c|c|c|c|}
\hline \multirow{2}{*}{$\begin{array}{c}\text { Incidence as } \\
\text { per training } \\
\text { years }\end{array}$} & \multicolumn{2}{|c|}{ Cadets } & $\mathrm{p}=$ local/ \\
\cline { 2 - 3 } other
\end{tabular}

Note: *p1-2; 2-3 etc.

Table 4

Incidence with CAP in the second HEE as per training years, $\%$ o

\begin{tabular}{|c|c|c|c|}
\hline \multirow{2}{*}{$\begin{array}{c}\text { Incidence as } \\
\text { per training } \\
\text { years }\end{array}$} & \multicolumn{2}{|c|}{ Cadets } & \multirow{2}{*}{$\begin{array}{c}\mathrm{p}=\text { local } / \\
\text { other }\end{array}$} \\
\hline & Local & $\begin{array}{c}\text { From other } \\
\text { regions }\end{array}$ & \\
\hline 1 & $75.2 \pm 22.9$ & $131.0 \pm 10.7$ & 0.027 \\
\hline 2 & $\begin{array}{c}44.2 \pm 19.3 \\
\text { p1-2 }=0.302^{*}\end{array}$ & $\begin{array}{c}32.9 \pm 0.6 \\
\mathrm{p} 1-2=0.000\end{array}$ & 0.578 \\
\hline 3 & $\begin{array}{c}11.8 \pm 11.7 \\
\text { p2-3 }=0.152\end{array}$ & $\begin{array}{c}10.3 \pm 4.2 \\
\mathrm{p} 2-3=0.003\end{array}$ & 0.909 \\
\hline 4 & $11.9 \pm 14.1$ & $9.9 \pm 4.9$ & 0.894 \\
\hline 5 & $16.9 \pm 16.8$ & $7.4 \pm 4.3$ & 0.582 \\
\hline
\end{tabular}

Note: *p1-2; p2-3 etc.

ascending trend in incidence at the second HEE with its absolute annual growth being equal to 28\% and rises in incidence in 2013-2014 and 2015-2016. In those years up to $80 \%$ disease cases were detected among first- and secondyear cadets, with first-year cadets accounting for $60 \%$ of them.

CAP cases were detected at both HEE year-round, however, the upper limit of allyear incidence (ULAYI) was 1.8 times higher at the second HEE than at the first one and amounted to $4.4 \%$ against $2.4 \%$ at the first HEE (Figure). Monthly incidence dynamics was the same and tended to have two seasonal rises, from August to December, and from February to March, however, their intensity was different as the peak incidence was 3.8 times 
higher at the second HEE during its epidemic rise and reached $22.2 \%$, against $5.9 \%$ at the first HEE and it means there were active risk factors at the second HEE.

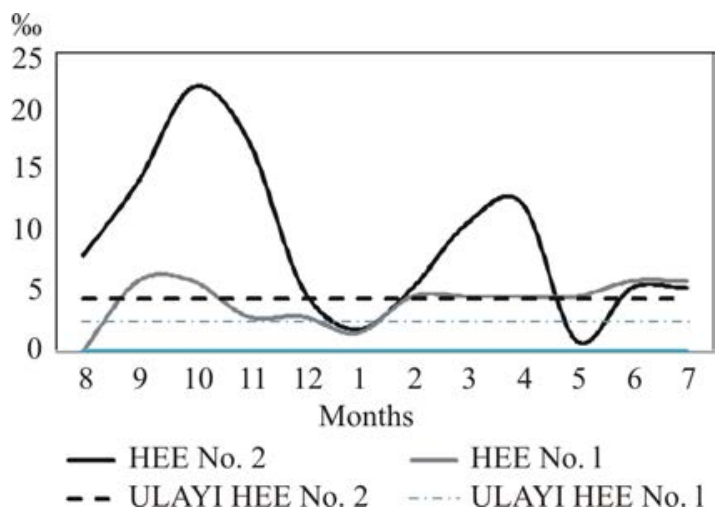

Figure. Annual incidence with CAP among first-year cadets, $\%$

Relative risk of incidence with CAP was higher at the second HEE than at the first one and amounted to 2.436 units; it was due to difference in influences exerted by synergic environmental factors. Relative risk of incidence with CAP among first- and second-year cadets was also higher, $\mathrm{OR}=2.411$ and $\mathrm{OR}=1.855$.

A set of these factors exerted more apparent impacts on incidence among cadets at the second HEE, both local ones and those who came from other Russian regions, $\mathrm{OR}=3.036$ and $\mathrm{OR}=1.932$.

Acclimatization-related processes in a body made their own contribution into incidence as it was proven by relative risk values at each HEE, its value being equal to 2.462 at the first HEE, and to 1.569, at the second one.

All the research results were obtained via analyzing incidence with CAP on a specific territory with its weather and climatic peculiarities. Physical environmental factors produced negative effects on health during different seasons [17-19]. Two rises in annual incidence among first-year cadets were probably caused by both factors related to a new team formation and seasonal factors. In its turn, incidence among cadets who came from other regions proved that adaptation mechanisms were a significant risk factor in case of such pathology.
Our research was based on the following propositions:

analysis performed on cohorts that include initially healthy people allows to reveal factors that play a significant role in epidemiologic process development and determine various "approaches" to preventing the disease;

total incidence and incidence with respiratory organs diseases to a certain extent reflects immunity level and characterizes how adapted young men are to training conditions [10];

health is an indicator related to influences exerted by synergic adverse environmental factors and training-related factors and it should be taken into account when implementing medical and preventive activities [11].

Analysis of incidence with CAP among initially healthy cadets who attended two HEE allowed to reveal the same peculiarities.

1. Average incidence with CAP was authentically higher among first- and secondyear cadets than among senior ones. First-year students accounted for the major share of incidence with CAP and it proved that a factor related to adaptation to training conditions was truly significant.

2. Incidence at each HEE had a correlation with a share of cadets who were not accustomed to local weather and climatic conditions; it proved that acclimatization factor was significant as adverse impacts exerted by Baltic Sea climate on health of cadets who came from other Russian regions became apparent via excess incidence. It allowed us to conclude that these weather and climatic conditions were clinically irritating for this category of people.

3. Training conditions also had their effects on incidence with CAP as it was proven by higher incidence among first- and secondyear students at the second HEE and it meant they were risk factors that could probably cause CAP.

4. Relative risks calculated among cadets from two HEE as per different training years and different cohorts (local cadets and those from other regions) proved that synergic environmental conditions exerted its influence on incidence with CAP. 
The obtained data allowed to conclude that first-year cadets ran the highest risks of CAP. Training conditions at a military HEE cause increased incidence both during the first and the second training year. Cadets who come to Kaliningrad enclave from other regions also run elevated CAP risks.

Disease registration that takes place at each training year determines the necessity to perform a retrospective analysis of incidence with CAP in order to reveal "specific" risk factors and probably differentiated activities aimed at CAP preventing among cadets at each training year.

Funding. The research was not granted any sponsor support.

Conflict of interests. The authors state there is no any conflict of interests.

\section{References}

1. Chuchalin A.G. Pneumonia as an actual medical problem of the 21th century. Russian Pulmonology. Terapevticheskii arkhiv, 2016, no. 4, pp. 4-1. DOI: 10.17116/terarkh20168834-12 (in Russian).

2. Ensuring sanitary and epidemiological welfare in the armed forces of the Russian Federation in 2017. Zdorov'e naseleniya i sreda obitaniya, 2018, vol. 298, no. 1, pp. 16-19 (in Russian).

3. Bilichenko T.N., Bystritskaya E.V., Chuchalin A.G., Belevskiy A.S., Batyn S.Z. Mortality of respiratory disease in 2014-2015 and ways of its improvement. Pul'monologiya, 2016, vol. 26, no. 4, pp. 389-397 (in Russian). DOI: 10.18093/0869-0189-2016-26-4-389-397

4. Mavzyutova G.A., Mukhamadieva L.R., Fazlyeva R.M., Mirsaeva G.Kh., Tyurina E.B. Rational immunotherapy in the combination treatment of community-acquired pneumonia. Meditsinskii sovet, 2015, no. 16, pp. 68-73 (in Russian).

5. Bilichenko T.N., Chuchalin A.G. Morbidity and mortality of the Russian population from acute respiratory viral infections, pneumonia and vaccination. Terapevticheskii arkhiv, 2018, no. 1, pp. 22-26 (in Russian). DOI: 10-17116/terarkh201890122-26

6. Balashov V.N., Udovichenko O.A., Evdokimov V.G. Climate impact on health and respiratory pathology development in foreign people studying at the Russian military academy. Byulleten' fiziologii i patologii dykhaniya, 2014, no. 51, pp. 69-74 (in Russian).

7. Rakhmanov R.S., Tarasov A.V. Otsenka riska zdorov'yu pri adaptatsii i akklimatizatsii v usloviyakh regiona Baltiiskogo morya [Health risk assessment for a period of adaptation and acclimatization to conditions existing in the Baltic Sea region]. Sovremennye metodologicheskie problemy izucheniya, otsenki i reglamentirovaniya faktorov okruzhayushchei sredy, vliyayushchikh na zdorov'e cheloveka: Materialy Mezhdunarodnogo foruma. Moscow, 2016, vol. 2, pp. 159-161 (in Russian).

8. Tarasov A.V. Otsenka riska dlya zdorov'ya u lits organizovannogo kollektiva $v$ usloviyakh adaptatsii [Health risk assessment for people from an organized community for a period of adaptation]. Sanitarnyi vrach, 2013, no. 9, pp. 42-44 (in Russian).

9. Tarasov A.V., Koldunov I.N., Rakhmanov R.S. On the issue of optimization of adaptation process to new environment taking into consideration climate and weather conditions. Gigiena $i$ sanitariya, 2014, no. 1, pp. 58-60 (in Russian).

10. Kolomiets O.I., Petrushkina N.P., Makunina O.A. Morbidity and vegetative status of the firstyear students as indicators of adaptation strategies to higher education. Uchenye zapiski, 2015, vol. 119, no. 1, pp. 97-104 (in Russian).

11. Kiku P.F., Mel'nikova I.P., Sabirova K.M. Hygienical assessment of factors of educational and production environment of cadets of higher marine educational institution. Ekologiya cheloveka, 2018, no. 3, pp. 21-26 (in Russian).

12. Grigor'eva E.A., Kir'yantseva L.P. Weather as a risk factor in respiratory morbidity and preventive measures among students. Byulleten' fiziologii i patologii dykhaniya, 2014, pp. 62-68 (in Russian).

13. Kozlova I.I., Sisin E.I., Ostapenko N.A., Ezhova O.A., Kashapov N.G. Analysis of the effectiveness of the implementation of the pilot project of vaccination against pneumococcal infection in risk groups in the municipalities leading on indicators of mortality from community-acquired pneumonia. Zdorov'e naseleniya i sreda obitaniya, 2018, vol. 298, no. 1, pp. 24-26 (in Russian).

14. Gruzdeva O.A., Bilichenko T.N., Vorontsova V.A, Uvarova A.A. Morbidity of influenza, other acute respiratory viral infections and pneumonia in population of the Central district of Moscow, 
2012-2016, and vaccine prevention. Pul'monologiya, 2017, vol. 27, no. 6, pp. 732-739 (in Russian). DOI: 10.18093/0869-0189-2017-27-6-732-739

15. Zhogolev S.D., Kulikov P.V., Zhogolev K.D., Aminev R.M., Zhogolev D.K., Zhurkin M.A., Kharitonov M.A., Gumilevskii B.Yu. Epidemiologicheskaya kharakteristika i sovershenstvovanie profilaktiki vnebol'nichnykh pnevmonii v voinskikh kollektivakh [Epidemiologic characteristics and improvement of prophylaxis activities aimed at preventing community-acquired pneumonia in military teams]. VI Luzhskie nauchnye chteniya. Sovremennoe nauchnoe znanie: teoriya i praktika: Materialy mezhdunarodnoi nauchnoi konferentsi. St. Petersburg, Leningradskii gosudarstvennyi universitet im. A.S. Pushkina Publ., 2018, pp. 145-148 (in Russian).

16. Onishchenko G.G. Health risk assessment and management as an effective tool to solve issues to ensure the health and epidemiological well-being of the Russian Federation population. Health Risk Analysis, 2013, pp. 4-14. DOI: 10.21668/health.risk/2013.1.01.eng

17. Rakhmanov R.S., Potekhina N.N., Grishin I.A., Piskarev Yu.G., Basalyga V.N., Sgibnev D.V., Mikhanoshina N.V., Tarasov A.V. Epidemiological features of communityacquired pneumonia under extreme natural-climatic conditions. Zdorov'e naseleniya i sreda obitaniya, 2017, vol. 289, no. 4, pp. 53-56 (in Russian).

18. Rakhmanov R.S., Potekhina N.N., Grishin I. A., Sgibnev D.V, Tarasov A.V. On prevention of community-acquired pneumonia among adults in organized groups. Zdorov'e naseleniya i sreda obitaniya, 2017, vol. 297, no. 12, pp. 29-33 (in Russian).

19. Mikhanoshina N.V. Zabolevaemost' lits organizovannogo kollektiva $\mathrm{v}$ razlichnykh pogodnoklimaticheskikh usloviyakh Dal'nego Vostoka [Incidence among people from organized communities under various natural and climatic conditions in the Far East]. Sanitarnyi vrach, 2013, no. 9, pp. 61-63 (in Russian).

20. Zhogolev S.D., Ogarkov P.I., Zhogolev K.D., Ivannikov Yu.G., Shipitsyn K.S., Kolesnikov V.V., Zharkov D.A. Epidemiology and prophylaxis of community-acquired pneumonia in servicemen. Voennomeditsinskii zhurnal, 2013, vol. 334, no. 11, pp. 55-60 (in Russian).

Rakhmanov R.S., Potekhina N.N., Tarasov A.V., Koldunov I.N. Risk assessment for incidence with community-acquired pneumonia in organized communities among thier members adapting to training and acclimatization. Health Risk Analysis, 2019, no. 3, pp. 154-160. DOI: 10.21668/health.risk/2019.3.18.eng

Received: 02.03.2019

Accepted: 26.07.2019

Published: 30.09.2019 
UDC 613.632.2

DOI: $10.21668 /$ health.risk/2019.3.19.eng

\title{
MODERN ASPECTS OF REGULATORY, PATHOPHYSIOLOGICAL AND TOXIC EFFECTS OF COBALT IONS DURING ORAL INTAKE IN THE HUMAN BODY
}

\author{
S.I. Dolomatov ${ }^{1}$, T.P. Sataeva ${ }^{1}$, W. Zukow ${ }^{2}$ \\ ${ }^{1}$ Medical Academy named after S.I. Georgievsky of Vernadsky Crimea Federal University, 5/7 Lenin Boulevard, \\ Simferopol, 295006, Russian Federation jurisdiction \\ ${ }^{2}$ Universitas Nicolai Copernici, 1 Lwowska Str., 87-100 Toruń, Poland
}

Cobalt is an essential microelement which is an indispensable part of several enzymes and co-enzymes. Cobalt ions may occur in the environment from both natural sources and due to human activities. This metal is very widespread in the natural environment and can be formed due to anthropogenic activity. Toxic effects produced by cobalt and its compounds depend on the physical and chemical properties of these complexes, including their electronic structure, ion parameters (charge-size relations) and kinetics. Cobalt has both beneficial and harmful effects on human health. Cobalt is beneficial for humans because it is a part of vitamin $B_{12}$, which is essential to maintain human health. If humans and animals are exposed to levels of cobalt normally found in the environment, it is not harmful. When excessive cobalt amounts enter a human body, multiple and chronic harmful health effects can occur and the longer the cobalt ions are stored in the body, the more changes they cause in cells. Cobalt gets into a body via several ways: mainly with food, via the respiratory system, through the skin or as a component of various biomaterials. Despite this metal being abundant, much of our knowledge on cobalt toxicity is based mainly on studies performed on animals. Undoubtedly, inorganic forms of cobalt are toxic as they accumulate in various tissues and can evoke a chain of pathological cascade changes in cells. Although some cobalt effects might be beneficial for medicine. Therefore, the purpose of our review is to provide the current analysis about the most significant regulatory, pathophysiological and epigenetic effects of $\mathrm{Co}^{2+}$ in a human body.

Key words: cobalt, $\mathrm{Co}^{2+}$ salts, $\mathrm{Co}^{2+}$ kinetics, heavy metal, cobalt toxicology, pathophysiology, epigenetics.

Introduction. The environmental pollution with xenobiotics is one of global unresolved problems, the relevance of which increased even more in the 21 st century. Among modern xenobiotics the leading position is occupied by salts of heavy nonferrous metals, which are extracted in large quantities into the human habitat. These include toxic trace elements such as: lead, cadmium, cobalt, chromium, mercury, aluminum, etc. Heavy nonferrous metals enter a body not only through the gastrointestinal tract, which is most vulnerable to effects produced by man-made exotoxicants, but also through the respiratory organs, integuments and mucous membranes, especially with decreased barrier functions.

According to the modern data rather high bioavailability of cobalt salts and the presence of metal mineral compounds in human trophic chains can be caused by both endemic geochemical factors and the human activity itself associated with the operation of coal-fired power plants, the production of certain foods, the mining and processing of metals, medical alloys, ceramics, household

(C) Dolomatov S.I., Sataeva T.P., Zukow W., 2019

Sergei I. Dolomatov - Candidate of Medical Sciences, Associate Professor at Department of Biology кафедры биологии (e-mail: path888d@yandex.ru; tel.: +7(3652)554-911; ORCID: https://orcid.org/0000-0001-7422-5657).

Tat'yana P. Sataeva - Candidate of Medical Sciences, Associate Professor at Department of Biology (e-mail: tanzcool@mail.ru; tel.: +7(3652)554-911; ORCID: https://orcid.org/0000-0001-6451-7285).

Walery A. Zukow - Candidate of Medical Sciences, Associate Professor at Faculty of Earth Sciences (e-mail: w.zukow@wp.pl; tel.: +48-601-92-55-95; ORCID: https://orcid.org/0000-0002-7675-6117). 
waste disposal, etc. There are numerous available data indicating a role diet plays in the intensity of cobalt entry into a human body [1-4]. The results of kinetics research on the bivalent cobalt ions $(\mathrm{Co} 2+)$ in a human body demonstrate that the maintenance of stable systemic indicators of this ion can be enhanced by binding the cation to plasma polyanion proteins (e.g. albumin); accumulation of significant amounts of $\mathrm{Co} 2+$ inside erythrocytes; its intense reabsorption by tubular nephron epithelium. The predominant pathways for cobalt excretion out of a human body or other mammals' ones are the kidneys and the gastrointestinal tract. The intensity of renal clearance of $\mathrm{Co} 2+$ rather accurately reflects the balance of the soluble ion fraction in the extracellular body fluid. A modern methodology for estimating the level of cobalt consumption by people can be based on analysis of the Co2+ dynamics in blood and urine [5-7]. Along with this, in population studies it is quite interesting to compare the dynamics of cobalt content in various human blood and hair samples. The parallel between the metabolic pathways in a human body of the $\mathrm{Ca} 2+$ and $\mathrm{Co} 2+$ cations is emphasized suggesting a preferential distribution of those cations in the intravascular fluid, in erythrocytes and in specialized cellular organelles of certain tissues with high rates of $\mathrm{Ca} 2+$ metabolism [8]. In particular, in experiments conducted on rats the cardiotoxic effect of bivalent cobalt salts was demonstrated mainly due to the accumulation of the $\mathrm{Co} 2+$ cation inside the cardiomyocytes. On the other hand, experimental evidence is given for the thesis stating that the intracellular metabolism of $\mathrm{Co} 2+$ may be closely linked with the metabolism of $\mathrm{Zn} 2+$ ions and the transport system of positively charged aminoacids through cationic amino acid transporter - Cat1 [9].

There are several reasons why the development of effective methods for assessing the levels of $\mathrm{Co} 2+$ intake and the study of its kinetics in a human body can have practical importance. Firstly, physiologically active $\mathrm{Co} 2+$-containing complex compounds (cobalamins) are vital for the normal biochemistry of physiological processes. Secondly, cobalt mineral salts $(\mathrm{Co} 2+)$ are constantly present in food products, mainly of animal origin (EFSA Panel on Additives, 2009). The obtained data suggest that a permissible daily intake of $\mathrm{Co} 2+$ into a human body may be limited up to $1,000 \mu \mathrm{g} /$ day. According to other data, a permissible daily intake dose for $\mathrm{Co} 2+$ is about $600 \mu \mathrm{g} /$ day (EFSA Panel on Additives, 2009). The existing sanitary norms of the Republic of France stipulate the limiting values of the permissible daily consumption of $\mathrm{Co} 2+$ (depending on age), which are 1.6-8 $\mu \mathrm{g} / \mathrm{kg}$ bw / day [10]. Given that normal food intake of cobalt ions is, on average, $0.012 \mathrm{mg}$ day -1 per person, reaching higher values in some populations of India $0.23 \mathrm{mg}$ day -1 and Japan $0.036 \mathrm{mg}$ day -1 . Excessive physiological norms of oral consumption of $\mathrm{Co} 2+$ can cause toxic effects, activating the processes of mutagenesis, carcinogenesis and tissue necrosis through the induction of reactive oxygen species formation and suppressing the work of DNA repair systems [11-13], activation of pro-inflammatory factor products, thyroid dysfunction, increased risk of cardiomyopathy, encephalopathy and congenital birth defects [14-16]. The obtained data from population-based studies confirm that higher levels of cobalt intake into a human body may lead to a decrease in visual acuity [17].

In humans as well as in other mammals the mineral salts of $\mathrm{Co} 2+$ do not participate in the processes of biosynthesis of cobalamins by the intestinal microflora. At the same time we have obtained some data reports indicating that $\mathrm{Co} 2+$ ions coming from food (not included in cobalamins) can cause regulatory effects mediated by the production of physiologically active substances that act as a kind of cation mediators in relation to various tissues and organs. Primarily, these effects are related to hypoxia-inducible 
factor (HIF) [18-21]. Meanwhile, that particular influence of cobalt on a body which is mediated through the hypoxia-inducible factor does not entirely correspond to the generally accepted views on the toxic effects of cobalt substances. Perhaps, therefore, over the past two decades, this line of research has quite clearly transformed into an independent research direction. The presence of its own specific approaches and research methods allows it to productively bring about a range of issues concerning the pathophysiological and regulatory aspects of the $\mathrm{Co} 2+$ influence on a human body. In our opinion, this is the most promising and relevant direction for both fundamental science and practical medicine.

Consequently, the purpose of our data analysis is to provide the current information about the regulatory and pathophysiological effects of $\mathrm{Co} 2+$ in a human body regarding the systemic, tissue and molecular levels after toxic food intake or during accumulation of the cobalt cation in the extracellular body fluid.

Toxic effects of cobalt. In the context of the facts under consideration, information on the pronounced direct toxic effects of cobalt can appear to be rather interesting because it allows to make a clearer distinction between the mechanisms of the regulatory and toxic effects of $\mathrm{Co} 2+$. It should be noted that the origin of the toxic effects and the level of the toxic dose of cobalt cation largely depend on the way how it enters the body: orally, inhaled, or through the skin. According to some authors, the threshold values of its oral intake were identified, the excess of which causes a toxic effect. In particular, for oral administration of $\mathrm{Co} 2+$, the minimum risk threshold is associated with daily ion intake of about $0.01 \mathrm{mg} \mathrm{Co} / \mathrm{kg}$ body weight / day. The review shows that induced $\mathrm{Co} 2+$ cardiomyopathy can be caused by food intake of an ion within 0.04 to 0.14 $\mathrm{mg} \mathrm{Co} / \mathrm{kg} /$ day. There is an opinion on the relevance of studies aimed at substantiating the threshold levels of $\mathrm{Co} 2+$ compounds in a human body since the proportion of anthropogenic factor in the bioavailability of this chemical element for humans has significantly increased. It has been suggested that the threshold values of the systemic toxic effects of $\mathrm{Co} 2+$ may be due to the saturation of the intravascular deposition systems of the cation (plasma proteins and erythrocytes) and an increase in the concentration of free [22].

Hence, not only the levels of food intake of metal ions, but the state, for example, of protein metabolism, can determine the degree of $\mathrm{Co} 2+$ toxicity. Indeed, there are direct evidences that a low protein diet can be considered as an additional risk factor for the development of the toxic effects produced by $\mathrm{Co} 2+$. The results of clinical studies also confirmed the ability of plasma proteins to bind $\mathrm{Co} 2+$ ions, emphasizing the possible role of this mechanism in neurotoxic effects produced by metal cations.

The available data suggest that the direct toxic effects of $\mathrm{Co} 2+$ on humans and animals occur mainly due to the elevation of reactive oxygen species resulting in the activation of lipid peroxidation and proteins, followed by severe destructions of nucleic acids and the suppression of DNA repair systems [23]. It is indicated that the application of antioxidants reduces the toxic effect of cobalt [24]. The authors of the cited review indicate that not only salts, but also metallic cobalt possess genotoxic properties, while cobalt compounds, for example, with tungsten or tungsten carbide, can enhance their genotoxic and carcinogenic properties.

Meanwhile, there is some evidence that direct damage to mitochondria can be considered as another pathogenetic mechanism of polyorganic disorders induced by cobalt salts [25]. According to the authors of the cited publication, the toxic effect of $\mathrm{Co} 2+$ on mitochondria contributes to the development of oxidative stress and damage to mitochondrial DNA regardless of the nuclear DNA 
damage. In vitro studies on murine embryonic stem cells revealed that cobalt dichloride $\mathrm{CoCl} 2$ enhanced the formation of reactive oxygen species, reduced the level of antioxidant defense, promoted the release of cytochrome $\mathrm{C}$ from mitochondria into the cytoplasm and finally activated mitochondrial cell apoptosis [26]. The authors highlighted that toxic effects of cobalt dichloride depended on a dose and a time period during which cells were exposed to a medium containing heavy metal ions. It was reported that cobalt dichloride was able to induce the formation of a superoxide anion in the mitochondria of various human cells [27].

In our opinion, it should be taken into account that the toxic levels of $\mathrm{Co} 2+$ can have a specific effect on the immune system. In particular, studies on human monocytes and neutrophils in vitro have shown that $\mathrm{Co} 2+$ cations activate the Toll-like receptor4 (TLR4) of leukocytes, stimulating cell migration, resulting in increased production of pro-inflammatory cytokines and the formation of foci of infiltrates [28]. On the other hand, the induced by $\mathrm{Co} 2+$ Toll-like receptor-4 is expressed on the human microvascular endothelial cells [29]. So, the cited results go in a good agreement with the previously obtained information about $\mathrm{Co} 2+$-dependent induction of TLR4 in murine peritoneal macrophages is accompanied by the overproduction of pro-inflammatory cytokines and tissue hormones [30].

Nevertheless, the analysis of the toxic properties that a substance might have should be always based on research on its kinetics in a human body. On one hand, a number of organs (myocardium, liver, kidneys) with the ability to accumulate $\mathrm{Co} 2+$ ions have been identified. There is indication of a change in metabolic processes in the liver and kidneys of rats exposed to prolonged exposure to cobalt dichloride in a dose equal to $12.5 \mathrm{mg}$ cobalt $\mathrm{kg}-1$ for 7 days [31]. Pathomorphological studies have shown that cobalt dichloride leads to dose-dependent structural disorders in the liver and myocardial tissue [32]. In the context of the previously discussed issues, it is important to emphasize that the tissues characterized by a high intensity of $\mathrm{Ca} 2+$ metabolism can be considered as a target for the toxic effects of $\mathrm{Co} 2+$. Indeed, the results of experimental studies suggest that salts of $\mathrm{Co} 2+$ triggered the necrotic changes in the heart and kidneys [33]. Skeletal musculature can be also considered as a $\mathrm{Co} 2+$ target organ. It has been established that Bcl-2 adenovirus E1B interacting protein-3 (BNIP3) is an important component in muscle tissue, determining $\mathrm{Co} 2+$-induced autophagy via the HIF - BNIP3. In connection with these facts, information about the mechanisms of $\mathrm{Co} 2+$ ion entry into a cell and into its mitochondria can be quite helpful. Divalent metal ion transporter 1 (DMT1) is considered to be the main channel of $\mathrm{Co} 2+$ entry (as well as divalent ions of iron and nickel). However, it is reported that the transport of the histidine aminoacid through the cationic aminoacid transporter Cat 1 can also be involved in the absorption of cobalt cations, whereas the Zhfl transport protein, which is responsible for the metabolism of zinc ions, can detoxify cells from cobalt cations. According to the current references, the further entry of the $\mathrm{Co} 2+$ from the cytoplasm into the mitochondrial matrix is carried out according to the equivalent transport mechanism of $\mathrm{Ca} 2+$ and other bivalent metal ions - the mitochondrial permeable transitional pore mechanism mediated by the mitochondrial potential [34]. In addition, the authors draw attention to the fact that $\mathrm{Co} 2+$ ions alike $\mathrm{Ca} 2+$ ions, can influence the system of mitochondrial translocations.

On the other hand, the results of in vitro studies on the culture of cardiomyocytes made it possible to establish that the toxic properties of cobalt dichloride occurred due to a direct toxic effect on the state of redox processes in mitochondria that triggered the cell apoptosis [35]. Perhaps a feature of the cardiotoxic action of $\mathrm{Co} 2+$ is the disruption 
of the fundamental processes of energy metabolism in mitochondria which are not capable to maintain the adequate contractile functions of cardiomyocytes affecting both systole and diastole [36]. Arguments confirming damage to mitochondria by cobalt $(\mathrm{Co} 2+)$ ions of the tricarboxylic acid cycle [37] are also being discussed. In vitro studies have established that cobalt dichloride stimulates oxidative stress and apoptosis in a dose-dependent manner [38]. The authors showed that $\mathrm{Co} 2+$ ions stimulated the expression of dynamin-related protein 1 (Drp1), which determined the pathogenetic mechanisms of cell death: a decrease in the mitochondrial membrane potential, a decrease in ATP level, the stimulation of the formation of reactive oxygen forms. The mechanisms of cell apoptosis caused by mitochondrial damage and excessive stimulation of oxidative stress are considered to be the universal pathogenetic mechanism of $\mathrm{Co} 2+$ induced damage to the central nervous. It is also impossible to exclude the fact that a synergistic factor determining the nature of the influence of cobalt dichloride on the fundamental metabolic processes (Krebs cycle activity, electron transport rate by cytochromes and mitochondrial DNA transcription activity) in the mitochondria can be considered as a hypoxia-inducible factor [39].

Nowadays attention is drawn to the fact that most authors, discussing the toxic effect of $\mathrm{Co} 2+$ on mitochondria, point to increased production of reactive oxygen species and the induction of apoptosis, as two closely related effects. Meanwhile, there are reports in the literature that such close relationship between oxidative stress and apoptosis is more typical for the pure metallic cobalt [40]. At the same time, the authors of the cited publication provide the data that the path of stimulation of apoptotic signals by $\mathrm{Co} 2+$ ions may not be directly related to the activation of oxidative stress.

Pathophysiological effects of Co2+. An important aspect of the problem under discussion is that cobalt mineral salts, those which are not part of cobalamins, can have their own regulatory effect on the state of metabolic processes in a human body. Cobalt salts $(\mathrm{Co} 2+)$ have been used for a long time as a pharmacological stimulators of hematopoiesis in the treatment of anemias [41, 42]. Further studies have shown that hypoxiainducible factor is the leading mediator that determines the pathway and intensity of the effects of cobalt mineral salts on a human body. The question regarding the feasibility of pharmacological treatment of anemia with cobalt hematopoietic salts was withdrawn from wide practical application in the 70 s of the 20th century. Meanwhile, the possible aspects related to using cobalt mineral salts, mainly in the form of $\mathrm{Co} 2+$ still remain in the field of interests of modern practical medicine and is reflected in a number of modern publications.

According to the modern references the hypoxia-inducible factors are considered to be the main mediators of the regulatory and pathophysiological effects of the $\mathrm{Co} 2+$ salts. An analysis of the possible mechanisms of Co2+-dependent induction of hypoxia-inducible factors allowed to express the opinion that the suppression of the metabolic clearance of HIF-1 $\alpha$ as a result of $\mathrm{Co} 2+$-induced decrease in the enzymatic activity of prolyl hydroxylases was not likely to be associated with the replacement of the $\mathrm{Fe} 2+$ ion with $\mathrm{Co} 2+$ in the enzyme catalytic center $[43,44]$. According to the authors of the cited publications, the more likely mechanism of $\mathrm{Co} 2+-$ dependent stabilization of HIF-1 $\alpha$ is depletion in the presence of $\mathrm{Co} 2+$ ions of intracellular reserves of ascorbic acid, which is crucial for the reduction of $\mathrm{Fe} 3+$ to $\mathrm{Fe} 2+$ in the active center of prolyl hydroxylases. Some data represents the role of $\mathrm{Co} 2+$ in the metabolic clearance of HIF-1 $\alpha$ with the participation of von Hippel-Lindau protein [45], as well as in the stimulation of HIF-1 $\alpha$ translation.

However, by analyzing the effects produced by $\mathrm{Co} 2+$ salts bounded with the stabi- 
lization of HIF-1 $\alpha$, a unique pattern can be revealed that is not observed during review the basic pathogenetic mechanisms of the toxic effects produced by this metal. Firstly, the direct toxic effects of $\mathrm{Co} 2+$ mineral salts are considered as a uniquely negative factor. At the same time, in the case of low levels of $\mathrm{Co} 2+$ intake not exceeding the toxic threshold values, in addition to negative body reactions, we can observe physiological effects which are potentially applicable in practical medicine. For example, in earlier studies it was suggested that cobalt dichloride could serve as a promising adaptogen in the conditions of hypobaric hypoxia [46]. The results of later studies show the promising outcomes of cobalt in vitro application in regenerative medicine in order to: form HIF-1 $\alpha$-dependent $\mathrm{Co} 2+$ induce stem cells of a certain phenotype [47], create conditions that are optimal for implant engraftment [48] and to control osteogenic differentiation [49]. Along with this, promising results on nephroprotective properties of cobalt salts were obtained in in vivo studies $[50,51]$. Considering the previously identified HIF-1 $\alpha$ dependent nephroprotective properties of $\mathrm{Co} 2+$, the use of organometallic cobalt complexes has been proposed, which are able to provide strictly supervised intrarenal level of $\mathrm{Co} 2+$ production in order to inhibit interstitial fibrosis.

Secondly, the ability of $\mathrm{Co} 2+$ ions to stabilize HIF-1 $\alpha$ is considered to be a pleiotropic pathophysiological mechanism of cation influence associated with producing various physiologically active molecules and affecting the mitochondrial function. In regard to this statement, the warnings that cobalt mineral salts are not the mandatory component of human diet and their food consumption should be strictly standardized are absolutely reasonable. Indeed, research results show that even relatively low levels of cobalt dichloride intake can cause vivid changes in metabolic processes in the myocardium and in the renal parenchyma [52]. It was also established that cobalt dichloride even in the low doses not exceeding the toxic threshold, may trigger the tissue fibrosis and necrosis [53].

In earlier publications, there is evidence of demand for biomonitoring of the presence of $\mathrm{Co} 2+$ in human food, emphasizing the versatility of such pathophysiological reactions, such as inflammation, in response to the presence of a cation in the body [54]. Also, it is necessary to point out that the authors of the cited reviews emphasize the role of HIFs proteins in the realization of the pathophysiological effects produced by cobalt. It is possible that a more significant range of pathophysiological reactions to intake of $\mathrm{Co} 2+$ can be related to a number of HIF-1 $\alpha$-dependent regulatory effects of $\mathrm{Co} 2+[55,56]$. In particular, it is indicated that inflammation can be considered as one of the pathogenetic HIF- $1 \alpha$-related effects of hypoxia. There are also grounds to believe that $\mathrm{Co} 2+$ ions stimulate the expression of the cyclooxygenase- 2 protein gene, against the background of a decrease in the enzymatic activity of endothelial NO-synthase complexes [57]. In vitro studies have shown that $\mathrm{Co} 2+$ have the ability to activate the biosynthesis of inducible NO synthase and pro-inflammatory interleukins in macrophages. A number of publications emphasize the universal pathogenetic role played by the Toll-like receptor-4 (TLR4) of leukocytes in body's immune responses to salts of heavy metals such as cobalt and nickel [58]. It is interesting that nanoparticles of metallic cobalt can also stimulate the dose-dependent production of human monocytic IL-1 $\beta$ and TNF- $\alpha$ [59]. The authors of the cited publications also provide facts confirming the role of the pro-inflammatory effect produced by cobalt and its compounds in the pathogenesis of the immunopathologies in muscular and bone tissues. However, there is evidence in the literature that cobalt dichloride can induce immunosuppression by suppressing the action of pro-inflammatory factors [60]. 
Although, as we have already observed, the regulatory effects of the metal may depend on the dose of exposure and some other experimental conditions.

At the same time, it has been shown that cobalt salts in the liver, in subtoxic concentrations, can stimulate the production of a transforming factor beta-pleiotropic cytokine, which determines cell cycle restriction, stimulation of extracellular matrix protein synthesis combined with immunosuppressor effects. The authors of the cited source believe that the dynamics of TGF-beta production reflects the risk of organ fibrosis and can act as the cancerogenic factor. Attention is drawn to the fact that $\mathrm{Co} 2+$-induced fibrosis may be systemic and get triggered by the generation of reactive oxygen species, while the another heavy metal chromium ions $(\mathrm{Cr} 3+)$ do not act this way $[61,62]$.

Discussing HIF-1 $\alpha$-dependent regulatory effects of $\mathrm{Co} 2+$ in our consideration, it is necessary to point out another important area of research due to the ability of the metal to participate in the regulation of gene expression through such mechanisms as covalent chromatin modification and synthesis of small non-coding RNA. This line of research is developing dynamically in the field of testing new diagnostic methods, and is also valuable in developing a fundamentally new way to treat the most lethal cancer cases [63-65].

Epigenetic effects of $\mathbf{C o 2}+$. The earliest publications on this topic contain information that $\mathrm{Co} 2+$ can stimulate the transcription of certain proteins independently of the intracellular endogenous production of reactive oxygen species. Further, directly induced by $\mathrm{Co} 2+\mathrm{HIF}-1 \alpha$-dependent epigenetic mechanisms associated with enzyme DNA methylation and histone acetylation systems were evidenced. In the modern reviews the role of epigenetic mechanisms in the implementation of toxic and carcinogenic effects of heavy metals is widely emphasized [66-69]. The importance of the HIF-1 $\alpha$-dependent epigenetic mechanisms induced by cobalt and other heavy metals is also recognized. It was also shown that stimulation of cobalt dichloride with extracellular matrix deposits, as well as induction of vascular endothelial growth factor and erythropoietin were associated with HIF-1 $\alpha$ [70]. In our opinion, the scientific novelty of the proposed approach consists in the fact that for the first time the pathogenesis of deadly oncological diseases induced by heavy metals was explained and based on epigenetic mechanisms for controlling of gene expression. At the same time, the pathogenesis of these diseases was not considered as a result of direct DNA damage $[71,72]$. The developed approach was based on the carcinogenic effects produced by heavy metals and caused by a specific covalent modification of chromatin that alters gene expression. The sustainability of this approach was confirmed by subsequent research results [73].

The results of in vitro studies on cell culture of multiple myeloma (B-cell malignancy selectively localized in the bone marrow) showed that the presence of cobalt chloride had a significant effect on the levels of HIF- $1 \alpha$ in cells, as well as on the state of expression of the genes identified as transcription factors, cell differentiation markers, protein kinases, cytokines and growth factors, tumor suppressors, and oncogenes $[74,75]$. According to the authors, they managed to isolate a group of genes sensitive to $\mathrm{Co} 2+$ ions. It was also established that cobalt dichloride, through the processes of acetylation of histone proteins, regulates the expression of extracellular-superoxide dismutase [76]. On the other hand, valproic acid, and histone deacetylase inhibitors, has been shown to reduce the pathophysiological effects of HIF-1 $\alpha$ [77].

Along with this, it was shown that HIF$1 \alpha$ can regulate not only the covalent modification of chromatin, but also affect the biosynthesis of small non-coding RNAs capable of determining protein biosynthesis at the 
level of transcription or translation. Indeed, there is evidence in the literature that HIF may influence the metabolic systems of noncoding small RNAs [78]. At the same time, in vitro studies have established a link between the presence of cobalt in a medium, HIFs with proteins, and the expression index of micro RNA cells. There is evidence that HIF-dependent mechanisms, through the micro-RNA system, are involved in the regulation of the expression of pro-inflammatory cytokines. The mechanisms of $\mathrm{Co} 2+$ inflammation induction play an important role in the pathogenesis of cobalt intoxication, however, the role of epigenetic mechanisms that determine the synthesis (including micro RNA) of pro-inflammatory protein factors has not been studied deeply enough.

Conclusions. The relevance of studying the kinetics of heavy non-ferrous metals coming from the industrial objects is determined by significant pollution of the modern ecosystems. Ecotoxicants affect all internal organs at the molecular, cellular, tissue and systemic levels. The toxic effect of the damaging factor depends on its concentration and exposure duration, its combination with the other damaging factors, chronic human diseases and its immunological reactivity.

One of the representatives of heavy nonferrous metals is cobalt, which simultaneously belongs to the group of microelements and therefore is vital for the functioning of living organisms, but at the same time, with its increased intake, it is toxic to a body and even destructive. There are certain concentrations in which cobalt is essential for living organisms. The main biological role of this element is its presence in the molecule of water-soluble vitamin B12 (cyancobalamin), in which its mass fraction is $4 \%$. However, excessive intake of cobalt in a body is geno-, enzyme-and membrane-toxic. The toxicity of cobalt in high concentrations occurs due to its hypoxic action, activation of lipid peroxidation and depletion of antioxidant systems. Cobalt, as an ion with variable valence, se- verely induces lipid peroxidation, promotes the formation of oxidative stress, which disrupts the function of the endothelium, damages biological macromolecules of internal organs: respiratory organs, cardiovascular system, liver and especially kidneys, where xenobiotics are neutralized.

The data from a number of studies indicate a toxic effect produced by cobalt chloride on the kidneys and myocardium, characterized by the development of microangiopathy, fibrotic proliferation, stimulation of apoptosis and even necrosis. The basis of the toxic effect produced by heavy nonferrous metal salts, including cobalt, is the development of oxidative stress that can damage the cell and mitochondrial membranes and cause their structural and functional changes. The blocking of functionally active groups, structural proteins and functioning enzymes plays a significant role in the development of these disorders. Another mechanism of the toxic effect of heavy metals on the body is their ability to replace calcium ions in specific processes.

The toxic effect produced by cobalt has been studied many times and has already been proven, however the mechanisms of the damaging effect produced by cobalt at the molecular and DNA level have not yet been fully studied. Cobalt dichloride ( $\mathrm{CoCl} 2)$ has a similar effect to hypoxia due to expression of HIF-1 $\alpha$ mRNA, which indicates the dependence of the expression process of this mRNA not only according to oxygen level, but also in the presence of iron ions. Cobalt is able to firmly bind with heme than iron. It was also shown that cobalt activates HIF-1 due to depletion of the intracellular content of ascorbic acid, a co-factor for HIF-hydroxylase, which destabilizes and inactivates HIF-1 $\alpha$. Hypoxia is known to be a typical pathological process that accompanies and determines the development of many pathological conditions. It leads to functional, and then structural changes in organs and tissues as a result of a decrease in the intracellular 
concentration of oxygen. This also applies to hypoxia of tumor cells (intratumoral hypoxia). Thus, many cancers include areas of hypoxia. Intratumoral hypoxia significantly worsens the forecast of the disease, since angiogenesis in the tumor tissues is very intense. This, apparently, is one of the reasons for the rapid growth of malignant tumors and can explain cancerogenic cobalt effect. In addition, enhanced angiogenesis in the tumor contributes to the metastasis of its cells, which ultimately increases mortality among such patients. The principal mechanism with which cancer cells adapt to hypoxia is activation of the HIF-1 factor. The elucidation of the pathogenetic role played by the HIF-1 $\alpha$ factor opens up new possibilities not only in the correction of hypoxia, but also in the treatment of malignant tumors.

As illustrated, the influence of cobalt ions on a body should be researched deeply, as well as interactions between cobalt and other ions and aminoacids occurring in body fluid. Perhaps these interactions can also have some specific and significant beneficial effects.

Funding. The research was not granted any sponsor support.

Conflict of interests. The authors state there is no any conflict of interests.

\section{References}

1. Hokin B., Adams M., Ashton J., Louie H. Comparison of the dietary cobalt intake in three different Australian diets. Asia. Pac. J. Clin. Nutr., 2004, vol. 13, no. 3, pp. 289-291.

2. Gál J., Hursthouse A., Tatner P., Stewart F., Welton R. Cobalt and secondary poisoning in the terrestrial food chain: Data review and research gaps to support risk assessment. Environment International, 2008, no. 34, pp. 821-838. DOI: 10.1016/j.envint.2007.10.006

3. Scientific Opinion on the use of cobalt compounds as additives in animal nutrition. EFSA Panel on Additives and Products or Substances used in Animal Feed (FEEDAP). EFSA Journal, 2009, vol. 7, no. 12: 1383, 45 p. DOI: $10.2903 /$ j.efsa.2009.1383

4. Tvermoes B.E., Paustenbach D.J., Kerger B.D., Finley B.L., Unice K.M. Review of cobalt toxicokinetics following oral dosing: Implications for health risk assessments and metal-on-metal hip implant patients. Crit. Rev. Toxicol., 2015, vol. 45, no. 5, pp. 367-387. DOI: $10.3109 / 10408444.2014 .985818$

5. Tvermoes B.E., Unice K.M., Paustenbach D.J., Finley B.L., Otani J.M., Galbraith D.A. Effects and blood concentrations of cobalt after ingestion of $1 \mathrm{mg} / \mathrm{d}$ by human volunteers for $90 \mathrm{~d}$. Am. J. Clin. Nutr., 2014, no. 99, pp. 632-646. DOI: 10.3945/ajen.113.071449

6. Unice K.M., Monnot A.D., Gaffney S.H., Tvermoes B.E., Thuett K.A., Paustenbach D.J., Finley B.L. Inorganic cobalt supplementation: Prediction of cobalt levels in whole blood and urine using a biokinetic model. Food and Chemical Toxicology, 2012, vol. 50, no. 7, pp. 2456-2461. DOI: 10.1016/j.fct.2012.04.009

7. Wei B., Yu J., Wang J., Li H., Yang L., Kong C. Trace Metals in the Urine and Hair of a Population in an Endemic Arsenism Area. Biol. Trace. Elem. Res., 2018, vol. 182, no. 2, pp. 209-216. DOI: 10.1007/s12011-017-1108-x

8. Simonsen L.O., Harbak H., Bennekou P. Cobalt metabolism and toxicology - a brief update. Sci. Total. Environ., 2012, vol. 432, pp. 210-215. DOI: 10.1016/j.scitotenv.2012.06.009

9. Ryuko S., Ma Y., Ma N., Sakaue M., Kuno T. Genome-wide screen reveals novel mechanisms for regulating cobalt uptake and detoxification in fission yeast. Mol. Genet. Genomics, 2012, vol. 287, no. 8, pp. 651-662. DOI: 10.1007/s00438-012-0705-9

10. Leyssens L., Vinck B., Van Der Straeten C., Wuyts F., Maes L. Cobalt toxicity in humans a review of the potential sources and systemic health effects. Toxicology, 2017, no. 387, pp. 43-56. DOI: $10.1016 /$ j.tox.2017.05.015

11. De Boeck M., Kirsch-Volders M., Lison D. Cobalt and antimony: genotoxicity and carcinogenicity. Mutat. Res., 2003, vol. 533, no. 1, 2, pp. 135-152. DOI: 10.1016/j.mrfmmm.2003.07.012 
12. Paustenbach D.J., Tvermoes B.E., Unice K.M., Finley B.L., Kerger B.D. A review of the health hazards posed by cobalt. Crit. Rev. Toxicol., 2013, vol. 43, no. 4, pp. 316-362. DOI: 10.3109/10408444.2013.779633

13. Liang Y., Zhen X., Wang K., Ma J. Folic acid attenuates cobalt chloride-induced PGE2 production in HUVECs via the NO/HIF-1alpha/COX-2 pathway. Biochem. Biophys. Res. Commun., 2017, vol. 490, no. 2, pp. 567-573. DOI: 10.1016/j.bbrc.2017.06.079

14. Yorita C.K.L. Metals in blood and urine, and thyroid function among adults in the United States 2007-2008. Int J. Hyg. Environ. Health, 2013, vol. 216, no. 6, pp. 624-632. DOI: 10.1016/j.ijheh.2012.08.005

15. Catalani S., Rizzetti M.C., Padovani A., Apostoli P. Neurotoxicity of cobalt. Hum. Exp. Toxicol., 2012, vol. 31, no. 5, pp. 421-437. DOI: 10.1177/0960327111414280

16. Dai Y., Li W., Zhong M., Chen J., Liu Y., Cheng Q., Li T. Preconditioning and posttreatment with cobalt chloride in rat model of perinatal hypoxic-ischemic encephalopathy. Brain Dev., 2014, vol. 36, no. 3, pp. 228-240. DOI: 10.1016/j.braindev.2013.04.007

17. Mendy A., Gasana J., Vieira E.R. Urinary heavy metals and associated medical conditions in the US adult population. Int. J. Environ. Health Res., 2012, vol. 22, no. 2, pp. 105-118. DOI: 10.1080/09603123.2011.605877

18. Yuan Y., Hilliard G., Ferguson T., Millhorn D.E. Cobalt inhibits the interaction between hypoxia-inducible factor-alpha and von Hippel-Lindau protein by direct binding to hypoxiainducible factor-alpha. J. Biol. Chem., 2003, vol. 278, no. 18, pp. 15911-15916. DOI: 10.74/jbc.M300463200

19. Maxwell P., Salnikow K. HIF-1: an oxygen and metal responsive transcription factor. Cancer Biol. Ther., 2004, vol. 3, no. 1, pp. 29-35. DOI: 10.4161/cbt.3.1.547

20. Jelkmann W. The Disparate Roles of Cobalt in Erythropoiesis, and Doping Relevance. Open Journal of Hematology, 2012, vol. 3, no. 1, pp. 3-6. DOI: 10.13055/ojhmt_3_1_6.121211

21. Muñoz-Sánchez J., Chánez-Cárdenas M.E. The use of cobalt chloride as a chemical hypoxia model. J. Appl. Toxicol., 2018, vol. 39, no. 4, pp. 1-15. DOI: 10.1002/jat.3749

22. Catalani S., Leone R., Rizzetti M.C., Padovani A., Apostoli P. The Role of Albumin in Human Toxicology of Cobalt: Contribution from a Clinical Case. ISRN Hematology, 2011, vol. 2011, 6 p. DOI: $10.5402 / 2011 / 690620$

23. Jomova K., Valko M. Advances in metal-induced oxidative stress and human disease. Toxicology, 2011, vol. 283, no. 2, 3, pp. 65-87. DOI: 10.1016/j.tox.2011.03.001

24. Zadnipryany I.V., Tretiakova O.S., Sataieva T.P., Zukow W. Experimental review of cobalt induced cardiomyopathy. Russian Open Medical Journal, 2017, vol. 6, no. 1, pp. 1-4. DOI: 10.15275/rusomj.2017.0103

25. Wang G., Hazra T.K., Mitra S., Lee H.M., Englander E.W. Mitochondrial DNA damage and a hypoxic response are induced by $\mathrm{CoCl}(2)$ in rat neuronal PC12 cells. Nucleic. Acids. Res., 2000, vol. 28 , no. 10, pp. 2135-2140. DOI: $10.1093 / \mathrm{nar} / 28.10 .2135$

26. Lee J.-H., Choi S.-H., Baek M.-W., Kim M.-H., Kim H.-J., Kim S.-H., Oh S.-J., Park H.-J. [et al.]. $\mathrm{CoCl} 2$ induces apoptosis through the mitochondria- and death receptor-mediated pathway in the mouse embryonic stem cells. Mol. Cell. Biochem., 2013, vol. 379, pp. 133-140. DOI: 10.1007/s11010-013-1635-5

27. K. Chamaon, P. Schönfeld, F. Awiszus, J. Bertrand, C.H. Lohmann. Ionic cobalt but not metal particles induces ROS generation in immune cells in vitro. J. Biomed. Mater. Res. B. Appl. Biomater., 2019, vol. 107, no. 4, pp. 1246-1253. DOI: 10.1002/jbm.b.34217

28. Lawrence H., Deeha D.J., Holland J.P., Anjum S.A., Mawdesley A.E., Kirby J.A., TysonCappera A.J. Cobalt ions recruit inflammatory cells in vitro through human Toll-like receptor-4. Biochem. Biophys. Rep., 2016, vol. 7, pp. 374-378. DOI: 10.1016/j.bbrep.2016.07.003

29. S.A. Anjum, H. Lawrence, J.P. Holland, J.A. Kirby, D.J. Deehan, A.J. Tyson Effect of cobaltmediated Toll-like receptor 4 activation on inflammatory responses in endothelial cells. Oncotarget, 2016, vol. 7, no. 47, pp. 76471-76478. DOI: 10.18632/oncotarget. 13260

30. Shweta, Mishra K.P., Chanda S., Singh S.B., Ganju L. A comparative immunological analysis of $\mathrm{CoCl} 2$ treated cells with in vitro hypoxic exposure. Biometals, 2015, vol. 28, no. 1, pp. 175-185. 
DOI: 10.1007/s10534-014-9813-9 31. Shrivastava K., Bansal A., Singh B., Sairam M., Ilavazhagan G. Sub-chronic oral toxicity study in Sprague-Dawley rats with hypoxia mimetic cobalt chloride towards the development of promising neutraceutical for oxygen deprivation. Exp. Toxicol. Pathol., 2010, vol. 62, no. 5, pp. 489-496. DOI: 10.1016/j.etp.2009.06.012

32. Liu Y., Xu H., Liu F., Tao R., Yin J. Effects of serum cobalt ion concentration on the liver, kidney and heart in mice. Orthopaedic Surgery, 2010, vol. 2, no. 2, pp. 134-140. DOI: 10.1111/j.17577861.2010.00076.x

33. Akinrinde A.S., Oyagbemi A.A., Omobowale T.O., Asenuga E.R., Ajibade T.O. Alterations in blood pressure, antioxidant status and caspase 8 expression in cobalt chloride-induced cardiorenal dysfunction are reversed by Ocimum gratissimum and gallic acid in Wistar rats. J. Trace. Elem. Med. Biol., 2016, no. 36, pp. 27-37. DOI: 10.1016/j.jtemb.2016.03.015

34. Feng W., Zhang Y., Deng H., Li S.J. Interaction of divalent metal ions with human translocase of inner membrane of mitochondria TIM23. Biochem. Biophys. Res. Commun., 2016, vol. 475, no. 1, pp. 76-80. DOI: 10.1016/j.bbrc.2016.05.039

35. Niu N., Li Z., Zhu M., Sun H., Yang J., Xu S., Zhao W., Song R. Effects of nuclear respiratory factor-1 on apoptosis and mitochondrial dysfunction induced by cobalt chloride in H9C2 cells. Molecular medicine reports, 2019, vol. 19, no. 3, pp. 2153-2163. DOI: 10.3892/mmr.2019.9839

36. Hantson P. Mechanisms of toxic cardiomyopathy. Clin. Toxicol., 2019, vol. 57, no. 1, pp. 1-9. DOI: $10.1080 / 15563650.2018 .1497172$

37. Kurhaluk N., Lukash O., Nosar V., Portnychenko A.G., Portnychenko V., WszedybylWinklewska M., Winklewski P.J. Liver mitochondrial respiratory plasticity and oxygen uptake evoked by cobalt chloride in rats with low and high resistance to extreme hypobaric hypoxia. Can. J. Physiol. Pharmacol., 2019, vol. 97, no. 5, pp. 392-399. DOI: 10.1139/cjpp-2018-0642

38. He Y., Gan X., Zhang L., Liu B., Zhu Z., Li T., Zhu J., Chen J., Yu H. CoCl2 induces apoptosis via a ROS-dependent pathway and Drp1-mediated mitochondria fission in periodontal ligament stem cells. Am. J. Physiol. Cell. Physiol., 2018, vol. 315, no. 3, pp. C389-C397. DOI: 10.1152/ajpcell.00248.2017

39. Saxena S., Shukla D., Bansal A. Augmentation of aerobic respiration and mitochondrial biogenesis in skeletal muscle by hypoxia preconditioning with cobalt chloride. Toxicol. Appl. Pharmacol., 2012, vol. 264, no. 3, pp. 324-334. DOI: 10.1016/j.taap.2012.08.033

40. Liu Y., Hong H., Lu X., Wang W., Liu F., Yang H.L. L-Ascorbic Acid Protected Against Extrinsic and Intrinsic Apoptosis Induced by Cobalt Nanoparticles Through ROS Attenuation. Biol. Trace. Elem. Res., 2017, vol. 175, no. 2, pp. 428-439. DOI: 10.1007/s12011-016-0789-x

41. Ebert B., Jelkmann W. Intolerability of cobalt salt as erythropoietic agent. Drug. Test. Anal., 2014, vol. 6, no. 3, pp. 185-189. DOI: 10.1002/dta.1528

42. Hoffmeister T., Schwenke D., Wachsmuth N., Krug O., Thevis M., Byrnes W.C., Schmidt W.F.J. Erythropoietic effects of low-dose cobalt application. Drug. Test. Anal., 2019, vol. 11, no. 2, pp. 200-207. DOI: $10.1002 / \mathrm{dta} .2478$

43. Karaczyn A., Ivanov S., Reynolds M., Zhitkovich A., Kasprzak K.S., Salnikow K. Ascorbate depletion mediates up-regulation of hypoxia-associated proteins by cell density and nickel. J. Cell. Biochem., 2006, vol. 97, no. 5, pp. 1025-1035. DOI: 10.1002/jcb.20705

44. Kaczmarek M., Cachau R.E., Topol I.A., Kasprzak K.S., Ghio A., Salnikow K. Metal ionsstimulated iron oxidation in hydroxylases facilitates stabilization of HIF-1 alpha protein. Toxicol. Sci., 2009, vol. 107, no. 2, pp. 394-403. DOI: 10.1093/toxsci/kfn251

45. Yuan Y., Hilliard G., Ferguson T., Millhorn D.E. Cobalt inhibits the interaction between hypoxia-inducible factor-alpha and von Hippel-Lindau protein by direct binding to hypoxiainducible factor-alpha. J. Biol. Chem., 2003, vol. 278, no. 18, pp. 15911-15916. DOI: 10.74/jbc.M300463200

46. Shrivastava K., Ram M.S., Bansal A., Singh S.S., Ilavazhagan G. Cobalt supplementation promotes hypoxic tolerance and facilitates acclimatization to hypobaric hypoxia in rat brain. High. Alt. Med. Biol., 2008, vol. 9, no. 1, pp. 63-75. DOI: 10.1089/ham.2008.1046 
47. Jeon E.S., Shin J.H., Hwang S.J., Moon G.J., Bang O.Y., Kim H.H. Cobalt chloride induces neuronal differentiation of human mesenchymal stem cells through upregulation of microRNA-124a. Biochem. Biophys. Res. Commun., 2014, vol. 444, no. 4, pp. 581-587. DOI: 10.1016/j.bbrc.2014.01.114

48. Chai Y.C., Mendes L.F., Van Gastel N., Carmeliet G., Luyten F.P. Fine-tuning proangiogenic effects of cobalt for simultaneous enhancement of vascular endothelial growth factor secretion and implant neovascularization. Acta Biomater., 2018, no. 72, pp. 447-460. DOI: 10.1016/j.actbio.2018.03.048

49. Chen Y., Zhao Q., Yang X., Yu X., Yu D., Zhao W. Effects of cobalt chloride on the stem cell marker expression and osteogenic differentiation of stem cells from human exfoliated deciduous teeth. Cell. Stress. Chaperones., 2019, vol. 24, no. 3, pp. 527-538. DOI: 10.1007/s12192-019-00981-5

50. Matsumoto M., Makino Y., Tanaka T., Tanaka H., Ishizaka N., Noiri E., Fujita T., Nangaku M. Induction of Renoprotective Gene Expression by Cobalt Ameliorates Ischemic Injury of the Kidney in Rats. J. Am. Soc. Nephrol., 2003, no. 14, pp. 1825-1832.

51. Tanaka T., Kojima I., Ohse T., Ingelfinger J.R., Adler S., Fujita T., Nangaku M. Cobalt promotes angiogenesis via hypoxia-inducible factor and protects tubulointerstitium in the remnant kidney model. Laboratory Investigation, 2005, no. 85, pp. 1292-1307. DOI: 10.1038/labinvest.3700328

52. Oyagbemi A.A., Omobowale T.O., Awoyomi O.V., Ajibade T.O., Falayi O.O., Ogunpolu B.S., Okotie U.J., Asenuga E.R. [et al.]. Cobalt chloride toxicity elicited hypertension and cardiac complication via induction of oxidative stress and upregulation of COX-2/Bax signaling pathway. Hum. Exp. Toxicol., 2019, vol. 38, no. 5, pp. 519-532. DOI: 10.1177/0960327118812158

53. Kong D., Zhang F., Shao J., Wu L., Zhang X., Chen L., Lu Y., Zheng S. Curcumin inhibits cobalt chloride-induced epithelial-to-mesenchymal transition associated with interference with TGF$\beta /$ Smad signaling in hepatocytes. Lab. Invest., 2015, vol. 95, no. 11, pp. 1234-1245. DOI: 10.1038/labinvest.2015.107

54. Czarnek K., Terpiłowska S., Siwicki A.K. Selected aspects of the action of cobalt ions in the human body. Cent. Eur. J. Immunol., 2015, vol. 40, no. 2, pp. 236-242. DOI: 10.5114/ceji.2015.52837

55. Nagasawa H. Pathophysiological response to hypoxia - from the molecular mechanisms of malady to drug discovery: drug discovery for targeting the tumor microenvironment. J. Pharmacol. Sci., 2011, vol. 115, no. 4, pp. 446-452.

56. Eskandani M., Vandghanooni S., Barar J., Nazemiyeh H., Omidi Y. Cell physiology regulation by hypoxia inducible factor-1: Targeting oxygen-related nanomachineries of hypoxic cells. Int J. Biol. Macromol., 2017, no. 99, pp. 46-62. DOI: 10.1016/j.ijbiomac.2016.10.113

57. Liang Y., Zhen X., Wang K., Ma J. Folic acid attenuates cobalt chloride-induced PGE2 production in HUVECs via the NO/HIF-1alpha/COX-2 pathway. Biochem. Biophys. Res. Commun., 2017, vol. 490, no. 2, pp. 567-573. DOI: 10.1016/j.bbrc.2017.06.079

58. Schmidt M., Raghavan B., Müller V., Vogl T., Fejer G., Tchaptchet S., Keck S., Kalis C. [et al.]. Crucial role for human Toll-like receptor 4 in the development of contact allergy to nickel. Nat. Immunol., 2010, vol. 11, no. 9, pp. 814-819. DOI: 10.1038/ni.1919

59. Samelko L., Landgraeber S., McAllister K., Jacobs J., Hallab N.J. Cobalt Alloy Implant Debris Induces Inflammation and Bone Loss Primarily through Danger Signaling, Not TLR4 Activation: Implications for DAMP-ening Implant Related Inflammation. PLOS ONE, 2016, vol. 11, no. 7, pp. e0160141. DOI: 10.1371/journal.pone.0160141

60. Kwak J., Choi S.J., Oh W., Yang Y.S., Jeon H.B., Jeon E.S. Cobalt Chloride Enhances the Anti-Inflammatory Potency of Human Umbilical Cord Blood-Derived Mesenchymal Stem Cells through the ERK-HIF-1 $\alpha$-MicroRNA-146a-Mediated Signaling Pathway. Stem. Cells International, 2018, vol. 2018, 12 p. DOI: 10.1155/2018/4978763

61. Xu J., Nyga A., Li W., Zhang X., Gavara N., Knight M.M., Shelton J.C. Cobalt ions stimulate a fibrotic response through matrix remodelling, fibroblast contraction and release of pro-fibrotic signals from macrophages. European Cells and Materials, 2018, no. 36, pp. 142-155. DOI: 10.22203/eCM.v036a11 
62. Ratha S., Dasa L., Kokatea S., Ghosha N., Dixita P., Routb N., Singhc S.P., Chattopadhyaya S. [et al.]. Inhibition of histone/lysine acetyltransferase activity kills CoCl2-treated and hypoxia-exposed gastric cancer cells and reduces their invasiveness. Int J. Biochem. Cell. Biol., 2017, no. 82, pp. 28-40. DOI: 10.1016/j.biocel.2016.11.014

63. Li C.-L., Xu Z.-B., Fan X.-L., Chen H.-X., Yu Q.-N., Fang S.-B., Wang S.-Y., Lin Y.-D., Fu Q.-L. MicroRNA-21 Mediates the Protective Effects of Mesenchymal Stem Cells Derived from iPSCs to Human Bronchial Epithelial Cell Injury Under Hypoxia. Cell. Transplantation., 2018, vol. 27, no. 3, pp. 571-583. DOI: 10.1177/0963689718767159

64. Permenter M.G., Dennis W.E., Sutto T.E., Jackson D.A., Lewis J.A. [et al.]. Exposure to Cobalt Causes Transcriptomic and Proteomic Changes in Two Rat Liver Derived Cell Lines. PLoS ONE, 2013, vol. 8, no. 12, pp. e83751. DOI: 10.1371/journal.pone.0083751

65. Salnikow K., Zhitkovich A. Genetic and Epigenetic Mechanisms in Metal Carcinogenesis and Cocarcinogenesis: Nickel, Arsenic and Chromium. Chem. Res. Toxicol., 2008, vol. 21, no. 1, pp. $28-44$. DOI: $10.1021 /$ tx700198a

66. Salnikow K., Aprelikova O., Ivanov S., Tackett S., Kaczmarek M., Karaczyn A., Yee H., Kasprzak K.S., Niederhuber J. Regulation of hypoxia-inducible genes by ETS1 transcription factor. Carcinogenesis, 2008, vol. 29, no. 8, pp. 1493-1499. DOI: 10.1093/carcin/bgn088

67. Chervona Y., Costa M. The control of histone methylation and gene expression by oxidative stress, hypoxia and metals. Free Radic. Biol. Med., 2012, vol. 53, no. 5, pp. 1041-1047. DOI: 10.1016/j.freeradbiomed.2012.07.020

68. Brocato J., Costa M. Basic Mechanics of DNA Methylation and the Unique Landscape of the DNA Methylome in Metal-Induced Carcinogenesis. Crit. Rev. Toxicol., 2013, vol. 43, no. 6, pp. 493-514. DOI: 10.3109/10408444.2013.794769

69. Bae S., Jeong H.-J., Cha H.J., Kim K., Choi Y.M., An I.-S., Koh H.J., Lim D.J. [et al.]. The hypoxia-mimetic agent cobalt chloride induces cell cycle arrest and alters gene expression in U266 multiple myeloma cells. International journal of molecular medicine, 2012, no. 30, pp. 1180-1186. DOI: $10.3892 /$ ijmm.2012.1115

70. Hattori S., Kamiya T., Hara H., Ninomiya M., Koketsu M., Adach T. CoCl2 Decreases EC-SOD Expression through Histone Deacetylation in COS7 Cells. Biol. Pharm. Bull., 2016, vol. 39, no. 12, pp. 2036-2041. DOI: 10.1248/bpb.b16-00551

71. Chen R., Jiang T., She Y., Xu J., Li C., Zhou S., Shen H., Shi H., Liu S. Effects of Cobalt Chloride, a Hypoxia-Mimetic Agent, on Autophagy and Atrophy in Skeletal C2C12 Myotubes. Biomed. Res. Int., 2017, no. 7097580. DOI: 10.1155/2017/7097580

72. Tan L., Lai X., Zhang M., Zeng T., Liu Y., Deng X., Qiu M., Li J. [et al.]. A stimuli-responsive drug release nanoplatform for kidney-specific anti-fibrosis treatment. Biomater. Sci., 2019, vol. 7, no. 4, pp. 1554-1564. DOI: $10.1039 / \mathrm{c} 8 \mathrm{bm} 01297 \mathrm{k}$

73. Stenger C., Naves T., Verdier M., Ratinaud M.H. The cell death response to the ROS inducer, cobalt chloride, in neuroblastoma cell lines according to p53 status. Int J. Oncol., 2011, vol. 39, no. 3, pp. 601-609. DOI: 10.3892/ijo.2011.1083

74. Chimeh U., Zimmerman M.A., Gilyazova N., Li P.A. B355252, A Novel Small Molecule, Confers Neuroprotection Against Cobalt Chloride Toxicity In Mouse Hippocampal Cells Through Altering Mitochondrial Dynamics And Limiting Autophagy Induction. Int J. Med. Sci., 2018, vol. 15, no. 12, pp. 1384-1396. DOI: 10.7150/ijms.24702

75. Kumanto M., Paukkeri E.-L., Nieminen R., Moilanen E. Cobalt (II) Chloride Modifies the Phenotype of Macrophage Activation. Basic \& Clinical Pharmacology \& Toxicology, 2017, no. 121, pp. 98-105. DOI: 10.1111/bcpt.12773

76. Luo H.-M., Du M.-H., Lin Z.-L., Zhang L., Ma L. [et al.]. Valproic Acid Treatment Inhibits Hypoxia-Inducible Factor $1 \alpha$ Accumulation and Protects against Burn-Induced Gut Barrier Dysfunction in a Rodent Model. PLoS ONE, 2013, vol. 8, no. 10, pp. e77523. DOI: 10.1371/journal.pone.0077523

77. Kim Y.J., Park S.J., Kim N.R., Chin H.S. Effects of Histone Deacetylase Inhibitor (Valproic Acid) on the Expression of Hypoxia-inducibleFactor-1 Alpha in Human Retinal Müller Cells. Korean J. Ophthalmol., 2017, vol. 31, no. 1, pp. 80-85. DOI: 10.3341/kjo.2017.31.1.80 
78. Ho J.J., Metcalf J.L., Yan M.S., Turgeon P.J., Wang J.J., Chalsev M., PetruzzielloPellegrini T.N., Tsui A.K. [et al.]. Functional importance of Dicer protein in the adaptive cellular response to hypoxia. J. Biol. Chem., 2012, vol. 287, no. 34, pp. 29003-29020. DOI: 10.1074/jbc.M112.373365

Dolomatov S.I., Sataeva T.P., Zukow W. Modern aspects of regulatory, pathophysiological and toxic effects of cobalt ions during oral intake in the human body. Health Risk Analysis, 2019, no. 3, pp. 161-174. DOI: 10.21668/health.risk/2019.3.19.eng

Received: 21.05 .2019

Accepted: 26.07.2019

Published: 30.09.2019 


\section{NEW LEGAL, REGULATORY AND METHODOLOGICAL DOCUMENTS ISSUED IN THE RF IN THE SPHERE OF HEALTH RISK ANALYSIS}

June 10 - September 13, 2019

The Decision by the Eurasian Economic Commission (EEC) Council dated June 18, 2019 No. 102 "On making alterations into the Decision by the EEC Council dated June 30, 2017 No. 80"

State registration certificates issued for products can now be electronic. Besides, there have been several alterations: the document contains a unified form of a state registration certificate for a product (the latest edition); amendments have been made into the Rules for issuing state registration certificates for products; the Procedure for keeping a unified register of state registration certificates for products has been adjusted.

The Decision by the Eurasian Economic Commission (EEC) Council dated July 09, 2019 No. 112 "On the Procedure for putting into effect amendments into the Customs Union Technical Regulations "On safety of perfume and cosmetic products" (CU TR 009/2011)"

The document specifies terms of validity for documents certifying that a perfume or cosmetic product conforms to the requirements fixed in the Customs Union Technical Regulations "On safety of perfume and cosmetic products".

It is stated that all the documents that certify conformity of perfume and cosmetic products to the obligatory requirements fixed by the Customs Union Technical Regulations "On safety of perfume and cosmetic products (CU TR 009/2011) that have been issued until May 05, 2020 are valid till the term of their validity expires. All the state registration certificates for perfume and cosmetics products that certify conformity of those products to the obligatory requirements fixed by the abovementioned Technical Regulations and that have been issued prior to the above mentioned date remain valid till May 05, 2023 inclusively regardless of any changes fixed by the given Decision that may concern them.

The Decision by the Eurasian Economic Commission (EEC) Council dated July 16, 2019 No. 119 "On making alterations into the
Decision by the EEC Council dated January 26, 2016 No. 11"

The document specifies peculiarities related to implementation of the Customs Union Technical Regulations "On safety of milk and milk products" in Kyrgyzstan. It is stated that documents on assessing conformity of milk products to the obligatory requirements fixed in Kyrgyzstan legislation that were issued or approved before August 12, 2017 are valid till their validity expires but not longer than August 12, 2022. Till August 12, 2022 it is allowed to produce and distribute milk products according to the requirements fixed by Kyrgyzstan legislation provided that there are documents on their conformity assessment. It is not allowed to mark such products with a unified mark certifying that their distribution is permitted on the markets of the EAEU member states.

The Recommendation by the EEC Council dated July 23, 2019 No. 22 "On interaction between state control (surveillance) authorities responsible for providing adherence to requirements fixed in the EAEU technical regulations and customs authorities of the EAEU member states aimed at preventing manufacture and distribution of products that don't conform to requirements fixed by the EAEU technical regulations"

The document specifies a procedure for interaction between authorized bodies in the EAEU member states responsible for providing adherence to requirements fixed in technical regulations. Recommendations include operational procedures for state control (surveillance) authorities and customs authorities should any products not conforming to such requirement be revealed. It is recommended to apply EEC information resources when interaction between state control (surveillance) authorities and customs authorities of the EAEU member states takes place.

The Decision by the Eurasian Economic Commission (EEC) Council dated August 06, 2019 No. 132 "On making alterations into the list of goods for which unified sanitary requirements 
are fixed (according to EAEU CN FEA codes), contained in Section 1, Chapter II of the Unified Sanitary-epidemiologic and hygienic requirements to products (goods) that are subject to sanitary-epidemiologic surveillance (control)"

Alterations have been made into the list of goods for which unified sanitary requirements are fixed concerning setting up permissible contents of glycidyl ethers that are parts of fat acids. Some additions have been made, in particular, to sections classifying vegetable oils that are consumed by people as food products and are applied as food raw materials, adapted milk mixtures (dried, liquid, made from fresh and sour milk), and products based on partially hydrolyzed proteins, specific products for dietetic therapy for children etc.

The Decision by the Eurasian Economic Commission (EEC) Council dated August 06, 2019 No. 134 "On implementing amendments into the Customs Union technical Regulations "On safety of individual protection means" (CU TR 019/2011)"

It is fixed that documents certifying conformity of individual protection means to the obligatory requirements fixed in the CU TR "On safety of individual protection means" (CU TR 019/2011 issued on December 9, 2011 No. 878) issued or approved prior to May 28, 2019 No.55 are valid till the term of their validity expires. It is allowed to distribute products that are subject to technical regulations on the EAEU customs territory provided that their conformity is certified by the above-mentioned documents prior to expiration of their validity. Such products can be distributed only till expiration of their service life.

The Federal Law issued on July 26, 2019 No. 195-FZ "On performing an experiment on quoting emissions of contaminants and making amendments into certain legislative acts of the Russian Federation concerning reduction of ambient air pollution"

From January 1, 2020 till December 31, 2024 an experiment is to be performed in 12 cities in the Russian Federation (Bratsk, Krasnoyarsk, Lipetsk, Magnitogorsk, Mednogorsk, Nizhniy Tagil, Novokuznetsk, Norilsk, Omsk, Chelyabinsk, Cherepovets, and Chita); it will focus on quoting emissions of contaminants into ambient air. The top priority is to reduce ambient air pollution in cities. Quoting will be performed basing on aggregate calculations of emission dispersion. A list of objects that are subject to quoting will include objects that make ambient air quality deviate from hygienic standards. Such lists should be drawn up by Rosprirodnadzor with the help from Rospotrebnadzor and authorized bodies in RF regions.

A set of activities will be approved for each territory; such activities will be aimed at reducing emissions of contaminants and there should be fixed targets that are to be achieved by their implementation. It is also planned to create a federal information system for monitoring over ambient air quality in the above mentioned 12 cities. Public information contained in this system will be freely available to anybody.

The RF President Order issued on June 06, 2019 No. 254 "On the Strategy for public healthcare development in the Russian Federation up to 2025"

The document fixes priorities in development of public healthcare in the country. They including stimulating Russian cities to pursue healthy lifestyle; working out new medical technologies and their implementation into public healthcare; enlarging a list of preventive vaccinations; developing the system of medical education and staff provision for public healthcare; streamlining operations of the unified state information system in public healthcare; achieving better provision with medications for citizens as well as improving pricing for medications; streamlining control and surveillance activities in public healthcare and providing sanitaryepidemiologic welfare of the population via riskoriented approach being implemented.

Information by the RF Presidential Council on civil society development and human rights dated June 11, 2019. "The RF Ministry "The Ministry of Natural Resources and the Environment of the Russian Federation and Rospotrebnadzor have submitted their proposals on wastes reduction"

The RF Ministry of Natural Resources and the Environment and Rospotrebnadzor support the incentive to prohibit sales of disposable products made of plastic as it will help to reduce negative impacts exerted by economic activities on the environment; they suggest excluding throwaway dishes and plastic bags out of consumption.

Rospotrebnadzor believes it is important to fix the following in the country legislation: stage-bystage decrease (up to complete prohibition) in production of disposable packets used in retail trade; stimulating production and application of reusable package and polymer materials that are able to self- 
destruct under certain conditions (for example, in compost, under exposure to ultra-violet rays, temperature etc.); stimulating re-use of package; obligatory certification of a sign "biologically degradable" or "ecologically safe disposal"; fixing obligatory standards for multiple use of specific package.

Rospotrebnadzor believes it is necessary to develop legislative acts that prohibit dumping and elimination of food products that are esculent as well as to provide regulatory support for use of food wastes and unclaimed food products (wastes) as biological energy sources.

The RF Government Order issued on July 13, 2019 No. 1533-r "On making amendments into the RF Government Order issued on April 28, 2018 No. 792-r"

Certain milk products have been included into lists of products that are subject to being marked with identification means. The lists now include products with the following codes from the All-Russian Products Classifier as per Types of Economic Activities (OKPD 2): 10.51.11, 10.51.12, 10.51.21, 10.51.22, $10.51 .30,10.51 .40,10.51 .51,10.51 .52,10.51 .55$, $10.51 .56,10.52 .10$. A date by which obligatory marking should be introduced will be determined as per results of an experiment on certain milk products being marked with identification means; the list of such products has been fixed by the RF Government Order issued on June 29, 2019 No. 836.

The RF Government regulation dated June 14, 2019 No. 761 "On the RF Government regulation issued on October 7, 2016, No. 1019 becoming invalid"

The RF Government has withdrawn validity of the Technical Regulations on safety of chemical products which, according to the RF Government regulation issued on October 7, 2016, No. 1019, were to become valid on July 01, 2021. Starting from June 02, 2021, the Technical Regulations on the Eurasian Economic Union "On safety of chemical products" (EAEU TR 041/2017) come into force; the EAEU TR 041/2017 were approved by the EEC Council Decision on March 03, 2017 No.19.

The RF Government regulation dated June 22, 2019 No. 790 "On performing an experiment on certain light industry products being marked with identification means on the RF territory"

From June 27 till November 302019 an experiment is to be performed on the RF territory; during the experiment certain light industry products are going to be marked with identification means.
The list of such products includes pieces of clothing made of natural or composite skin; blouses and jumpers made of knitted fabrics; coats, short coats, capes, jackets (including ski costumes), windbreakers, and similar wear; bed linen; table cloths; kitchen towels and napkins. Among other things, the experiment is aimed at suppressing illegal imports, manufacture, and distribution of light industry products as well as raising volumes of collected customs and tax payments; participants in the experiment will provide initial data into a sub-system of the national catalogue that contains marked goods and is a part of the informational system for monitoring over goods distributed in the RF.

The RF Government regulation dated June 26, 2019 No. 814 "On performing an experiment on perfumes and toilet waters being marked with identification means on the RF territory"

From July 01, 2019 till November 30, 2019 an experiment is to be performed on the RF territory; during the experiment perfumes and toilet waters are going to be marked with identification means. The experiment is aimed at suppressing illegal imports, manufacture, and distribution of perfumes and toilet waters, including counterfeit ones, as well as raising volumes of collected taxes and customs payments. Participants in the experiment will provide initial data into a sub-system of the national catalogue that contains marked goods and is a part of the informational system for monitoring over perfumes and toilet waters distributed in the RF.

The RF Government regulation dated June 29, 2019 No. 836 "On performing an experiment on certain milk products being marked with identification means on the RF territory"

From July 15, 2019 till February 29, 2020 an experiment is to be performed on the RF territory; during the experiment certain milk products are going to be marked with identification means. The list of such products include those made of pasteurized milk, ultra-pasteurized milk, sterilized milk, and ultra-heat treated milk and (or) pasteurized, ultra-pasteurized, sterilized, and ultra-heat treated milk products manufactured via mass production and packed in consumer package.

Among other things, the experiment is aimed at suppressing illegal imports, manufacture, and distribution of certain milk products, including counterfeit ones, as well as at raising volumes of collected taxes and customs payments; another goal is to analyze whether it is advisable to introduce 
obligatory marking with identification means for certain milk products; it is also vital to assess efficiency of the "milk products" brunch component in the state system for monitoring over goods that are subject to obligatory marking.

"The list of federal executive authorities responsible for legal regulation in the sphere of state control (surveillance), and federal executive authorities that perform control and surveillance and participate in implementing "regulatory guillotine" mechanism; types of state control (surveillance) performed by federal executive authorities which are to be covered by the "regulatory guillotine" mechanism (approved by the RF Government on July 04, 2019)"

The list of state authorities that are to be involved into the "regulatory guillotine" mechanism has been approved. The "regulatory guillotine" mechanism should allow solving an issue related to excessive loads imposed on businesses in Russia by control and surveillance authorities. The list includes ministries and federal services (including Ministry for Internal Affairs, RF Ministry of Emergency Situations, Ministry of Justice, Ministry of Labor, Ministry of Digital Development, Communications and Mass Media, Rospotrebnadzor, Rostechnadzor, Rosobrnadzor, and federal AntiMonopoly Agency); all these federal authorities perform legal regulatory functions in the sphere of state control (surveillance) as well as direct control and surveillance activities. The RF Government has also approved on "The action plan on implementing the "regulatory guillotine" mechanism on May 29, 2019, No 4714p-P36). The document fixes the procedure for implementing the "regulatory guillotine" mechanism.

The RF Government regulation dated July 13, 2019 No. 895 "On making amendments into certain orders by the RF Government"

Rospotrebnadzor is now authorized to perform surveillance and control over adherence to the obligatory requirements fixed in the RF legislation as regards providing high quality and safety of food products. It has also been specified that federal state surveillance related to consumer rights protection should, among other things, include organizing and accomplishing inspections aimed at checking conformity of goods (works, services) with the obligatory requirements that are to provide quality and safety of food products, as well as materials or other objects that directly contact them.
The RF Government regulation dated August 24, 2019 No. 1089 "On introducing temporary quantitative restriction on imports of ozone-depleting substances into the Russian Federation in 2019"

From September 07, 2019 till December 31, 2019 quantitative restriction is imposed on imports of certain ozone depleting substances into the RF. Restrictions are imposed on ozone-depleting substances that are enlisted in the group I, list C. section 2.1 in the list of goods for which an import license is required when they are imported onto the EAEU customs territory, or an export license when they are exported out of this territory; the list can be found in Appendix No. 2 to the Decision by the EEC Council dated April 21, 2015 No. 30 "On non-tariff regulation", according to the appendix to the above RF Government regulation.

The RF Government regulation dated August 28, 2019 No. 1906-r "On approving a plan of activities aimed at implementing The Basics of the RF state policy in the sphere of providing chemical and biological safety for the period up to 2025 and beyond"

The document fixes a set of activities necessary for providing biological and chemical safety in the RF for the period up to 2025 and beyond. Among other things, the set includes the following activities: preparing a draft of a federal law entitled "On biological safety in the Russian Federation", as well as legal documents necessary for its implementation; preparing a draft of a federal law "On chemical safety in the Russian Federation" as well as legal documents necessary for its implementation; preparing a draft of a federal law "On industrial safety" (new edition) that should stipulate a procedure for performing audit over industrial safety control at chemically hazardous industrial objects; making alterations into the Federal Law "On licensing of certain activities" and revising lists of goods and technologies that are subject to control approved by the RF President Order on August 28, 2001 No. 1082; The RF accession to international treaties on cross-border movement of genetically modified organisms; etc.

The Information Letter by Rospotrebnadzor from July 01, 2019 "Recommendations on how to place milk products, products made of milk raw materials and products containing milk on shelves at sales points"

Rospotrebnadzor reminds that starting from July 01, 2019 the RF Government Regulation is- 
sued on January 28, 2019 No. 50 has come into force; among other things, this Regulation makes it obligatory to place milk products, products made of milk raw materials or products that contain milk in a sales area or any other place where such products can be bought in such a manner that allows visual distinguishing between them and other food products. Also these products are to be provided with information stating "Products that do not contain any substitutes of milk fats".

On June 18, 2019 Rospotrebnadzor and the RF Ministry of Industry and Trade jointly issued the Order No. 368/2098 "On Approval on methodical guidelines as regards recommended ways to place milk products, products made of milk raw materials and products that contain milk in a sales area or any other place where such products can be bought and their placement should allow visual distinguishing between such products and other food products as well as recommended ways on how to provide such products with information stating "Products that do not contain any substitutes of milk fats" (hereinafter called The Guidelines). The Guidelines will allow securing a consumer's right to obtain necessary reliable information on goods; this right is protected by statements fixed in Clause 8 of the RF Federal Law issued on February 07, 1992 No. 2300-1 "On consumer rights protection".

The Information Letter by Rospotrebnadzor "On possibility to apply national legislation on consumer rights protection to purchases made on foreign online shopping sites"

Rospotrebnadzor informs that national legislation on consumer rights protection can be applied in situations when purchases are made on foreign online shopping sites. Rospotrebnadzor informs that the Resolution "On applying regulations of international private law by courts in the Russian Federation" by the RF Supreme Court Plenum dated July 09, 2019 No. 24 has been published on the RF Supreme Court official web-site; the Resolution clarifies what legal norms courts in the RF are to be guided by when investigating cases of Russian consumers suing foreign online shopping sites or online sites that render cross-border services.

Specifically, a consumer who applies to a Russian court is released from paying a state due (for suits with their sum being lower than 1 million rubles), and a seller is to be fined for failing to voluntarily meet legitimate demands of a customer; an online shopping site can be considered as oriented at Russian consumers provided that Russian language is available on it, prices are given in Russian rubles, there are contact numbers with Russian phone codes or there are any other similar indications (for example, a site's owner has ordered some services that could raise citing of it in the Russian segment of the Internet); a court on its own initiative is entitled to secure consumer's rights protection granted by imperative norms fixed in a law of a country where a consumer lives.

The Letter by Rospotrebnadzor dated May 21, 2019 No. 02/7115-2019-23 “On a procedure for assessing conformity of products"

The Letter clarifies peculiarities related to assessing conformity of products classified in EAEU CN FEA with codes 3901-3911 and aimed for use in communal and drinking water supply or in food products manufacture. In particular, it is stated that raw materials and active reactants that are to be used exclusively for producing perfumes, cosmetics, household chemical goods, plant protectors, disinfectants, means of disinsection and deratization as we'll as pharmaceutical products are not subject to state registration.

State registration is obligatory for products classified in EAEU CN FEA with codes 3901-3911, specifically, for goods that are applied in communal and drinking water supply or in food products manufacturing, in cases when their manufacturers rank them among products listed in items 8-9 of Clause II: "Materials, equipment, devices, or any other tools for water treatment applied in communal and drinking water supply systems (item 9) or potentially hazardous chemical and biological substances and preparations made of such substances... (item 8)".

"Methodical guidelines on how to use mobile communications means in educational establishments" MG 2.4.0150-19 (approved by Rospotrebnadzor on August 14, 2019 No. 01-230/13-01)

Among other things, the document recommends:

- imposing limitations on use of mobile phones by schoolchildren during educational process;

- ensuring all mobile phones being switched into "silent mode" when their owners enter a school (vibration mode should be excluded);

- providing places where schoolchildren can leave their mobile phones to be stored during classes (in case of necessity);

- accomplishing regular educational and explanatory work on health risks caused by exposure to electromagnetic radiation generated by mobile phones. 
Rospotrebnadzor is going to issue instructions for schoolchildren, parents, and teachers on how to prevent effects produced by mobile phones that are hazardous for children's health and education.

The Order by the RF Ministry of Natural Resources and the Environment dated June 06, 2019 No. 355 "On Approval of a regulatory document on environmental protection headed "Technological parameters to assess the best available technologies for food products manufacturing"

The document fixes technological parameters that should be taken into account when assessing a technology:

- emissions into the atmosphere, notably, particulate matter, ammonia, methane, acetone, lead and its compounds, and hydrogen sulphide, that occur at productions of meat and meat-containing canned food, sausages and delicatessen, semicooked products, processing and preserving fruits and vegetables, manufacture of tins for canned fruits and vegetables, manufacture of specific fats, margarine, and spreads, sugar manufacture;

-discharges into water objects, including particulate matter, iron, phenol, phosphates, and oil products.
State Standard ISO/IEC 17025-2019. Interstate Standard. "General requirements for the competence of testing and calibration laboratories (effected by the Order of the Federal Agency for Technical regulating and Metrology dated July 15, 2019 No. 385-st)

The Interstate Standard ISO/IEC 17025-2019 "General requirements for the competence of testing and calibration laboratories" has come into force on September 01, 2019 and is now considered a national standard in the RF.

The Standard replaced the previous one, GOST ISO/MEK 17025-2009 and is identical to the international standard ISO/IEC 17025:2017 "General requirements for the competence of testing and calibration laboratories", IDT.

The Standard fixes general requirements for the competence, objectivity, and stable functioning of laboratories; it can be applied to all the organizations that are involved into laboratory activities regardless of their staff number.

Customers who apply to laboratories, regulatory bodies, organizations and those who use parity assessment, accreditation institutions, as well as any other concerned parties should apply the present Standard when certifying or acknowledging competence of a laboratory. 